\title{
The impact of mammalian insectivores Rattus rattus (Rat), Mus musculus (Mouse) \& Erinaceus europeus (Hedgehog) on the size and abundance of mainland Coleoptera and Orthoptera
}

\author{
By
}

Thomas William Hewitt

A thesis submitted to the Victoria University of Wellington in fulfilment of the requirements of the degree Master of Science in Ecological Restoration

Victoria University of Wellington

(2021) 


\section{Abstract}

The impact of introduced mammalian predators on indigenous vertebrates is relatively well documented, however the general responses of indigenous invertebrate communities is less well known. Many indigenous invertebrates, particularly the large flightless species such as those in the genus Deinacrida (Orthoptera) and Anagotus (Curculionidae) have been extirpated from much of their range due largely to the impacts of introduced predators. Despite these wellknown examples very little is known about the general impact of introduced predators on invertebrate communities. Beginning in 2012 pitfall traps and artificial wētā motels were established across seven study sites in the Aorangi and Remutaka ranges east of Wellington alternately baited with squid and monitored two to three times annually. Mammal tracking took place in the form of tracking tunnels giving three mammal indexes for rats (Rattus rattus), mice (Mus musculus) and hedgehogs (Erinaceus europeus). Cavity dwelling wētā in wêtā motels were measured and counted in situ whilst pitfall trapped Coleoptera and Orthoptera were transported to the lab for measuring and identification. Linear mixed effects model, type 3 ANOVAS and generalised linear mixed models were used to examine whether mammal index had any impact on the size and the catch or occupancy of invertebrates. Increased rat and mouse tracking was associated with reduced coleoptera catch whilst increased hedgehog tracking was correlated with increases in Coleoptera catch. Pitfall trapped wētā (Hemiandrus spp) showed strong negative responses to increased rat tracking, neutral responses to mice and positive responses to hedgehogs. Tree wētā (Hemideina crassidens) occupancy rates declined in response to increased mouse abundance whilst the mean size of tree wêtā residing in wētā motels showed an increase in response to rats and mice. These results show the complexity of understanding mammal invertebrate interactions which cannot be expected to be the same in all environments or across all taxa. Environmental factors typically impact far more strongly on invertebrate populations than they do on vertebrates and can obscure the impacts of top down predation in such studies. The results reported in this study only became apparent after $5+$ years of sampling, demonstrating the importance of long-term temporal analysis of invertebrate communities in response to mammals before trends start to emerge. More research is required into the basic ecology and population dynamics of invertebrate communities before more general trends can be discerned. 


\section{Acknowledgements}

I would first like to thank my supervisor Stephen Hartley for taking me on and for encouraging me to peruse this area of research. I have learned so much over the course of writing this thesis and have a new appreciation for the diversity of invertebrate life in New Zealand. Your patience in providing feedback, encouragement and enthusiasm for this project has been hugely motivating and greatly appreciated.

Thank you to Olivia Vergara whose work laid the foundations for this project and whose beetle collections I relied on heavily. Thank you to Dave Seldon from the University of Auckland for confirming our carabid beetle identifications and to all those who contributed to my inaturalist page, Stephen Thorpe, Samuel Brown and others. These invertebrate identifications have been extremely helpful.

A special thanks to Nyree Fea for help with the mammal tracking data, with $\mathrm{R}$ and for all the organisation for the Aorangi project. Thank you to Ellen Carlyon and Tom Anderson for showing me how to sort the invertebrate specimens and for all your hard work on the Aorangi project. Thank you to all the students past and present who have participated assisted in the Aorangi project and without whom this research would not have been possible. To everyone in Stephen Hartley's lab group Lena Aeberli, Henry Morse, Cameron Johnson, Nyree Fea, Tom Dawes \& Ellen Carlyon thank you for all the feedback over these past 12 months.

Lastly, I would like to thank my parents Andrew and Sarah and my sister Phoebe for supporting me over the past year and for encouraging me to peruse my interests. I couldn't have done this without you. 


\section{Table of Contents}

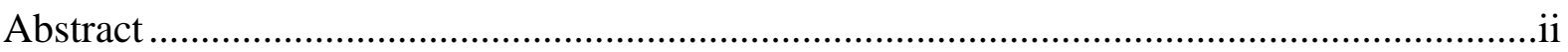

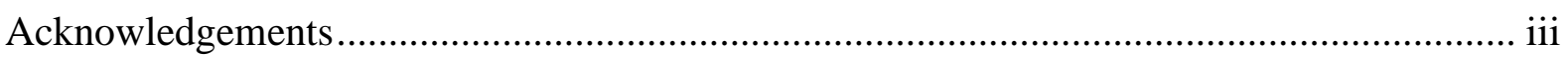

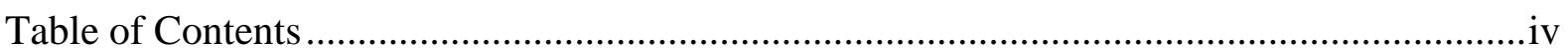

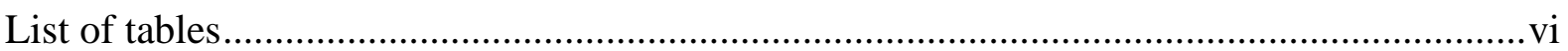

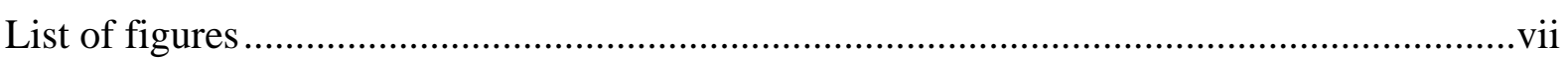

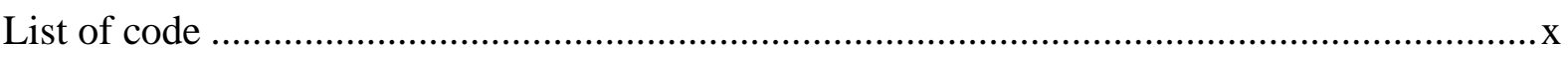

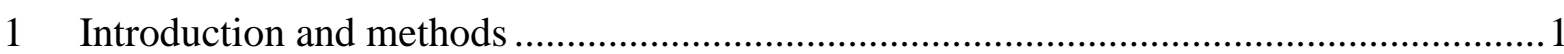

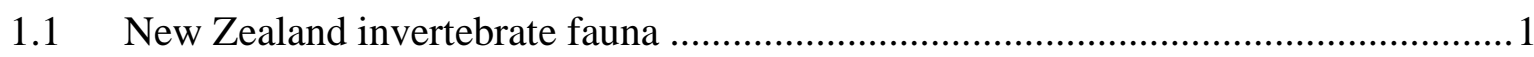

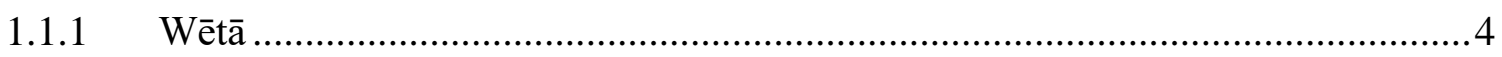

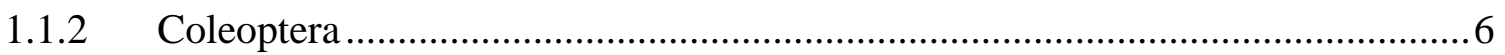

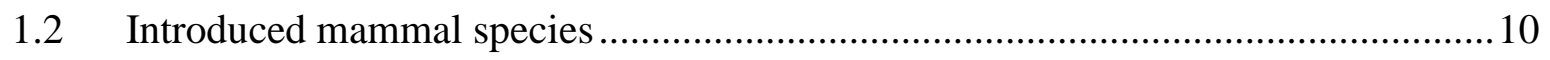

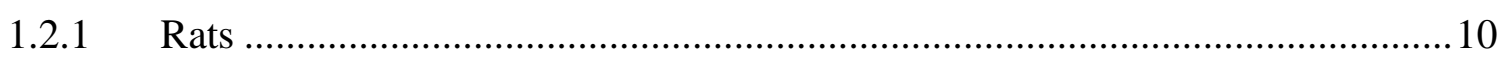

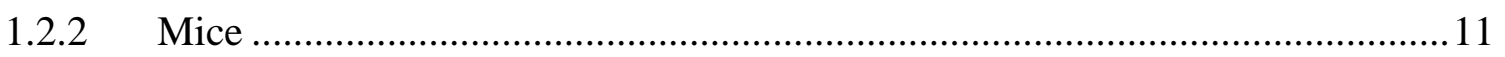

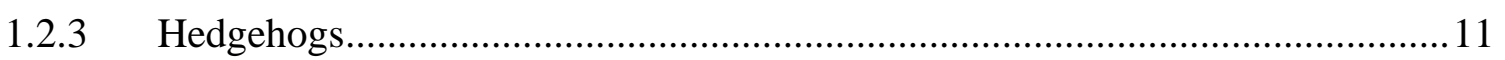

1.3 Beech masts and mammal population dynamics................................................... 11

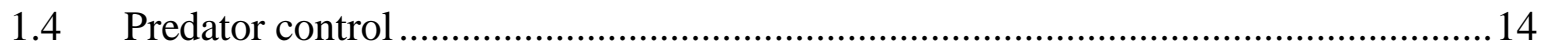

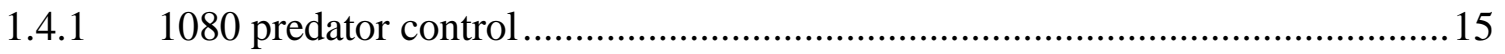

1.4.2 Indirect effects of mammals on invertebrates ................................................ 16

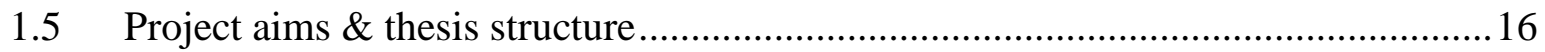

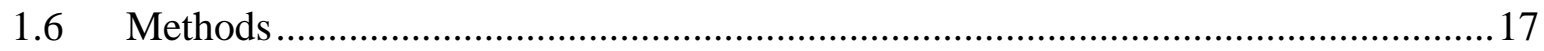

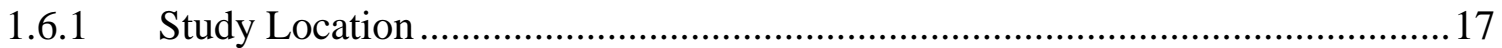

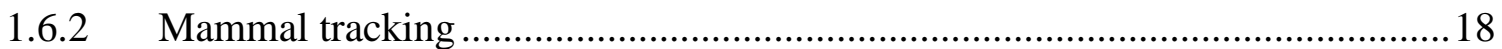

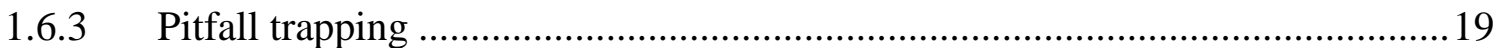

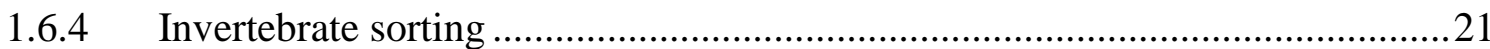

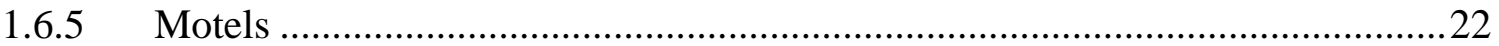

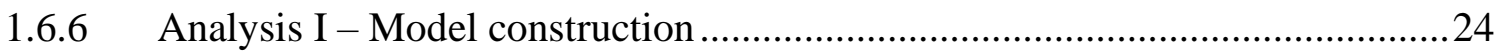

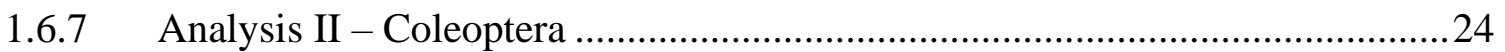

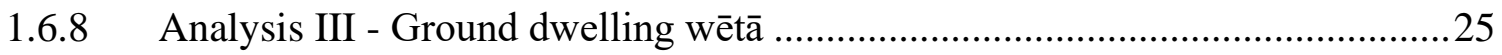

1.6.9 Analysis IV - Cavity dwelling wētā...............................................................2 25

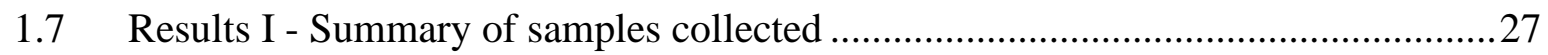

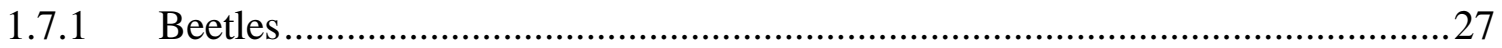

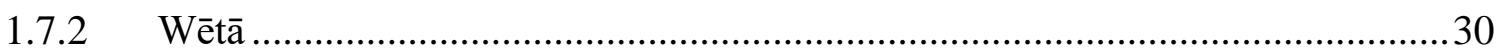

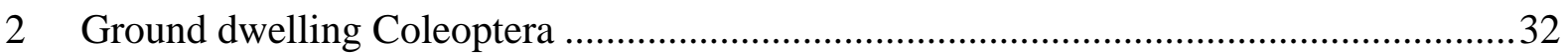




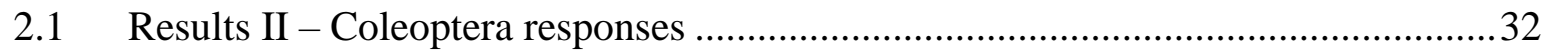

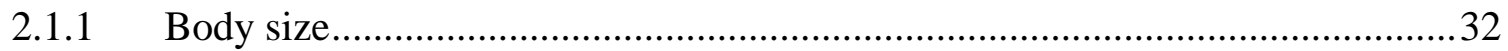

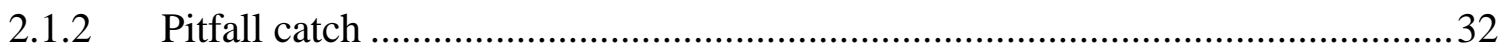

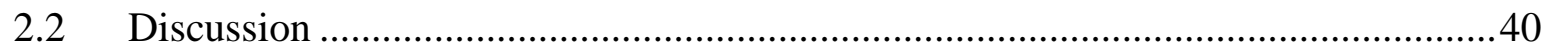

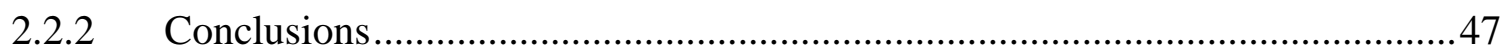

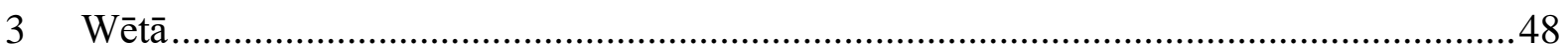

3.1 Results III - Ground dwelling wētā ............................................................. 48

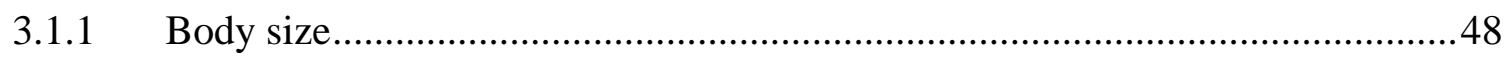

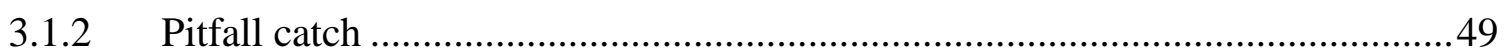

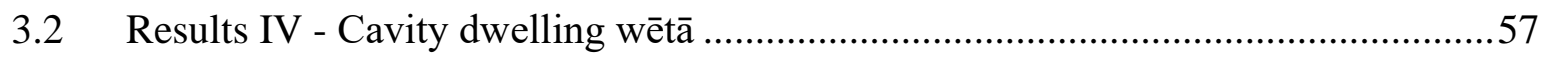

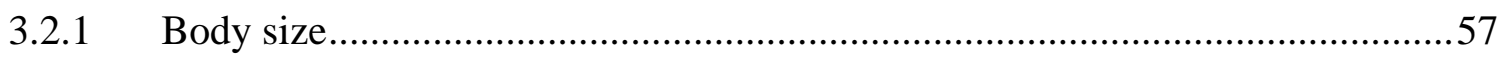

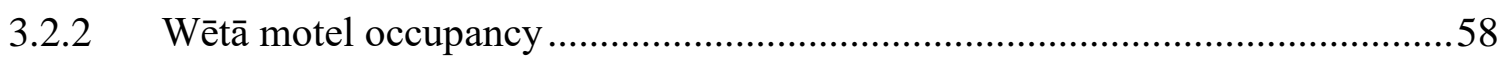

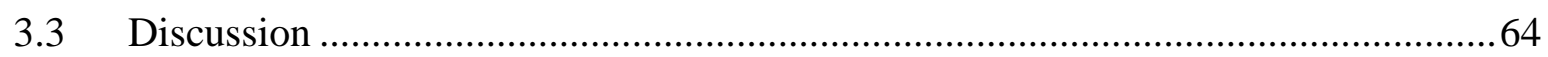

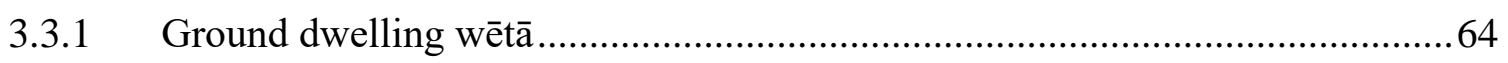

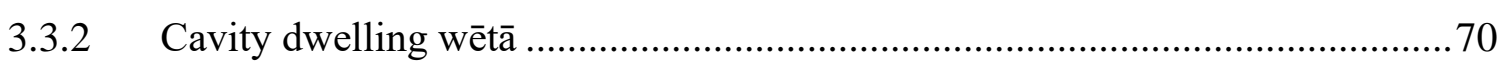

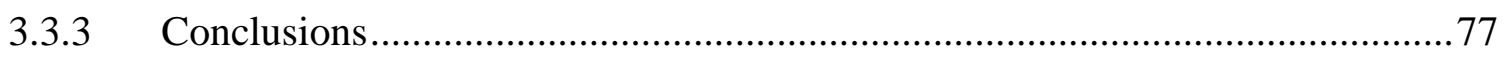

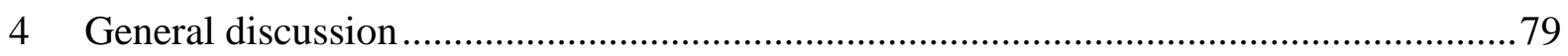

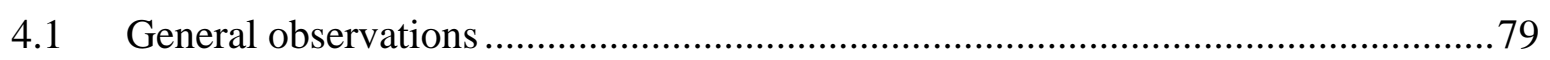

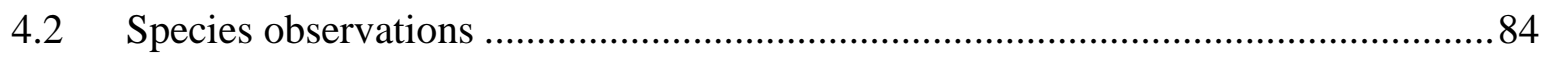

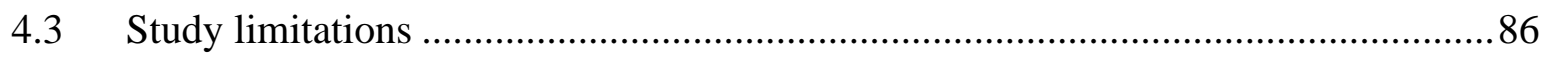

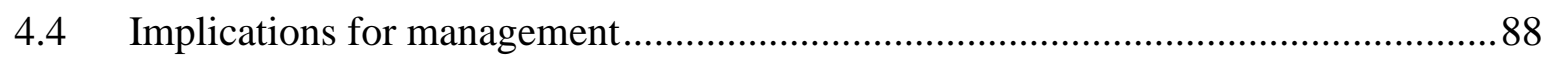

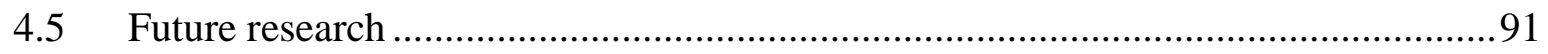

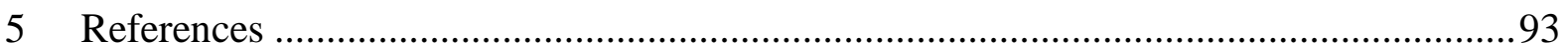

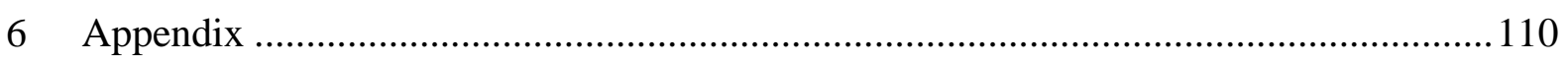




\section{List of tables}

Table 1.1 Introduced mammalian insect predators in New Zealand ...................................... 14

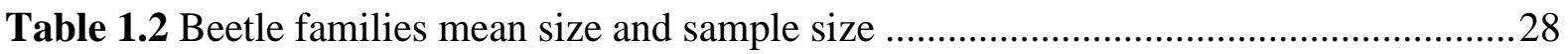

Table 1.3 Ground dwelling wētā mean size and sample size............................................... 30

Table 1.4 Cavity dwelling wētā mean size and sample size ...............................................31

Table 2.1 Model estimates for beetle size and mammal index. …........................................ 34

Table 2.2 Model estimates for beetle catch and mammal index ..........................................34

Table 3.1 Model estimates for ground dwelling wētā size and mammal index .....................50

Table 3.2 Model estimates for ground dwelling wētā catch and mammal index...................51

Table 3.3 Model estimates for cavity dwelling wētā size and mammal index.......................59

Table 3.4 Model estimates for cavity dwelling wētā occupancy and mammal index.............60

Table 6.1 Pitfall trapped weta catch in the Aorangi and Remutaka forests .........................111

Table 6.2 Coleoptera species list in the Aorangi and Remutaka forests ............................ 111

Table 6.3 Model estimates for beetle size and mammal index (All families).......................114

Table 6.4 Model estimates for beetle catch and mammal index (All families) ....................115

Table 6.5 Correlation matrix for mammal tracking index calculated for site and season..... 116 


\section{List of figures}

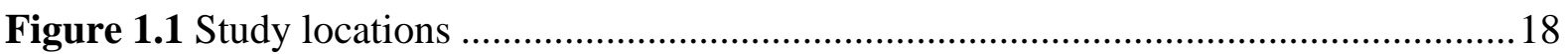

Figure 1.2 Positioning of pitfall traps along monitoring lines ...........................................20

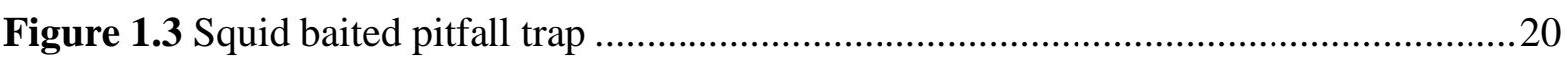

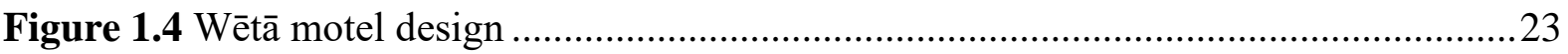

Figure 1.5 Carabidae and Scarabaeidae caught in pitfall traps ...........................................29

Figure 1.6 Staphylinidae and other beetles caught in pitfall traps .....................................29

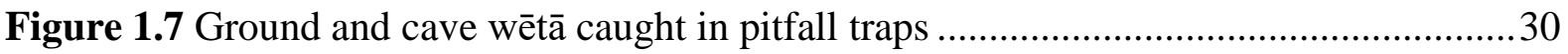

Figure 2.1 Carabidae size hedgehog index by season and squid baiting ...............................35

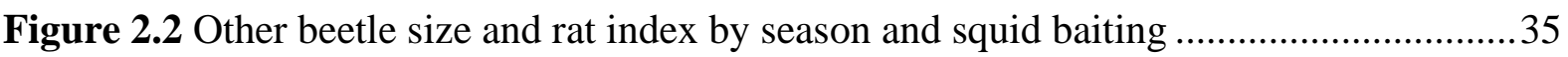

Figure 2.3 Scarabaeidae size and mouse index by season and squid baiting......................... 36

Figure 2.4 Scarabaeidae size and hedgehog index by season and squid baiting .................... 36

Figure 2.5 Rat index and beetle pitfall catch by family ..................................................... 37

Figure 2.6 Mouse index and beetle pitfall catch by family................................................ 37

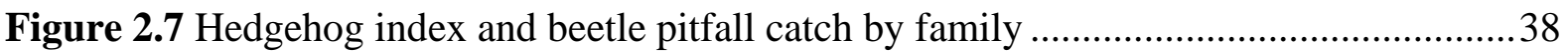

Figure 2.8 Rat index in the previous season and beetle pitfall catch by family......................38

Figure 2.9 Mouse index in the previous season and beetle pitfall catch by family ................39

Figure 2.10 Hedgehog index in the previous season and beetle pitfall catch by family......... 39

Figure 3.1 Cave wētā size and rat index by season and squid baiting .................................52

Figure 3.2 Male ground wētā size and mouse index by season and squid baiting..................52

Figure 3.3 Cave wētā size and mouse index in the previous seson by season and squid baiting.

Figure 3.4 Cave wētā size and mouse indec in the previous season by season and squid baiting

Figure 3.5 Male ground wētā size and mouse index in the previous season by season and squid baiting.....

Figure 3.6 Rat index and wētā pitfall catch by group ........................................................54

Figure 3.7 Mouse inde and wētā pitfall catch by group...................................................55

Figure 3.8 Hedgehog index and wētā pitfall catch by group ..............................................55

Figure 3.9 Rat index in the previous season and wētā pitfall cach by group.........................56

Figure 3.10 Mouse index in the previous season and wētā pitfall catch by group .................56

Figure 3.11 Female tree wētā size and rat index by sampling season .................................57 
Figure 3.12 Female tree wētā size and rat index by sampling season .61

Figure 3.13 Rat index and wētā motel occupancy by group ............................................61

Figure 3.14 Mouse index and wētā motel occupancy by group..........................................62

Figure 3.15 Hedgehog index and wētā motel occupancy by group ....................................62

Figure 3.16 Rat index in the previous season and wētā motel occupancy by group ............63

Figure 3.17 Mouse index in the previous season and wētā motel occupancy by group .........63

Figure 3.18 Hedgehog index in the previous season and motel occupacny by group ............64

Figure 6.1 Mammal index in the Aorangi forest park including the timing of 1080 pest control operations and beech masting events.

Figure 6.2 Mammal index in the Remutaka forest by season including the timing of 1080 aerial pest control and timing of beech masts

Figure 6.3 Mean beetle size and rat index in the Aorangi forest park by season ................118

Figure 6.4 Mean beetle size and rat index in the Remutaka forest park by season .............118

Figure 6.5 Mean beetle size and mouse index in the Aorangi forest park by season ........... 119

Figure 6.6 Mean beetle size and mouse index in the Remutaka forest park by season ........ 119

Figure 6.7 Mean beetle size and hedgehog index in the Aorangi forest park by season ...... 120

Figure 6.8 Mean beetle size and hedgehog index in the Remutaka forest park by season ... 120

Figure 6.9 Mean beetle catch and rat index in the Aorangi forest park by season ...............121

Figure 6.10 Mean beetle catch and rat index in the Remutaka forest park by season .......... 121

Figure 6.11 Mean beetle catch and mouse index in the Aorangi forest park by season....... 122

Figure 6.12 Mean beetle catch and mouse index in the Remutaka forest park by season.... 122

Figure 6.13 Mean beetle catch and hedgehog index by season in the Aorangi forest park .. 123

Figure 6.14 Mean beetle catch and hedgehog index by season in the Remutaka forest park

Figure 6.15 Pitfall trapped wētā size and rat index by season ......................................... 124

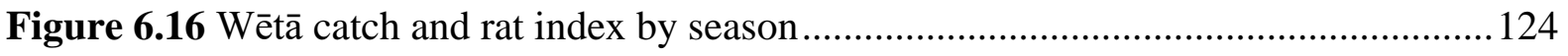

Figure 6.17 Pitfall trapped wētā size and mouse index by season .................................... 125

Figure 6.18 Wētā catch and mouse index by season ..................................................... 125

Figure 6.19 Pitfall trapped wētā size and hedgehog index by season................................. 126

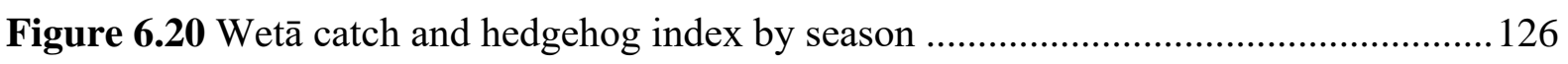

Figure 6.21 Cavity dwelling wētā size and rat index by season ...................................... 127

Figure 6.22 Wētā motel occupancy and rat index by season ........................................... 127

Figure 6.23 Cavity dwelling wētā size and mouse index by season ................................... 128

Figure 6.24 Wētā motel occupancy and mouse index by season ....................................... 128 
Figure 6.25 Cavity dwelling wētā size and hedgehog index by season .............................129

Figure 6.26 Wētā motel occupancy and hedgehog index by season...................................129 


\section{List of code}

Box 1.1 R code for pitfall size model, significance testing and $\mathrm{R}^{2}$ calculations .....................26

Box 1.2 $R$ code for pitfall abundance models, significance testing and $R^{2}$ calculations .........26

Box 1.3 $\mathrm{R}$ code for tree wētā size model, significance testing and $\mathrm{R}^{2}$ calculations ...............26

Box 1.4 $\mathrm{R}$ code for tree wētā occupancy model, significance testing and $\mathrm{R}^{2}$ calculations .....27 


\section{Introduction and methods}

\subsection{New Zealand invertebrate fauna}

Invertebrates account for a huge portion of earth's total biodiversity with some estimates suggesting there may be as many as 13.5 million species of insects and terrestrial arthropods (Stork, 2018). These species are responsible for providing many important ecological functions such as decomposition, nutrient cycling, pollination and are an important food source for other taxa (Ward \& Larivière, 2004). Despite the immense diversity and perceived importance of these species very little is known about the current state of invertebrate communities and how they have responded to human induced changes in the environment, such as habitat loss and invasive species. Reports from many localities have indicated an overall decline in invertebrate species diversity but these studies have tended to focus on a limited number of taxa in a few locations and may not be representative of broader trends (Cardoso \& Leather, 2019; Dornelas \& Daskalova, 2020; Leather, 2017; Saunders et al., 2020). Overall, there is a dearth of knowledge around the life histories and identities of most invertebrate species on earth and very few studies have been able to accurately describe the drivers and scale of change these communities.

New Zealand has been isolated from all other major landmasses for roughly 80 million years since it separated from the supercontinent of Gondwanaland. This has meant a unique evolutionary trajectory for New Zealand's plants and animals leading to a high level of endemism amongst its flora and fauna, estimated at between $80-90 \%$ for most faunal groups (McGuinness, 2007). Crucially, New Zealand was not home to any native land mammals, apart from three species of bat (Mystacina spp), prior to the arrival of humans roughly 900 years ago (McGuinness, 2007). The first mammals to arrive in New Zealand with human settlers were species such as the Kiore (Rattus exulans), and the kuri or māori dog (Canis familiaris) which arrived from Polynesia. Further arrivals such as ship rats (Rattus rattus), possums (Trichosurus vulpecula), hedgehogs (Erinaceus europaeus) and mice (Mus musculus) arrived later with European settlement in the $18^{\text {th }}, 19^{\text {th }}$ and early $20^{\text {th }}$ centuries.

One of the defining features of isolated island invertebrate communities is a greater relative abundance of large species relative to similar continental invertebrate communities, a phenomenon referred to as island gigantism. This phenomenon is often thought to be a response 
to reduced predation pressure on islands which typically support fewer species of carnivorous mammals and therefore there is less of an advantage to small species in terms of predator avoidance (Holwell \& Andrew, 2015). This increased size is thought to make many invertebrate taxa in New Zealand particularly susceptible to mammalian predation and extinction. Many of New Zealand's most well-known and largest invertebrate species are known to have suffered declines as a result of direct predation caused by the introduction of introduced mammals some notable examples include the Mercury Island tusked wētā (Motuwètà isolata), Powelliphanta land snails and some large native weevils such as those in the genus Anagotus (Kuschel \& Worthy, 1996; Miskelly et al., 2018; Stringer et al., 2014; Walker, 2003). Despite this, the general impact of introduced mammals on the size distribution of the more common species of indigenous invertebrates is not well known. If size is a factor which determines the vulnerability of native invertebrates, then it would be expected that larger individuals of a species or taxonomic group would become relatively less common in invertebrate populations after a boom of insectivorous mammals.

Despite the hypothesised increased vulnerability of larger invertebrate taxa to introduced mammals, several relatively large taxa have persisted and remain relatively common even in locations where mammals persist. One of the most notable examples are tree wētā in the genus Hemideina, these nocturnal, arboreal cavity dwelling species $(\sim 40 \mathrm{~mm})$ are widespread throughout the country suggesting that size is unlikely to be the only factor increasing the vulnerability of island invertebrates to invasive species (Gibbs, 1998; Rufaut \& Gibbs, 2003).

Other traits characteristic of New Zealand invertebrates include, longer life spans, flightlessness and a tendency towards ground dwelling nocturnal behaviour (Gibbs, 2009). Some of these traits are thought to have made them particularly susceptible to predation from introduced mammalian predators such as rats, mice and hedgehogs. Whilst mammalian predators typically hunt using olfactory cues indigenous predators such as native birds are thought to primarily use sight. This difference in hunting strategies between mammalian and primarily avian predators suggests that indigenous New Zealand invertebrates would not have adapted predator avoidance strategies suitable for avoiding mammalian predators and therefore are likely highly vulnerable to predation (Castro et al., 2010; Gibbs, 2010).

As with invertebrate communities in most regions of the world, relatively little is known about the general population trends of most of New Zealand's invertebrate species, making it difficult to determine the conservation status and major threats faced by invertebrate communities 
(Dornelas \& Daskalova, 2020; Lester et al., 2014). In addition, the importance of interactions between New Zealand's invertebrates and mammalian predators is yet to be quantified apart from for a few well-studied invertebrate species such as giant wētā in the genera Deinacrida and Motuwètā and some large weevil species (Kuschel \& Worthy, 1996; Miskelly et al., 2018; Watts \& Thornburrow, 2009; Winks et al., 1998). A lack of knowledge of invertebrate life histories and the high level of taxonomic expertise required to correctly identify invertebrate species has hampered efforts in this area (Carpenter et al., 2016). It is likely that among New Zealand's invertebrate fauna some species will have been adversely affected whilst some may have benefitted however, the identity of all but a small proportion of these species remains unknown (Stringer \& Hitchmough, 2012; Watts et al., 2019).

Seven invertebrate species are known to have gone extinct in New Zealand according to the New Zealand Threat Classification database (NZTCS) which evaluated 3838 species (Stringer \& Hitchmough, 2012), however the number of invertebrate extinctions in New Zealand following human settlement is likely much higher due to likelihood of cryptic extinctions (Gibbs, 2009). Of the 3838 species evaluated in the NZTC, 1208 were classed as data deficient, meaning that reliable information on how to classify these organisms was not available. Estimates vary as to the total number of invertebrate species found in New Zealand, but it is thought that around 11,000 species of terrestrial invertebrates have been described and at least as many more are thought to remain undocumented. This is a global phenomenon often referred to as "the taxonomic impediment" where a high proportion of species remain undescribed (Ward \& Larivière, 2004). This demonstrates the gap in current knowledge about the present invertebrate fauna in New Zealand and the difficulty in assessing how invertebrate communities have changed with the arrival of mammalian predators.

Despite a lack of knowledge on the responses to predation by introduced mammals, negative effects of invasive mammalian predators on invertebrate diversity in New Zealand have been documented for some invertebrate taxa. It is thought that mammalian predation presents one of the most significant threats to invertebrate diversity in New Zealand and invertebrates are known to constitute a large portion of the total diet of many introduced mammal species (Lester et al., 2014; Miller \& Miller, 1995) and that this has likely had an impact on the structure and functioning of invertebrate communities relative to their pre mammal state. For instance, Rattus rattus (ship rats) have been estimated to consume roughly $10 \mathrm{~g}$ animal $^{-1}$ night $^{-1}$, mice $2 \mathrm{~g}_{\text {animal }}{ }^{-}$ ${ }^{1}$ night $^{-1}$ and Erinaceus europeus (European hedgehog) $120 \mathrm{~g} \mathrm{animal}^{-1}$ night $^{-1}$ in some New Zealand forests (Innes et al., 2010). 
One of the main effects of mammal predation on indigenous invertebrate communities appears to be a reduction in the numbers of larger-bodied organisms. Genera such as Deinacrida (giant wētā), Motuwētāa, Anisoura (Tusked wētā), Powelliphanta (Land snails), Chilopoda (giant centipedes) and Diplopoda (giant millipedes) are some of the most well-known examples all of which have declined or been eliminated from much of their former range (Ruscoe et al., 2013). In addition, the adult and large female forms of many invertebrates are thought to be more heavily impacted by mammal predation than the smaller males and juveniles (Watts et al., 2011).

\subsubsection{Wētā}

In New Zealand, wētā refers to several native Orthopteran in the families Anostostomatidae and Rhaphidophoridae. Within Anostostomitidae there are four main groups consisting of the genera: Deinacrida (giant wētā), Hemideina (tree wētā), Hemiandrus (ground wētā) and Motuwètā \& Anisoura (tusked wētā). Wētā represent some of the best studied of New Zealand's invertebrates however there are still major knowledge gaps regarding the precise taxonomy and life histories of some species within these groups (Trewick et al., 2020). Species within the family Rhaphidophoridae are collectively referred to cave wētā which is a more specious and less well described group, there are currently around 55 described species in 16 genera but more likely exist (Fitness et al., 2015; Watts et al., 2011). Wêtā are mostly though to be omnivorous and make use of a range of resources including seeds, fruit, leaves, invertebrates and carrion suggesting some species may occupy a similar niche to that of mice (Brown, 2013; Griffin, Morgan-Richards, et al., 2011). Wētā species of multiple genera are found across a range of habitats but are most common in arboreal environments in both native and exotic forests (Fitness et al., 2015; Watts et al., 2017).

Deinacrida are mostly confined to areas of native forest and scrub where mammals have been eradicated such as fenced ecosancturies and pest free islands. One notable exception is Deinacrida mahoenui or the Mahoenui giant wētā which has persisted on the North Island of New Zealand in spite of mammal predation by making use of the refuge provided by the thorns of introduced Ulex europeus (Gorse) thickets which are thought to deter mammals (Watts \& Thornburrow, 2009). However, even this species is thought to be in steady decline on the mainland (Stilborn, 2019). The effect of habitat refugia provided by different types of forest habitat has not been extensively studied in other invertebrate taxa. It is possible that other wētā 
species, specifically tree wētā, may also benefit from the habitat refuge provided by gorse thickets.

Despite reported declines in many forested areas associated with mammal predation, wētā in the genera Hemideina, Hemiandrus and the family Rhaphalidophoridae are still relatively common in forest habitats across New Zealand. This has led to them being proposed as ideal biodiversity indicators as they are relatively easy to identify (Watts et al., 2017). Each of these wētā groups occupy different niches in forest environments and a range of sampling techniques are required to record and study their occurrence.

Hemideina (tree wētā) are among the best studied of New Zealand's forest invertebrates consisting of seven easily distinguishable species (Watts et al., 2017). Tree wētā mostly live in arboreal forest environments where they occupy tree cavities, known as wētā galleries, during the day emerging at night to feed. These galleries are often controlled by a single male wētā who competes with other males for control over a harem of females. Analyses of the excretions of tree wêtā revealed a diet consisting mostly of fruits, seeds and leaves and some consumption of smaller invertebrates but tree wētā are known to opportunistically make use of live and dead animals (Griffin, Morgan-Richards, et al., 2011).

The construction of artificial tree cavities called wētà motels is often used to measure the abundance of tree wētā (Trewick \& Morgan-Richards, 2000). These are wooden boxes with holes drilled in the bottom to allow for wētā to enter and feature a hinged door with a piece of clear plastic which allows the wêtā to be viewed by researchers. This allows for nonlethal recording of wêtā abundance in the field however this method does have limitations and as with most invertebrate sampling methods caution must be utilised when using them to infer abundance (Bowie et al., 2014). There are many potential factors that may influence wētā motel occupancy beyond simple abundance, such as the availability of nearby tree cavities and behavioural differences caused by differences in predator abundance. The behaviour and habits of tree wētā are thought to change in response to the presence of mammalian predators with studies indicating that in the absence of mammals wētā do not venture as far from gallery entrances and occupy galleries closer to the ground (Bremner et al., 1989).

Hemiandrus (ground wētā) are smaller, nocturnal, mostly ground dwelling species of wētā ranging from 12 to $45 \mathrm{~mm}$ in length (Chappell, 2008). Ground wētā seal themselves in burrows during the daytime emerging to feed at night. In contrast to tree wētā, ground wētā primarily feed on other small forest invertebrates but can also make use of fruit and seeds. Hemiandrus 
is the most specious genera of the anostomatid wētā with around 17 described species, however potentially dozens more are yet to be formally identified (Taylor-Smith et al., 2016; Trewick, 2021). In the Aorangi and Remutaka ranges the vast majority of Hemiandrus belong to Hemiandrus pallitarsis with occasional records of Hemiandrus bilobatus and Hemindrus maculifrons reported in other studies (Moeed \& Meads, 1985; Trewick et al., 2020; Vergara, 2018; Vergara et al., 2020).

\subsubsection{Coleoptera}

Relative to native Orthoptera much less is known about life histories and vulnerability of New Zealand's Coleoptera despite receiving reasonable attention amongst entomologists. As with other invertebrate groups and New Zealand biota more generally Coleoptera display high levels of endemism estimated to be as much as $90 \%$ or greater in some families such as carabids (Lövei \& Cartellieri, 2000). It is estimated that there are over 5000 native and more than 340 introduced beetle species found in New Zealand with many yet to be described (McGuinness, 2007).

\subsubsection{Carabidae (ground beetles)}

Carabidae is a large diverse family of mostly carnivorous ground beetles. Carabids are found in a range of habitats across native forest, tussock grassland and exotic pine plantations, but little is known about their basic ecology, population dynamics or response to introduced mammalian predators (Berndt \& Brockerhoff, 2019; Berndt et al., 2008; Larochelle \& Larivière, 2001). Approximately 99 carabid genera have been described in New Zealand and there may be $>800$ species and subspecies of which 547 have been formally described. New Zealand carabids display high levels of endemism estimated at $93 \%$ of all native species and $62 \%$ of genera (Larochelle \& Larivière, 2013, 2016). New Zealand carabids are mostly flightless and nocturnal, both traits are likely legacies of historic predation by predominantly avian and reptilian predators that proliferated before the introduction of invasive mammals (Gibbs, 2010). It has also been hypothesised that New Zealand carabids are particularly longlived surviving for many seasons, however this has only been demonstrated for a few species whose overall lifespans are still unknown (Hutchison, 2007).

Carabids are often the subject of scientific studies in Europe and North America as they are often thought to be suitable indicator species for environmental monitoring due to their sensitivity to a range of environmental variables such as pollution, habitat modification and climate (Larochelle \& Larivière, 2013). The relative abundance and ease with which carabids 
can be collected through conventional collection methods such as pitfall trapping make them suitable species for monitoring. Although there is very little ecological information available for individual species in New Zealand the fact that many are large and conspicuous allows for relatively robust taxonomic identification of many of the larger species (Larochelle \& Larivière, 2001; Seldon \& Buckley, 2019).

\subsubsection{Scarabaeidae (dung beetles)}

Coleoptera within the Scarabaeidae family are characterised by their small, robust, rounded shape and the possession of clubbed antennae made up of three flattened plates which allow many of them to detect food resources. This family includes chafer beetles and dung beetles both of which are represented amongst New Zealand Scarabaeidae fauna (Watt, 1984). Dung beetles in other regions of the world are known for their habit of feeding on mammalian dung which they sometimes collect into balls which can be rolled away for later consumption. Partly due to the absence of indigenous land mammals, New Zealand has relatively few species of dung beetle with only 15 endemic species recorded (Stavert, Gaskett, et al., 2014). New Zealand's endemic dung beetles are also unusual owing to their small size (3-12mm) and the fact that they are flightless and nocturnal. One of the most common dung beetles in New Zealand is Saphobius edwardsii, which has been relatively common since the arrival of humans despite the disappearance of many major sources of dung such as seabirds and large indigenous herbivores such as the moa (Dinornithiformes) from native forests. S edwardsii has shown itself to be a generalist dung beetle and is attracted to a wide range of carrion and dung sources often with a preference for marine derived resources such as squid which can be used as a bait to allow for increased pitfall catch (Jones et al., 2012; Stavert, Drayton, et al., 2014; Stavert, Gaskett, et al., 2014; Vergara et al., 2020). It is not known to what extent introduced mammals effect indigenous Scarabaeidae but since scarabs are typically detritivores they may be sensitive to changes in the availability of carrion and dung, both of which are likely influenced by the effect of mammals on nutrient sources.

\subsubsection{Curculionidae (weevils)}

Curculionidae are a highly diverse family of herbivorous beetles commonly referred to as weevils. Relatively little is known about the basic ecology of most weevil taxa found in New Zealand apart from a handful of the larger more charismatic species such as members of the Anagotus genus and giraffe weevils (Lasiorhynchus barbicornis) (Miskelly et al., 2018; Painting \& Holwell, 2014). As with other indigenous taxa it is thought that New Zealand's 
indigenous Curculionidae are more likely to display traits such as increased size, flightlessness and a tendency to be nocturnal relative to Curculionidae from other regions historically subjected to mammalian predation. Research comparing the invertebrate diversity of fossil deposits in the North Island of New Zealand identified several large weevil taxa e.g. Anagotus, and Tymbopiptus valeas absent from present day beetle communities (Watts et al., 2019). Similar results were found in a study of fossil remains in the Canterbury region of in the South Island of New Zealand which identified the presence of several large ( $>5 \mathrm{~mm})$ weevil species across a much greater range than the present extent of these species (Kuschel \& Worthy, 1996). These species were Anagotus stephenensis (Ngaio weevil, 23-27mm), Anagotus rugosus (Coprosma weevil, 9-15mm), Hedramphus tuberculatus (Spaniard weevil, 9-17mm) and Ectopsis ferrugalis (Five finger weevil, 8-16mm). Both A. stephenensis and A. rugosus are confined to offshore islands free of introduced mammalian predators, A stephenensis are currently confined only to Stephen's Island in the Cook Strait whilst A. rugosus has a broad distribution from Three Kings Island to Fiordland. The historical distribution of the species across the mainland South Island of New Zealand and the fact that they are currently limited to offshore islands suggests the strong probability that these species have disappeared at least in part from most of their historical range due to the arrival of mammalian predators.

Weevils have been found to make up a large portion of mouse diets in some ecosystems such as Marion island (Parkes, 2019; Van Aarde et al., 2004). Hedgehogs are also known to consume weevils in moderate numbers with one study finding evidence of weevil consumption in roughly $30 \%$ of the stomachs of hedgehogs examined (Hendra, 1999). Other large weevil species thought to be impacted by mammalian predation include Anagotus fairburni (flax weevil, 20-24mm) and Hedramphus stilbocarpae (knobbled weevil, 16-22mm) for which only relict populations persist in areas with low mammal densities. Rats are thought to be a particularly significant cause of the declines of these species with the species seemingly able to persist in areas with mouse and stoat predation (Miskelly et al., 2018).

\subsubsection{Staphylinidae (rove beetles)}

Beetles in the Staphylinidae family, often referred to as rove beetles, can be carnivorous scavengers, predators and occasionally herbivorous. They feature shortened wing casings and a long slender body similar in overall appearance to an earwig. The Pselaphinae subfamily is often identified seperatley from Staphylinidae due to their highly distinctive morphology but are considered here part of Staphylinidae. Staphylinidae typically have a preference for damp 
sheltered habitats, but can be found in most terrestrial environements. Staphylinidae have often shown weak responses to changes in mammal predator abundance and are known to exhibit predator avoidance behaviours and chemical defence mechanisms which may make them less vulnerable (Gnanasunderam et al., 1981; Vergara, 2018; Watts et al., 2020). Very little is known about New Zealand Staphylindiae specifically, however as with other elements of New Zealand's invertebrae fauna it is a highly species rich with estimates of over 1000 species and display high levels of endemism (>90\%) (Klimaszewski et al., 1996).

\subsubsection{Elateridae (click beetles)}

Elateridae refers to a beetle family characterised by long cylindrical slightly flattened bodies, they are found in vegetation, in tree foliage, under tree bark and in leaf litter and are typically between 3-30mm. Commonly known as click beetles, they are so named for their habit of clicking to propel themselves out of the reach of predators or right themselves when they are on their back. Many members of the Elateridae are flighted, but many New Zealand species appear slow moving and flightless (Marris \& Johnson, 2010). New Zealand is thought to have in the region of 136 species of Elateridae in 26 genera although more likely remain undiscovered (Klimaszewski \& Watt, 1997). Elateridae larvae are sometimes referred to as wireworms and many species are considered environmental pests in New Zealand. Elateridae have been found in the diets of mammal species such as hedgehogs however information on their general ecology and response to introduced mammalian predators is lacking (Bremner et al., 1984; Jones et al., 2005).

\subsubsection{Tenebrionidae (darkling beetles)}

Tenbrionidae refers to a large diverse family represented by around 149 species in New Zealand. They are commonly known as darkling beetles and most typically feed on dead organic material although some native species feed on lichens. Typically, Tenebrionidae can be found in the soil, leaf litter and under dead logs (Watt, 1992). One feature of Tenebrionidae which may make them more sensitive to mammal predation is their generally large size and a tendency to be flightless. Many tenebrionids are known for the defensive secretions which they use to deter predators (Gnanasunderam et al., 1981). Tenebrionids have been found in the scats of several introduced mammal species and there are several relatively large species such as those in the genus Mimopeus which it has been hypothesized may be more vulnerable to mammal predation (Bowie, 2008; Campbell et al., 1984; Watts et al., 2014) 


\subsubsection{Lucanidae (stag beetles)}

Lucanidae refers to the stag beetles, a beetle family represented by 35 native and 4 exotic species in New Zealand. Stag beetles are known for the distinctly large mandibles found on the males of many species often thought to resemble antlers. New Zealand Lucanidae vary in size, but the largest species are no larger than $34 \mathrm{~mm}$ excluding mandibles. Males within the Geodorchus genus can reach $44 \mathrm{~mm}$ in length including the mandibles, demonstrating the level of sexual dimorphism present in some species. Some species are flighted whilst others are flightless but the generally large size of Lucanidae likely makes them vulnerable to mammalian predators, particularly those within Geodorchus (Bremner et al., 1984; Holloway, 2007).

\subsubsection{Other families}

There are over 82 beetle families in New Zealand more than 1092 genera and information relating to the ecology of most species and genera within them is lacking. The larger more conspicuous species in the families mentioned above tend to be the most well described and are thought to be among the most vulnerable to mammal predation although little information is available relating to smaller less conspicuous species in other beetle families (Leschen et al., 2003).

\subsection{Introduced mammal species}

\subsubsection{Rats}

Three rat species have been introduced to New Zealand following the arrival of humans around 900 years ago, these are Rattus exulans (kiore or pacific rat), Rattus novegicus (brown or Norway rat) and Rattus rattus (black or ship rat). The first of these three species to arrive was $R$. exulans which was brought with early Māori settlers arriving from Polynesia and have been estimated to have arrived in the $13^{\text {th }}$ century CE with $R$. novegicus and $R$. rattus arriving in the $18^{\text {th }}$ and $19^{\text {th }}$ century respectively (Russell et al., 2019). Most rats present in the New Zealand forests are thought to be ship rats which are assumed to be competitively dominant in forest environments, in part due to their superior climbing abilities (Efford et al., 2006; Foster et al., 2011). Rats are generalists, able to make use of a range of different resource types such as fruit, seeds and invertebrates and are found across a range of habitats achieving particularly high densities close to human settlements (Campbell et al., 1984; Miller \& Miller, 1995). The impact of rats on New Zealand vertebrates is well documented and they are typically considered one of the most significant threats to indigenous biodiversity in New Zealand (Russell et al., 2015). 


\subsubsection{Mice}

Mice (Mus musculus) are thought to have arrived in New Zealand in the late $18^{\text {th }}$ century with the arrival of European trading ships in at least two separate colonisation events, and are now found throughout New Zealand (King, 2016). Although not considered as great a threat to indigenous wildlife as other introduced mammals such as rats, stoats and possums, studies have shown them to have destructive impacts on indigenous bird and invertebrate communities (Broome et al., 2019; Miller \& Miller, 1995; Russell, 2012; Russell et al., 2020; Van Aarde et al., 2004; Watts et al., 2011; D. J. Wilson et al., 2018). This effect seems to be particularly acute in environments where they are the sole mammal predator where they can achieve much higher populations densities (D. J. Wilson et al., 2018). As with rats, mice are generalist species making use of fruit, seeds and invertebrates. Some evidence suggests that prey preference can shift from seeds to invertebrates depending on the season and the availability of resources (Miller \& Miller, 1995; Russell et al., 2020).

\subsubsection{Hedgehogs}

Hedgehogs are thought to be the one of the most significant introduced insectivores due to the prolific amount of invertebrates they are estimated to consume $\left(120 \mathrm{~g} \mathrm{animal}^{-1}\right.$ night $\left.^{-1}\right)$ and their relatively high population densities $\left(5.5\right.$ animals $\left.^{-1} \mathrm{ha}^{-1}\right)$ in native forests (Innes et al., 2010). Unlike other introduced mammals which show greater omnivory and rely more heavily on fruits and vegetation for food, hedgehogs primarily feed on invertebrates which can account for around half of the relative volume of hedgehog stomach contents (Nottingham et al., 2019). Unlike other introduced mammal species in New Zealand hedgehogs are also known to hibernate in most regions limiting their activities primarily to spring and summer (Brockie, 1958). Although more commonly encountered at lower elevations they are infrequently encountered above $1500 \mathrm{~m}$ (Foster et al., 2021). Hedgehogs are known to predate a range of threatened taxa including, indigenous ground nesting birds, lizards and invertebrates, and it is thought that they represent major threats in certain habitats (Jones \& Norbury, 2011; Jones et al., 2013).

\subsection{Beech masts and mammal population dynamics}

Mammal density, particularly of mice (Mus musculus), is known to fluctuate according to resource availability and predation pressure from other mammal species in native New Zealand forests (D. J. Wilson et al., 2018). A feature of many New Zealand plant communities is the 
occurrence of mast events at multiyear intervals leading to a dramatic increase in seed production and resource availability. This can cause periodic explosions in the populations of invasive mammals which negatively impact on the abundance of indigenous wildlife (Elliott $\&$ Kemp, 2016). This effect is thought to be particularly pronounced in relatively cold South Island beech (Nothofagus) forests where greater differences in resource availability between mast and non-mast years can increases the amplitude of mammal population fluctuations. These periodic population irruptions lead to an increase in the levels of predation experienced by indigenous fauna particularly once other mammal food sources have been exploited (O'Donnell \& Hoare, 2012).

Large native organisms such as birds are typically unable to respond as rapidly to these changes in resource availability often displaying more K-selected characteristics such as long lifespans, longer periods between breeding evens and reduced clutch size compared with introduced mammals which can produce large litters and exhibit short generation times (Starling-Windhof et al., 2011). How exposure to repeated mammal population irruptions affects native biodiversity relative to more stable mammal population abundances is not well understood. Linear models are often able to predict the response of taxa to increases in the abundance of their predator, but these can often be inadequate for describing the complex relationship between two species. For instance, Hemdeina thoracica (Auckland tree wêtā) are thought to be most heavily impacted when rat density is above three to four individuals per hectare, but can tolerate lower densities of rats (Norbury et al., 2015). The effect of beech masts on large species such as birds and reptiles is widely understood to be detrimental due to the increase in mammal populations, but how this impacts on invertebrate communities is not well known. Increased beech seeding increases resource availability for invertebrates which can lead to increases in invertebrate populations as has been documented for lepidopteran larvae and spiders, but may be detrimental if mammal populations increase also (Alley et al., 2001).

The issue of predicting populations of invasive mammals in New Zealand is complicated further by the interactions between different mammal species (Tompkins et al., 2013). Eleven insectivorous mammals have become naturalised in New Zealand representing a range of trophic guilds these include three species of rats (kiore Rattus exulans; Norway rat Rattus norvegicus; and ship rat Rattus rattus ), house mice (Mus musculus), hedgehogs (Erinaceus europaeus), three species of mustelids (stoat Mustela erminea; ferrets Mustela furo; and weasel Mustela nivalis), feral cats (Felis catus), brush tailed possums (Trichosurus vulpeca) and feral pigs (Sus scrofa) (Table 1.1) (McGuinness, 2007). 
Interactions between these species, in particular between rats, mice and mustelids, mean that large fluctuations in the abundance of one mammal species can directly impact on the abundance of another leading to indirect cascading effects on other species (Tompkins \& Veltman, 2006). For instance, populations of mice in New Zealand are thought to be heavily regulated by populations of other mammals such as rats and mustelids which compete with and predate upon them (D. J. Wilson et al., 2018). This has been a problem when trying to implement mammal control in predator free sanctuaries and islands where the removal of rats and mustelids leads to a corresponding increase in mouse abundance which are typically much harder to eradicate and fence out (Angel et al., 2009).

Studies on the impact of mice on invertebrate communities suggest that mice have a particularly strong impact on wêtā as well as less significant impacts on some beetle taxa (Watts et al., 2020). Mice consume large quantities of invertebrates $2 \mathrm{~g} \mathrm{animal}^{-1}$ night $^{-1}$ (Innes et al., 2010) but are normally limited to densities of $<6$ mice $^{-1} a^{-1}$ when other invasive mammals are present. Mice have been recorded reaching densities as high as 46 mice ha $^{-1}$ at Maungautatari following the eradication of other mammals and can reach densities as high as 50 mice ha $^{-1}$ following beech masting events (D. Wilson et al., 2018).

Amongst indigenous bird species periodic predator control through the aerial application of toxic baits at multi-year intervals can be sufficient to allow bird populations to persist by allowing sufficient respite for birds to successfully reproduce (Byrom et al., 2016; Fea et al., 2021; Ruscoe et al., 2013). This method of repeated predator control on a three to six to year cycle may be sufficient for the conservation of indigenous birds but, the impacts of this approach on invertebrates is not obvious. The speed with which invertebrate populations respond to changes in mammal predation pressure is similarly not well established (Watts et al., 2020; Watts et al., 2014). Invertebrates are typically much more impacted by factors such as temperature and resource availability which can make it difficult to attribute changes in in invertebrate abundance to changes in mammal predation (Cardoso \& Leather, 2019; Dornelas \& Daskalova, 2020; Saunders et al., 2020; Vergara, 2018). Some have suggested that the relatively long lifespans and generation times of New Zealand invertebrates may lead to a comparatively slow recovery of invertebrate fauna following a decline in mammal population density and that it may take a long period of time for responses to become apparent (Cartellieri \& Lövei, 2003; Leschen et al., 2012; Rickard, 1996; Watts et al., 2014). Invertebrates typically produce larger numbers of offspring than vertebrate predators which would indicate a greater capacity to respond to reductions in mammal predator abundance. This may have allowed many 
invertebrate taxa to persist in New Zealand despite centuries of mammal predation and make invertebrates in general more resilient to top down predator effects, whilst larger, slower reproducing species perished (Ruscoe et al., 2013).

Table 1.1 Introduced mammalian insect predators in New Zealand estimated establishment dates, mean body mass and feeding guild (King \& Forsyth, 2021)

\begin{tabular}{|c|c|c|c|}
\hline & $\begin{array}{ll}\text { Date } & \text { of } \\
\text { establishment } & \end{array}$ & $\begin{array}{l}\text { Mean adult Body mass } \\
\text { (g) }\end{array}$ & Feeding guild \\
\hline Kiore (Rattus exulans) & 1250-1300 CE & $60-80$ up to 180 & Omnivore \\
\hline $\begin{array}{l}\text { Norway rat (Rattus } \\
\text { norvegicus) }\end{array}$ & 1770-1830’s & $200-300$ up to 450 & Omnivore \\
\hline Ship rat (Rattus rattus) & 1830-1860’s & $120-160$ up to 225 & Omnivore \\
\hline Mice (Mus musculus) & 1788-1830’s & $15-20$ up to 30 & Omnivore \\
\hline $\begin{array}{l}\text { Hedgehogs (Erenacius } \\
\text { europeus) }\end{array}$ & 1870’s & $300-1300$ & $\begin{array}{l}\text { Omnivore (Primarily } \\
\text { invertebrates) }\end{array}$ \\
\hline $\begin{array}{l}\text { Possum (Trichosurus } \\
\text { vulpecula) }\end{array}$ & 1858 & $1400-6400$ & $\begin{array}{l}\text { Omnivore (Primarily } \\
\text { vegetation) }\end{array}$ \\
\hline $\begin{array}{l}\text { Weasel } \\
\text { nivalis) }\end{array}$ & 1880’s & $\begin{array}{l}126 \text { (male) } \\
57 \text { (female) }\end{array}$ & Carnivore \\
\hline $\begin{array}{l}\text { Stoat } \quad \text { (Mustela } \\
\text { erminea) }\end{array}$ & 1880’s & $\begin{array}{l}324 \text { (male) } \\
207 \text { (female }\end{array}$ & Carnivore \\
\hline $\begin{array}{l}\text { Ferret (Mustela } \\
\text { putorius furo) }\end{array}$ & 1880’s & $\begin{array}{l}1200 \text { (male) } \\
600 \text { (male) }\end{array}$ & Carnivore \\
\hline Cat (Felis catus) & 1769-1830’s & $\begin{array}{l}1080-7000 \text { (male) } \\
1150-4600 \text { (female) }\end{array}$ & Carnivore \\
\hline Feral pigs (Sus scrofa) & 1769-1790’s & $\begin{array}{l}\text { 45-205kg (boars) } \\
32-114 \mathrm{~kg} \text { (sows) }\end{array}$ & Omnivore \\
\hline
\end{tabular}

\subsection{Predator control}

Invasive mammals are recognised as a serious environmental problem in New Zealand and one of the most significant threats to indigenous diversity (Dilks et al., 2020; Lester et al., 2014; Russell et al., 2015). This is encapsulated in the government's plan to eradicate all invasive predators from New Zealand by 2050 (Russell et al., 2015). The control of invasive mammalian 
predators in New Zealand is conducted by a range of organisations for both economic and conservation purposes (Innes et al., 2019). One of the most significant economic impacts of invasive mammals is the spread of tuberculosis by possums to herds of dairy cattle from nearby bush remnants (Ramsey \& Efford, 2010).

A range of different means of predator control are used in New Zealand for different applications and on different environmental scales (Elliott \& Kemp, 2016; Pech \& Maitland, 2016; Warburton \& Livingstone, 2015). These measures can include ground-based predator control using mechanical baited traps or poison bait stations placed at regular intervals throughout an area and are checked regularly. Ground based predator control is typically the most common method for most small and medium scale predator control operations and urban or semi-rural areas where there is ample accessibility to trap locations (Chand \& Cridge, 2020; Glen et al., 2019). In more remote inaccessible terrain, it is more common to use aerial application of mammal toxins to achieve reductions in mammal populations (Dilks et al., 2020; Eason, 2002).

\subsubsection{0 predator control}

1080 is the commercial name for sodium fluroacetate, a toxin used to control populations of introduced mammal species such as rats, possums and mustelids in New Zealand (Dilks et al., 2020). 1080 is a naturally occurring compound found in low concentrations in several indigenous plant species, but is produced synthetically for use in controlling invasive predators. 1080 is preferred in many applications in New Zealand for its effectiveness in controlling many introduced species of mammals simultaneously and because it can be applied aerially over large areas without leaving significant residue in waterways or the environment (Eason, 2002; Murphy et al., 1999). When applied aerially 1080 is typically used at multiyear intervals to achieve a knock down of invasive predators to provide enough respite for native organisms susceptible to mammal predation to recover. 1080 is preferred because it simultaneously controls rats and possums through direct consumption of poison pellets and targets mustelids through secondary poisoning which occurs when scavenging the carcases of mammals which have consumed the bait directly. This method is thought to be sufficient to allow for the for the maintenance and recovery of some native bird species but whether this is sufficient to provide benefits to other less well-known taxa and invertebrates is less well known (Dilks et al., 2020; Elliott \& Kemp, 2016). 


\subsubsection{Indirect effects of mammals on invertebrates}

Prior to the arrival of humans and the introduction of invasive mammals, birds would have dominated the early ecosystems of New Zealand and nutritional subsidies would have been significantly different to how they are in the present day (Gibbs, 2010; Hawke et al., 1998). The dung and carrion provided by bird species would likely have been significant food sources for invertebrates and changes in the availability of these resources has likely had an impact on invertebrate communities (Jones et al., 2012; Stavert, Gaskett, et al., 2014; Wardle et al., 2001). In island ecosystems where mammals have been removed increases in the abundances of certain invertebrate taxa have often been documented. This is often attributed to the return of seabirds and other native organisms which can increase soil fertility and nutrient availability leading to strong responses in invertebrate communities (Fukami et al., 2006).

In addition to the smaller predatory mammals such as rats, mice and hedgehogs, large herbivorous organisms such as deer, goats and feral pigs are often present in many native forests. These large herbivores modify indigenous vegetation thorough the effect of browsing and alter nutrient subsidies and soil communities (Wardle et al., 2001). It is not clear whether indigenous invertebrates, that would typically have fed on dung and carrion from birds in pre human times, are able to utilise these mammalian derived inputs, although it appears that the native dung beetle Saphobius edwardsii shows a more generalist response to dung from a range of sources (Jones et al., 2012; Stavert, Drayton, et al., 2014; Stavert, Gaskett, et al., 2014). The impact of changes in nutrient subsidies due to introduced mammals is likely to be most strongly felt by detritivores such as scarabs. Studies have shown that the use of marine derived carrion in the form of squid baiting of pitfall traps is a reliable way of increasing the catch rates of certain classes of invertebrates particularly for detritivores and carrion feeding species (Seldon \& Beggs, 2010). Squid baiting in pitfall traps in the Aorangi and Remutaka ranges has resulted in increasing the catch of several invertebrate taxa including ground wētā (Hemiandrus spp), cave wētā (Fam: Rhaphidophoridae), carabids, Staphylinidae and Scarabaeidae (Vergara et al., 2020).

\subsection{Project aims \& thesis structure}

This thesis aims to understand which invertebrate taxa within the orders Coleoptera and Orthoptera show the strongest responses to changes in introduced mammalian insectivores in mainland New Zealand forests. It also evaluates evidence for the hypothesis that increased 
invertebrate size increases vulnerability to mammal predation. Wammal tracking rates were compared with invertebrate size and abundance metrics in mainland forests to test for correlations. Whilst I was the primary researcher on this project and was responsible for the writing, analysis, and invertebrate identifications, most of the fieldwork which enabled this research was undertaken by previous students, researchers and research assistants dating back to 2012. Further details on the invertebrate sorting are found in the methods.

This thesis consists of four chapters. Chapter One is an introductory and methods chapter relating to the collection of invertebrates, sorting and model construction. Chapter One also includes a summary of invertebrate collections across the study sites. This is followed by two results chapters focussing on the responses of Coleoptera (Chapter Two) and wêtā (Chapter Three). The final chapter consists of a general discussion of the research implications and areas for future research.

\subsection{Methods}

\subsubsection{Study Location}

Invertebrate samples for this study were collected from the Remutaka ( $\mathrm{n}=2$ sites) and Aorangi ( $\mathrm{n}=5$ sites) ranges in the Wairarapa region of the lower north island of New Zealand. Seven sites, shown in Figure 1.1, across the two forest parks were regularly used for sampling. Both areas are mountainous and protected forests that undergo regular pest control in the form of 1080 drops to reduce populations of invasive mammalian predators. The Aorangi sites received aerial 1080 application twice during the study period, in August 2014 and June 2017, the Remutaka sites received 1080 only in September 2018.

The Remutaka Forest includes the Orongorongo Valley and Warongomai sites. The ecology of the Orongorongo Valley has received attention in the past with studies examining the invertebrate fauna as well as hedgehog and feral cat abundance (Alley et al., 2001; Efford et al., 2006; Fitzgerald et al., 2004; Moeed \& Meads, 1983, 1985, 1987). Annual rainfall collected by NIWA from the Orongorongo Valley for the period 2012-2019 ranged from 1121 to 1878 $\mathrm{mm}$ and mean minimum temperature each year ranged from 7.9 to $9.1^{\circ} \mathrm{C}$ (Hartley \& Fea, 2020). The Remutaka study sites consist of a mix of podocarp-hardwood and beech forest. The Aorangi forest park consists of five regularly sampled sites distributed across the park. These sites go through several forest habitats ranging from gorse (Ulex europeus) and kānuka (Kunzea ericodes) scrub to podocarp-hardwood and beech forest. Significant seed producing tree 
species recorded at the study sites include kamahi (Weinmannia racemosa), kānuka, hinau (Elaeocarpus dentatus), rimu (Dacrydium cupressinum) and three species of beech (red beech Fuscospora solandri; silver beech Lophozonia menziesii; and black beech Fuscospora solandri). Beech mast years occurred across both forests in 2014 and 2019 with excess beech seedfall mostly occurring in the summer and autumn (February-June). Elevation at each of the sample sites was between $150-800 \mathrm{~m}$ above sea level.

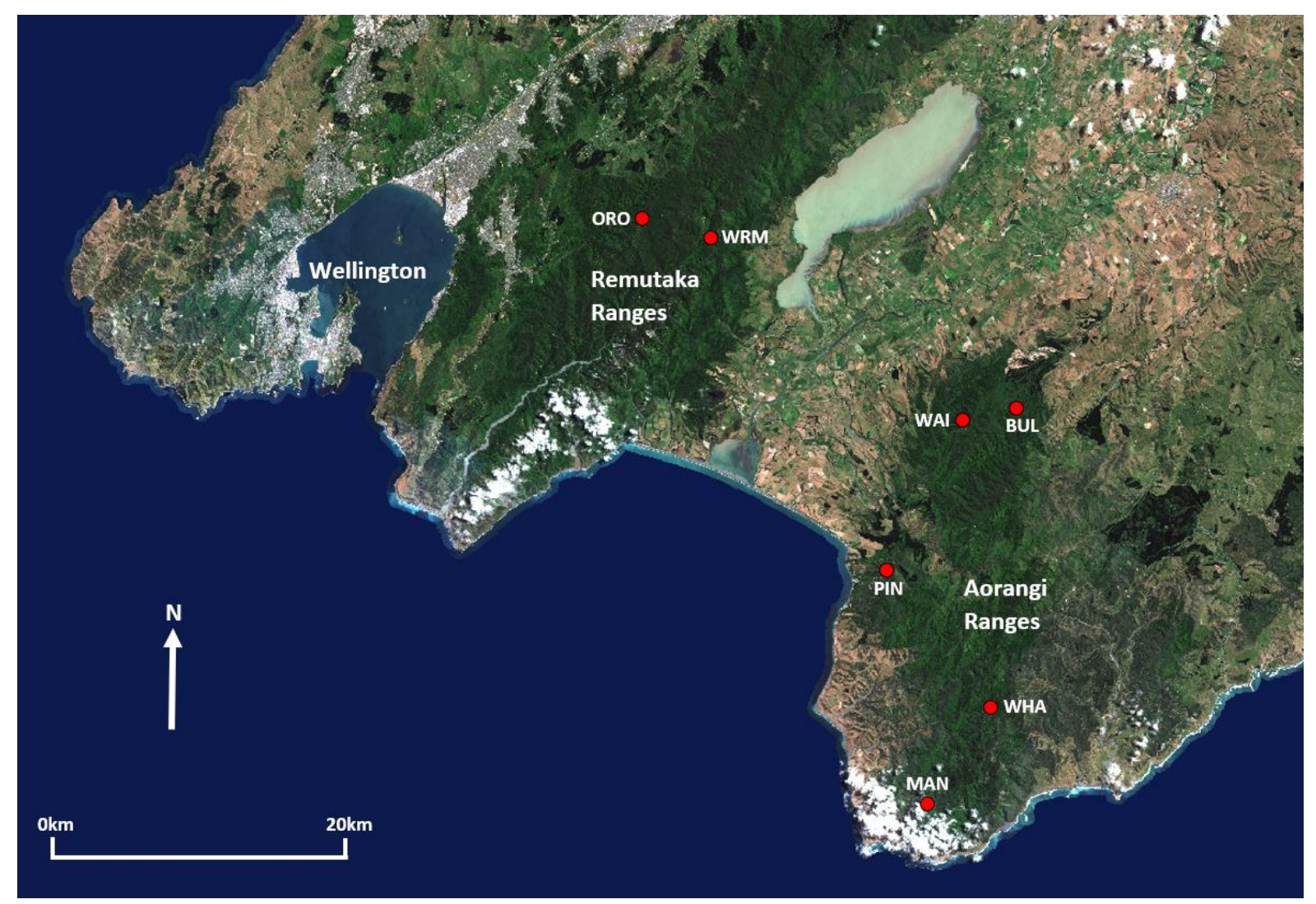

Figure 1.1 Study locations, background map from Greater Wellington Regional Council

\subsubsection{Mammal tracking}

Mammal tracking data comes from a database maintained as part of Stephen Hartley's "Biodiversity responses to possum control in the Aorangi and Haurangi Forests" project (2020) established in November 2012. At each of the seven regularly monitored sites three monitoring lines have been established for a total of 21 monitoring lines. Sampling takes place at each site three times each year, in November/December (spring), February (summer) or June/July (winter).

Each line is $450 \mathrm{~m}$ in length with a range of biodiversity and environmental variables monitored along its length. Lines were separated by a minimum of $500 \mathrm{~m}$ and were placed at least $300 \mathrm{~m}$ from the forest edge. Mammal monitoring is in the form of 10 tracking $(\mathrm{LxWxH}=50 \times 10 \times 10$ 
$\mathrm{cm})$ tunnels placed at $50 \mathrm{~m}$ intervals along the length of the monitoring line. These tracking tunnels utilise an ink pad to record the footprints of mammals that enter the tracking tunnel and are baited either with peanut butter or dried rabbit meat (Erayze block) placed in the middle of the tracking tunnel. Peanut butter is typically used to attract rats and mice whilst meat is used to attract carnivorous mammals such as hedgehogs and mustelids. In the summer season (February) bait alternates between peanut butter and meat for each tracking tunnel whilst in the spring and winter only peanut butter is used. Tracking tunnels were left either overnight (June and November) or for a total of three nights (February) before collection.

Mammal tracking indices averaged by site and season which were then assigned to each of the pitfalls across the site for each of the mammal species (rat, mouse or hedgehog). This is calculated as (Number of tunnels with footprints/Number of tunnels collected in total) for each mammal species. The tracking tunnels index from the three-night monitor is then adjusted to a one-night equivalent using the formula:

$$
1-(1-\text { mean tracking rate })^{0.667}
$$

\subsubsection{Pitfall trapping}

Invertebrate samples were collected utilising pitfall traps placed in the centre of the monitoring lines between $200 \mathrm{~m}$ and $250 \mathrm{~m}$ for a total of seven pitfalls per monitoring line, pitfalls were alternately baited with squid bait nailed to the underside of the pitfall lid or were left unbaited, see configuration in Figure 1.2. Pitfall traps consisted of cylindrical plastic containers (diameter $110 \mathrm{~m})$ dug into the ground and filled up to quarter with $35 \%$ sodium chloride $(\mathrm{NaCl})$ solution and a few drops of detergent (Vergara et al., 2020), this was both to kill invertebrate specimens and ensure they remained well preserved. The lip of the container was flush with the ground and a plastic lid was raised $20-25 \mathrm{~mm}$ above the lip of the container to prevent plant debris and large organisms from accessing the pitfalls, see Figure 1.3. 


\section{Line 1}

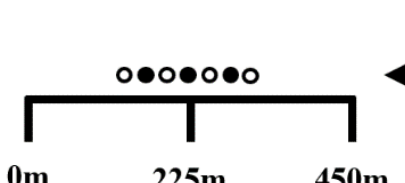

$\mathbf{0 m}$ $225 \mathrm{~m}$ 450m
Line 2

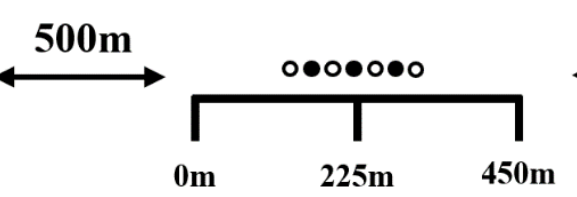

Line 3

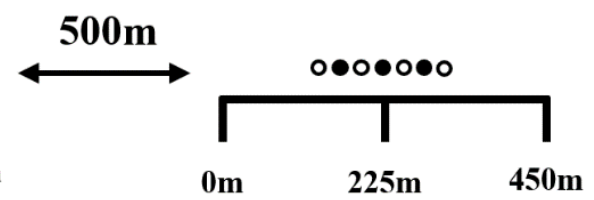

• = Baited pitfall trap

$0=$ Unbaited pitfall trap

Figure 1.2 Layout of monitoring devices at one site: Positioning of 21 pitfall traps (not to scale) centred along monitoring lines.

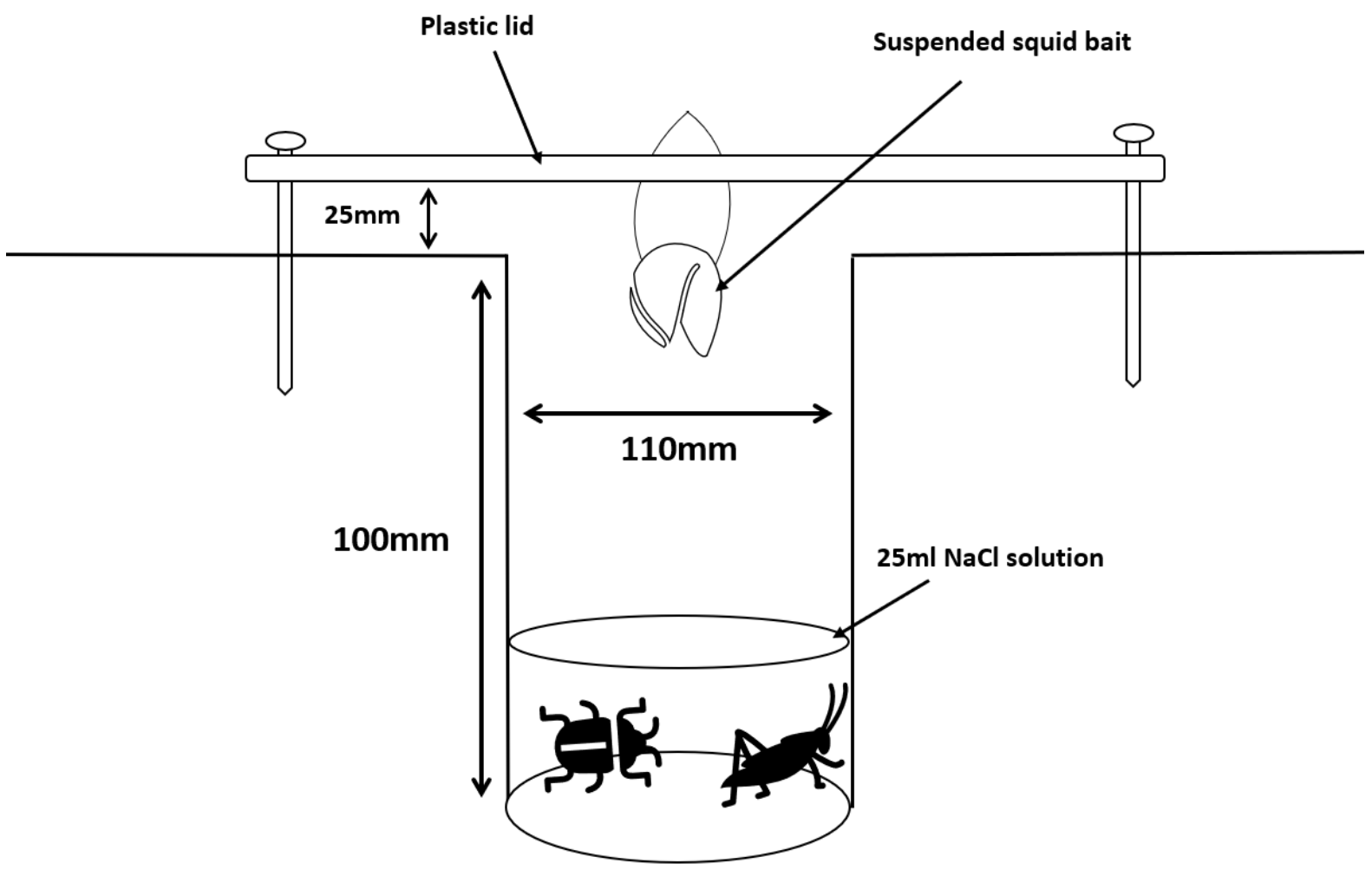

Figure 1.3 Squid baited pitfall trap

As with the tracking tunnels, pitfall traps were left in the field for three nights ( 72 hours) in the summer and one night ( 24 hours) in the spring. Pitfall trapping did not take place during the winter season (June/July). At the end of the sample period the contents of each pitfall were transferred into a separate plastic pottle filled with water and transported to the lab where water was replaced with $70 \%$ ethanol solution prior to sorting. 


\subsubsection{Invertebrate sorting}

Invertebrates were removed from their transport containers cleaned, sorted into four groups, and placed into smaller sealed plastic containers with fresh $70 \%$ ethanol solution along with other individuals from the same group. The initial sorting placed the invertebrates in one of Coleoptera (beetles), Arachnida (predominantly Spiders and harvestmen), Orthoptera (Anostostomatidae \& Rhaphorophoridae) and "other". Invertebrate collections from the study period Nov-2012 to Nov-2019 were sorted to order level by prior students and field assistants. The author was then responsible sorting for counting, measuring, sexing, and identifying all pitfall trapped Coleoptera and Orthoptera to species or morphospecies level.

For the purposes of analysis specimens were also assigned to one of 10 beetle families these included Carabidae (ground beetles), Chrysomelidae (leaf beetles), Curculionidae (weevils), Elateridae (click beetles), Lucanidae (stag beetles), sub-family Pselaphinae (ant like litter beetles), Scarabaeidae (scarab beetles), Staphylinidae (rove beetles), Tenebrionidae (darkling beetles) and "other beetles". Note Pselaphinae is technically within the family Staphylinidae but was treated as a separate family for the purposes of analysis. Beetle larvae were not included in this analysis due to the difficulty in monitoring them using traditional pitfall trapping methods and the lack of significant knowledge around larval ecology and identification (Lovei \& Sunderland, 1996). Beetles were measured to the nearest millimetre using callipers from the anterior point of the head to the posterior portion of the elytra excluding all external appendages jaws, antenna etc. Note that in all subsequent size plots invertebrate size has been randomly jittered to allow for easier data visualisation.

Orthoptera were additionally classified as male, female or immature. Wētā body size was measured from the anterior of the head to the posterior of the abdomen excluding ovipositors, legs and other appendages. In contrast with many other Orthoptera the ovipositor of many Hemiandrus (ground wētā) is short and inconspicuous making it a less reliable method of determining sex. Ground wētā were therefore sexed according the presence of the secondary copulatory organ located on the sixth sternite of female (Gwynne, 2002, 2005). Ground wētā $<18 \mathrm{~mm}$ were classified as juveniles due to the difficulty in distinguishing the difference in sex between individuals of this size. Cave wētā, which includes a range of species, were sexed according to the presence or absence of the large ovipositor which indicates the specimen is female and the absence of which indicates a male. Images of female ground and cave wētā are shown in Figure 1.7. 


\subsubsection{Motels}

Cavity dwelling tree wētā (Hemideina crassidens) were monitored using artificial tree cavities referred to as wētā motels. These observations were made in situ by previous students and research assistants. Wētā motels are hollow wooden boxes that can be nailed to trees and provide roost sites to cavity dwelling tree wêtā. The hollow interior "galleries" can be viewed through a wooden plate which swivels round to reveal the interior of the wētā galleries through a clear piece of plastic a diagram is shown in Figure 1.4. Around three to four wêtā motels were placed along each of the monitoring lines, approximately $1.5 \mathrm{~m}$ off the ground. As tree wêtā are nocturnal they can typically be found roosting in these cavities during the day making them easy to observe and record. Typically, a single gallery will consist of a single male who maintains a harem of several females, but occasionally multiple males will share a gallery. Wētā were counted, measured, and sexed in the field. Measurements were taken from the anterior portion of the head to the posterior portion of the abdomen to the nearest millimetre, excluding all external appendages using rulers. Males and females were sexed according to the presence or absence of an external ovipositor on the posterior portion of the abdomen individuals which could not be sexed were recorded as N/A. Although some individuals were recorded as juveniles there was no consistent criterion used to assess the age of tree wētā, therefore they were not analysed separately. Sample sizes reported in Table 1.4 reflect observations rather than individual wētā. 


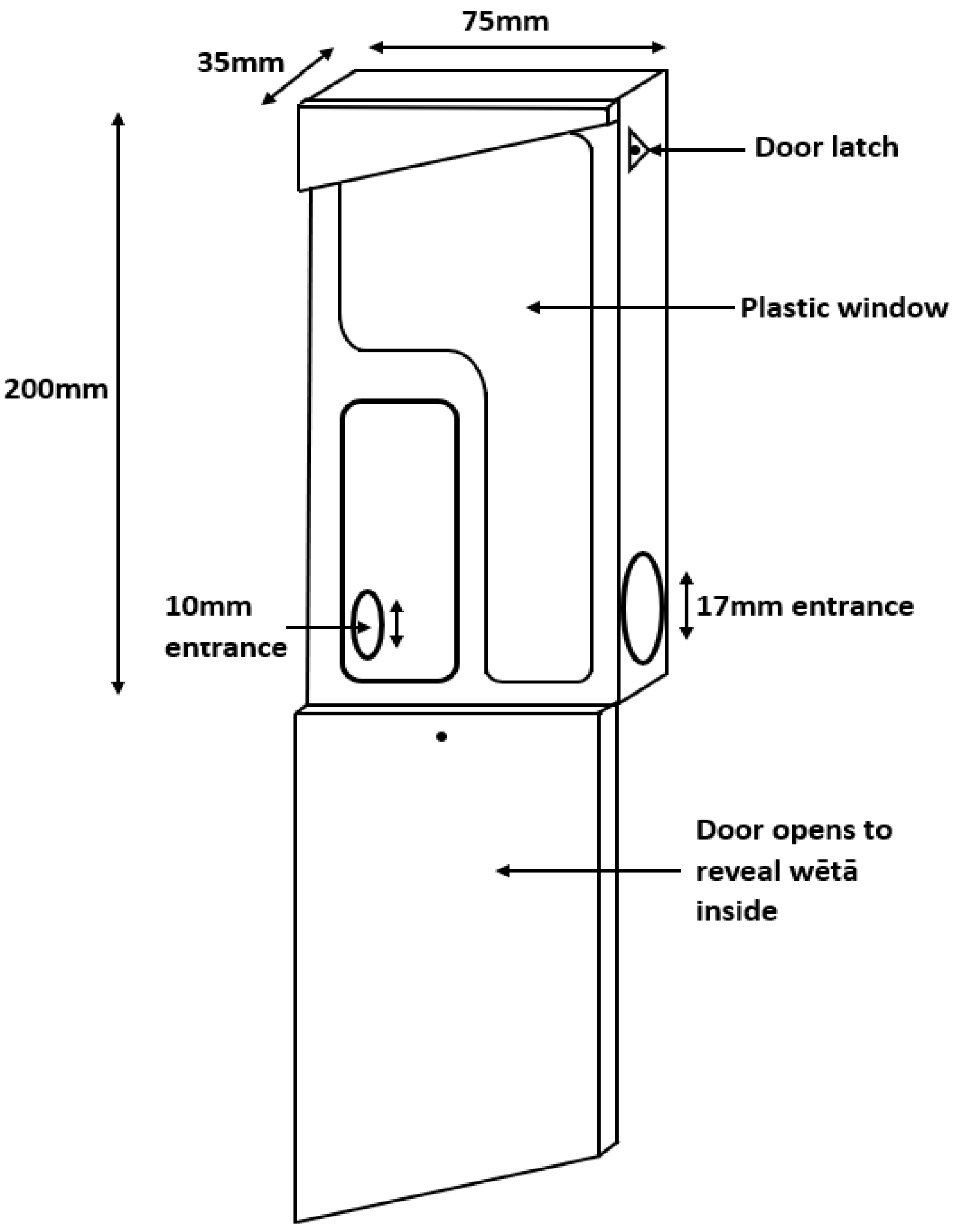

Figure 1.4 Wētā motel design 


\subsubsection{Analysis I - Model construction}

Linear mixed effects models were fitted using lme4 package in $\mathrm{R}$ to estimate the effect of increased mammal index on the size of invertebrates. Rat, mouse, and hedgehog tracking were included in the model as fixed effects (Box 1.1). Additional fixed effects included month (Feb or Nov) and whether the pitfall was baited with squid or not. Random effects in these models included the effects of site nested within forest. Type 3 analysis of variance models (ANOVAS) were used to test for significance using the "Anova" function. Mean tracking indices for each mammal species were calculated by site and year, not calculated per line, leading to an average score.

Generalised linear mixed models were used for the abundance scores to predict the impact of different mammal taxa on invertebrate catch (Box 1.2). Marginal and conditional $\mathrm{R}^{2}$ values have been calculated using the r.squaredGLMM function from the $\mathrm{R}$ package MuMin, according to the methods outlined in Nakagawa, Johnson, \& Schielzeth (Nakagawa et al., 2017). The $\mathrm{R}^{2}$ values reported for GLMMs in chapters two and three are trigamma estimates recommended for use where available. Estimates for LMER models are delta estimates. The threshold for significance for both the size and the abundance model was reduced to $\mathrm{P}<0.01$ to reduce the likelihood of familywise errors resulting from multiple similar comparisons.

Prior mammal abundance was also analysed using the mammal abundance from the previous seasons monitoring to account for the delayed effect of predator prey cycles and the effect on the size structure of invertebrate populations. This time delay is between three to four months i.e. comparing rat abundance from June to invertebrate size in November, this is represented in the result as T-1. The sample size for the T-1 model is smaller as calculating a historical index is not possible until at least one season of previous data has been collected.

\subsubsection{Analysis II - Coleoptera}

To reduce the occurrence of family wise errors associated with running multiple similar ANOVAS on different categories of beetles, only beetle families with a sample size $>100$ individuals over the period of interest are reported in this chapter and a conservative threshold of $\mathrm{p}<0.01$ is was to define significance. This includes three beetle families Carabidae, Scarabaeidae, Staphylinidae and “other beetles". Results for the remaining six beetle categories are included in the appendix but due to the low sample sizes these tests lack power and it is difficult to attach great significance to these results. The "other beetles" group refers to beetles 
not included in Carabidae, Scarbaeidae, Staphylinidae, Curculionidae, Elateridae, Lucanidae, Tenebrionidae or the subfamily (Pselaphinae) outlined in Chapter One.

\subsubsection{Analysis III - Ground dwelling wètā}

Pitfall trapped wētā were sorted into either cave (Rhaphidophoridae) or ground wētā (Hemiandrus) with adult ground wētā being further sexed according to the presence or absence of the secondary copulatory organ on the underside of the abdomen (Gwynne, 2002, 2005). Ground wētā were classed as adults if they were $>18 \mathrm{~mm}$ in size excluding all external appendages. All, apart from two specimens, belonged to Hemiandrus pallitarsis. Cave wētā were sexed according to the presence or absence of an ovipositor on the abdomen however, as cave wêtā is a large speciose group in the family Rhaphidophoridae this was not used for analyses. Details of the models used in this chapter can be found in Box1.1 and 1.2. A full species list can be found in the appendix Table 6.1.

\subsubsection{Analysis IV - Cavity dwelling wētā}

As motel data was collected by a many different observers over an extended period, different protocols for classifying juvenile tree wētā were used. Therefore, ANOVAS and statistical tests were not run on the juveniles. Individuals recorded as juveniles by observers are included in the tree wētā category along with male and female tree wētā. Individuals that could not be sexed were recorded as N/A for sex but still used in the tree wêtā grouping and used for model construction. Unlike pitfall sampling which only takes place twice a year (February and November), wētā motel monitoring takes place three times a year in February, June and November. Models were as for the pitfall trapped invertebrates but with no term for squid bait which is not used for wētā motels. Model construction for the size and abundance models are shown in Box 1.3 \& 1.4, the fixed effect Season referrers to the time of year (February, June or November) that measurements were made. 
Box 1.1 R code for pitfall size model, significance testing and $\mathrm{R}^{2}$ calculations

Size.model = lmer (Size.mm mean.Rat.Tmt.adj + mean.Mouse.Tmt.adj + mean.Hhog.Tmt.adj + Squid + Season + (1/Site/Line), data= coleoptera.df) summary (size.model)

Anova (Size.model, type $=3$ )

r.squaredGLMM (Size.model)

Box 1.2 $R$ code for pitfall abundance models, significance testing and $\mathrm{R}^{2}$ calculations

Abundance.model $=$ glmer $($ Family mean.Rat.Tmt.adj + mean.Mouse.Tmt.adj + mean.Hhog.Tmt.adj + Squid + Month +(1/Site/Line), family = poisson, data $=$ coleoptera.df

summary (Abundance.model)

r.squaredGLMM (Abundance.model)

Box 1.3 $\mathrm{R}$ code for tree wētā size model, significance testing and $\mathrm{R}^{2}$ calculations

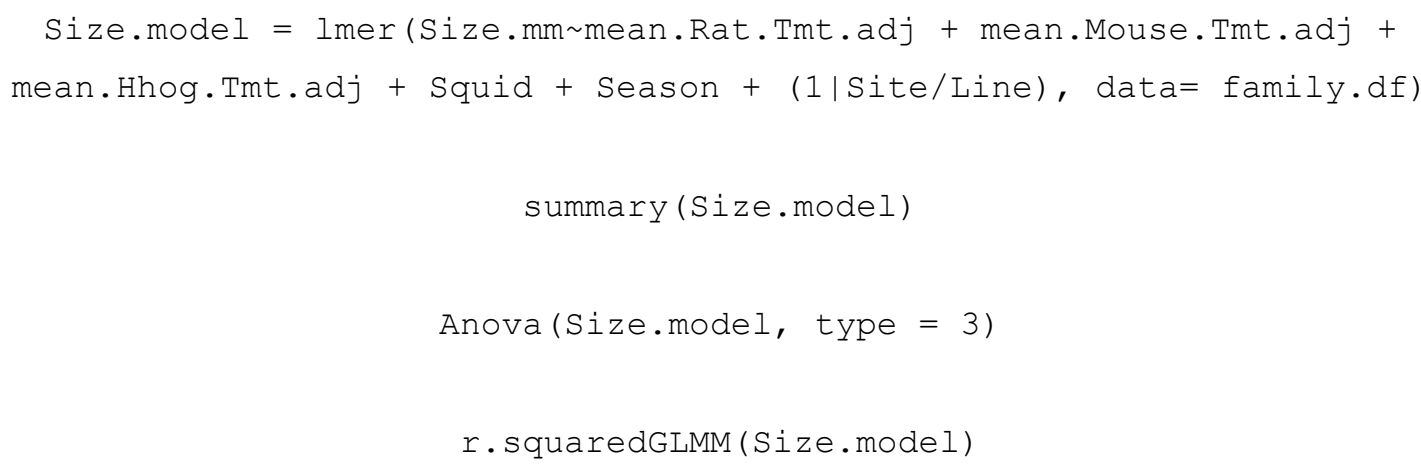


Box 1.4 $\mathrm{R}$ code for tree wētā occupancy model, significance testing and $\mathrm{R}^{2}$ calculations

Abundance.model $=$ glmer $($ Wētā.group mean.Rat.Tmt.adj + mean.Mouse.Tmt.adj

+ mean.Hhog.Tmt.adj + Season +(1/Site/Line), family = poisson,

data $=$ coleoptera. $d f$

summary (Abundance.model)

r.squaredGLMM (Abundance.model)

\subsection{Results I - Summary of samples collected}

\subsubsection{Beetles}

All beetles were assigned tag names resulting in 134 distinct taxa, 30 of these have been identified to species. Mean body length, number of recognized morphospecies and sample size are reported in Table 1.2 (note sample size refers only to those specimens for which a corresponding mammal index could be calculated). Some labels were illegible (predominantly from the 2016 collections) and could not therefore be assigned to specific pitfalls/sites. Lucanidae was the most well described family with both morphospecies identified to species level. Carabidae were the next best described group with 10 of the 15 morphospecies identified to species level, two of the four Tenebrionidae were identified to species level, two of the 15 Curculionidae, the five Scarbaeidae morphospecies were identified to genus level and 12 of the 73 other beetles were identified to species level. None of the Chrysomelidae, Elateridae or Staphylindiae could be identified to species level although one Staphylinidae morphospecies was identified to genus. A full description of the recorded taxa and tag names is shown in the appendix Table 6.2. 
Table 1.2 Beetle families mean size and sample size

\begin{tabular}{|c|c|c|c|c|c|}
\hline Beetle taxa & $\begin{array}{l}\text { Mean } \\
(\mathrm{mm})\end{array}$ & body length & $\begin{array}{l}\text { Interquartile } \\
\text { body size }\left(25^{\text {th }} \text { to }\right. \\
\left.75^{\text {th }} \text { percentile }\right)\end{array}$ & $\begin{array}{l}\text { Number of } \\
\text { morphospecies } \\
\text { recognised }\end{array}$ & Sample size \\
\hline Coleoptera (All families) & & 8.3 & $4-13$ & 134 & 3887 \\
\hline Carabidae (ground beetles) & & 15.9 & $12-18$ & 15 & 1310 \\
\hline Chrysomelidae (leaf beetles) & & 4.5 & $3.75-5.25$ & 1 & 2 \\
\hline Curculionidae (weevils) & & 4.8 & $3-5$ & 15 & 50 \\
\hline Elateridae (click beetles) & & 5.2 & $4-5$ & 5 & 66 \\
\hline Lucanidae (stag beetles) & & 14.8 & $14-14.5$ & 2 & 3 \\
\hline $\begin{array}{l}\text { Pselaphinae (Staphylinidae subfamily } \\
\text { ant like litter beetles) }\end{array}$ & & 2.6 & $2-3$ & 4 & 23 \\
\hline Scarabaeidae (dung beetles) & & 4.5 & $4-5$ & 5 & 1811 \\
\hline Staphylinidae (rove beetles) & & 8.0 & $3-12$ & 10 & 271 \\
\hline Tenebrionidae (darkling beetles) & & 12.9 & $7-20$ & 4 & 13 \\
\hline Other beetles & & 3.8 & $2-4$ & 73 & 416 \\
\hline
\end{tabular}



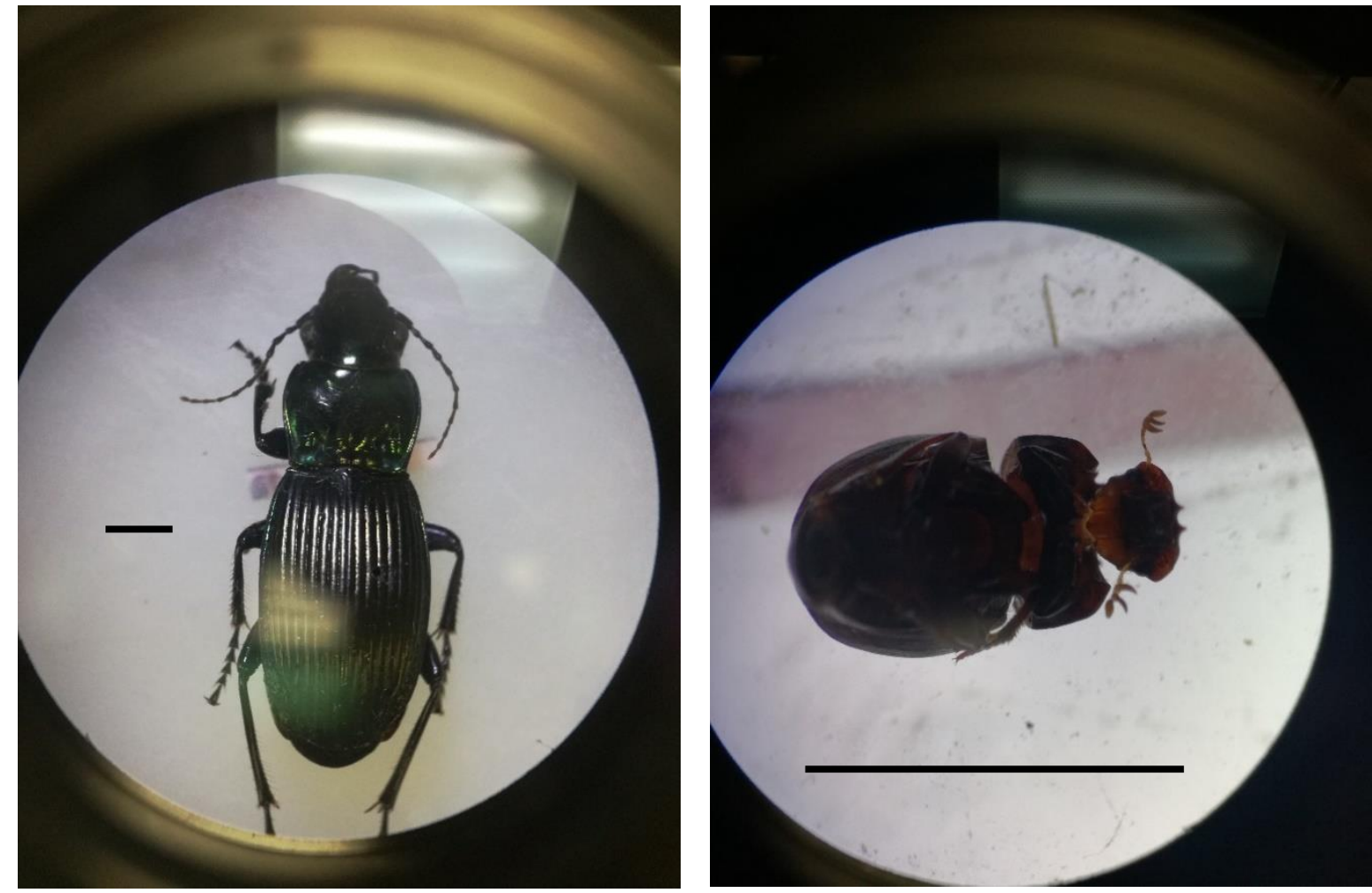

Figure 1.5 Beetles caught in pitfall traps Carabidae ground beetle Megadromus capito (left) and Scarabaeidae (Saphobius spp) (right). Scale bar $=5 \mathrm{~mm}$.
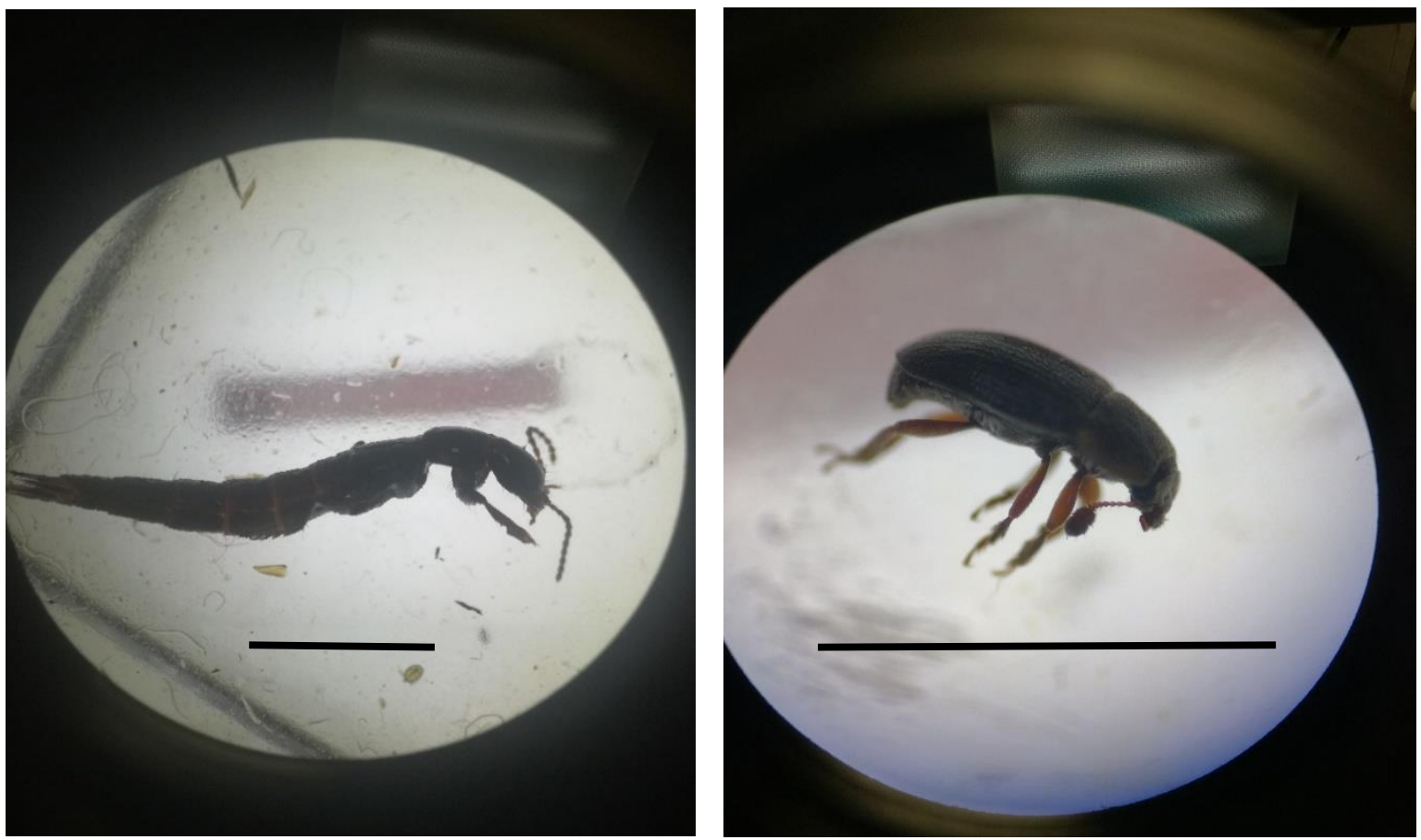

Figure 1.6 Beetles caught in pitfall traps Staphylinidae (Staphylinidae sp1) (left) and other beetles (Thalycrodes australis) (right). Scale bar $=5 \mathrm{~mm}$. 


\subsubsection{Wētā}

Wētā were identified as either ground wētā (Hemiandrus spp) or cave wētā (Rhaphorophoridae). Most ground wētā were Hemiandrus pallitarsis, however two individuals were identified as a different species the Cook Strait ground wētā or "wine wētā" Hemiandrus bilobatus. Both specimens were female and identified by the difference in the shape of the secondary copulatory organ found on the abdomen, the corresponding organ for $H$. pallitarsis this is visible in Figure 1.7.
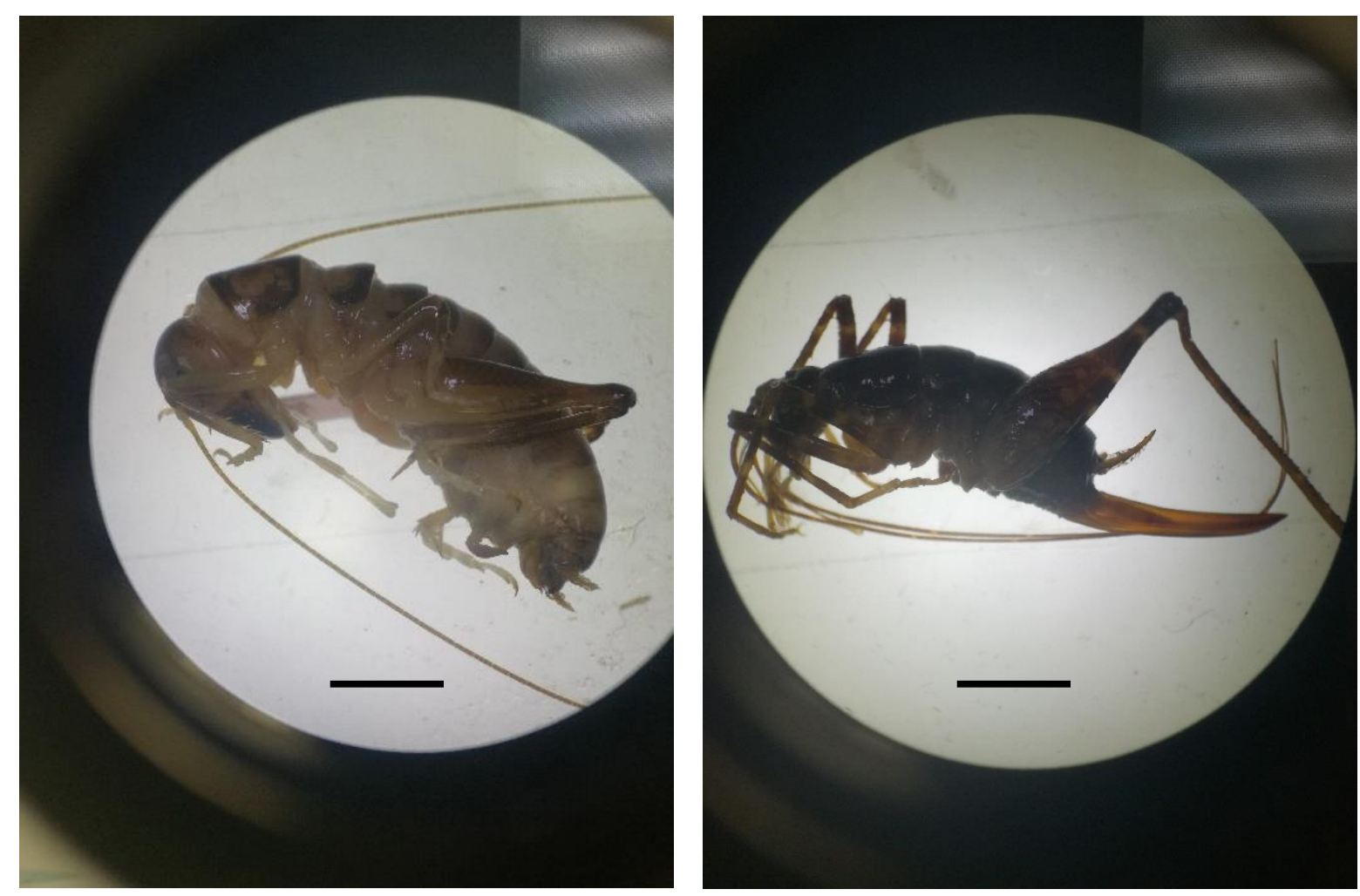

Figure 1.7 Wētā caught in pitfall traps, (Hemiandrus pallitarsis) left and Cave wētā (Family: Raphophoridae) (right). Scale bar $=5 \mathrm{~mm}$

Table 1.3 Ground dwelling wētā mean size and sample size

\begin{tabular}{|c|c|c|c|}
\hline Ground dwelling wētā (Orthoptera) & Mean size (mm) & $\begin{array}{l}\text { Interquartile body } \\
\text { size }\left(25^{\text {th }} \text { to }{75^{\text {th }}}^{\text {percentile })}\right.\end{array}$ & Sample size \\
\hline Cave wētā (Family: Rhaphophoridae) & 11.6 & $8-15$ & 515 \\
\hline Hemiandrus spp (ground wētā) & 18.6 & $11-24$ & 1207 \\
\hline Male Hemiandrus & 22.5 & $21-24$ & 442 \\
\hline Female Hemiandrus & 26.0 & $24-28$ & 293 \\
\hline Juvenile Hemiandrus & 10.2 & $7-15$ & 460 \\
\hline
\end{tabular}


Table 1.4 Cavity dwelling wētā mean size and sample size

Cavity dwelling wētā (Orthoptera)
Mean size (mm)

\section{Interquartile}

body size $\left(25^{\text {th }}\right.$ to

$7^{\text {th }}$ percentile)

Hemedeina crassidens (tree wētā)

Male Hemedeina crassidens

Female Hemedeina crassidens

Cave wētā (Family: Rhaphophoridae)
38.5

39.8

14.9
24-38

$28-42$

6-14

\begin{tabular}{|lll}
38.2 & $24-38$ & 731 \\
38.5 & $24-38$ & 317 \\
39.8 & $28-42$ & 372 \\
14.9 & $6-14$ & 159 \\
\hline
\end{tabular}

\begin{tabular}{|lll}
38.2 & $24-38$ & 731 \\
38.5 & $24-38$ & 317 \\
39.8 & $28-42$ & 372 \\
14.9 & $6-14$ & 159 \\
\hline
\end{tabular}

Sample size 


\section{Ground dwelling Coleoptera}

\subsection{Results II - Coleoptera responses}

\subsubsection{Body size}

The linear mixed effects models testing the effect of mammal index on average beetle body size showed some significant effects at the significance level $\mathrm{P}<0.01$ (Table 2.1). The strongest effect was for Carabidae which were estimated to be $3.9 \mathrm{~mm}$ larger for a hedgehog index of one relative to an index of zero $(\mathrm{P}<0.001)$. Hedgehog tracking did not exceed 0.6 across any site/line combination therefore the $3.9 \mathrm{~mm}$ estimate is a projection only. Despite the significance, the conditional $\mathrm{R}^{2}$ value for the carabid model was 0.13 suggesting that a very small proportion of the overall variation in carabid size was accounted for by the model variables. The extent of the data spread can be seen in Figure 2.1 with carabid size ranging from 4 to $30 \mathrm{~mm}$.

The other beetle category showed a significant response to rats with an estimated $1.5 \mathrm{~mm}$ increase in size $(\mathrm{P}=0.009)$ predicted to occur with abundant rats, the conditional $\mathrm{R}^{2}$ in this model, as with Carabids, was relatively low at 0.17 . This again suggests that the model is only able to account for a small proportion of the overall variability in beetle size. This becomes obvious when plotted as seen in Figure 2.2. It appears that the strength of this effect is stronger for carabids trapped in February and caught in pitfall traps without squid bait. Carabids from pitfall traps baited with squid appeared to show the opposite effect with a decrease in average size predicted with an increase in rats, whilst carabids trapped in November showed a similar but weaker trend. Scarabaeidae also showed a relationship with both mice and hedgehogs in the time delay (T-1) model. In both instances Scarabaeidae were estimated to be slightly smaller, around $0.3 \mathrm{~mm}$ for mice $(\mathrm{P}=0.002)$ (Figure 2.3) and $0.7 \mathrm{~mm}$ for hedgehogs $(\mathrm{P}<0.001)$ (Figure 2.4). The $\mathrm{R}^{2}$ value was very small in this model with the conditional $\mathrm{R}^{2}$ value limited to 0.05 suggesting that model variables were responsible for a negligible amount of observed variation.

\subsubsection{Pitfall catch}

Whilst a few significant results were found for mammal indices affecting beetle size, there were several significant results with beetle catch and mammal tracking. Increased rat tracking 
produced the most consistent declines in beetle catch with all four of the groupings with a sample size >100 (Carabidae, Scarabaeidae, Staphylinidae and other beetles) showing declines in catch summarised in Table 2.2. These estimates were highly statistically significant $(\mathrm{P}<0.001)$ providing strong evidence of an overall negative effect of introduced rats on beetle populations. The magnitude of these declines ranged from a $44.4 \%$ decrease in Scarabaeidae to an $78.0 \%$ decrease in Staphylinidae (Figure 2.5). Models for these taxa varied greatly in overall fit with Carabidae showing a modest (0.26) conditional $\mathrm{R}^{2}$ value relative to Scarabaeidae which had a high (0.98) value, suggesting that the model predictors accounted for most of the overall variation in Scarabaeidae catch. By contrast Staphylinidae and other beetles showed very low ( $0.02 \& 0.04$ respectively) conditional $\mathrm{R}^{2}$ values suggesting far greater model variability. These trends continued to be seen in the T-1 models, although Staphylinidae were no longer significantly impacted at the $<0.01$ level. The effect at this time-lag was estimated to be greater for Carabidae and Scarabaeidae which were estimated to decline by a greater amount than in the original T-0 model with the estimates increasing from a $63.1 \%$ decline for Carabidae and a $44.4 \%$ decline for Scarabaeidae to a $90.5 \%$ and $74.8 \%$ decline respectively. The conditional $\mathrm{R}^{2}$ value for carabids was also higher in the T-1 model than in the T-0 model ( 0.31 vs 0.26$)$ indicating greater explanatory power. Other beetles showed similar estimates, significance and $\mathrm{R}^{2}$ in both models.

There was also a highly significant negative effect of mice on Carabidae and Scarabaeidae. Increasing the mouse index from zero to one was estimated to reduce carabid catch by $58.8 \%$ $(\mathrm{P}<0.001)$ and Scarabaeidae catch by $40.6 \%$ (Figure 2.6). An almost significant result was found for the effect of mice on other beetles $(\mathrm{P}=0.11)$. No significant results were found in the T-1 model although weak negative correlations were seen for carabids and other beetles $(\mathrm{P}>0.01)$.

Significant changes in beetle catch were also predicted to occur with increased hedgehog tracking. These predictions were for increases in the catch of Carabidae and Scarabaeidae with an estimated increase of $236 \%$ for carabids $(\mathrm{P}<0.001)$ and $154.1 \%$ for scarabs $(\mathrm{P}<0.001)$. An estimated $96 \%$ decrease in the catch of other beetles was also predicted by the model $(\mathrm{P}<0.001)$. No response was detected in the T-1 model with neither carabids, scarabs nor other beetles showing significant responses at the $<0.01$ level. Conditional $\mathrm{R}^{2}$ values were significantly larger than marginal $\mathrm{R}^{2}$ values particularly in the GLMM abundance models indicting that random effects (Site \& Forest) explained a significant proportion of the overall model variation. 
Table 2.1 LMER model and ANOVA type 3 estimates (Pr(>Chisq)) for the effect on beetle size of an increase in mammal tracking from 0 to 1 within the current and previous (T-1) seasons, while controlling for Season and squid bait (effects not shown). Random effects were site nested within forest. Each row is a model with a different beetle family as the response variable and the mammal index of each species as additive predictor variables. $* \mathrm{P}<0.05, * *=\mathrm{P}<0.001$, ***=P $<0.001$. Arrows indicate the direction of results deemed statistically significant at the $\mathrm{P}<0.01$ level.

\begin{tabular}{|c|c|c|c|c|c|c|c|c|c|c|c|c|c|c|c|}
\hline \multirow[t]{2}{*}{ Size } & \multicolumn{4}{|l|}{ Rats } & \multicolumn{4}{|l|}{ Mice } & \multicolumn{7}{|c|}{ Hedgehog } \\
\hline & $\beta(\mathbf{m m})$ & SE & t-value & $\operatorname{Pr}(>$ Chisq $)$ & $\beta(\mathbf{m m})$ & SE & t-value & $\operatorname{Pr}(>$ Chisq $)$ & $\beta(\mathbf{m m})$ & SE & t-value & $\operatorname{Pr}(>$ Chisq $)$ & Marginal $\mathbf{R}^{2}$ & Conditional $\mathbf{R}^{2}$ & Sample size \\
\hline Carabidae & 0.2 & 0.5 & 0.5 & 0.648 & -0.5 & 1.1 & -0.4 & 0.658 & $\uparrow 3.9$ & 0.9 & 4.1 & $<0.001 * * *$ & 0.04 & 0.13 & 1310 \\
\hline Scarabaeidae & 0.1 & 0.1 & 2.0 & $0.045^{*}$ & -0.1 & 0.1 & -0.6 & 0.520 & -0.1 & 0.1 & -1.0 & 0.341 & 0.01 & 0.04 & 1811 \\
\hline Staphylinidae & 2.1 & 1.1 & 1.9 & 0.056 & 0.1 & 1.2 & 0.1 & 0.950 & 1.3 & 2.9 & 0.4 & 0.665 & 0.13 & 0.29 & 271 \\
\hline Other beetles & $\uparrow 1.5$ & 0.6 & 2.6 & $0.009 * *$ & -0.2 & 0.7 & -0.2 & 0.830 & -0.1 & 1.3 & -0.0 & 0.967 & 0.06 & 0.17 & 416 \\
\hline \multirow[t]{2}{*}{ Size T-1 } & \multicolumn{4}{|c|}{ Rats (T-1) } & \multicolumn{4}{|c|}{ Mice (T-1) } & \multicolumn{7}{|c|}{ Hedgehogs (T-1) } \\
\hline & $\beta(\mathbf{m m})$ & SE & t-value & $\operatorname{Pr}(>$ Chisq $)$ & $\beta(\mathbf{m m})$ & SE & t-value & $\operatorname{Pr}(>$ Chisq) & $\beta(\mathbf{m m})$ & SE & t-value & $\operatorname{Pr}(>$ Chisq $)$ & Marginal $\mathbf{R}^{2}$ & Conditional $\mathbf{R}^{2}$ & Sample size \\
\hline Carabidae & -1.4 & 0.6 & -2.3 & $0.023 *$ & -1.5 & 1.1 & -1.5 & 0.313 & -1.8 & 1.5 & -1.2 & 0.241 & 0.04 & 0.11 & 1158 \\
\hline Scarabaeidae & -0.1 & 0.1 & -1.5 & 0.145 & $\uparrow-0.3$ & 0.1 & -3.2 & $0.002 * *$ & $\downarrow-0.7$ & 0.1 & -4.7 & $<0.001 * * *$ & 0.02 & 0.05 & 1794 \\
\hline Staphylinidae & -0.9 & 1.2 & -0.7 & 0.465 & 0.4 & 1.2 & 0.3 & 0.769 & -1.4 & 2.8 & -0.5 & 0.622 & 0.12 & 0.27 & 254 \\
\hline Other beetles & 1.4 & 0.7 & 2.1 & $0.037 *$ & 1.5 & 1.2 & 1.3 & 0.204 & 3.5 & 1.8 & 1.9 & 0.054 & 0.06 & 0.20 & 382 \\
\hline
\end{tabular}

Table 2.2 GLMM model estimates for the effect on beetle catch of an increase in mammal index from 0 to 1 in the current and previous (T-1) season, while controlling for season and squid bait. Random effects were site nested within forest. Sample size was 1936 pitfalls, number of individual beetles caught is the same as for corresponding LMER models shown in Table 2.1. Each row is a model with a different beetle family as the response variable and the mammal index of each species as additive predictor variables. $* \mathrm{P}<0.05, * *=\mathrm{P}<0.001, * * *=\mathrm{P}<0.001$. Arrows indicate the direction of results deemed statistically significant at the $\mathrm{P}<0.01$ level.

\begin{tabular}{|c|c|c|c|c|c|c|c|c|c|c|c|c|c|c|c|c|c|}
\hline \multirow[t]{2}{*}{ Abundance } & \multicolumn{5}{|l|}{ Rats } & \multicolumn{5}{|l|}{ Mice } & \multicolumn{7}{|c|}{ Hedgehog } \\
\hline & $\boldsymbol{\beta}$ & $\begin{array}{l}\text { Estimate } \\
(\%)\end{array}$ & $\mathbf{S E}$ & Z-value & $\operatorname{Pr}(>$ Chisq) & $\boldsymbol{\beta}$ & $\begin{array}{l}\text { Estimate } \\
(\%)\end{array}$ & $\mathbf{S E}$ & Z-value & $\operatorname{Pr}(>$ Chisq $)$ & $\beta$ & $\begin{array}{l}\text { Estimate } \\
(\%)\end{array}$ & SE & Z-value & $\operatorname{Pr}(>$ Chisq) & $\begin{array}{l}\text { Marginal } \\
\mathbf{R}^{2} \\
\end{array}$ & $\begin{array}{l}\text { Conditional } \\
\mathbf{R}^{2} \\
\end{array}$ \\
\hline Carabidae & $\downarrow-1.00$ & -63.1 & 0.36 & -9.04 & $<0.001 * * *$ & $\downarrow-0.89$ & -58.8 & 0.22 & -4.05 & $<0.001 * * *$ & $\uparrow 1.22$ & 236.0 & 0.19 & 6.41 & $<0.001 * * *$ & 0.07 & 0.26 \\
\hline Scarabaeidae & $\downarrow-0.59$ & -44.4 & 0.08 & -7.28 & $<0.001 * * *$ & $\downarrow-0.52$ & -40.6 & 0.13 & -4.03 & $<0.001 * * *$ & $\uparrow 0.97$ & 164.1 & 0.13 & -4.03 & $<0.001 * * *$ & 0.23 & 0.98 \\
\hline Staphylinidae & $\downarrow-1.52$ & -78.0 & 0.27 & -5.68 & $<0.001 * * *$ & 0.12 & 13.3 & 0.34 & 0.37 & 0.714 & -1.15 & -68.3 & 0.59 & -1.96 & $0.050 *$ & 0.01 & 0.02 \\
\hline Other beetles & $\downarrow-1.47$ & -77.0 & 0.22 & -6.53 & $<0.001 * * *$ & -0.90 & 59.5 & 0.36 & -2.54 & $0.011 *$ & $\downarrow-3.21$ & -96.0 & 0.49 & -6.49 & $<0.001 * * *$ & 0.03 & 0.04 \\
\hline \multirow[t]{2}{*}{ Abundance T-1 } & \multicolumn{5}{|c|}{ Rats (T-1) } & \multicolumn{5}{|c|}{ Mice (T-1) } & \multicolumn{7}{|c|}{ Hedgehog (T-1) } \\
\hline & B & $\begin{array}{l}\text { Estimate } \\
(\%)\end{array}$ & SE & Z-value & $\operatorname{Pr}(>$ Chisq $)$ & $\beta$ & $\begin{array}{l}\text { Estimate } \\
(\%)\end{array}$ & $\mathbf{S E}$ & Z-value & $\operatorname{Pr}(>$ Chisq $)$ & $\beta$ & $\begin{array}{l}\text { Estimate } \\
(\%)\end{array}$ & SE & Z-value & $\operatorname{Pr}(>$ Chisq) & $\begin{array}{l}\text { Marginal } \\
\mathbf{R}^{2} \\
\end{array}$ & $\begin{array}{l}\text { Conditional } \\
\mathbf{R}^{2} \\
\end{array}$ \\
\hline Carabidae & $\downarrow-2.36$ & -90.5 & 0.14 & -16.96 & $<0.001 * * *$ & -0.64 & -47.5 & 0.28 & -2.29 & $0.022 *$ & 0.79 & 120.9 & 0.32 & 2.50 & $0.013 *$ & 0.13 & 0.31 \\
\hline Scarabaeidae & $\downarrow-1.38$ & -74.8 & 0.10 & -14.39 & $<0.001 * * *$ & -0.22 & -20.1 & 0.14 & -1.64 & 0.102 & -0.55 & -42.4 & 0.24 & -2.32 & $0.021 *$ & 0.22 & 0.98 \\
\hline Staphylinidae & -0.69 & -49.9 & 0.29 & -2.42 & $0.016^{*}$ & -0.00 & 0.3 & 0.37 & -0.01 & 0.993 & -0.91 & -59.7 & 0.89 & -1.02 & 0.306 & 0.03 & 0.07 \\
\hline Other beetles & $\downarrow-1.72$ & -82.1 & 0.24 & -7.10 & $<0.001 * * *$ & -1.07 & -65.6 & 0.45 & -2.35 & $0.019^{*}$ & -1.20 & -70.0 & 0.64 & -1.89 & 0.059 & 0.03 & 0.03 \\
\hline
\end{tabular}



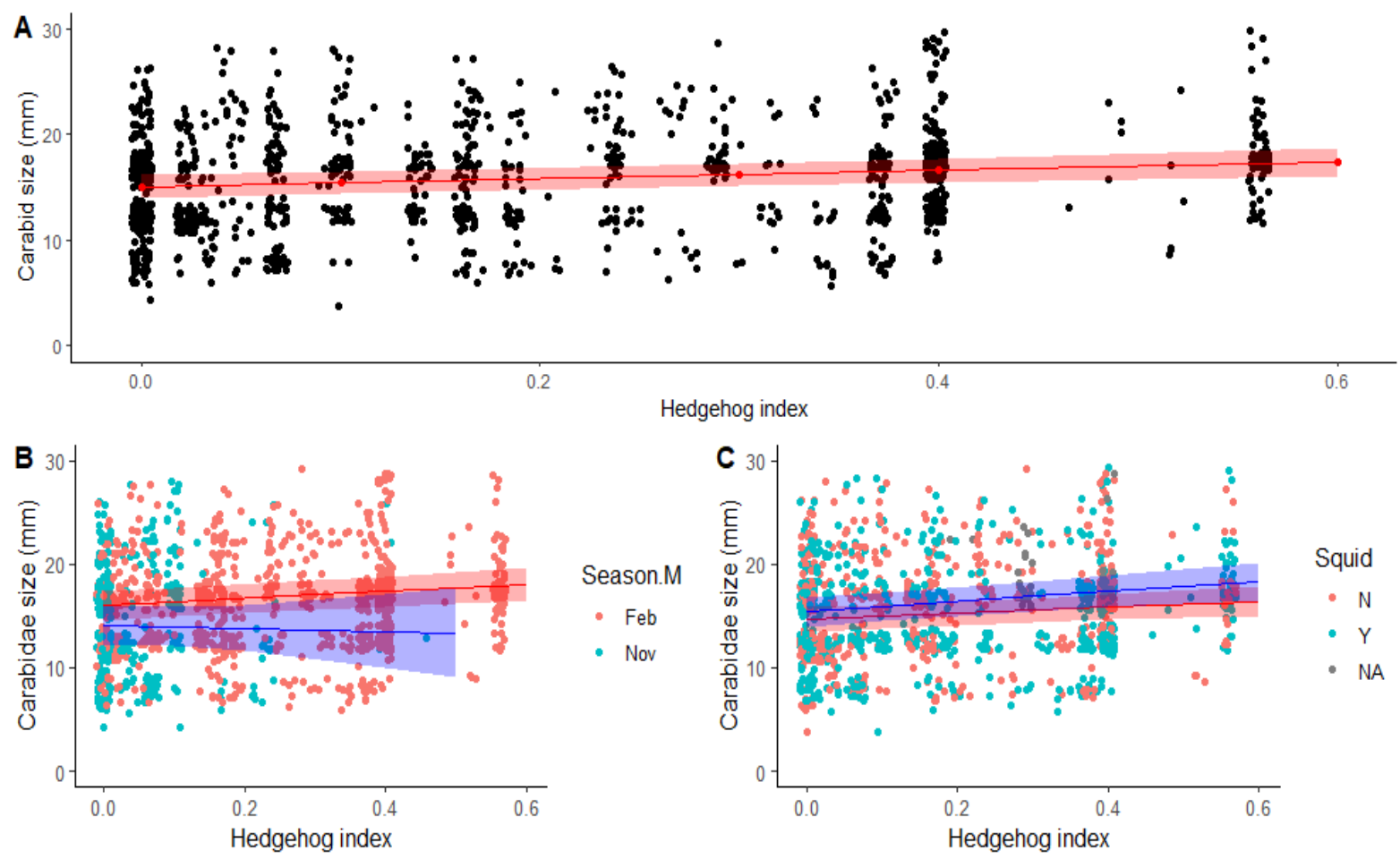

Figure 2.1 Carabidae size $(\mathrm{mm})$ and hedgehog index (A) by season (B) and squid baiting (C), each point represents an individual beetle, points have been jittered to allow for easier visualisation of data clusters. The $\mathrm{x}$-axis was limited to $30 \mathrm{~mm}$ omitting 6 observations. Lines and ribbons indicate model estimates and 95\% confidence intervals
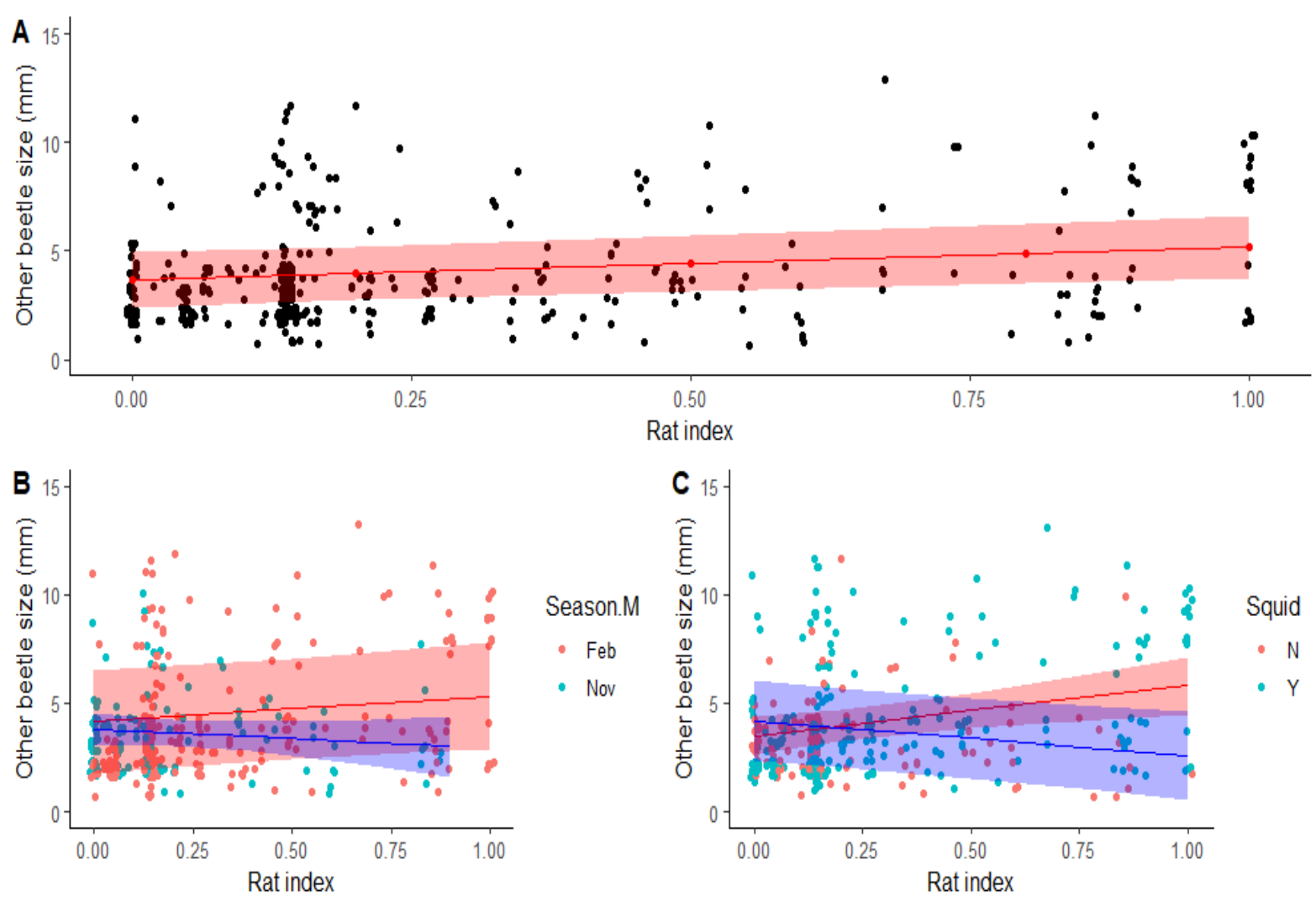

Figure 2.2 Other beetle size ( $\mathrm{mm}$ ) and rat index (A) by season (B) and squid baiting (C), each point represents an individual beetle, points have been jittered to allow for easier visualisation of data clusters. The $\mathrm{x}$-axis was limited to $15 \mathrm{~mm}$ omitting 2 observations. Lines and ribbons indicate model estimates and $95 \%$ confidence intervals. 

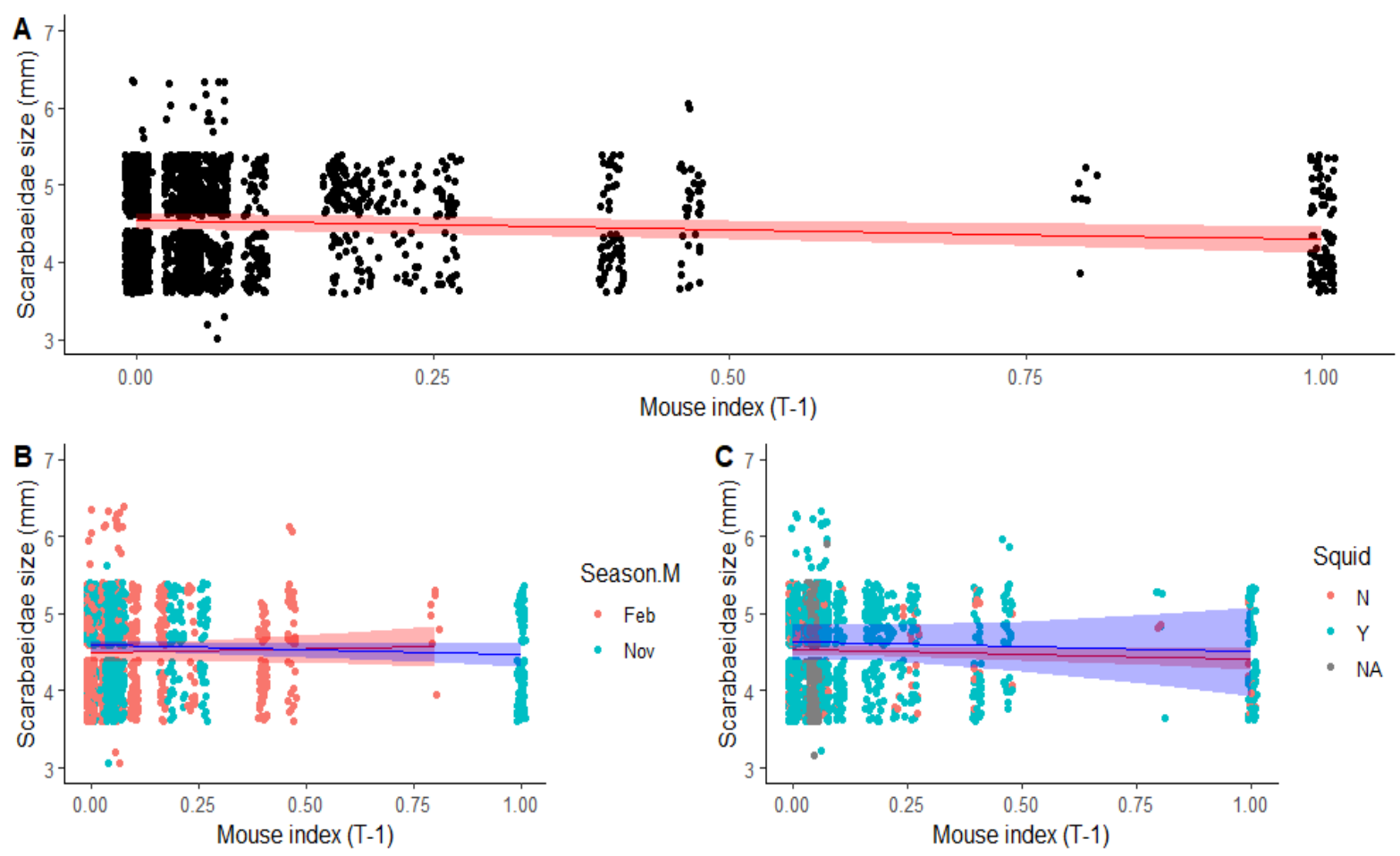

Figure 2.3 Scarabaeidae size (mm) and mouse index in the previous season (A) by season (B) and squid baiting (C), each point represents an individual beetle, points have been jittered to allow for easier visualisation of data clusters. The $\mathrm{x}$-axis was limited to $7 \mathrm{~mm}$ omitting 9 observations. Lines and ribbons indicate model estimates and $95 \%$ confidence intervals.
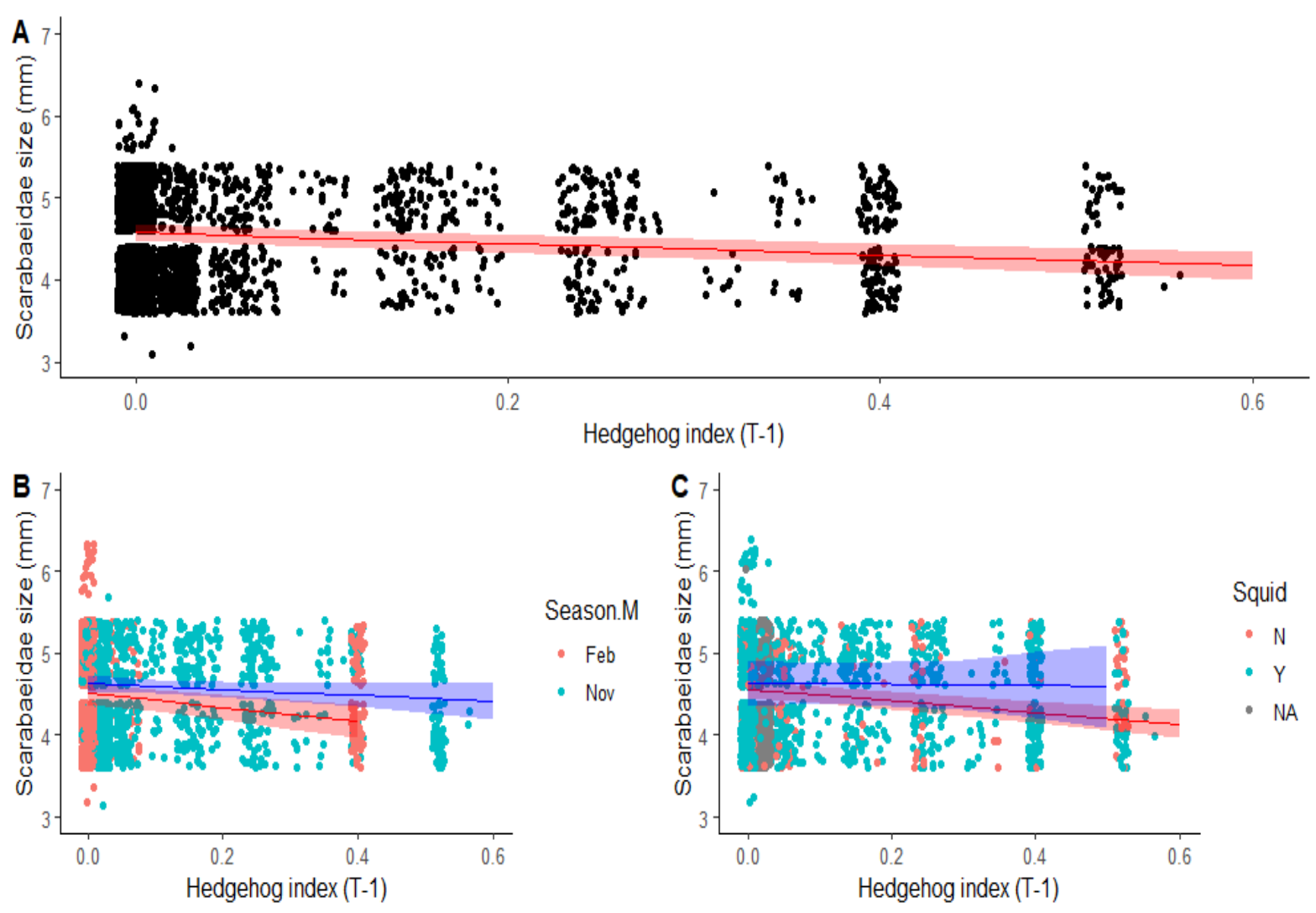

Figure 2.4 Scarabaeidae size (mm) and hedgehog index in the previous season (A) by season (B) and squid baiting (C), each point represents an individual beetle, points have been jittered to allow for easier visualisation of data clusters. The $\mathrm{x}$-axis was limited to $7 \mathrm{~mm}$ omitting 9 observations. Lines and ribbons indicate model estimates and $95 \%$ confidence intervals. 

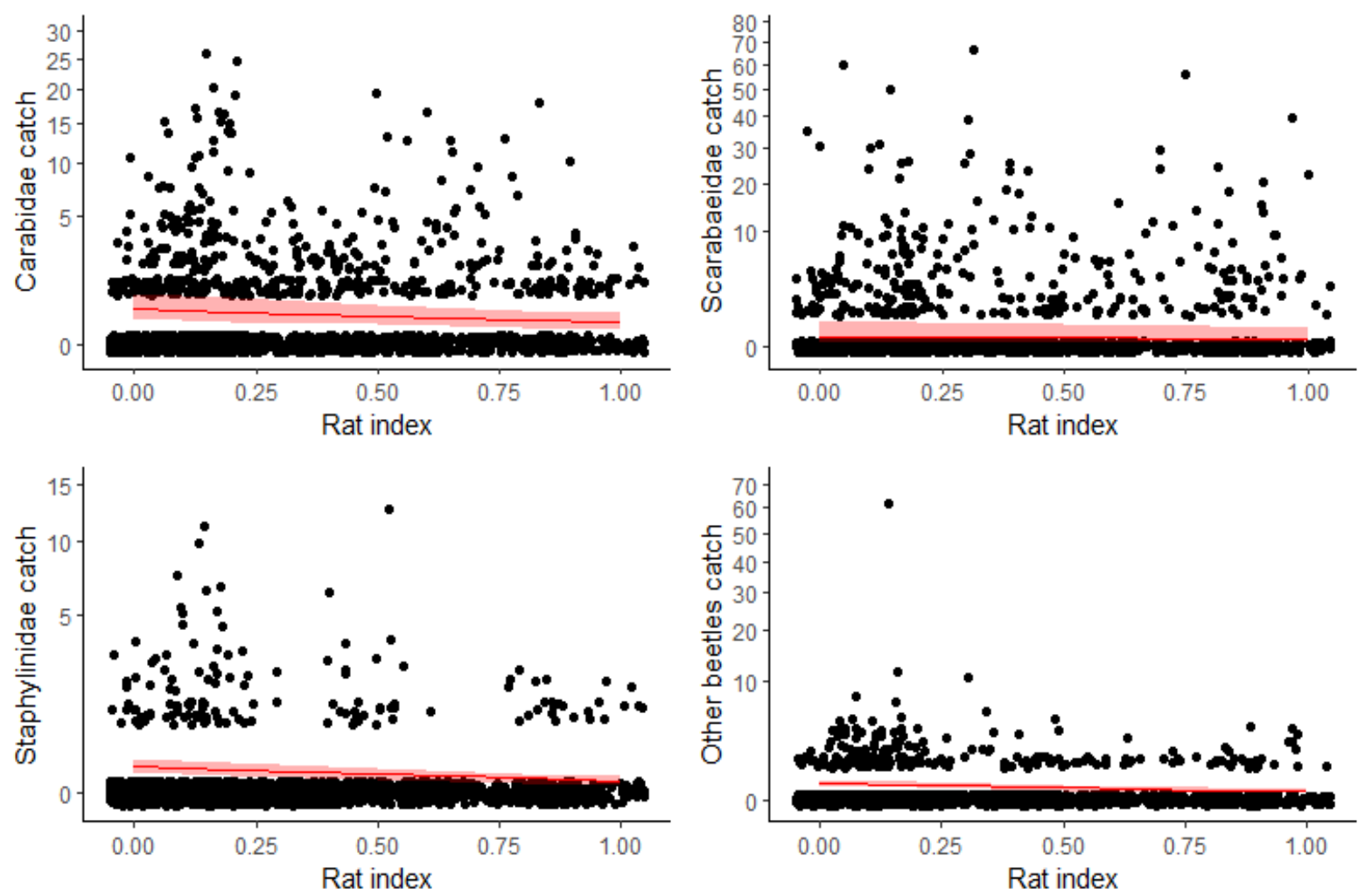

Figure 2.5 GLMM model estimates of the effect of an increase in rat index from 0 to 1 , on the beetle pitfall catch by family including 95\% confidence intervals. Individual data points indicate the catch in an individual pitfall, points have been randomly jittered and square root transformed to allow for easier data visualisation, y axis values have been back transformed to raw pitfall catch values. Significant $(\mathrm{P}<0.01)$ model predictions are shown in red.
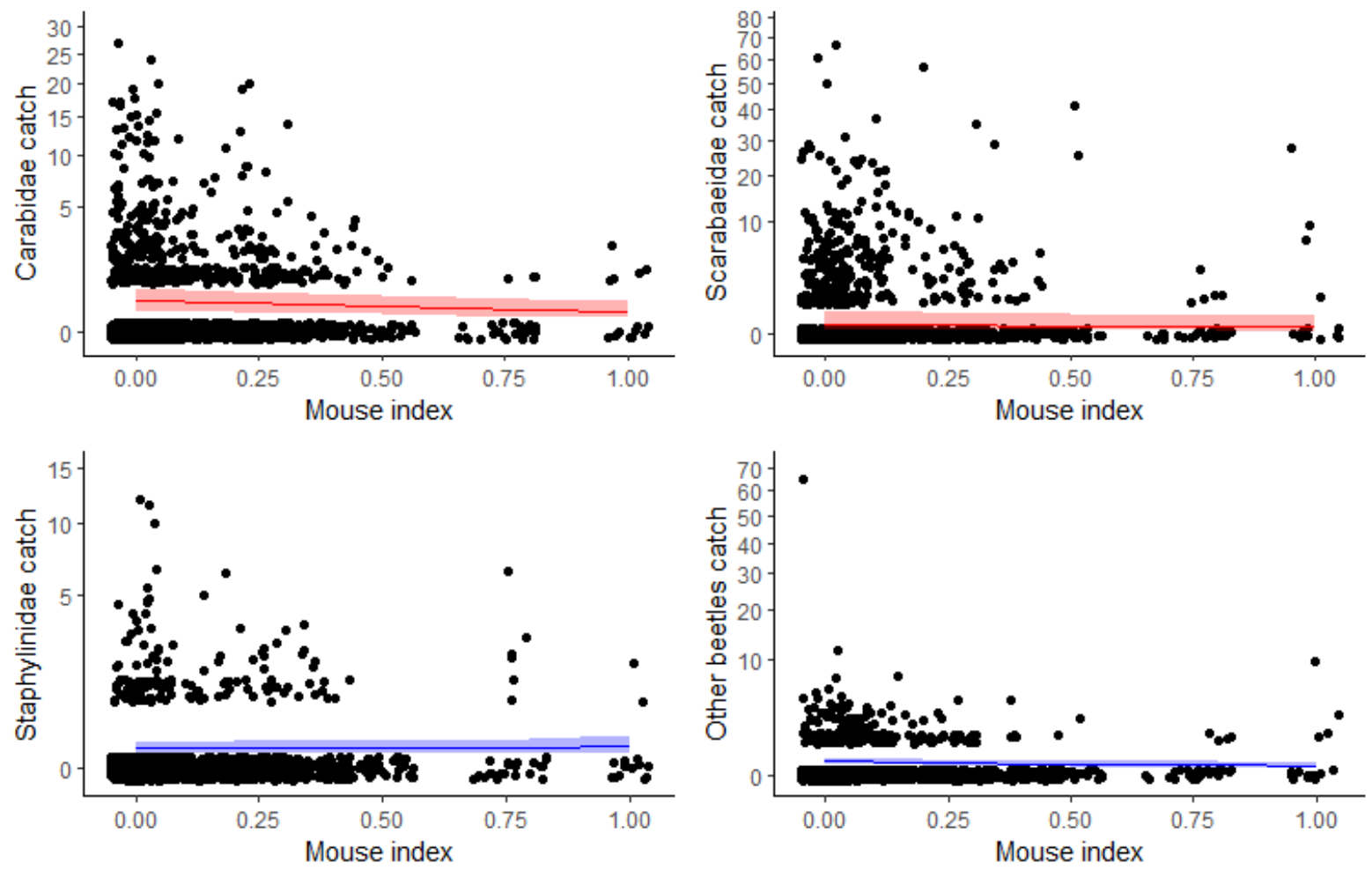

Figure 2.6 GLMM model estimates of the effect of an increase in mouse index from 0 to 1 on beetle pitfall catch by family including 95\% confidence intervals. Individual data points indicate the catch in an individual pitfall, points have been randomly jittered and square root transformed to allow for easier data visualisation, y axis values have been back transformed to raw pitfall catch values. Significant $(\mathrm{P}<0.01)$ model perdictions are shown in red. 

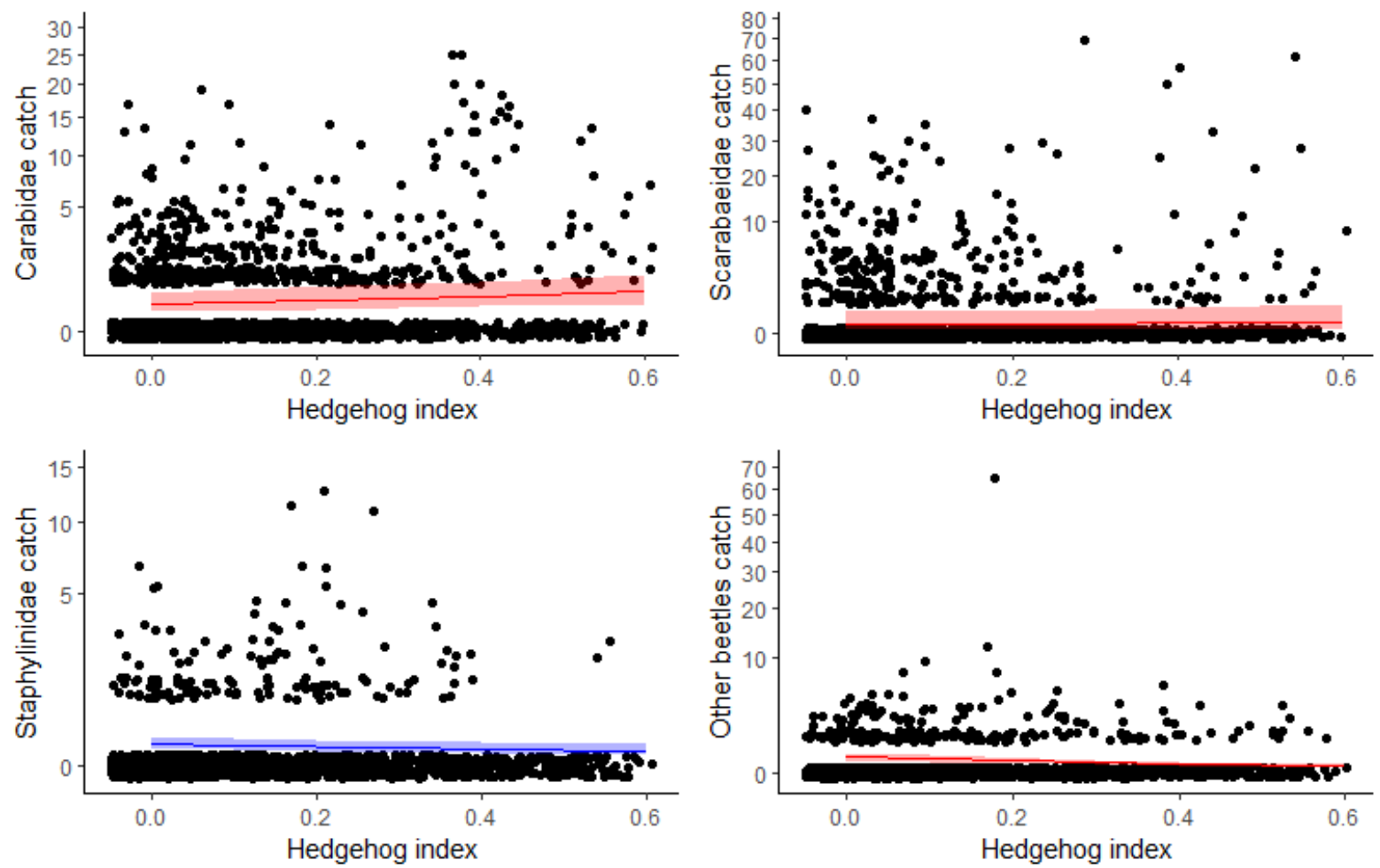

Figure 2.7 GLMM model estimates of the effect of an increase in hedgehog index from 0 to 1 and beetle pitfall catch by family including 95\% confidence intervals. Individual data points indicate the catch in an individual pitfall, points have been randomly jittered and square root transformed to allow for easier data visualisation, y axis values have been back transformed to raw pitfall catch values. Significant $(\mathrm{P}<0.01)$ model predictions are shown in red.
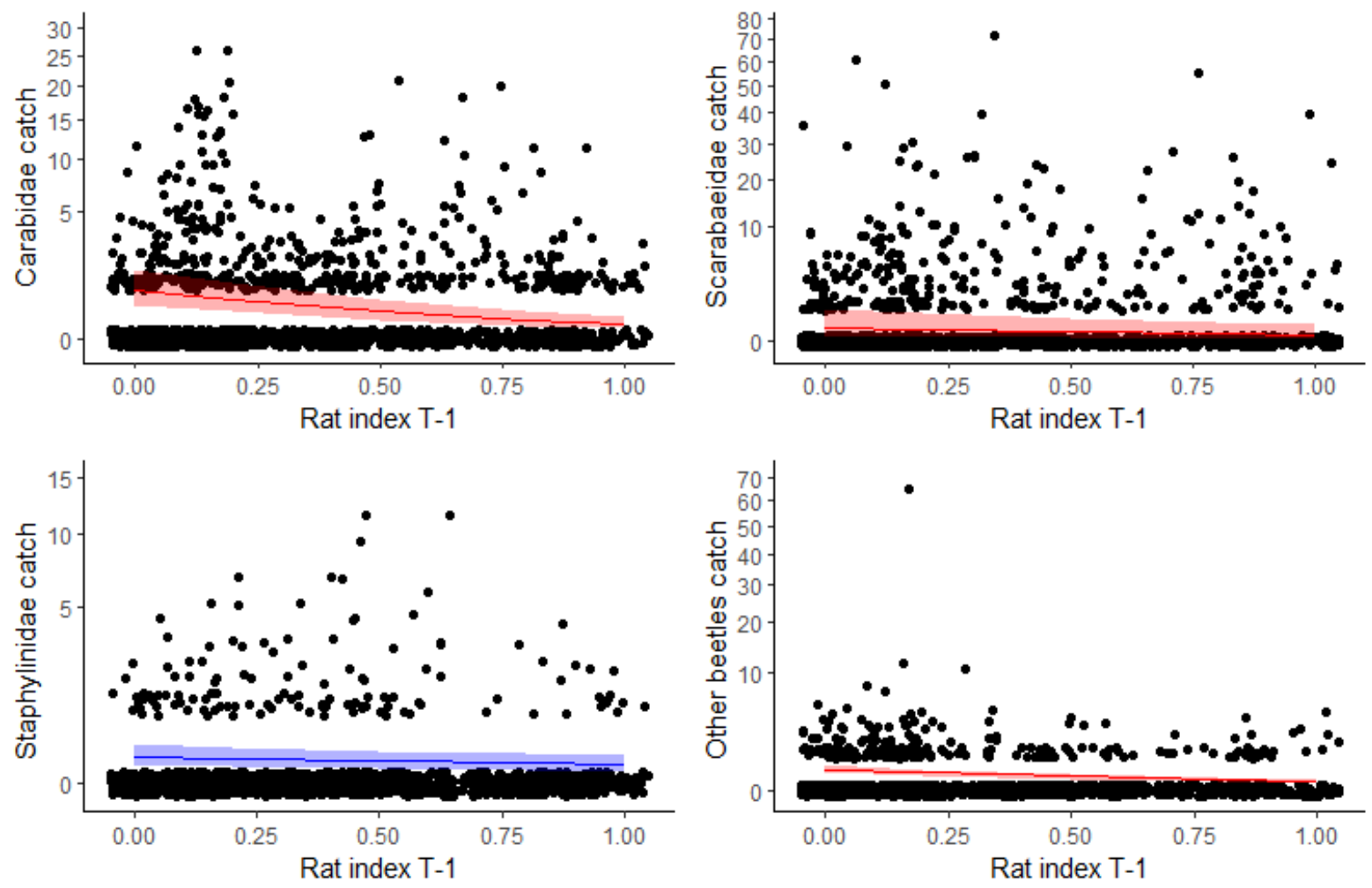

Figure 2.8 GLMM model estimates of the effect of an increase in rat index from 0 to1 in the previous season on beetle pitfall catch by family including $95 \%$ confidence intervals. Individual data points indicate the catch in an individual pitfall, points have been randomly jittered and square root transformed to allow for easier data visualisation, y axis values have been back transformed to raw pitfall catch values. Significant $(\mathrm{P}<0.01)$ model predictions are shown in red. 

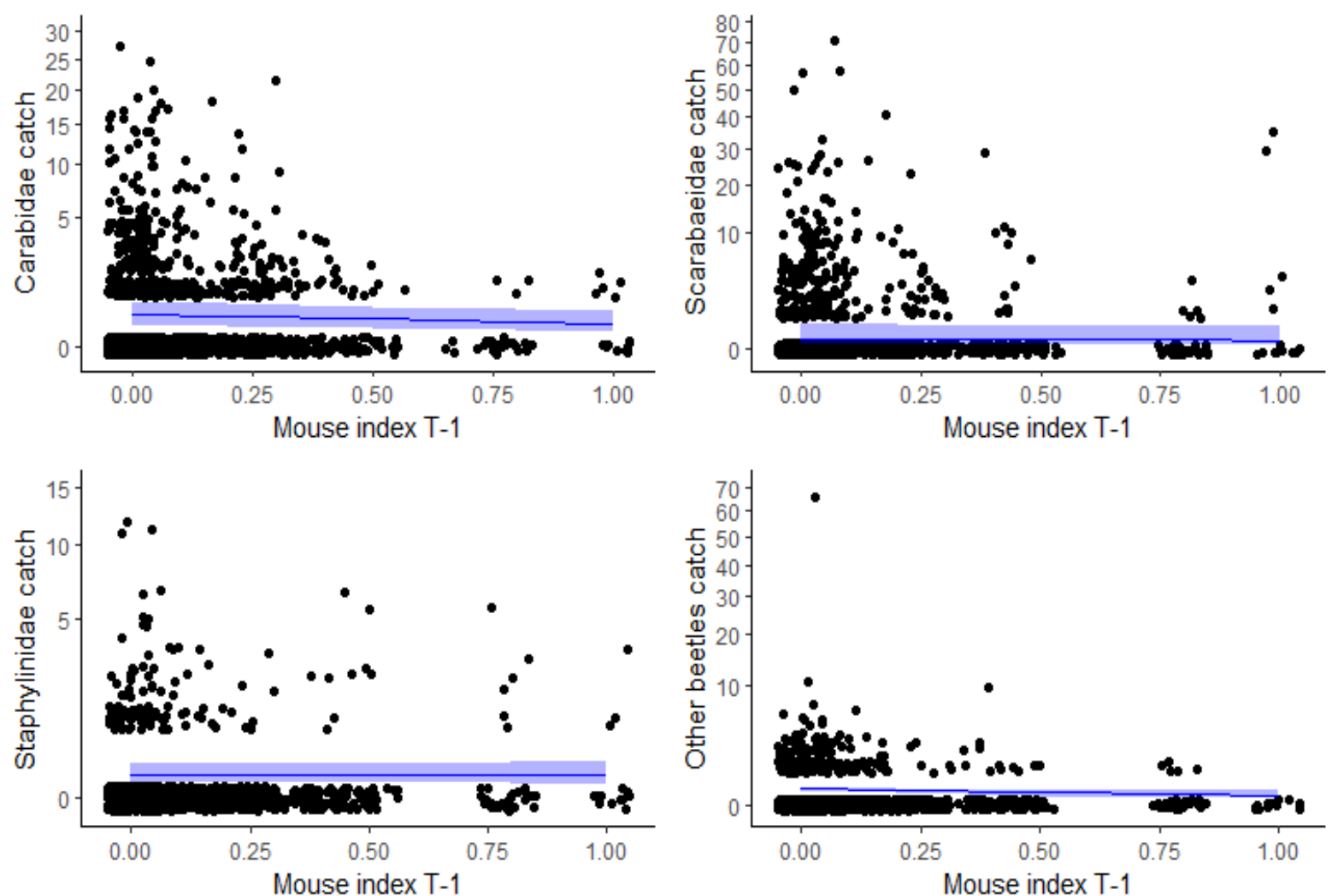

Figure 2.9 GLMM model estimates for the effect of an increase in mouse tracking in the previous season from 0 to 1 on beetle pitfall catch by family including $95 \%$ confidence intervals. Individual data points indicate the catch in an individual pitfall, points have been randomly jittered and square root transformed to allow for easier data visualisation, y axis values have been back transformed to raw pitfall catch values.
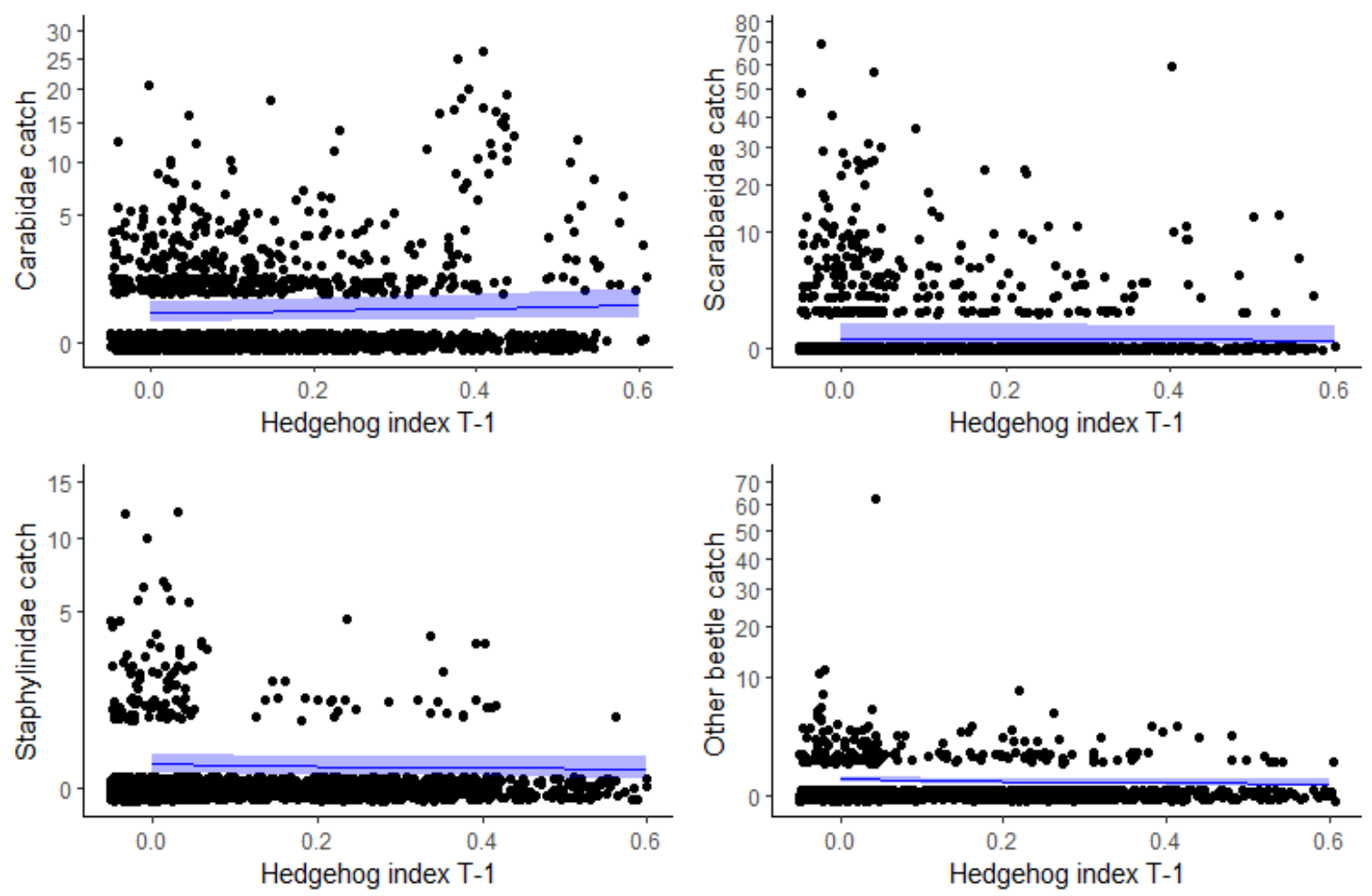

Figure 2.10 GLMM model estimates for the effect of an increase in hedgehog index in the previous season from 0 to 1 on beetle pitfall catch by family including $95 \%$ confidence intervals. Individual data points indicate the catch in an individual pitfall, points have been randomly jittered and square root transformed to allow for easier data visualisation, y axis values have been back transformed to raw pitfall catch values. 


\subsection{Discussion}

Although the effect of mammals on the size and abundance of Carabidae, Scarabaeidae, Staphylinidae and other beetles varied from taxa to taxa and predator to predator there were some consistent trends. Most significantly, increased rat abundance was associated with lower catch rates for all four main beetle groupings to a high degree of statistical significance. Most of these results remained significant when using the previous season's rat index, recorded three to four months prior (T-1). Similar results were found for mice although the associations were weaker and applied only to Carabidae and Scarabaeidae within the current season (T-0). Surprisingly, increased hedgehog tracking was associated with an increased Carabidae and Scarabaeidae catch, indicating diverse responses from invertebrates depending on the specific mammal predators.

These results seem to support the findings of other studies which have found increases in beetle abundance in response to the eradication of mammals from fenced ecosanctuaries (Watts et al., 2020) and provide evidence that invertebrates are negatively impacted by introduced rats and mice in mainland environments. Although this result is to be expected, comparable studies have often shown ambiguous responses in beetle communities in response to increased rat predation and there are examples of increases, decreases and stable invertebrate populations found in the literature (Craddock, 1997; Rate, 2009; Watts et al., 2011; Watts et al., 2020; Watts \& Thornburrow, 2009; Watts et al., 2014).

The high significance and consistency of the rat GLMM models across a range of beetle taxa gives confidence that there is an overall negative effect of rats on beetle abundance, however there is still significant variability in the model predictions. The relatively low conditional $\mathrm{R}^{2}$ values reported in the model, sometimes $<0.1$, indicate that interactions are complex and that there are a range of local environmental variables that likely effect the abundance and species composition of beetle communities more strongly than mammal predation (Watts et al., 2020). Invertebrates typically respond quickly to environmental variables such as temperature, humidity and resource availability (Dornelas \& Daskalova, 2020) making it difficult to distinguish between the effects of natural environmental fluctuations and the effects of mammal predation, especially as both can themselves be linked (Efford et al., 2006). The difficulty in disentangling different variables was demonstrated by the low conditional $\mathrm{R}^{2}$ values recorded for all beetle taxa apart from Scarabaeidae which recorded consistently high conditional $\mathrm{R}^{2}$ values $>0.95$. Conditional $\mathrm{R}^{2}$ values were typically higher than marginal $\mathrm{R}^{2}$ 
values, indicating that the random effects of site and forest are important inclusions in the mode and suggest that factors such as available habitat may be more important predictors of beetle abundance, particularly for Scarabaeidae.

Comparable natural experiments have indicated similar patterns with beetles responding far more to changes in resource availability, temperature and seasonality than to mammal predation (Hutchison, 2001; Wilmshurst \& Carpenter, 2020). Most other studies have also tended to be shorter in duration and may not have been long enough to detect changes in beetle communities in response to mammals (St Clair, 2011; Watts et al., 2014). Previous analysis using pitfall trapping from 2013-2015 in the Aorangi and Remutaka forests failed to find any significant relationships between beetle abundance and the presence of introduced mammals, demonstrating the importance of long term studies in order to sufficiently capture changes in invertebrate communities (Vergara, 2018).

The other beetle category is a diverse taxonomic group made up of mostly small beetles (interquartile body size $=2-4 \mathrm{~mm}$ ). This was the most variable beetle groups with 73 different morphospecies identified ranging from 1 to $39 \mathrm{~mm}$. The increase in the size of other beetles corresponds with a predicted decline in catch associated with increased rat numbers. This may indicate that there was a greater decline in the number of smaller beetles relative to the larger ones however, the causal pathway and whether this was a result of direct rat predation, is unclear.

An increase in mouse index was only significantly predictive of an increase in the size of Scarabaeidae in the following season. There was however a strong negative association between mice and the overall catch of Carabidae, Scarabaeidae within the current season. The impact of mice was limited to Carabidae and Scarabaeidae, whilst rats also impacted on Staphylinidae and other beetles. This may reflect the large samples sizes of Carabidae and Scarabaeidae which were both greater than 1000 individuals from 1936 pitfalls. It may also reflect the generally lower mouse index recorded throughout the study which may have prevented significant results being found for Staphylinidae and other beetles. The effect of mice on Carabidae and Scarabaeidae mirrors the results of several other studies which have found fewer beetles in areas with abundant mice (Russell et al., 2020; Watts et al., 2020; Watts et al., 2014). Mice are known to preferentially predate on invertebrates when they are abundant, 
this is thought to be true particularly in summer where invertebrates are typically more numerous and there is a greater abundance of larvae (Russell et al., 2020).

The original hypothesis for this study outlined in Chapter One was that larger invertebrates would be more vulnerable and therefore there would likely be more negatively impacted. If this were true, average beetle size would be expected to decrease in the presence of abundant mammals and/or there would be a decrease abundance of the larger taxa. However, the beetle family with the largest average body size (carabids) showed no evidence of size selective pressure in response to rats or mice and an increase in size in response to hedgehogs. It could also be the case that although larger taxa are more vulnerable, they are not equally vulnerable at all periods of their lifecycle and so may not show changes in size within species or familial groups. The declines in catch rates in response to rats appeared similar for all familial groups indicating a similar response from invertebrates to elevated rat populations.

Mice are known to significantly negatively impact populations of invertebrates on small island ecosystems where they often live without major predators, such as rats, which typically limit their numbers on the mainland (Broome et al., 2019). The mouse index was generally lower than rat index throughout this study, the mean mouse index across either forest never exceeded $40 \%$ whilst mean rat tracking reached $\sim 90 \%$. Mice are much smaller than rats and therefore their preferred prey size is also likely to be smaller, some estimates have placed this at between 3-12mm (Ruscoe, 2001), although mice have been known to preferentially predate upon larger invertebrates (Angel et al., 2009). This size preference covers the mean size of most beetle groupings in this study, of the four main groups analysed only Carabidae had a higher average size $(15.9 \mathrm{~mm})$ although there was significant variability within this group which had an interquartile range of $12-18 \mathrm{~mm}$. It was therefore interesting to observe that the largest and most significant declines in catch in response to mice were for Carabidae.

The model predictions for the effect of hedgehog tracking on the size and abundance of beetles led to some interesting findings. A significant increase in the size of carabids was estimated occur with an increase in the hedgehog tracking index, although the hedgehog index was never higher than 0.6. This is an unexpected finding as it would typically be assumed that larger beetles would be a preferred prey and therefore more vulnerable. The abundance model similarly predicted a significant increase in the catch rate of pitfall trapped carabids of $236.0 \%$ 
when hedgehog tracking increased. This suggests that not only are Carabids larger in the presence of dense hedgehog populations, but they are also more abundant.

According to the model estimates Scarabaeidae and other beetles showed a significant decline in response to hedgehogs. This was an interesting finding as it appears that all Scarabaeidae beetles $>5 \mathrm{~mm}$ in size were caught in pitfalls where hedgehog index was zero $(n=6)$. All Scarabaeidae $<5 \mathrm{~mm}$ in size were identified as Saphobius spp, so this finding may suggest an increased vulnerability of Scarabaeidae $>5 \mathrm{~mm}$ to hedgehog predation. Of the 2355 Scarbaeidae recorded in this study (including individuals not used for model construction) only six individuals belonged to a genus other than Saphobius, these were chafer beetles belonging to the genera Odontia and Sericospilus and all were $>8 \mathrm{~mm}$ in length. It is possible that the prevalence of these species reflects responses to hedgehog abundance however, it could also represent seasonal variations with five of the six chafer beetles recorded in February when hedgehog tracking is typically low. Chafer beetles are known to be predated upon by hedgehogs and some rare and endangered species of chafer such as Prodontria modesta (Alexandrai chafer) and Prodontria lewisii (Cromwell chafer) are thought to be at risk of extinction due in part to hedgehog predation (Bowie, 2008; Hamilton, 1999; Hendra, 1999; Jones et al., 2005). It is therefore possible that hedgehog predation significantly reduces the populations of these larger scarabs however sample sizes were small. Scarabaeidae catch was estimated to increase by $164.4 \%$ with the increased presence of hedgehogs. The most likely explanation for this phenomenon is that increased hedgehog tracking rates reflect an increase in hedgehog activity driven by increased invertebrate populations.

The model also predicted a $90.5 \%$ decline in the catch of other beetles when using the present season's hedgehog index. This trend was striking as there was an increase in catch for Carabidae and Scarabaeidae yet other beetles declined. As this is a highly taxonomically diverse group, there could be multiple factors contributing to this such as the increase in the presence of larger predatory invertebrates which may be suppressing smaller beetles found in the "other beetles" category. Carabids are themselves predatory beetles with a preferred prey size of $<3 \mathrm{~mm}$ and it is likely that some of the smaller beetles in the other beetle category could be potential prey items (Hutchison, 2001). Assuming increased hedgehog tracking is driven by increases in invertebrate prey rather than the effects of hedgehogs on invertebrates, then it follows that the decline in other beetles reflects a greater abundance of other competing or predatory invertebrates. 
One potential explanation for the increase invertebrate catch with hedgehog tracking is the increased activity of both groups during the warmer summer sampling periods. Hedgehogs are highly seasonal and tend to be more active in the warmer summer months typically hibernating for one to two to three months in the winter in New Zealand (Brockie, 1958). Hedgehogs are sensitive to temperature which can determine how long they remain in hibernation and is thought to impact on mortality rate particularly during cold and damp winter periods (Hendra, 1999).

Hedgehog behaviour and dietary preferences would suggest that increases in beetle could be a significant driver of increased hedgehog tracking. Unlike rats and mice which are generalist omnivores, hedgehogs are primarily insectivorous with invertebrates making up the bulk of hedgehog diets (Hendra, 1999; Nottingham et al., 2019). Beetles in particular have been found to make up a significant proportion of the diets of hedgehogs with some studies recording that 94\% of beetle scats contain beetle remains (Jones \& Norbury, 2011). Previous observations in the Orongorongo Valley have suggested that the main dietary items consumed by hedgehogs were wētā, millipedes and large centipedes (Hamilton, 1999). It is therefore possible that hedgehogs are responding to a general increase in the abundance of invertebrates which is what is presenting in the model rather than a direct linkage between the beetles and hedgehogs. High concentrations of invertebrates have been documented as hot spots for hedgehog activity in previous studies (Parkes, 1975) and this appears to be the case here. Unlike rats and mice, hedgehogs are not explicitly targeted by predator control efforts and are therefore less affected by 1080 applications as they are typically hibernating in the winter when 1080 applications usually take place. However, they may be affected by the impact on hedgehog predators such as stoats (King \& Moody, 1982). If hedgehogs were unaffected by 1080 this would likely mean that hedgehog abundance is closer to carrying capacity and therefore more likely to respond to changes in resource availability such as invertebrate abundance.

\subsubsection{Delayed impact (T-1) models}

It is difficult to assess whether the T- 0 or the T- 1 model provided a better overall prediction of the impact of mammals on invertebrate communities as significant results were achieved for both model specifications. There was little evidence of predator prey cycles occurring over the timescales examined in this study although this may be due to the insufficient time delay. More significant results were found in the T-0 model, perhaps due to the slightly larger sample size, but the $\mathrm{R}^{2}$ values across both time series were broadly comparable. Carabids were the only 
species to show a notable difference between the models with a greater conditional $\mathrm{R}^{2}$ value (0.31) recorded in the T-1 model compared with the T-0 model $(0.26)$.

\subsubsection{Relative beetle vulnerability}

Carabidae were among the largest beetles in the study and therefore represent one of the families that would hypothetically be the most vulnerable to mammalian predation. Carabidae catch was reduced by the presence of rats and mice and responded positively to hedgehog tracking, suggesting that they may be one of the most sensitive invertebrate families. Very little is known about the life histories of New Zealand carabids although carabids generally have received significant study outside of New Zealand (Hutchison, 2007). Carabids have often been used as indicator species due to their sensitivity to pollutants and habitat modification (Lovei \& Sunderland, 1996), but it is not known how suitable New Zealand carabids are as indicators. Given the low dispersal ability of New Zealand carabids they are thought to be particularly susceptible to habitat fragmentation compared to conspecifics in the northern hemisphere. This may make them more susceptible to mammal induced disappearances, with smaller isolated populations less likely to recover from mammal predation (Cartellieri \& Lövei, 2003; Lövei \& Cartellieri, 2000).

New Zealand carabids are mostly flightless and large-bodied which likely increases their vulnerability to mammal predation. There are indications that New Zealand carabids display lower levels of fecundity and egg laying capacity relative to carabids elsewhere. For instance the endemic Mecodema oconnori has been found with as few as 1.6 eggs per female, but this appears to vary substantially between species with other species such as Megadromus capito producing an average of 105 eggs (Hutchison, 2001). Lower fecundity likely leaves them less able to recover from periods of intense mammal predation but this may be offset somewhat by the ability of native carabids to breed all year round (Hutchison, 2007).

Carabidae in other regions of the world are known to exhibit several mechanisms to escape predation, most notably the use of chemical compounds such as formic acid produced in the pygidial glands (Lovei \& Sunderland, 1996). It is not known to what extent most New Zealand carabids use such defences. Due to the universal presence of these glands in carabids, it is likely that some species use them for this purpose. It is likely that the larval and egg stages of Carabidae life cycles are when they are the most vulnerable as larvae are less mobile, have less chitinous bodies and have few or poorly-developed anti-predator defences (Blackwell, 2000). This may also be when they are most vulnerable to mouse predation as they are likely within 
the preferred prey size of mice (Ruscoe, 2001), although there was no discernible effect of mouse predation on carabid size detected in this study. The effect of mammals on beetle larvae was not assessed in this study but is likely a significant element of mammal predation of beetles.

Whilst most carabids are thought to mature within one year and reproduce only once, some species have been recorded living for multiple seasons and producing several clutches of eggs. Carabids in the tribe Pterostichina, which includes the genera Megadromus, Holcaspis and Plocamostethus recoded in this study, are thought to be able to live for more than one season and reproduce multiple times. In addition, Plocamostethus planiusculus is known to exhibit egg guarding behaviour suggesting that larval stages of beetle development are the most vulnerable, although the exact threat that egg guarding is supposed to mitigate against, such as egg parasitism, mould or predation, is not known (Cartellieri \& Lövei, 2003; Lovei \& Sunderland, 1996).

Although species within the same family can exhibit similar behaviours, morphology and susceptibility to threats, it is also likely that beetle species do not all respond in the same way to mammal predation, even within the same family. Very little is known about the individual life histories of most New Zealand beetle species and it is therefore very difficult to establish which aspects of their behaviour or morphology are likely to make them susceptible to mammal predation (Hutchison, 2007; Lovei \& Sunderland, 1996). It is striking to notice the high conditional $\mathrm{R}^{2}$ value recorded for Scarabaeidae across all models. Scarabaeidae was the most homogenous taxonomic group examined with $>99 \%$ of individuals belonging to be the small (4-5mm) native dung beetle genus Saphobius. The random effects for both the LMER and GLMM models were "Site nested within Forest" so it would be expected that the less diverse and more homogenous beetle families would report higher conditional $\mathrm{R}^{2}$ values as abundance or size differences would change more uniformly in response to environmental conditions at each Site or Forest. This is what was broadly observed with, Scarabaeidae typically having the highest conditional $\mathrm{R}^{2}$ value followed by Carabaeidae (15 morphospecies), Staphylinidae (9 morphospecies) and other beetles (73 morphospecies). Higher conditional $\mathrm{R}^{2}$ values may also represent greater gregariousness amongst individuals within these groupings and it was noticeable that individuals in the genus Saphobius (Scarabaeidae) and the Carabids Ctenognathus bidens and Ctenognathus adamsi were typically highly abundant in a few pitfalls. The similar Ctenognathus novazelandiae is known to be highly gregarious (Philip \& Burgess, 2008). Although grouping beetles by family reduces the time and effort needed to sort 
and process beetles and increases sample sizes the differences between the marginal and conditional $\mathrm{R}^{2}$ values in different family groups suggest that it may obscure the importance of species identity in determining the response of beetles to introduced mammals.

\subsubsection{Conclusions}

The most consistent and robust model predictions for the overall impact of mammals on beetle communities was that higher tracking rates of both rats and mice were predicted to significantly reduce the catch rates of beetles caught in pitfall traps. This was true particularly for Carabidae and Scrabaeidae which declined in response to rats and mice, but significant results were also recorded for Staphylinidae and other beetles which declined in response to rats. The effect of rats and mice on overall beetle size was far less obvious and few firm conclusions can be drawn as to the general effect of rats and mice on beetle size other than to note that the largest group in terms of average size (Carabidae), saw declines in catch associated with both rats and mice.

The model predictions for the effect of hedgehog tracking on beetle size and abundance were also striking with some large (>100\%) increases in Carabidae and Scarabaeidae catch predicted to occur in association with an increased hedgehog index. It is possible that much of this relationship can be explained broader environmental factors rather than the top down regulation of invertebrate communities by hedgehogs. The most likely hypothesis is that increases in hedgehog index in association with high beetle catch reflects the greater hedgehog due to increased invertebrate abundance however further research is needed to understand this relationship.

The importance of considering a range of environmental factors and ensuring a sufficiently long study period was also emphasised by the results of this study. Large fluctuations in the catch rates of beetles were detected over time and space, and there was significant variability in the size and catch of beetles. Earlier analysis of pitfall trap specimens based on a three year time series failed to find significant relationships between mammal abundance and beetle size or catch (Vergara, 2018). However, with a sufficiently long sample period ( $>5$ years) and larger sample sizes, statistically significant results start to emerge. 


\section{Wètā}

\subsection{Results III - Ground dwelling wētā}

\subsubsection{Body size}

Two significant results were found for the impact of increased mammal tracking on the average size of pitfall trapped wētā (Table 3.1). A rat index of one was estimated to reduce the average size of pitfall trapped cave wētā by $2.5 \mathrm{~mm}(\mathrm{P}=0.003)$ over a rat index of zero, the conditional $\mathrm{R}^{2}$ value for this model was 0.17 . The size of this effect appeared greater for individuals caught in November (Figure 3.1B) whilst there was significant variability in overall cave wètā size. No significant results were found for any of the ground wētā groupings and rats. Male ground wêtā were estimated to be $2.2 \mathrm{~mm}$ larger in the presence of abundant mice $(\mathrm{P}=0.004)$ with a conditional $\mathrm{R}^{2}$ of 0.16 . This result was only apparent in individuals trapped in February (Figure 3.2B). Nearly significant results were found for juvenile ground wētā which were estimated to be $1.4 \mathrm{~mm}$ larger $(\mathrm{P}=0.040)$. Hedgehogs tracking did not show any significant associations with mean wētā size in pitfall traps.

In the time delay model (T-1) there were several significant results found for the effect of mice on wētā size. Cave wêtā were estimated to be $4.4 \mathrm{~mm}$ larger in the presence of abundant mice $(\mathrm{P}=0.003)$ (Figure 3.3) whilst ground wêtā were estimated to be $5.2 \mathrm{~mm}$ larger $(\mathrm{P}=0.007)$ (Figure 3.4). Male ground wêtā seemed to show the strongest relationship with a highly significant $3.4 \mathrm{~mm}$ increase in size predicted $(\mathrm{P}<0.001)$ (Figure 3.5), as with the $\mathrm{T}-0$ model this result was only obvious for individuals trapped in February (Figure 3.5B). No other significant relationships were found between mammal tracking in the previous season and wētā size although increases in the size of juvenile ground wētā and ground wêtā overall in relation to hedgehog index approached significance. The $\mathrm{R}^{2}$ vales were greater in the $\mathrm{T}-1$ model for all wêtā groupings besides juvenile ground wêtā. The conditional $\mathrm{R}^{2}$ values for cave wêtā, male and female ground wêtā increased from $0.17,0.16$ and 0.21 to $0.22,0.29$ and 0.24 respectively. For ground wētā overall this increased from 0.09 to 0.11 and for juvenile ground wētā this declined from 0.17 to 0.15 . 


\subsubsection{Pitfall catch}

Results for wêtā catch and mammal tracking are shown in Table 3.2. Male and female adult ground wētā catch was significantly reduced by the impact of increased rat tracking (Figure 3.6). Male ground wētā were estimated to be $43.5 \%$ less abundant in areas with a rat index of one compared with an index of zero $(\mathrm{P}=0.004)$ whilst female ground wētā were estimated to be $57.5 \%$ less abundant $(\mathrm{P}<0.001)$. This translated into a $44.3 \%$ predicted decline for ground wētā overall when juvenile ground wētā were included $(\mathrm{P}<0.001)$. Female ground wētā catch was estimated to be $492.6 \%$ higher in the presence of abundant hedgehogs $(\mathrm{P}<0.001)$ and ground wētā overall 236.3\% higher $(\mathrm{P}<0.001)$ (Figure 3.8). An increase in catch of female ground wētā and wētā overall with increased mouse abundance (Figure 3.7) approached significance as did the relationship between juvenile ground wêtā and increased hedgehog tracking.

In the T-1 model, decreased cave wêtā catch became significantly correlated with increased rat index in the previous season with an estimated $42.7 \%$ decrease in catch $(\mathrm{P}=0.003)$ for a rat tracking rate of one relative to a tracking rate of zero. As with the T-0 model wêtā catch was estimated to decline in response to high rat index in the previous season with the model predicting a $48.9 \%$ decline in catch $(\mathrm{P}<0.001)$. Female ground wētā showed a strong decline in catch estimated to be worth $62.2 \%(\mathrm{P}<0.001)$ (Figure 3.9). Decline in catch for male $(\mathrm{P}=0.012)$ and juvenile wētā $(\mathrm{P}=0.020)$ approached significance. Neither mouse nor hedgehog tracking in the previous season appeared to significantly impact on ground wêtā catch (Figure $3.10 \& 3.11)$. $\mathrm{R}^{2}$ values were broadly comparable across both models with the conditional $\mathrm{R}^{2}$ value for cave wētā catch increasing from 0.17 to 0.26 and decreasing from 0.28 to 0.22 for ground wētā. Conditional $\mathrm{R}^{2}$ value for male, female and juvenile ground wētā declined from $0.09,0.03$ and 0.04 to 0.070 .02 . and 0.03 respectively, in the T-1 model. 
Table 3.1 LMER model and ANOVA type 3 estimates ( $\operatorname{Pr}(>\mathrm{Chisq})$ ) for the effect on ground dwelling wētà size of an increase in mammal tracking from 0 to 1 within the current and previous (T1) seasons, while controlling for the effect of squid bait (effects not shown). Random effects were site nested within forest. Each row is a model with a different wēta group as the response variable and the mammal index of each species as additive predictor variables. ${ }^{*} \mathrm{P}<0.05,{ }^{*}=\mathrm{P}<0.001,{ }^{*} * *=\mathrm{P}<0.001$. Arrows indicate the direction of results deemed statistically significant at the $\mathrm{P}<0.01$ level.

\begin{tabular}{|c|c|c|c|c|c|c|c|c|c|c|c|c|c|c|c|}
\hline \multirow[t]{2}{*}{ Size } & \multicolumn{4}{|l|}{ Rats } & \multicolumn{4}{|l|}{ Mice } & \multicolumn{7}{|c|}{ Hedgehog } \\
\hline & $\beta(\mathbf{m m})$ & SE & t-value & $\operatorname{Pr}(>$ Chisq $)$ & $\beta(\mathbf{m m})$ & $\mathbf{S E}$ & t-value & $\operatorname{Pr}(>$ Chisq $)$ & $\beta(\mathbf{m m})$ & $\mathbf{S E}$ & t-value & $\operatorname{Pr}(>$ Chisq $)$ & Marginal $\mathbf{R}^{2}$ & Conditional $\mathbf{R}^{2}$ & Sample size \\
\hline Cave wētā & $\downarrow-2.5$ & 0.9 & -2.9 & $0.003 * *$ & 0.9 & 1.4 & 0.6 & 0.532 & 2.4 & 2.0 & 1.2 & 0.247 & 0.08 & 0.17 & 515 \\
\hline Ground wētā & 0.0 & 1.1 & 0.0 & 0.998 & 1.6 & 1.5 & 1.1 & 0.284 & 3.6 & 1.9 & 1.9 & 0.056 & 0.02 & 0.09 & 1207 \\
\hline Male gw & 0.5 & 0.6 & 0.9 & 0.390 & $\uparrow 2.2$ & 0.7 & 2.9 & $0.004^{* *}$ & 0.5 & 1.2 & 0.4 & 0.666 & 0.04 & 0.16 & 442 \\
\hline Female gw & 2.3 & 0.9 & 2.5 & 0.013 & 0.2 & 1.3 & 0.1 & 0.900 & -0.1 & 1.4 & -0.0 & 0.964 & 0.03 & 0.21 & 293 \\
\hline Juvenile gw & 0.3 & 0.9 & 0.3 & 0.775 & -2.9 & 1.4 & -2.1 & $0.040^{*}$ & 1.8 & 1.7 & 1.0 & 0.296 & 0.06 & 0.17 & 460 \\
\hline \multirow[t]{2}{*}{ Size T-1 } & \multicolumn{4}{|c|}{ Rats (T-1) } & \multicolumn{4}{|c|}{ Mice (T-1) } & \multicolumn{7}{|c|}{ Hedgehog (T-1) } \\
\hline & $\beta(\mathbf{m m})$ & SE & t-value & $\operatorname{Pr}(>$ Chisq) & $\beta(\mathbf{m m})$ & SE & t-value & $\operatorname{Pr}(>$ Chisq) & $\beta(\mathbf{m m})$ & SE & t-value & $\operatorname{Pr}(>$ Chisq $)$ & Marginal $\mathbf{R}^{2}$ & Conditional $\mathbf{R}^{2}$ & Sample size \\
\hline Cave wētā & -1.0 & 1.0 & -1.0 & 0.306 & $\uparrow 4.4$ & 1.5 & 2.9 & $0.003 * *$ & 2.1 & 2.1 & 0.9 & 0.331 & 0.11 & 0.22 & 408 \\
\hline Ground wētā & 1.0 & 1.3 & 0.7 & 0.463 & $\uparrow 5.2$ & 1.9 & 2.7 & $0.007 * *$ & 4.6 & 2.3 & 2.0 & $0.048 *$ & 0.04 & 0.11 & 1036 \\
\hline Male gw & 0.2 & 0.8 & 0.3 & 0.752 & $\uparrow 3.4$ & 1.0 & 3.5 & $<0.001 * * *$ & 0.1 & 1.4 & 0.0 & 0.963 & 0.06 & 0.29 & 373 \\
\hline Female gw & 2.4 & 1.4 & 1.6 & 0.099 & 1.1 & 1.8 & 0.6 & 0.551 & 1.6 & 2.2 & 0.7 & 0.472 & 0.03 & 0.24 & 234 \\
\hline Juvenile gw & 1.8 & 1.0 & 1.8 & 0.068 & 2.0 & 1.7 & 1.2 & 0.236 & 3.7 & 1.8 & 2.0 & $0.044 *$ & 0.07 & 0.15 & 429 \\
\hline
\end{tabular}


Table 3.2 GLMM model estimates for the effect on ground dwelling wètā catch of an increase in mammal index from 0 to 1 in the current and previous (T-1) season, while controlling for season and squid bait. Random effects were site nested within forest. Sample size was 1819 pitfalls, number of individual beetles caught is the same as for corresponding LMER models shown in Table

3.1. Each row is a model with a different wêtā group as the response variable and the mammal index of each species as additive predictor variables. $* \mathrm{P}<0.05, * *=\mathrm{P}<0.001, * * *=\mathrm{P}<0.001$. Arrows indicate the direction of results deemed statistically significant at the $\mathrm{P}<0.01$ level.

\begin{tabular}{|c|c|c|c|c|c|c|c|c|c|c|c|c|c|c|c|c|c|}
\hline \multirow[t]{2}{*}{ Abundance } & \multicolumn{5}{|l|}{ Rats } & \multicolumn{5}{|l|}{ Mice } & \multicolumn{7}{|c|}{ Hedgehog } \\
\hline & $\beta$ & $\begin{array}{l}\text { Estimate } \\
(\%)\end{array}$ & SE & t-value & $\operatorname{Pr}(>$ Chisq $)$ & $\beta$ & $\begin{array}{l}\text { Estimate } \\
(\%)\end{array}$ & SE & t-value & $\operatorname{Pr}(>$ Chisq) & $\beta$ & $\begin{array}{l}\text { Estimate } \\
(\%)\end{array}$ & $\mathbf{S E}$ & t-value & $\operatorname{Pr}(>$ Chisq $)$ & $\begin{array}{l}\text { Marginal } \\
\mathbf{R}^{2}\end{array}$ & $\begin{array}{l}\text { Conditional } \\
\mathbf{R}^{2}\end{array}$ \\
\hline Cave wêtā & -0.34 & -28.8 & 0.16 & -2.14 & $0.033^{*}$ & 0.34 & 40.9 & 0.25 & 1.36 & 0.169 & 0.09 & 9.3 & 0.38 & 0.24 & 0.814 & 0.08 & 0.17 \\
\hline Ground wētà & $\downarrow-0.59$ & -44.3 & 0.14 & -4.20 & $<0.001 * * *$ & 0.48 & 62.4 & 0.19 & 2.55 & $0.011 *$ & $\uparrow 1.21$ & 236.3 & 0.25 & 4.89 & $<0.001 * * *$ & 0.20 & 0.28 \\
\hline Male gw & $\downarrow-0.57$ & -43.3 & 0.20 & -2.85 & $0.004 * *$ & 0.14 & 14.7 & 0.28 & 0.49 & 0.623 & 0.65 & 91.0 & 0.39 & 1.70 & 0.095 & 0.08 & 0.09 \\
\hline Female gw & $\downarrow-0.86$ & -57.5 & 0.24 & -3.57 & $<0.001 * * *$ & 0.74 & 110.5 & 0.33 & 2.2 & $0.025^{*}$ & $\uparrow 1.78$ & 492.6 & 0.40 & 4.50 & $<0.001 * * *$ & 0.03 & 0.03 \\
\hline Juvenile gw & -0.46 & -37.0 & 0.19 & -2.46 & $0.014 *$ & 0.31 & 36.1 & 0.28 & 1.1 & 0.271 & 0.74 & 110.3 & 0.36 & 2.04 & $0.041 *$ & 0.03 & 0.04 \\
\hline \multirow{2}{*}{$\begin{array}{l}\text { Abundance } \\
\text { T-1 }\end{array}$} & \multicolumn{5}{|c|}{ Rats (T-1) } & \multicolumn{5}{|c|}{ Mice (T-1) } & \multicolumn{7}{|c|}{ Hedgehog (T-1) } \\
\hline & $\beta$ & $\begin{array}{l}\text { Estimate } \\
(\%)\end{array}$ & $\mathbf{S E}$ & t-value & $\operatorname{Pr}(>$ Chisq $)$ & $\beta$ & $\begin{array}{l}\text { Estimate } \\
(\%)\end{array}$ & SE & t-value & $\operatorname{Pr}(>$ Chisq) & $\beta$ & $\begin{array}{l}\text { Estimate } \\
(\%)\end{array}$ & $\mathbf{S E}$ & t-value & $\operatorname{Pr}(>$ Chisq $)$ & $\begin{array}{l}\text { Marginal } \\
\mathbf{R}^{2}\end{array}$ & $\begin{array}{l}\text { Conditional } \\
\mathbf{R}^{\mathbf{2}}\end{array}$ \\
\hline Cave wētā & $\downarrow-0.56$ & -42.7 & 0.18 & -3.02 & $0.003 * *$ & 0.22 & 24.3 & 0.29 & 0.76 & 0.448 & -0.64 & -47.4 & 0.42 & -1.52 & 0.128 & 0.11 & 0.26 \\
\hline Ground wētā & $\downarrow-0.67$ & -48.9 & 0.17 & -3.90 & $<0.001 * * *$ & 0.06 & 6.7 & 0.24 & 0.26 & 0.792 & -0.05 & -4.4 & 0.33 & -0.14 & 0.890 & 0.17 & 0.22 \\
\hline Male gw & -0.62 & -46.4 & 0.25 & -2.52 & $0.012 *$ & 0.35 & 41.8 & 0.32 & 1.08 & 0.282 & 0.1 & 12.6 & 0.47 & 0.25 & 0.800 & 0.06 & 0.07 \\
\hline Female gw & $\downarrow-0.97$ & -62.2 & 0.28 & -3.45 & $<0.001 * * *$ & 0.21 & 23.7 & 0.40 & 0.54 & 0.592 & 0.06 & 5.9 & 0.53 & 0.11 & 0.914 & 0.02 & 0.02 \\
\hline Juvenile gw & -0.51 & -40.2 & 0.22 & -2.32 & $0.020^{*}$ & -0.50 & -39.2 & 0.39 & -1.29 & 0.198 & -0.44 & -35.8 & 0.45 & -0.98 & 0.326 & 0.03 & 0.03 \\
\hline
\end{tabular}



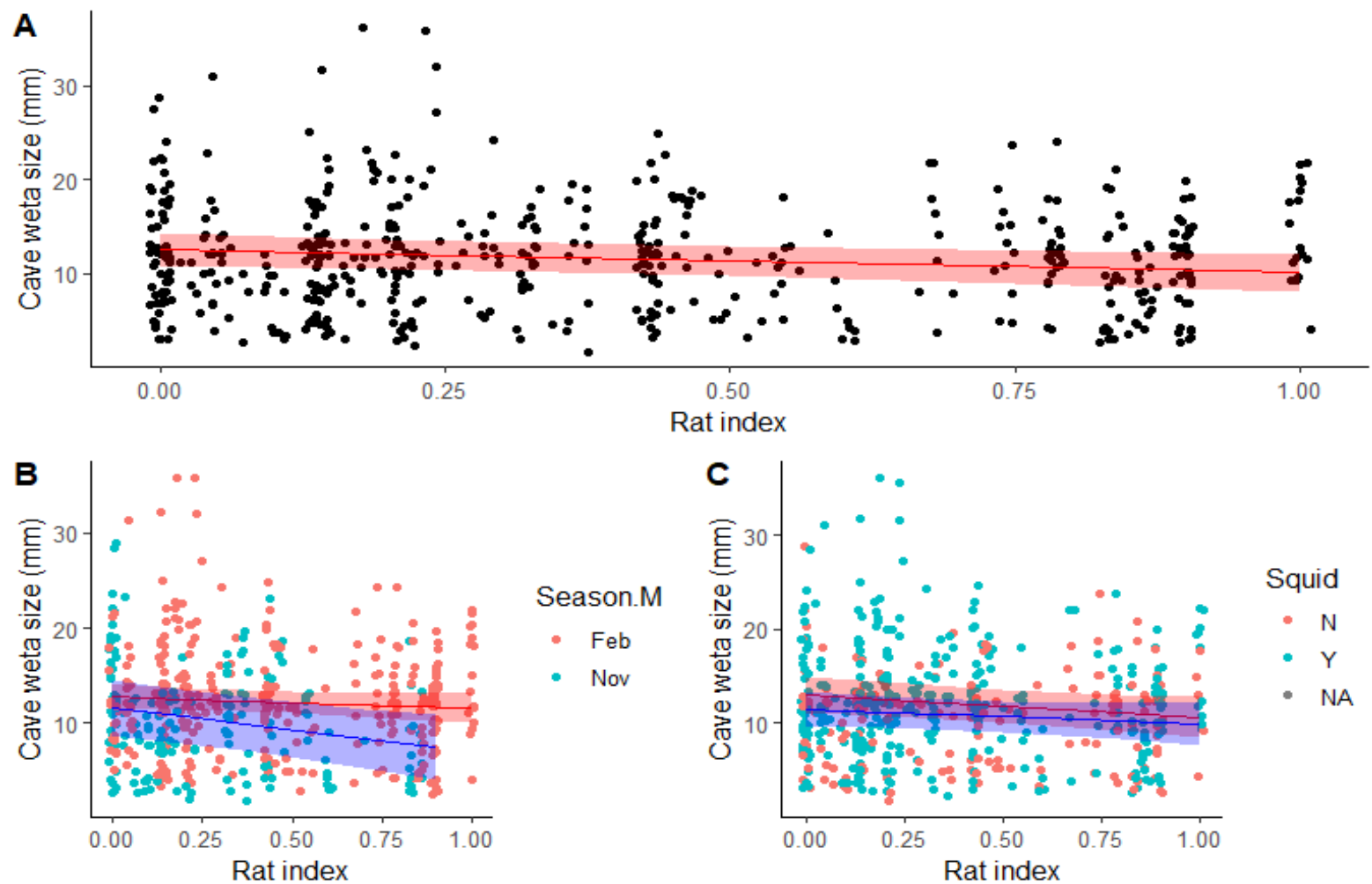

Figure 3.1 Cave wētā size (mm) and rat index (A) by season (B) and squid baiting (C), each point represents an individual wētā, points have been jittered to allow for easier visualisation of data clusters.
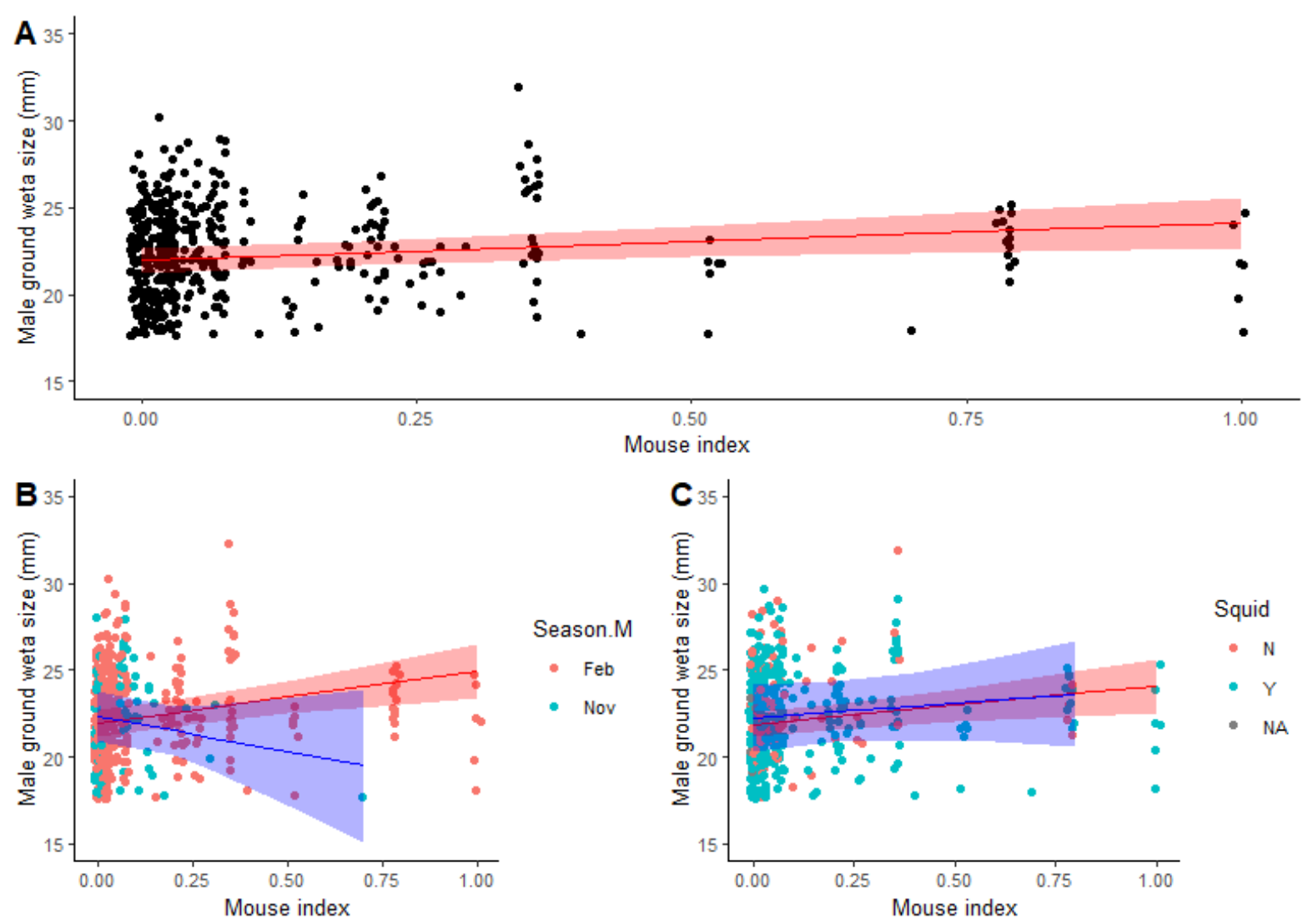

Figure 3.2 Male ground wētā size (mm) and mouse index (A) by season (B) and squid baiting (C), each point represents an individual wētā, points have been jittered to allow for easier visualisation of data clusters. 

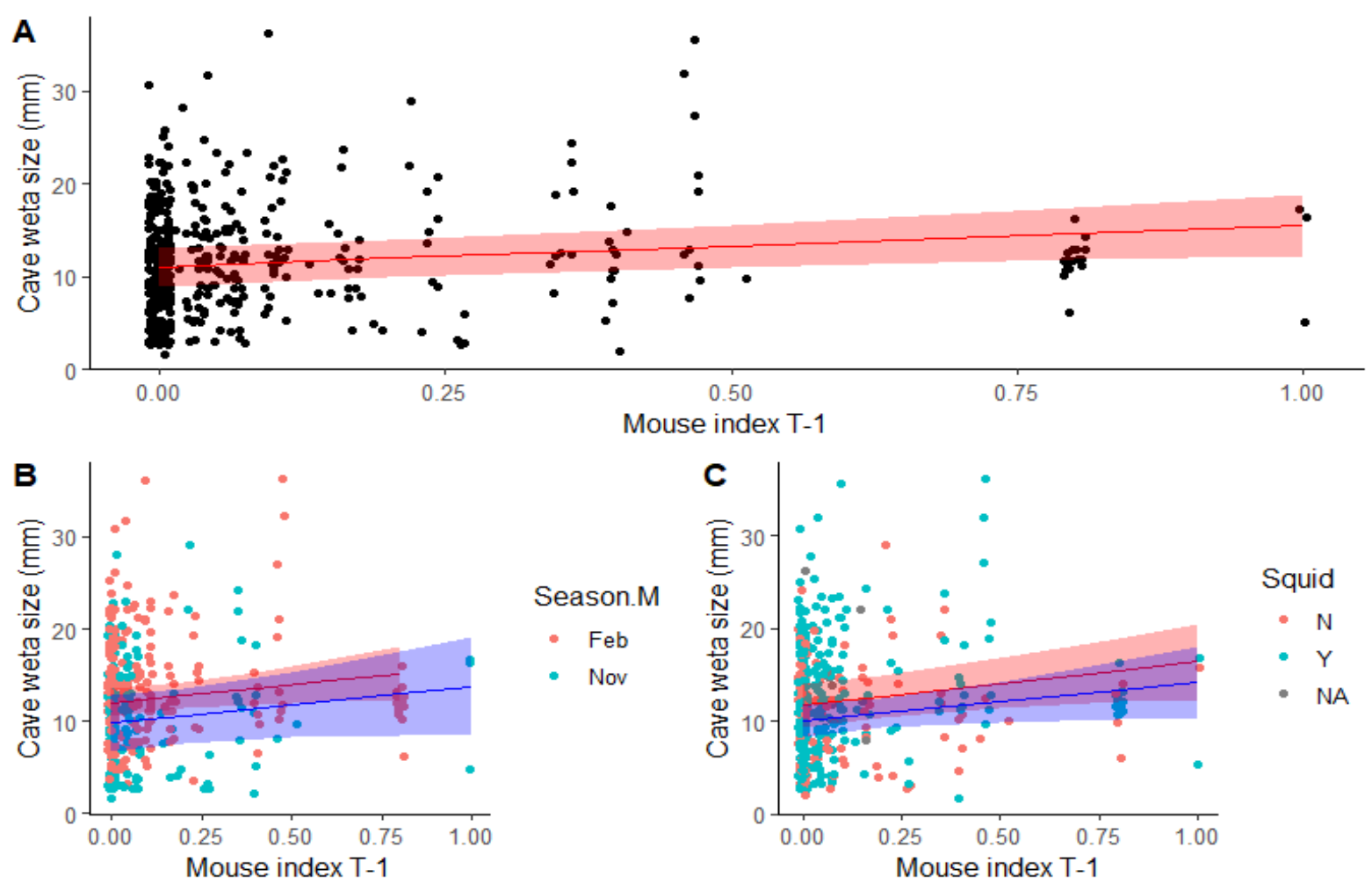

Figure 3.3 Cave wētā size and mouse index in the previous season (A) by season (B) and squid baiting (C), each point represents an individual wētā, points have been jittered to allow for easier visualisation of data clusters.
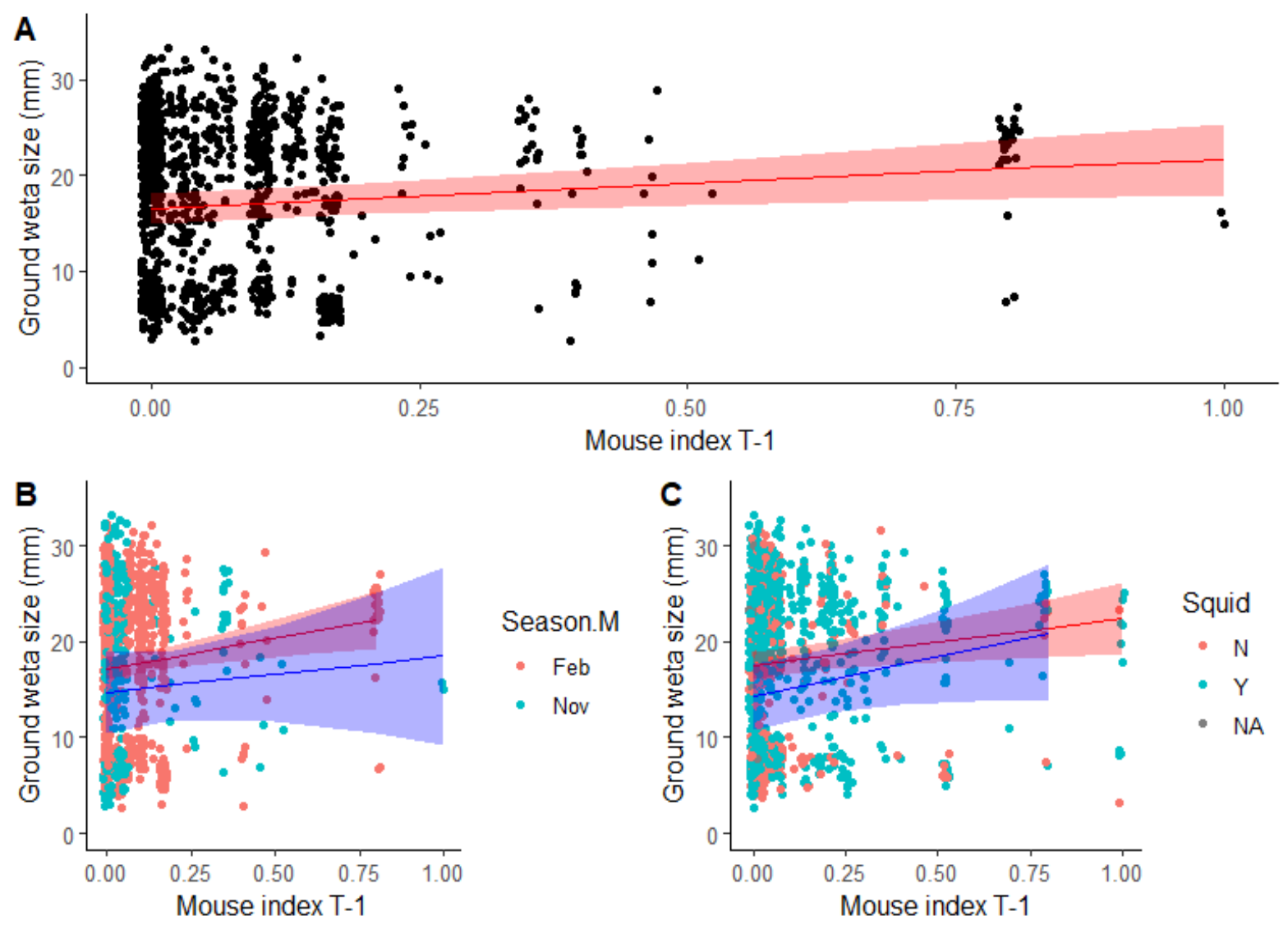

Figure 3.4 Cave wētā size (mm) and mouse index in the previous season (A) by season (B) and squid baiting (C), each point represents an individual wētā, points have been jittered to allow for easier visualisation of data clusters. 

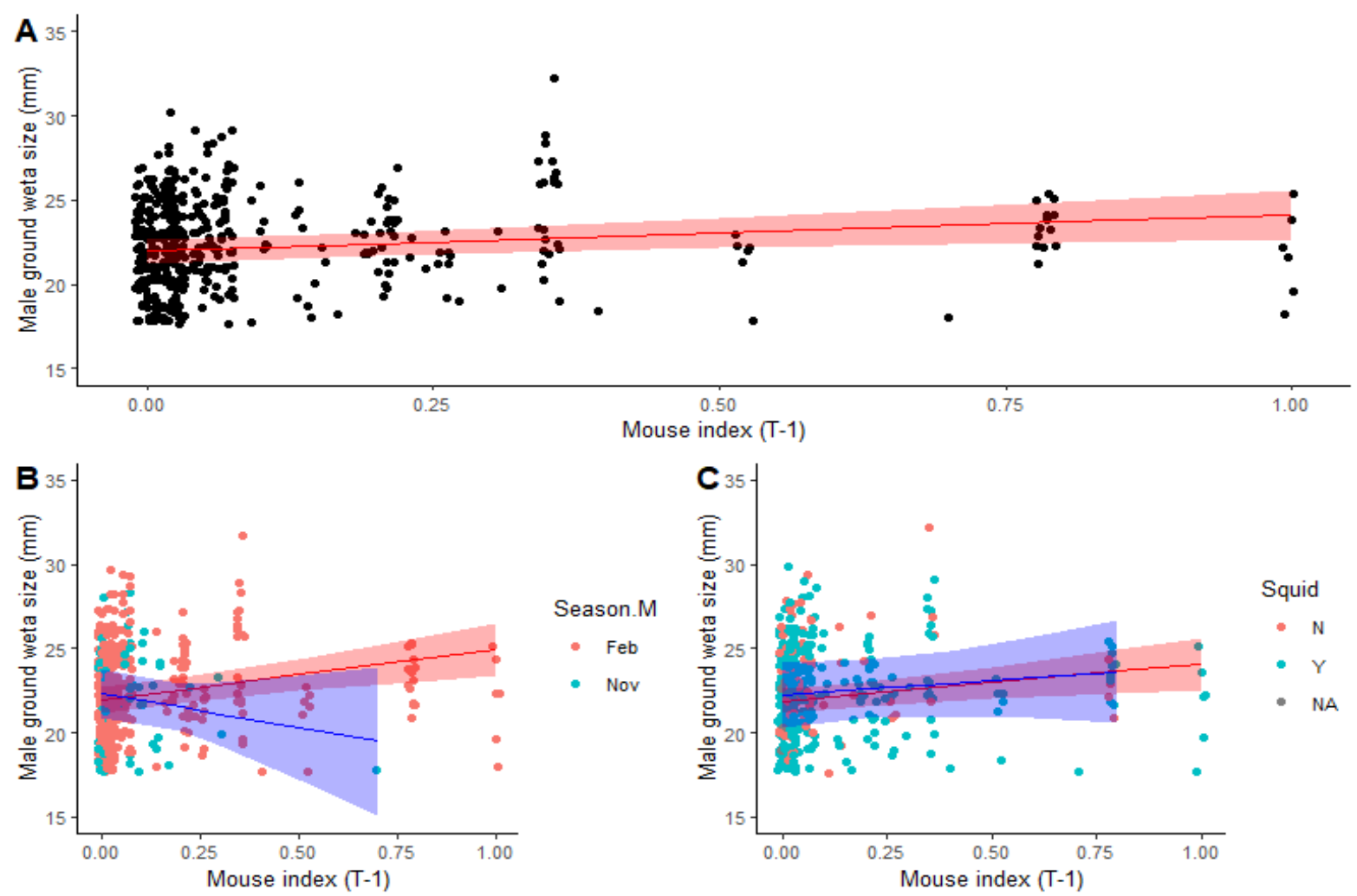

Figure 3.5 Male ground wētā size (mm) and mouse index in the previous season (A) by season (B) and squid baiting (C), each point represents an individual wētā, points have been jittered to allow for easier visualisation of data clusters.
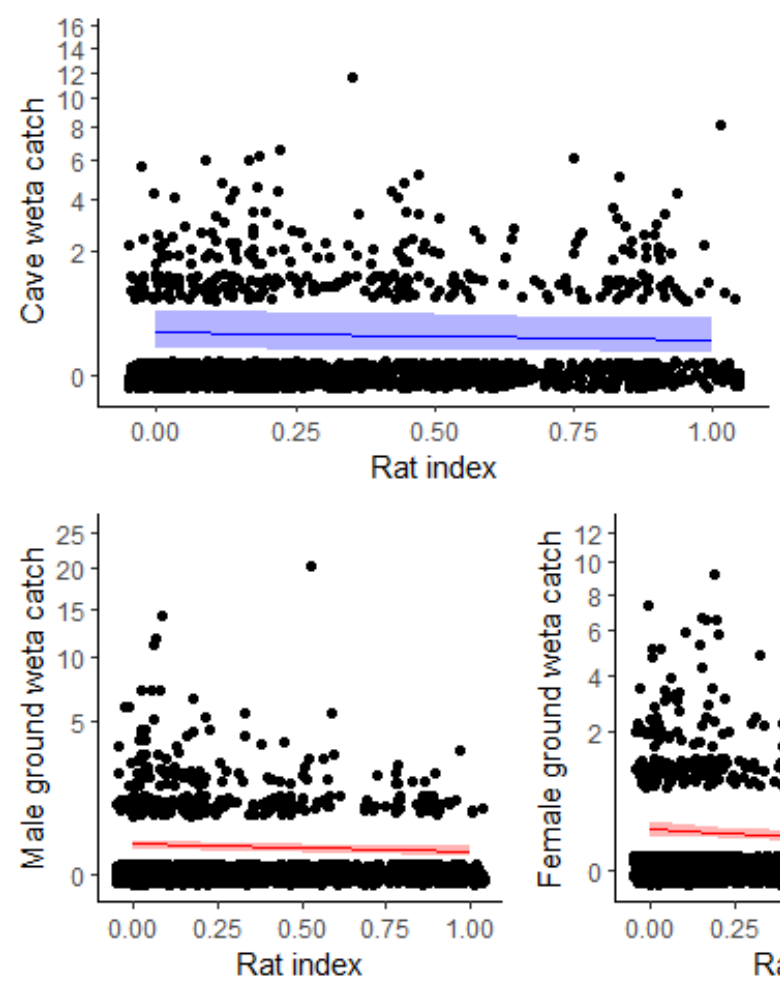

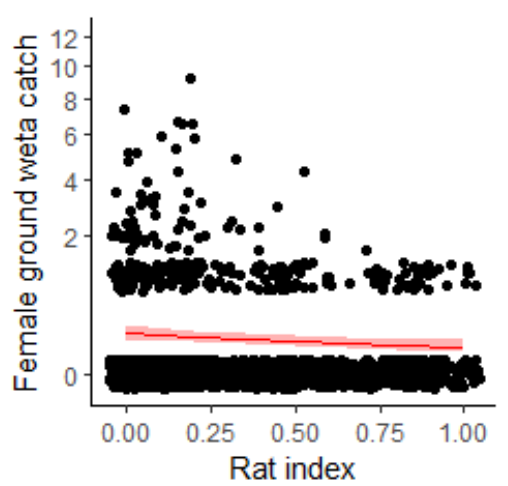

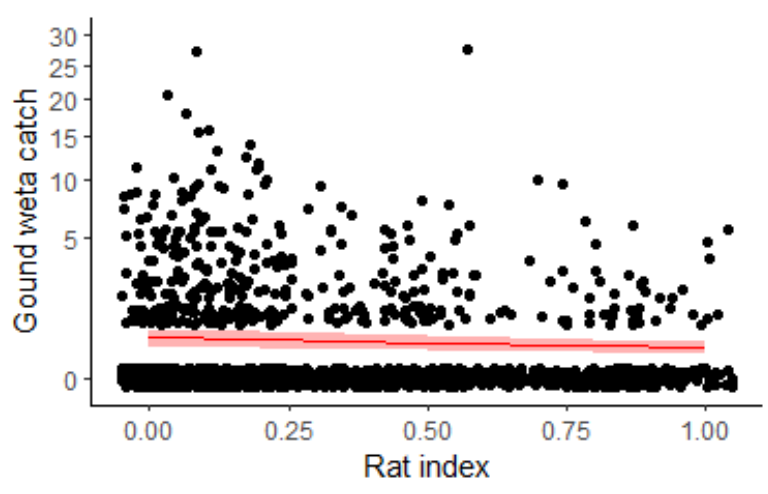

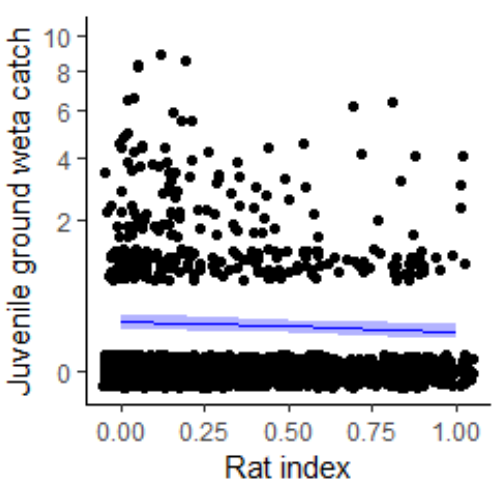

Figure 3.6 GLMM model estimates of the effect of an increase in rat index from 0 to 1 , on wētā pitfall catch by group including 95\% confidence intervals. Individual data points indicate the catch in an individual pitfall, points have been randomly jittered and square root transformed to allow for easier data visualisation, y axis values have been back transformed to raw pitfall catch values. Significant $(\mathrm{P}<0.01)$ model predictions are shown in red. 

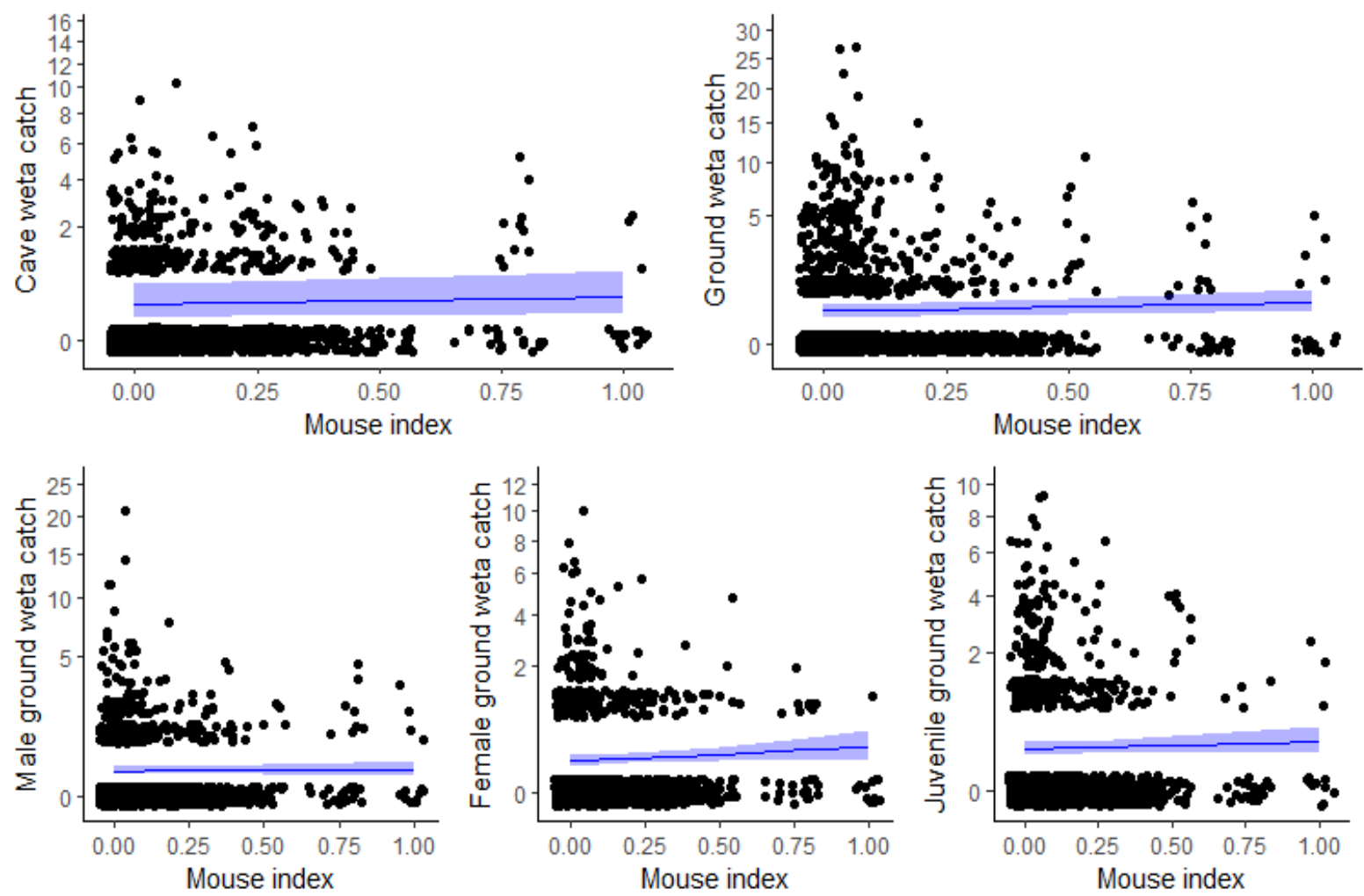

Figure 3.7 GLMM model estimates of the effect of an increase in mouse index from 0 to 1 , on wētā pitfall catch by group including 95\% confidence intervals. Individual data points indicate the catch in an individual pitfall, points have been randomly jittered and square root transformed to allow for easier data visualisation, y axis values have been back transformed to raw pitfall catch values. Significant $(\mathrm{P}<0.01)$ model predictions are shown in red.
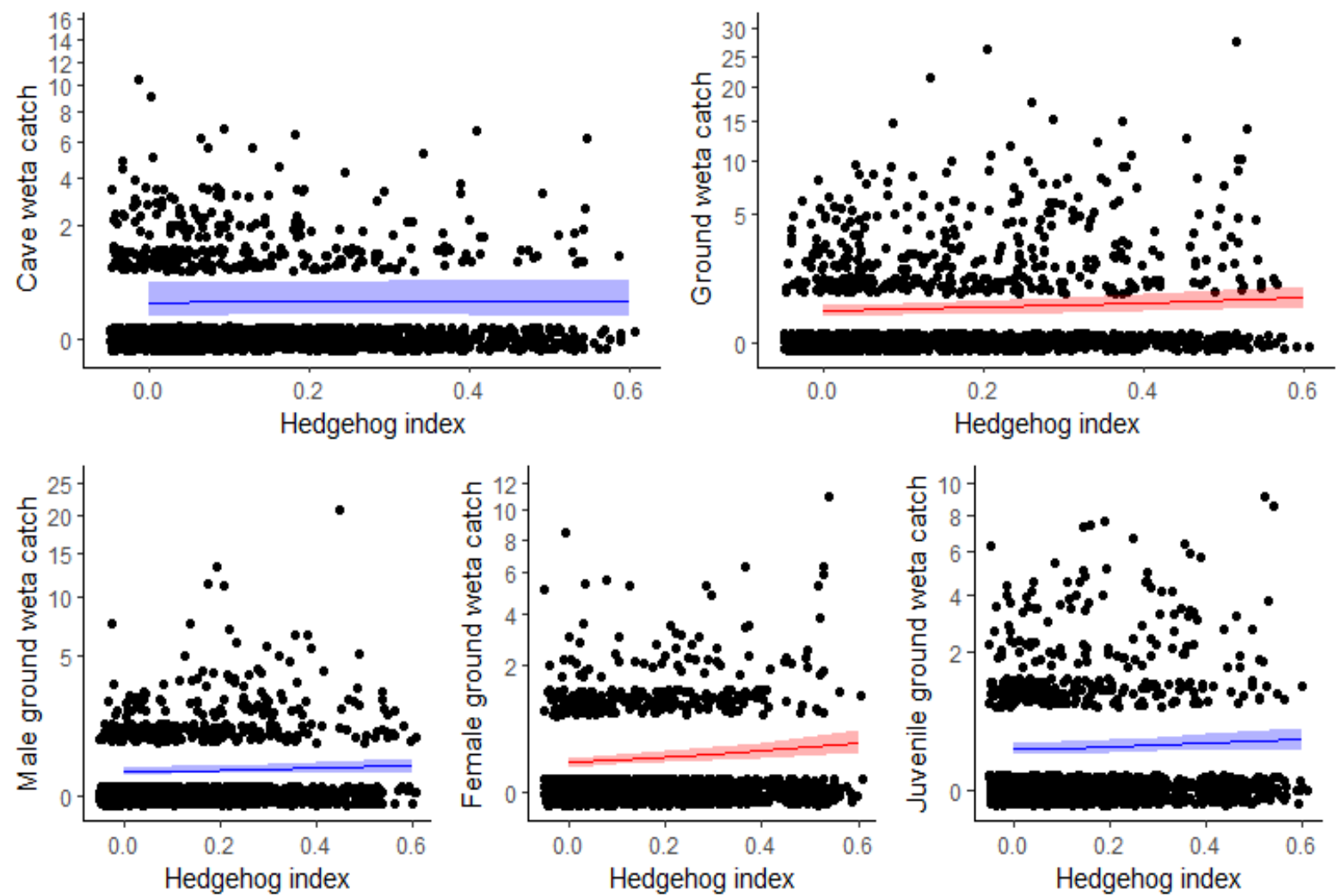

Figure 3.8 GLMM model estimates of the effect of an increase in hedgehog index from 0 to 1 , on wêtā pitfall catch by group including 95\% confidence intervals. Individual data points indicate the catch in an individual pitfall, points have been randomly jittered and square root transformed to allow for easier data visualisation, y axis values have been back transformed to raw pitfall catch values. Significant $(\mathrm{P}<0.01)$ model predictions are shown in red. 

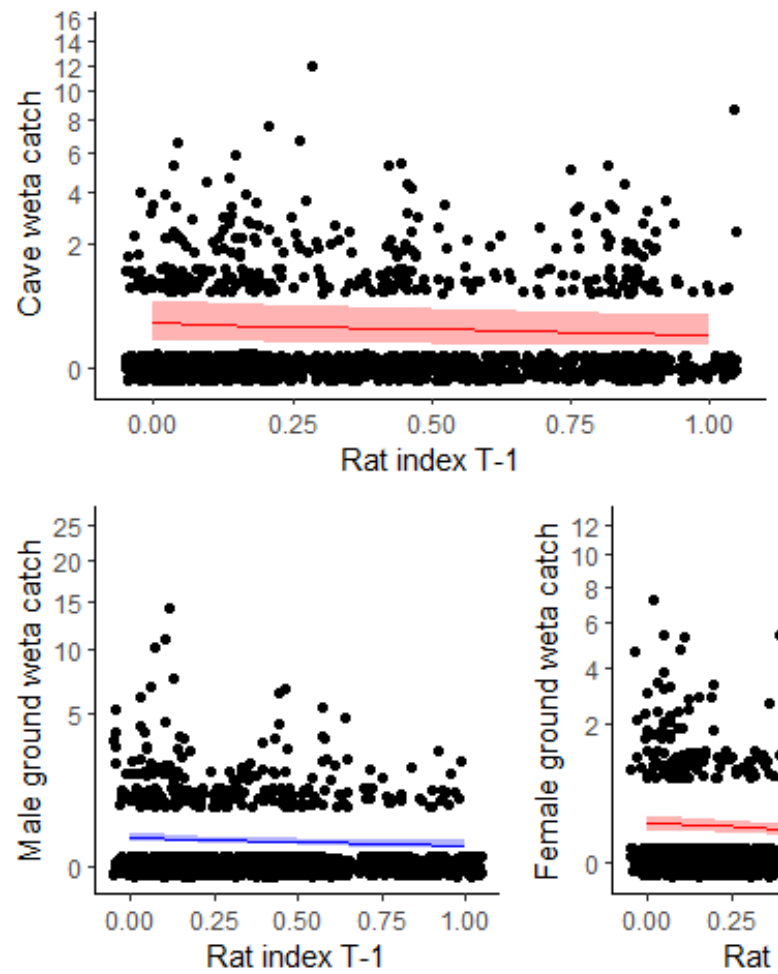

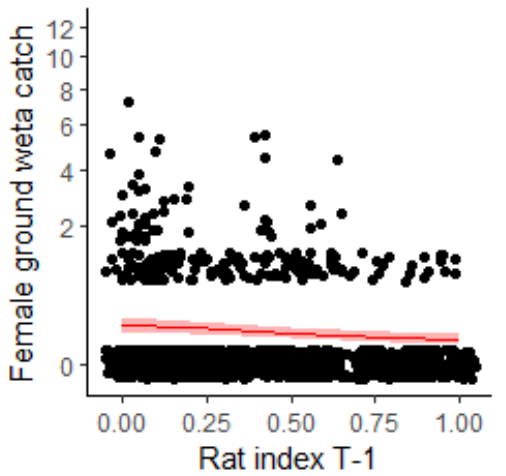

Rat index T-1
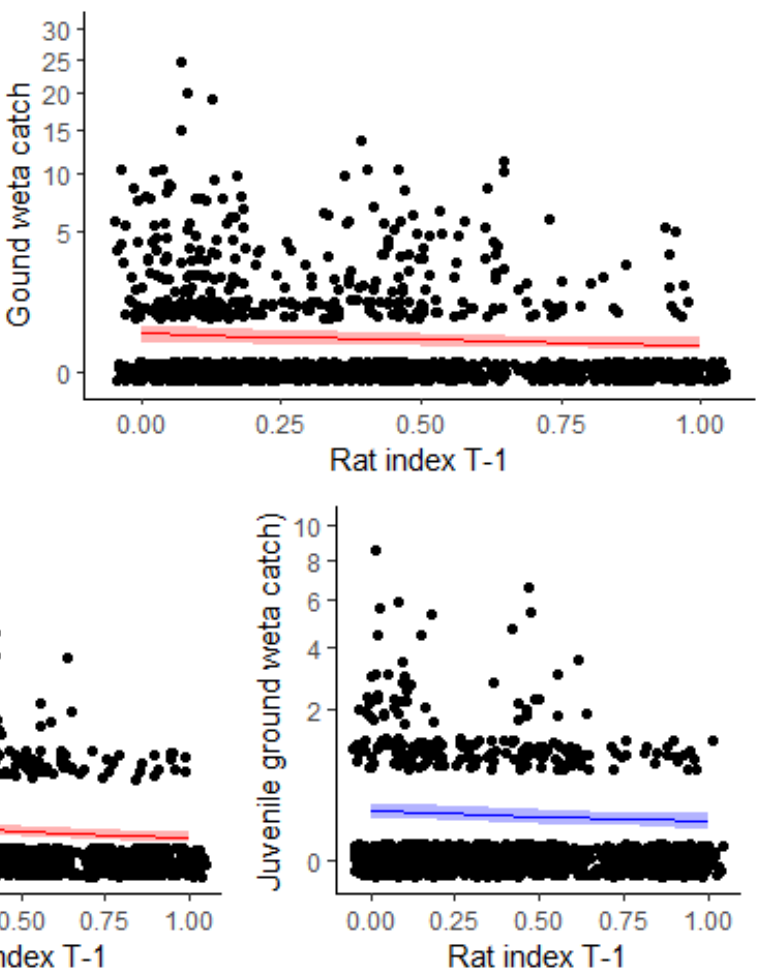

Figure 3.9 GLMM model estimates of the effect of an increase in rat index from 0 to 1 in the previous season, on wētā pitfall catch by group including $95 \%$ confidence intervals. Individual data points indicate the catch in an individual pitfall, points have been randomly jittered and square root transformed to allow for easier data visualisation, y axis values have been back transformed to raw pitfall catch values. Significant $(\mathrm{P}<0.01)$ model predictions are shown in red.
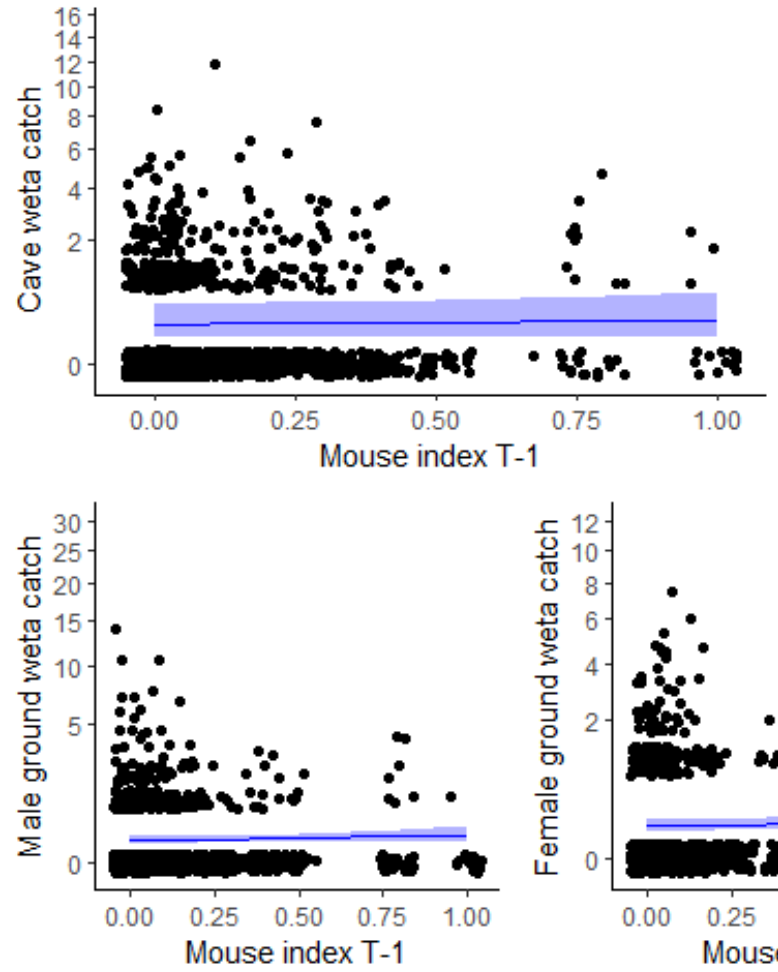

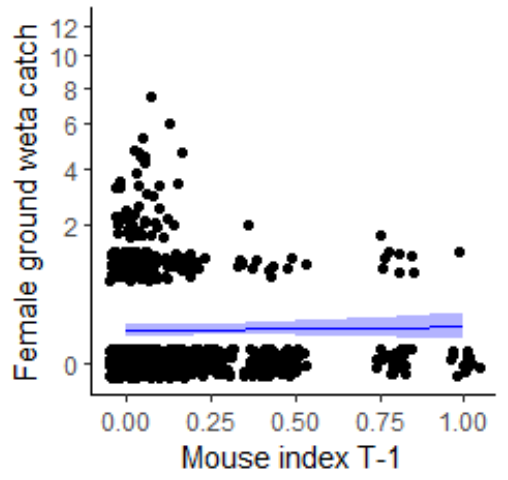

Figure 3.10 GLMM model estimates of the effect of an increase in mouse index from 0 to 1 in the previous season, on wētā pitfall catch by group including $95 \%$ confidence intervals. Individual data points indicate the catch in an individual pitfall, points have been randomly jittered and square root transformed to allow for easier data visualisation, y axis values have been back transformed to raw pitfall catch values. Significant $(\mathrm{P}<0.01)$ model predictions are shown in red. 

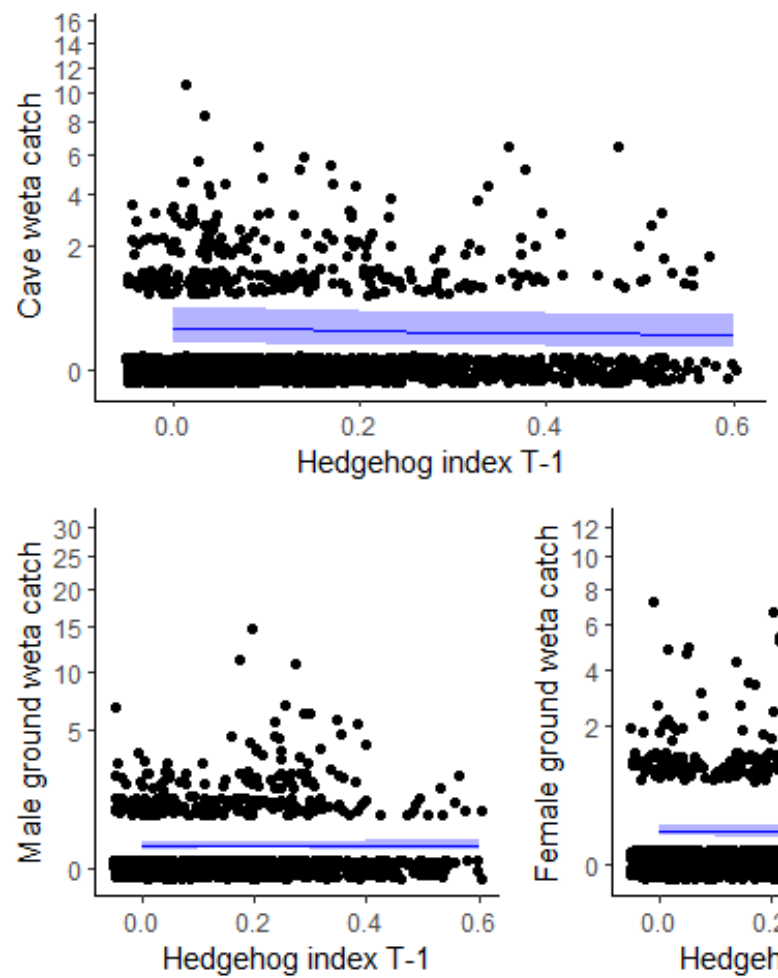
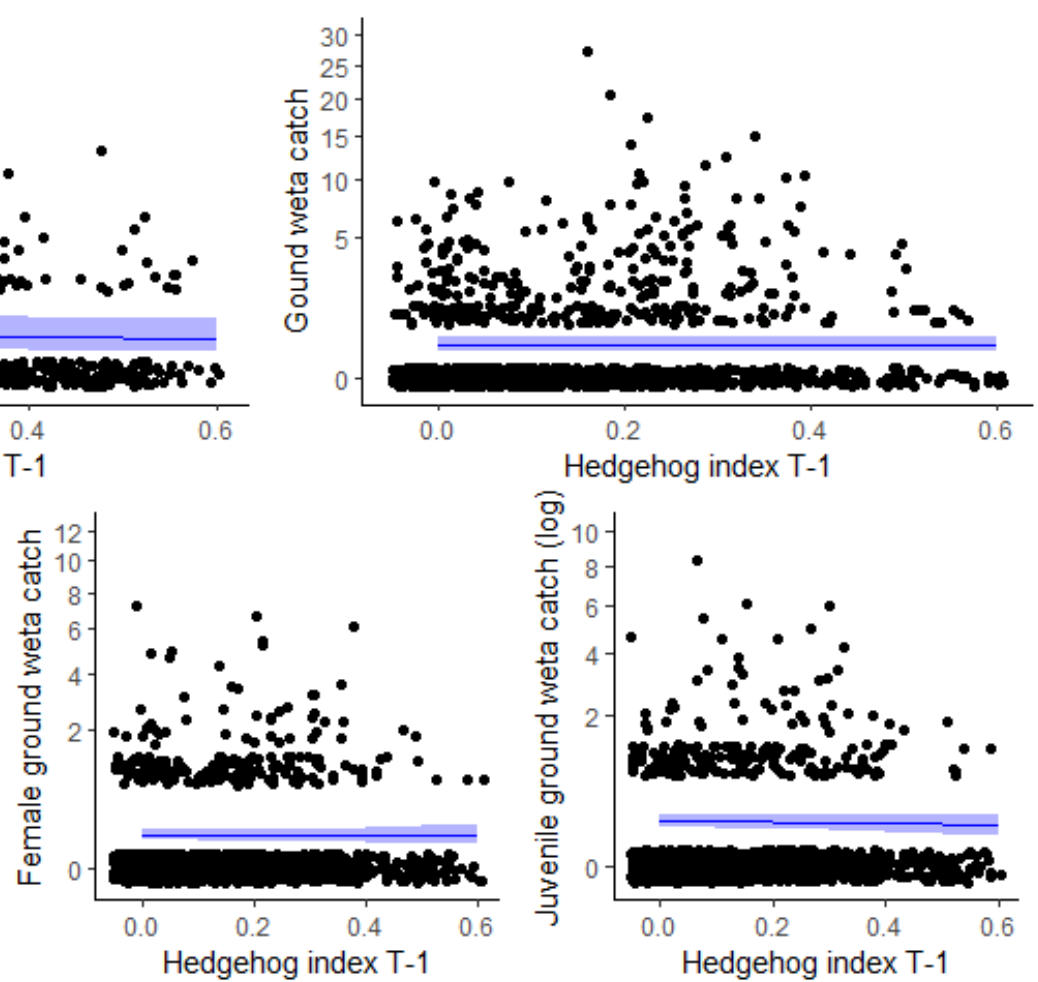

Figure 3.11 GLMM model estimates of the effect of an increase in hedgehog index from 0 to 1 in the previous season, on wētā pitfall catch by group including 95\% confidence intervals. Individual data points indicate the catch in an individual pitfall, points have been randomly jittered and square root transformed to allow for easier data visualisation, y axis values have been back transformed to raw pitfall catch values. Significant $(\mathrm{P}<0.01)$ model predictions are shown in red.

\subsection{Results IV - Cavity dwelling wètā}

\subsubsection{Body size}

No statistically significant $(\mathrm{P}<0.01)$ size differences were found for cavity dwelling wêtā apart from female tree wêtā (Table 3.3). Female tree wētā were estimated to be $5 \mathrm{~mm}$ larger in the presence of abundant mice compared with the absence of mice $(\mathrm{P}=0.007)$ (Figure 3.12). The conditional $\mathrm{R}^{2}$ for this prediction was 0.18 . Increases in the size of male tree wêtā $(\mathrm{P}=0.040)$ and tree wêtā overall $(\mathrm{P}=0.032)$ associated with an increase in mouse tracking but did not achieve significance. Cave wētā were estimated to be a $23.4 \mathrm{~mm}$ larger in the presence of abundant hedgehogs however this result also failed to achieve significance $(\mathrm{P}=0.043)$.

In the time delay (T-1) model there were no significant results for the effect of mammals on wêtā size. Conditional $\mathrm{R}^{2}$ values changed very little from the $\mathrm{T}-0$ model, falling from 0.18 and 0.09 to 0.16 and 0.08 for female tree wêtā and all tree wētā respectively whilst increasing from 0.06 to 0.08 for male tree wêtā and remaining at 0.09 for cave wêtā. These values indicate only a small portion of wētā size variation was accounted for in the models. 


\subsubsection{Wētā motel occupancy}

The number of tree wêtā recorded in wētā motels ranged between 0 and 8 individuals with a mean occupancy of 0.8 suggesting that most motels were empty. Statistically significant changes in cavity dwelling occupancy were found only for tree wêtā in response to increased mouse tracking. Tree wētā occupancy was predicted to fall 53.3\% in response to an abundance of mice compared with the absence of mice $(\mathrm{P}=0.004)$. This appeared to be most significant for female tree wētā which were predicted to decline by $68.6 \%(\mathrm{P}=0.003)$. Conditional $\mathrm{R}^{2}$ were low and all were $<0.14$. The $\mathrm{T}-1$ model had no statistically significant changes in motel occupancy across any wêtā group. Conditional $\mathrm{R}^{2}$ values remained unchanged relative to the T-0 model for all groups apart from tree wêtā overall for which it increased from 0.12 to 0.14 . 
Table 3.3 LMER model and ANOVA type 3 estimates (Pr(>Chisq)) for the effect on cavity dwelling wētā size of an increase in mammal tracking from 0 to 1 within the current and previous (T1) seasons, while controlling for Seasons and squid bait (effects not shown). Random effects were site nested within forest. Each row is a model with a different wêtā group as the response variable and the mammal index of each species as additive predictor variables. $* \mathrm{P}<0.05$. $* *=\mathrm{P}<0.01 . * * * \mathrm{P}<0.001$. Arrows indicate the direction of results deemed statistically significant at the $\mathrm{P}<0.01$ level.

\begin{tabular}{|c|c|c|c|c|c|c|c|c|c|c|c|c|c|c|c|}
\hline \multirow[t]{2}{*}{ Size } & \multicolumn{4}{|l|}{ Rats } & \multicolumn{4}{|l|}{ Mice } & \multicolumn{7}{|c|}{ Hedgehog } \\
\hline & $\beta(\mathbf{m m})$ & SE & t-value & $\operatorname{Pr}(>$ Chisq) & $\beta(\mathbf{m m})$ & SE & t-value & $\operatorname{Pr}(>$ Chisq $)$ & $\beta(\mathbf{m m})$ & SE & t-value & $\operatorname{Pr}(>$ Chisq) & Marginal $\mathbf{R}^{2}$ & Conditional $\mathbf{R}^{2}$ & Sample size \\
\hline Cave wētā & -6.7 & 4.4 & -1.5 & 0.133 & -2.4 & 8.8 & -0.3 & 0.789 & 23.4 & 11.5 & 2.0 & $0.041^{*}$ & 0.09 & 0.09 & 166 \\
\hline Tree wētā & 1.6 & 1.5 & 1.1 & 0.291 & 7.3 & 3.4 & -2.1 & $0.032 *$ & 6.6 & 4.0 & 1.7 & 0.099 & 0.02 & 0.09 & 801 \\
\hline Male tw & -0.9 & 2.3 & -0.4 & 0.705 & 9.8 & 4.8 & 2.1 & $0.040^{*}$ & 7.3 & 5.8 & 1.3 & 0.209 & 0.02 & 0.06 & 347 \\
\hline Female tw & $\uparrow 5.0$ & 1.8 & 2.7 & $0.007 * *$ & 5.7 & 4.4 & 1.3 & 0.197 & 6.4 & 4.8 & 1.3 & 0.181 & 0.05 & 0.18 & 411 \\
\hline \multirow[t]{2}{*}{ Size T-1 } & \multicolumn{4}{|c|}{ Rats (T-1) } & \multicolumn{4}{|c|}{ Mice (T-1) } & \multicolumn{7}{|c|}{ Hedgehog (T-1) } \\
\hline & $\beta(\mathrm{mm})$ & SE & t-value & $\operatorname{Pr}(>$ Chisq) & $\beta(\mathbf{m m})$ & $\mathbf{S E}$ & t-value & $\operatorname{Pr}(>$ Chisq $)$ & $\beta(\mathbf{m m})$ & $\mathbf{S E}$ & t-value & $\operatorname{Pr}(>$ Chisq) & Marginal $\mathbf{R}^{2}$ & Conditional $\mathbf{R}^{2}$ & Sample size \\
\hline Cave wētā & -7.7 & 4.9 & -1.6 & 0.115 & 6.7 & 11.9 & 0.6 & 0.573 & 12.5 & 10.4 & 1.2 & 0.231 & 0.08 & 0.09 & 159 \\
\hline Tree wētā & 0.8 & 1.6 & 0.5 & 0.601 & 3.3 & 3.7 & 0.9 & 0.375 & 4.2 & 4.2 & 1.0 & 0.310 & 0.01 & 0.08 & 731 \\
\hline Male tw & 3.8 & 2.5 & 1.5 & 0.130 & 3.5 & 5.5 & 0.6 & 0.520 & 9.2 & 6.3 & 1.5 & 0.143 & 0.03 & 0.08 & 317 \\
\hline Female tw & 1.6 & 1.9 & 0.8 & 0.408 & 4.5 & 4.5 & 1.0 & 0.318 & -0.4 & 5.0 & -0.1 & 0.943 & 0.02 & 0.16 & 372 \\
\hline
\end{tabular}


Table 3.4 GLMM model estimates for the effect on cavity dwelling wētā occupancy of an increase in mammal index from 0 to 1 in the current and previous (T-1) season, while controlling for seasons and squid bait (effects not shown). Random effects were site nested within forest. Sample size was 1017 motel observations, and the number of individuals observed is the same as for corresponding LMER models shown in Table 3.3. Each row is a model with a different wêta group as the response variable and tracking index of three mammal species as additive predictor variables. $* \mathrm{P}<0.05$. $* *=\mathrm{P}<0.01$. $* * * \mathrm{P}<0.001$. Arrows indicate the direction of results deemed statistically significant at the $\mathrm{P}<0.01$ level.

\begin{tabular}{|c|c|c|c|c|c|c|c|c|c|c|c|c|c|c|c|c|c|}
\hline \multirow[t]{2}{*}{ Abundance } & \multicolumn{5}{|l|}{ Rats } & \multicolumn{5}{|l|}{ Mice } & \multicolumn{7}{|c|}{ Hedgehog } \\
\hline & $\boldsymbol{\beta}$ & $\begin{array}{l}\text { Estimate } \\
(\%)\end{array}$ & SE & z-value & $\operatorname{Pr}(>$ Chisq $)$ & $\boldsymbol{\beta}$ & $\begin{array}{l}\text { Estimate } \\
(\%)\end{array}$ & SE & z-value & $\operatorname{Pr}(>$ Chisq) & $\boldsymbol{\beta}$ & $\begin{array}{l}\text { Estimate } \\
(\%)\end{array}$ & SE & z-value & $\operatorname{Pr}(>$ Chisq $)$ & $\begin{array}{l}\text { Marginal } \\
\mathbf{R}^{2}\end{array}$ & $\begin{array}{l}\text { Conditional } \\
\mathbf{R}^{2}\end{array}$ \\
\hline Cave wētā & -0.18 & -16.5 & 0.30 & -0.60 & 0.552 & -0.92 & -60.1 & 0.62 & -1.48 & 0.142 & -0.42 & -34.6 & 0.76 & -0.56 & 0.580 & 0.00 & 0.00 \\
\hline Tree wētā & -0.17 & -16.3 & 0.14 & -1.22 & 0.224 & $\downarrow-0.76$ & -53.3 & 0.26 & -2.92 & $0.004 * *$ & -0.15 & -14.3 & 0.37 & -0.42 & 0.677 & 0.01 & 0.12 \\
\hline Male tw & -0.31 & -26.3 & 0.22 & -1.40 & 0.163 & -0.34 & -28.9 & 0.37 & -0.91 & 0.361 & -0.09 & -8.28 & 0.55 & -0.16 & 0.875 & 0.01 & 0.06 \\
\hline Female tw & -0.10 & -8.6 & 0.20 & -0.45 & 0.653 & $\downarrow-1.16$ & -68.6 & 0.39 & -2.96 & $0.003 * *$ & -0.15 & -13.5 & 0.51 & -0.29 & 0.774 & 0.01 & 0.08 \\
\hline \multirow{2}{*}{$\begin{array}{l}\text { Abundance } \\
\text { T-1 }\end{array}$} & \multicolumn{5}{|c|}{ Rats (T-1) } & \multicolumn{5}{|c|}{ Mice (T-1) } & \multicolumn{7}{|c|}{ Hedgehog (T-1) } \\
\hline & $\bar{\beta}$ & $\begin{array}{l}\text { Estimate } \\
(\%)\end{array}$ & $\mathbf{S E}$ & z-value & $\operatorname{Pr}(>$ Chisq) & $\bar{\beta}$ & $\begin{array}{l}\text { Estimate } \\
(\%)\end{array}$ & $\mathbf{S E}$ & z-value & Pr(>Chisq) & $\boldsymbol{\beta}$ & $\begin{array}{l}\text { Estimate } \\
(\%)\end{array}$ & SE & z-value & $\operatorname{Pr}(>$ Chisq) & $\begin{array}{l}\text { Marginal } \\
\mathbf{R}^{2}\end{array}$ & $\begin{array}{l}\text { Conditional } \\
\mathbf{R}^{\mathbf{2}}\end{array}$ \\
\hline Cave wētā & -0.02 & -2.2 & 0.32 & -0.07 & 0.945 & -0.27 & -24.0 & 0.63 & -0.44 & 0.664 & -0.40 & -32.8 & 0.76 & -0.53 & 0.598 & 0.00 & 0.00 \\
\hline Tree wētā & -0.12 & -11.3 & 0.15 & -0.78 & 0.438 & -0.34 & -29.1 & 0.29 & -0.78 & 0.438 & -0.11 & -10.0 & 0.38 & -0.28 & 0.782 & 0.00 & 0.14 \\
\hline Male tw & -0.24 & -21.7 & 0.24 & -1.04 & 0.301 & 0.01 & 0.9 & 0.43 & 0.00 & 0.984 & -0.34 & -28.7 & 0.60 & -0.57 & 0.571 & 0.00 & 0.02 \\
\hline Female tw & -0.20 & -18.2 & 0.26 & -0.94 & 0.348 & -0.67 & -48.6 & 0.42 & -1.59 & 0.111 & 0.14 & 15.2 & 0.52 & 0.27 & 0.747 & 0.00 & 0.03 \\
\hline
\end{tabular}



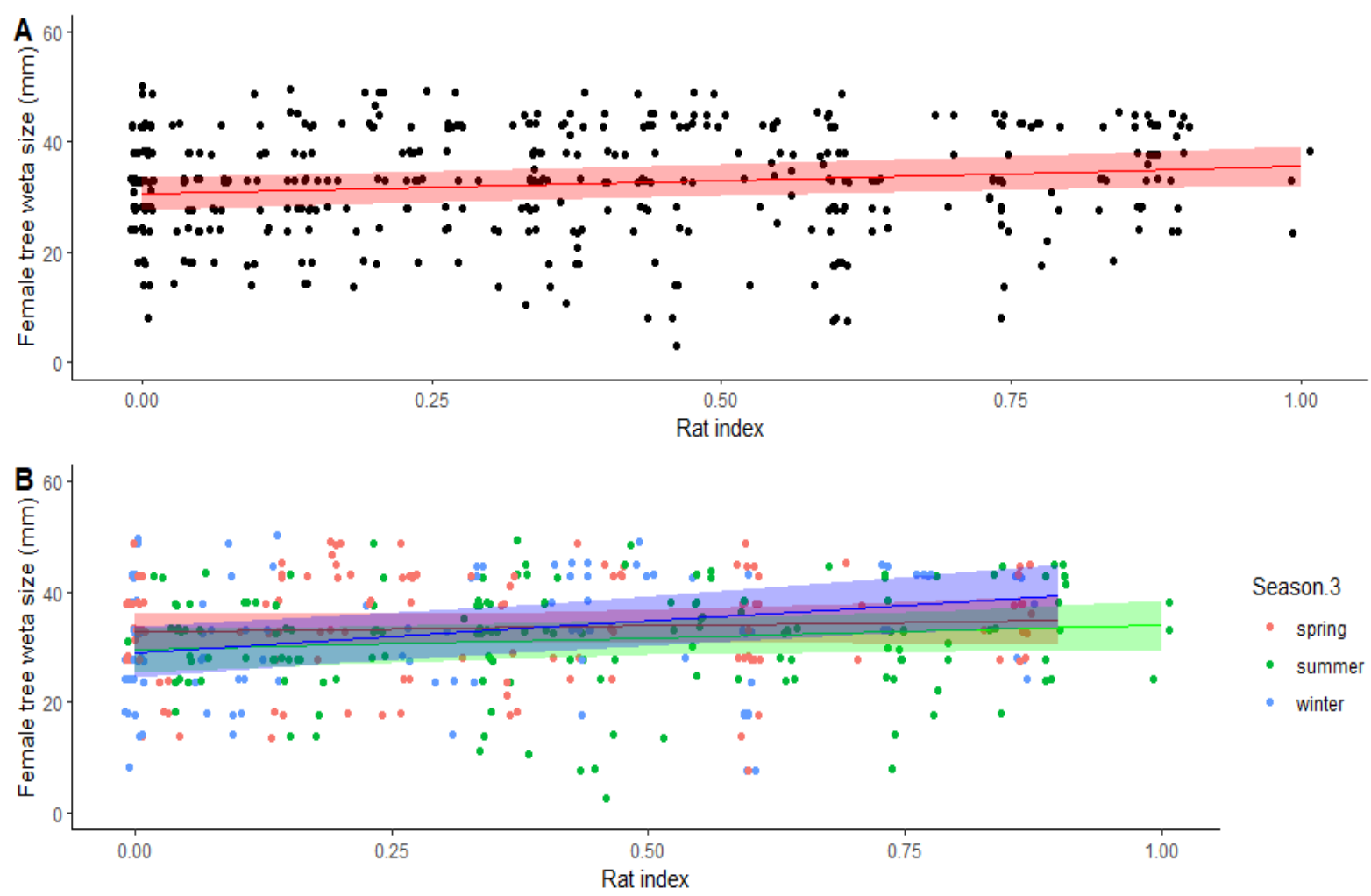

Figure 3.12 Female tree wētā size (mm) and rat index (A) including the effect of sampling season (B). Each point represents an individual wētā, points have been randomly jittered for easier visualisation of data clusters.
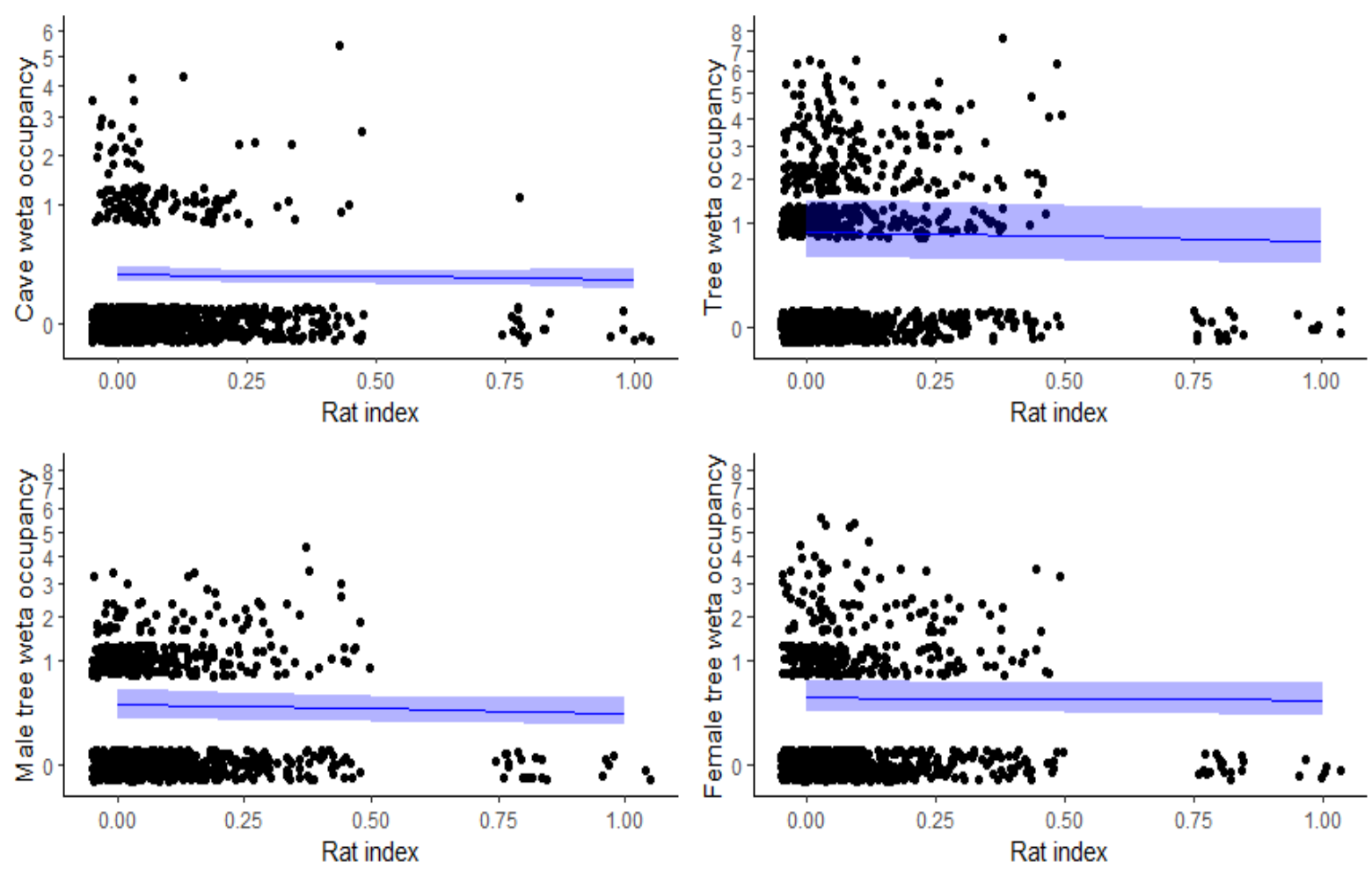

Figure 3.13 GLMM model estimates of the effect of an increase in rat index from 0 to 1, on wētā motel occupancy by group including 95\% confidence intervals. Individual data points indicate the catch in an individual pitfall, points have been randomly jittered and square root transformed to allow for easier data visualisation, y axis values have been back transformed to raw pitfall catch values. Significant $(\mathrm{P}<0.01)$ model predictions are shown in red. 

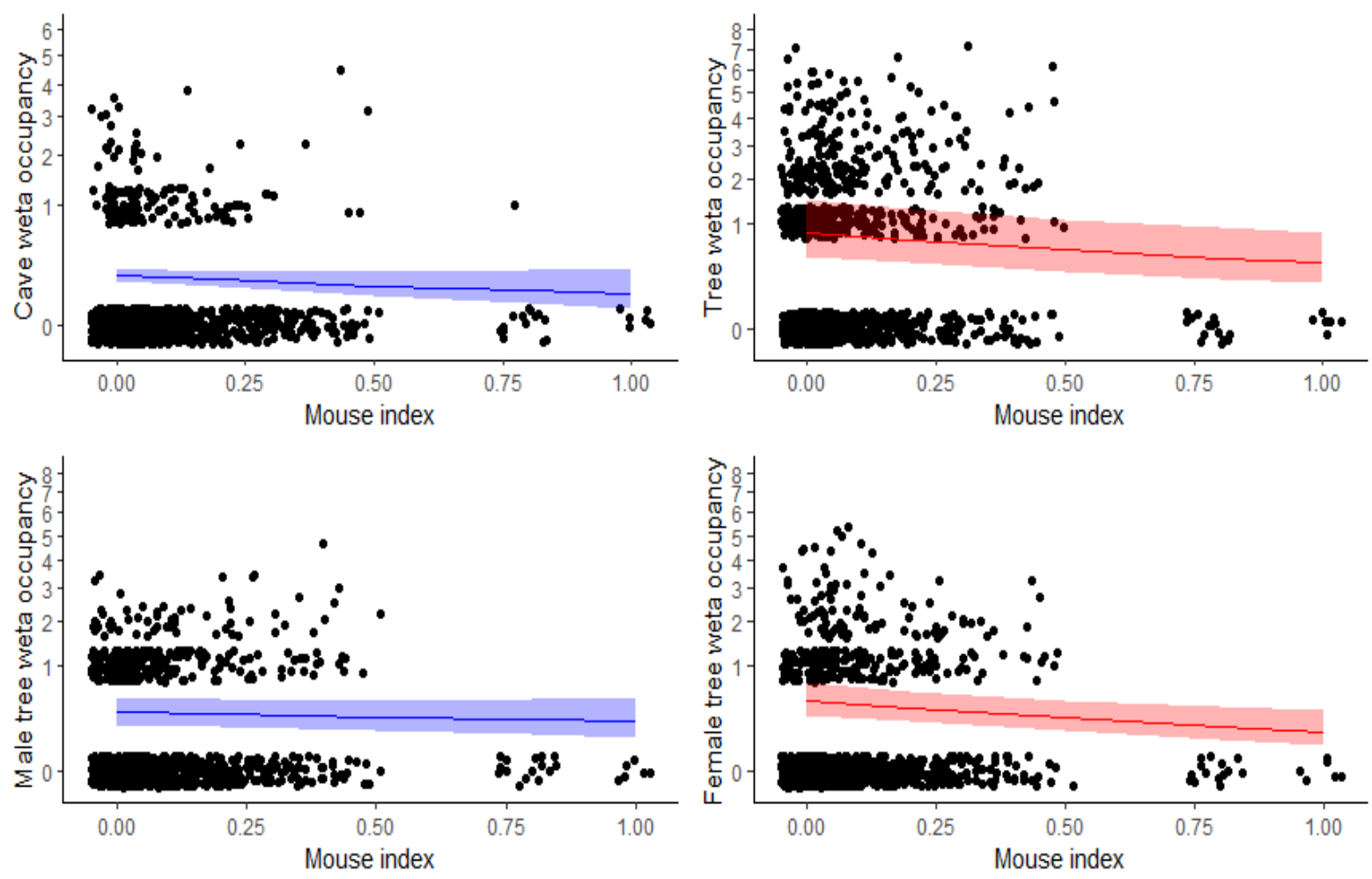

Figure 3.14 GLMM model estimates of the effect of an increase in mouse index from 0 to 1 , on wêtā motel occupancy by group including $95 \%$ confidence intervals. Individual data points indicate the catch in an individual pitfall, points have been randomly jittered and square root transformed to allow for easier data visualisation, y axis values have been back transformed to raw pitfall catch values. Significant $(\mathrm{P}<0.01)$ model predictions are shown in red.
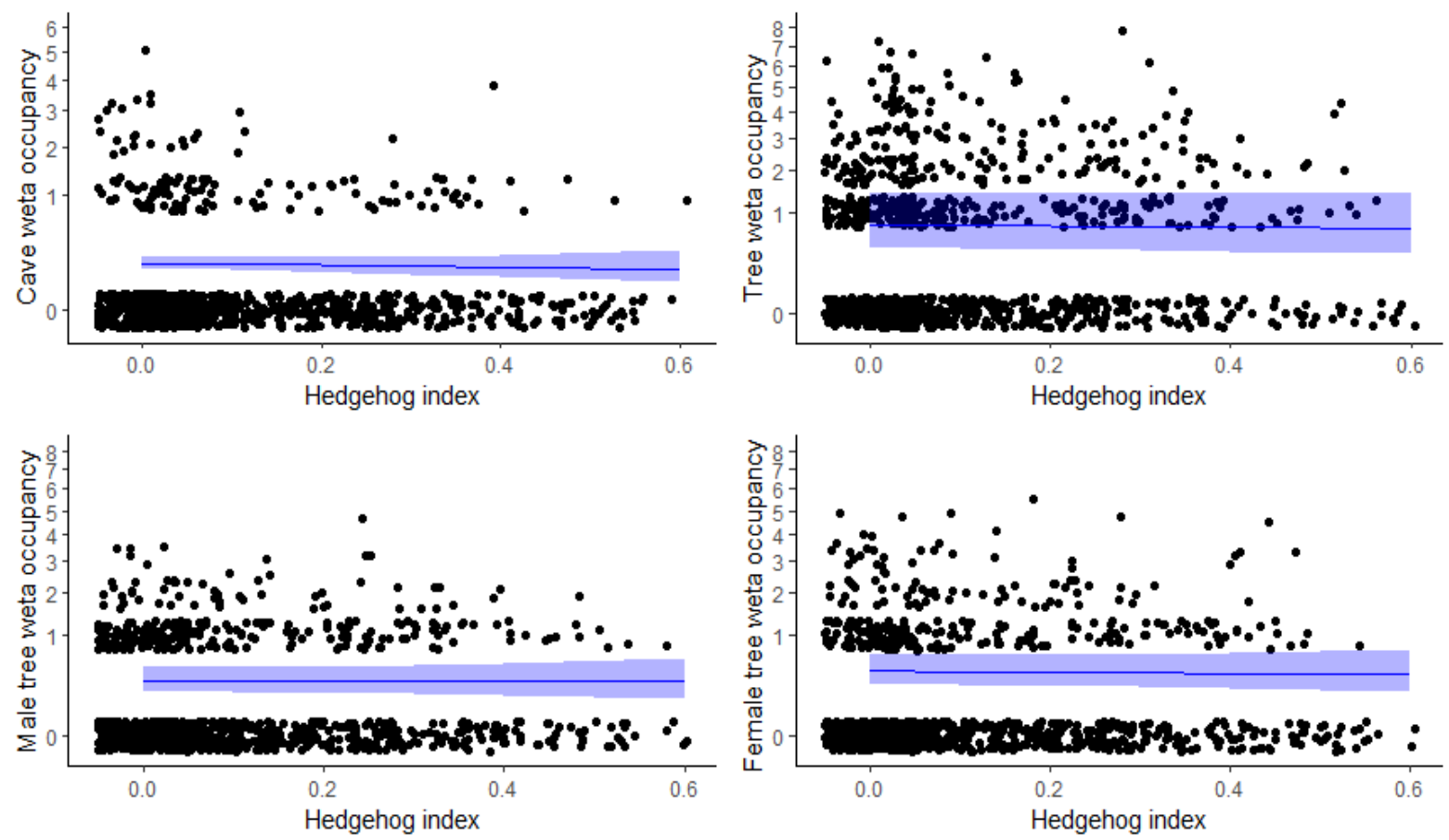

Figure 3.15 GLMM model estimates of the effect of an increase in hedgehog index from 0 to 0.6 , on wētā motel occupancy by group including $95 \%$ confidence intervals. Individual data points indicate the catch in an individual pitfall, points have been randomly jittered and square root transformed to allow for easier data visualisation, y axis values have been back transformed to raw pitfall catch values. Significant $(\mathrm{P}<0.01)$ model predictions. 

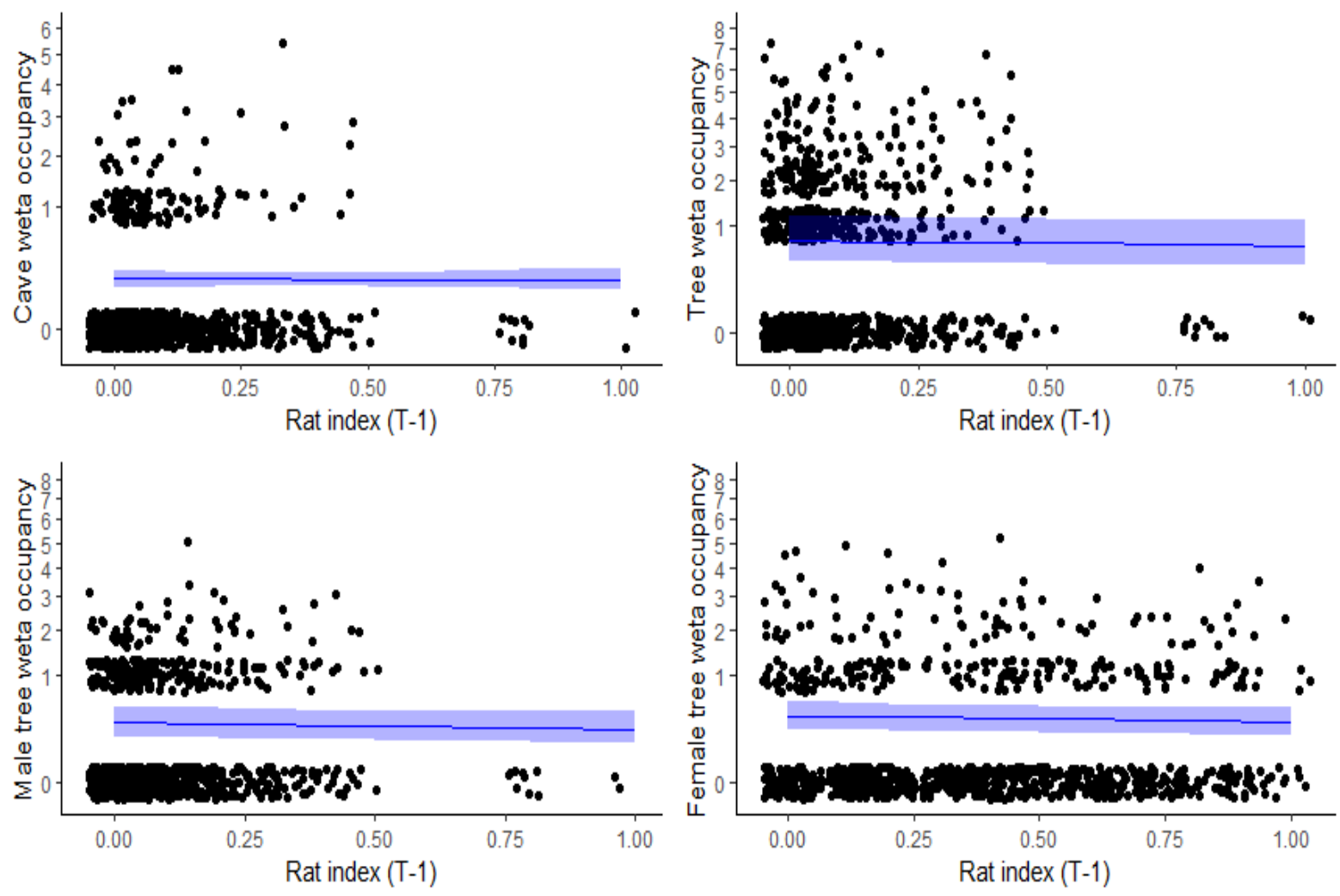

Figure 3.16 GLMM model estimates of the effect of an increase in rat index from 0 to 1 in the previous season, on wētā motel occupancy by group including $95 \%$ confidence intervals. Individual data points indicate the catch in an individual pitfall, points have been randomly jittered and square root transformed to allow for easier data visualisation, y axis values have been back transformed to raw pitfall catch values.
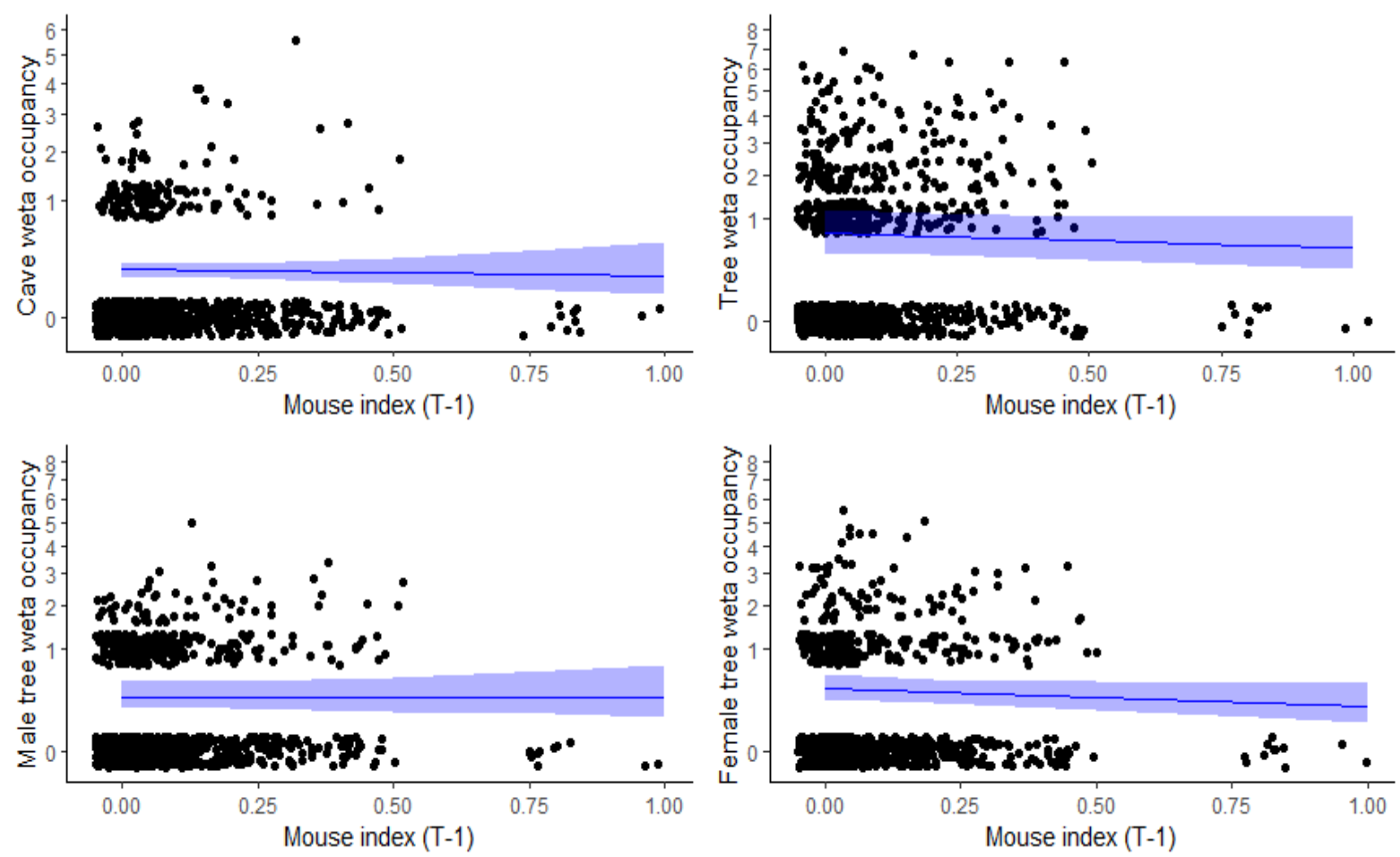

Figure 3.17 GLMM model estimates of the effect of an increase in mouse index from 0 to 1 in the previous season, on wētā motel occupancy by group including $95 \%$ confidence intervals. Individual data points indicate the catch in an individual pitfall, points have been randomly jittered and square root transformed to allow for easier data visualisation, y axis values have been back transformed to raw pitfall catch values. 

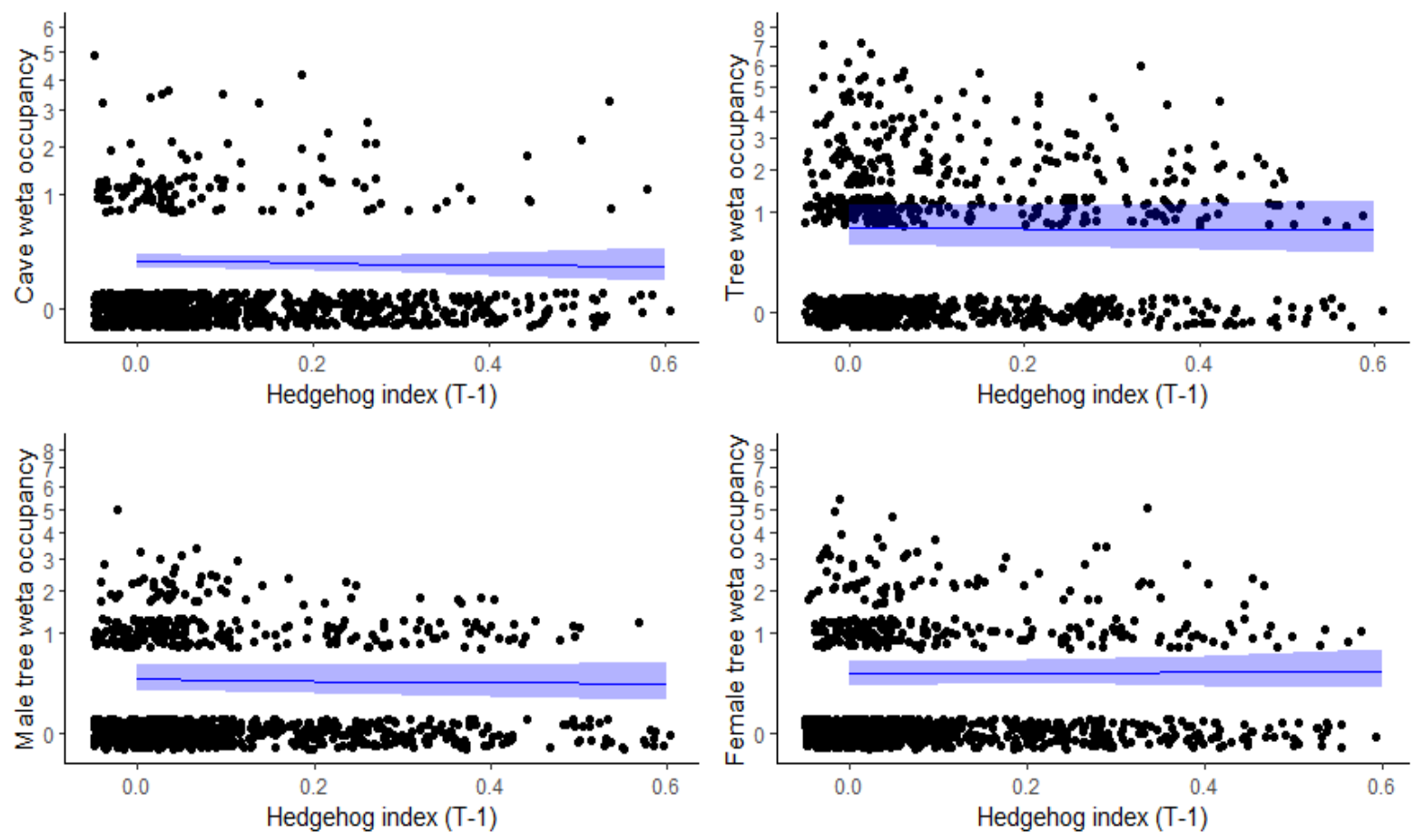

Figure 3.18 GLMM model estimates of the effect of an increase in hedgehog index from 0 to 1 in the previous season, on wētā motel occupancy by group including $95 \%$ confidence intervals. Individual data points indicate the catch in an individual pitfall, points have been randomly jittered, and square root transformed to allow for easier data visualisation, y axis values have been back transformed to raw pitfall catch values

\subsection{Discussion}

\subsubsection{Ground dwelling wētā}

There were a range of different responses to changes in mammalian predator abundance depending on the taxonomic group and mammal species examined. There were more significant results found for pitfall trapped wētā than there were for cavity dwelling wētā, potentially reflecting the greater level of vulnerability of ground dwelling invertebrates and the inherent pre-adaptive predator avoidance behaviour of cavity dwelling species (Gibbs, 1998). Rats had the strongest negative association with ground dwelling wētā catch whilst hedgehogs had a strong positive association. The responses of ground dwelling wêtā to mouse abundance was more ambiguous with a seemingly neutral response in terms of catch but significant size differences particularly in response to mammal tracking in the previous season. Cavity dwelling wêtā appeared far less sensitive to mammal predation with neutral or non-significant relationships more frequent. There was however a significant increase in the average size of female tree wêtā predicted in response to increased rat tracking as well as a significant decline in tree wētā occupancy in response to abundant mice suggesting that mammals can also exert significant influence on cavity dwelling wētā. 
The most significantly impacted group were the ground wētā. Highly statistically significant decreases in catch associated with increased rats were recorded across both the T-0 and the T1 models. This result was true of males and females in the T- 0 model and only females in the T-1 model. Cave wêtā also declined significantly in the T-1 model. This provides strong evidence for a negative impact of increased rat abundance on populations of ground dwelling wêtā. Despite this finding there were no significant relationships with ground dwelling wētā size.

Whilst there was no direct evidence of size selective pressure by rats on ground wētā there were differences in the significance of catch rates depending on demographic. Female ground wêtā had the strongest overall response to rat abundance in terms of catch in both the T-0 and T-1 models with males only declining by a statistically significant amount in the T-0 model. Juveniles also declined, but not significantly, this suggest the possibility of differences in the vulnerability of different age/sex classes of ground wêtā in response to rat predation potentially reflecting the different sizes of males, females and juveniles.

Female ground wētā are generally larger than male ground wētā (Chappell et al., 2012; Chappell et al., 2014; Gwynne, 2005) with the interquartile size of adult female ground wētā in this study recorded at between $24-28 \mathrm{~mm}$ compared with $21-24 \mathrm{~mm}$ for males. This increased size would be thought to make them more susceptible to mammal predation and there is some evidence of this from the models with a negative relationship between female wētā catch and rat tracking. Larger size in Orthoptera is often associated with a greater number of instar phases, which may increase vulnerability to predators due to the greater length of time spent moulting and increased development time before sexual maturity. In some ground wētā species females have been documented as having a greater number of instars relative to males although the exact number for $H$. pallitarsis is not known (Cary, 1981; Chappell et al., 2014; Van Wyngaarden, 1995).

Although cave wētā were not sexed, cave wētā were on average smaller in the presence of abundant rats. This combined with evidence that females are the most vulnerable group amongst ground wētā suggest that larger individuals may more vulnerable to rat predation. Pitfall trapped cave wētā were also impacted by increased rat abundance in seemingly complex ways. At the T-0 timestep rats were predicted to induce a significant increase in the average size of pitfall trapped cave wētā with a modest and not statistically significant decrease in catch. However, cave wêtā catch was more significantly impacted by the effect of the previous 
seasons rat index than they were by increased tracking within the same season. This included a $9 \%$ reduction in the overall variability predicted by the conditional $\mathrm{R}^{2}$ value indicating increased predictive power in the T- 1 model. In terms of size the effect was greater in the T-0 model with no significant decline predicted by the previous seasons rat index. By contrast ground dwelling wētā appeared to be relatively equally impacted by the effects of rat predation in the T- 0 and T- 1 models. This may reflect a difference in the timescale over which the two taxa are affected with cave wêtā showing the effect of past rat predation more strongly than ground wētā which may respond more quickly by for instance showing faster recruitment. Information on the fecundity and general recruitment of ground wētā is scarce, however female ground wētā belonging to $H$. pallitarsis have been recorded protecting clutches of between 24 to 63 eggs with a mean of 40.3 (Gwynne, 2004). This suggests the potential for reasonable levels of fecundity and population growth; comparable information on cave wêtā is not available.

The size increase in cave wêtā in response to rat populations was noteworthy as it seems to refute the hypothesis of increased vulnerability of larger invertebrates to mammal predation (Gibbs, 1998; King, 2007). The size decrease was no longer significant in the T-1 model which is surprising given the stronger decrease in catch. One possible explanation is that the reduced catch reflects the delayed indirect impacts of rats on cave wêtā such as competition for resources or the impacts of rats on cave wêtā predators. The interquartile body size of pitfall trapped cave wētā was estimated to be $8-15 \mathrm{~mm}$ however there was significant variation with some individuals being $>30 \mathrm{~mm}$ in length. Although not identified to species, the cave wētā caught in this study likely belong to a range of species which may respond differently to mammal predation or have different demographics/age structures which may have influenced the results.

The overall decline in both ground and cave wētā with increased rat tracking was to be expected as other studies have observed declines in ground dwelling wētā following mammal eradication (Watts et al., 2011; Watts et al., 2020). Although ground dwelling wētā are typically smaller than their cavity dwelling counterparts they are likely to spend more time on the forest floor which would leave them vulnerable to predation by introduced predators which forage more readily on the ground (Chappell et al., 2014; Innes et al., 2018). Although this study relies on natural observations as opposed to direct experimentation, the strength and consistency of these results allow one to be confident that the increase in rat abundance was at least partly responsible for the decreased abundance of ground dwelling cave and ground wētā. The effect 
of rat predation on size was less clear and suggests that interactions between rats and wètā are complex with individual vulnerability depending on age/sex.

As with rats, there were some size differences in some wētā classes when exposed to higher levels of mouse predation. An increase in the mouse index from zero to one was estimated to result in a small increase in the size of male ground wêtā. In the T-1 model using the previous season's mouse index, greater significance values were returned and cave wētā, male ground wētā and ground wêtā overall were estimated to be larger. This was striking as it appears to indicate that different age/sex classes of individuals respond differently to different types of mammal predators. Despite this there was no decline in the catch of pitfall trapped wētā and a modest although not significant, increase in catch associated with mice. It is possible that seasonal or demographic shifts led to the observed results with mouse tracing and wêtā size peaking at the same time of year, although season was included as a fixed effect in the model.

The reasons for increased size of male ground wētā and cave wētā in response to mice is not immediately obvious. As well as showing reduced size, male ground wētā likely differ in behaviourally from females by for instance foraging in different areas and showing different anti-predator responses (Farnworth et al., 2018). It is possible that these differences, combined with differences in the foraging behaviour of rats and mice, may leave males more vulnerable to mouse predation with females showing greater susceptibility to rat predation, as indicated by the reduced female catch rate in response to rats. It is not known whether this effects their vulnerability to mammal predation, but it may be that burrowing underground provides refuge against predation from surface active vertebrate predators or alternately, leaves them more likely to encounter predators. Males also burrow but are not thought to guard eggs (Gwynne, 2004).

Despite some slight changes in the size of pitfall trapped wētā, there was no significant effect on the overall catch of pitfall trapped wētā in response to mouse abundance. This is surprising given the strength of the association between rat tracking and invertebrate catch and the findings of other studies which have strongly suggested that increased mouse populations negatively impact ground wētā populations (Watts et al., 2011; Watts et al., 2020). It is also interesting as there were significant size differences in male wētā associated with mice which would normally suggest significant levels of predation, without any change in catch. This demonstrates the complexity of such species interactions and the difficulty in understanding exactly which variables invertebrate populations most strongly respond to. 
Unlike other more vulnerable wētā species such as giant and tusked wētā, many ground wētā species such as Hemiandrus billobatus are still relatively common in New Zealand and can even be found in environments which have experienced significant human modification (Trewick et al., 2020). This would suggest that ground wêtā generally may be more resilient to the effects of mammal predation than some other New Zealand invertebrates. In New Zealand forests, mouse populations are typically regulated by populations of other mammals such as rats which function both as predators and competitors, typically limiting mouse population density to 3-4ha ${ }^{-1}$ (Innes et al., 2010; D. Wilson et al., 2018). Although 1080 predator control operations in the Aorangi and Remutaka forests reduced rat index to $0 \%$ in some locations, these areas were typically reinvaded quickly, and it is unlikely that mice reached particularly high densities. Mean mouse index was never $>0.5$ across any site/season combination, although it did reach one across some site/line combinations.

Studies which have been able to detect an impact of mice on ground dwelling wētā have almost all come from offshore islands or fenced ecosanctuaries where mice exist in rat free environments or where mice were present in the absence of rats before eradication (St Clair, 2011; Watts et al., 2011; Watts et al., 2020; Watts et al., 2014). It is therefore likely that mouse densities in such studies were much higher than those recorded in this study and may explain why no significant result was found here. Even if densities were not higher than recorded in this study, the absence of other predators would likely mean that the effects of mice on wētā could be more easily discerned. Alternately the impact of rats may mask any impact of mice as the rats more strongly regulate ground wētā populations but also regulate mice. Therefore, any decline in rat numbers would release both mice and ground wētā and would obscure the effect of mice on ground wētā. This factor was taken into consideration in the model construction however and should be mitigated against somewhat by the inclusion of the mouse and rat term in the same model.

Hedgehog tracking throughout this study was typically far lower than for either rats or mice however there were still some significant trends predicted by the models. Most significantly ground wētā catch was predicted to be far higher when hedgehog index was high. Ground wētā were estimated to show a $236.3 \%$ increase in catch between a zero and one hedgehog tracking rate, although the index was never higher than 0.6 across any site/season combination. This result was especially strong for female ground wētā which were expected to increase by 492.6\%. This finding is unexpected as it seems to refute the hypothesis that elevated hedgehog abundance can drive the decline of invertebrates such as wētā (Brockie, 1958; Hamilton, 1999; 
Hendra, 1999; Nottingham et al., 2019). These results are highly unexpected especially when other studies have recorded significant declines in ground wêtā abundance in response to increased hedgehog abundance (Jones et al., 2013).

Hedgehogs can consume vast quantities of invertebrates over the course of a night relative to mice and rats with one study suggesting the consumption of $120 \mathrm{~g}$ of invertebrates animal ${ }^{-1}$ night $^{-1}$ (Innes et al., 2010). Another study reported the wêtā remains in $22 \%$ of hedgehog guts examined including one hedgehog which had consumed at last 47 individual ground wētā (Hemiandrus spp) in the course of one night (Jones et al., 2005). However, the impact that this level of predation has on wētā populations is not known, particularly in forest environments. Hedgehog home ranges can be large with some estimates placing them at up to 50ha suggesting that although consumption per individual may be high, overall this is mitigated by low overall density (Moss \& Sanders, 2001).

Hedgehogs are known to feed on a broad range of invertebrates depending on prey availability and may show a preference for soft juvenile prey such as lepidopteran larvae (Brockie, 1958; Hamilton, 1999; Hendra, 1999; Jones \& Norbury, 2011; Nottingham et al., 2019). The most intuitive explanation for an increase in ground wêtā with hedgehogs would be that hedgehogs respond strongly to increases in the availability of invertebrate prey, which shows up in the model as an increase in hedgehog abundance driving increases in wētā catch. This would also correlate with the previous findings for carabids which were also predicted to increase in association with abundant hedgehogs. Invertebrates often respond much more strongly to increases in resource availability and temperature than organisms at higher trophic levels (Cardoso \& Leather, 2019; Saunders et al., 2020) and it is likely that other invertebrates increase at the same time as ground wêtā which could also drive increases in hedgehogs. It is also possible that catch rates reflect the simultaneous effect of seasonality on both hedgehogs and wētā. Hedgehogs are highly seasonal and respond strongly to environmental variables such as temperature which likely leads them to become more active at times when invertebrate activity is also high, such as spring and summer (Moeed \& Meads, 1985; Stringer \& Cary, 2001). This factor was included in the models, but it is still possible that there was some residual effect unaccounted for. Another potential explanation for the increase in wētā in in response to elevated hedgehog index could be the effect of hedgehogs on other ground wētā predators such as lizards and other smaller insectivores which hedgehogs are known to consume in some situations (Jones et al., 2013). 
There was no evidence of an effect of hedgehogs on ground dwelling wētā abundance in the subsequent season suggesting the absence of any predator prey type relationship over the timescale analysed (Huffaker, 1958). This type of relationship is more likely to occur for hedgehogs than for other mammalian insect predators as hedgehogs are primarily insectivores and can consume vast quantities of invertebrates relative to mice and rats which consume other food sources such as seeds (Innes et al., 2010). Hedgehogs were also not targeted by applications of 1080, meaning that they are more likely to be at or near carrying capacity than rats and mice whose populations may not be so tightly linked to invertebrate abundance.

\subsubsection{Cavity dwelling wētā}

In comparison to ground dwelling wētā there was less evidence of an impact of mammal predation on populations of cavity dwelling wētā. The sampling methods used to monitor ground dwelling wêtā and cavity dwelling wêtā mean that the two methods are not directly comparable however it was still striking to notice the absence of any consistent trend. Female wētā residing in motels were estimated to be larger in the presence of rats whilst tree wētā overall showed reduced occupancy in the presence of abundant mice but all other mammal wētā interactions were insignificant.

Despite the limitations of using wētā motels to monitor cavity dwelling wētā abundance (Bleakley et al., 2006; Bowie et al., 2014), two significant relationships between mammal tracking and wētā size were detected. Particularly striking was the increased size of female tree wētā, estimated to be worth $5 \mathrm{~mm}$ with an increase in rat index from zero to one. This would seem to indicate the predation of smaller females by rats although there was no statistically significant decline in female tree wētā occupancy.

Typically, it is though that where rats are present there is a decline in the overall abundance of larger bodied invertebrates $>12 \mathrm{~mm}$ in size such as wētā (Campbell et al., 1984; Gibbs, 1998). However, these results point to an increase in the average size of female tree wētā. This could be an indication that juvenile or young female wētā mortality is significantly higher in the presence of rats compared to adults however as no consistent metric was used for determining the age of individuals in this study this is difficult to evaluate. Although this may show a reduction in the relative abundance of smaller bodied wētā it does not necessarily contradict the hypothesis that larger taxa are more vulnerable to mammal predation. It could be the case that the smaller juvenile stages of larger taxa are more vulnerable than other similarly sized adult invertebrates which may have developed predator avoidance responses or more chitinous 
less nutritious bodies (Blackwell, 2000). Although results vary, some studies have failed to detect any significant change in tree wētā age structure in response to mammal predation suggesting that mammal predation may not be totally responsible for these patterns (Rufaut, 1995).

The strong impact of rats on the size of female wêtā and the lack of any significant relationship between rats and male wētā within the same period is noteworthy. There are distinct morphological and behavioural differences between male and female tree wêtā such as the larger average size of females and the amount of time spent outside wētā galleries, which could influence the susceptibility to predation by rats (Bremner et al., 1989; Kelly, 2006). One study examining the impact of Kiore (Rattus exulans) removal on Stephen's Island in the Cook Straight found that tree wētā behaviour changed significantly. In the absence of Kiore, wêtā were found occupying tree cavities closer to the ground with larger entrance holes, whilst also spending more time outside of their protective galleries (Rufaut \& Gibbs, 2003). The design and placement of wētā motels used in this study with $10 \mathrm{~mm}$ or $17 \mathrm{~mm}$ entrance holes placed $1.5 \mathrm{~m}$ off the ground may make them more highly sought after in the presence of abundant rats and lead to greater competition between individuals to gain access. Although adept at climbing (Foster et al., 2011; Innes et al., 2018) rats are typically too large to enter wētā galleries. Therefore, whilst remaining inside wêtā motels wêtā are protected from mammal predation enhancing the survivability of individuals which can gain access or wander less widely.

It has been suggested that subadult females may be particularly susceptible to increased mammal predation as they may face difficulties in accessing suitable cavity spaces and can be excluded by larger competitively dominant adult males. Observations of the occupants of wētā galleries typically indicate that this is mostly made up of larger adults and relatively fewer subadults, suggesting that adults are likely to be more dominant likely due to their increased size (Moller, 1985). It is therefore possible that the increase in the average size of female wêtā in the wêtā motels reflects increased competition for access to cavities with greater protection against mammals and a selective advantage to larger individuals.

A feature of tree wētā ecology is the competitive behaviour of tree wêtā males for access to wētā galleries which often house harems of several females. Typically, male tree wètā will engage in combat for access to wētā galleries, this usually prevents more than one male wētā from occupying a gallery at a time (Wilson \& Kelly, 2019). Male tree wētā display significant variation jaw size which is thought to affect their comparative fitness and their ability to win 
bouts of male-male combat. Tree wêtā males mature at either the $8^{\text {th }}, 9^{\text {th }}$ or $10^{\text {th }}$ instar phase which determines jaw size and the mating strategy they utilise. Males that mature at the $10^{\text {th }}$ instar are the largest and hold an advantage over the smaller $8^{\text {th }}$ and $9^{\text {th }}$ instar males when it comes to access to galleries and harems of females. This causes the larger $10^{\text {th }}$ instar males to wander less than smaller males and they are therefore more likely to be found occupying wētā motels relative to $9^{\text {th }}$ and $8^{\text {th }}$ instar males (Wilson $\&$ Kelly, 2019). As males typically avoid cohabiting in the same wêtā motel it would be likely that larger males are always found in artificial wētā motels regardless of the underlying size/age structure of the male population with smaller males forced to utilise less suitable tree cavities. Males have been observed removing other wêtā from motels by clasping the hind leg of their opponent and attempting to drag them from the tree cavity and it is thought that the identity of the individual occupants of tree galleries changes frequently. This may account for the lack of a significant size response in male tree wêtā as the presence of rats is unlikely to change the competitive dynamics of male to male tree wêtā competition. These antagonistic encounters occurs more frequently between males which will then face off in a bout of combat, but males have also been observed removing female wētā from tree cavities (Carpenter et al., 2016; Fitness et al., 2015; Moller, 1985).

Sex ratios in the general population are thought to be roughly equal and whilst males remain longer in galleries with multiple females it is just as, if not more, common to find male tree wêtā cohabiting with a single female (Kelly, 2006; Wehi et al., 2013). Females are thought to be more sensitive to the effects of mammal predation and elicit a stronger anti-predator response which may in this instance manifest in a greater preference by female wētā for more protected cavities (Wilson \& Kelly, 2019). Females likely have more freedom to do this as they are not as constrained by competition for gallery space, although females do also tend to avoid cavities already occupied by females (Wehi et al., 2013).

Results from other studies have tended to suggest a negative overall impact of rodents and mammals on tree wētā and often this has more strongly impacted on female tree wêtā (Moller, 1985; Rufaut, 1995; Rufaut \& Gibbs, 2003; Watts et al., 2011). Although there was no significant decrease in the occupancy rates of male or female tree wētā this could be masked by other factors relating to habitat type or upper limits on motel occupancy which limit occupancy scores more than other monitoring methods such as pitfall trapping. It is therefore possible that the size difference in females reflect the effects of increased predation and may suggest reduced wētā abundance. More accurate methods of measuring wētā density such as 
mark recapture would be required to confirm this however this was beyond the scope for this study.

Despite differences in the size of female tree wêtā in response to rat index there was no statistically significant effect on the occupancy rate of cavity dwelling wêtā. This may reflect other factors linked to motel occupancy such as the availability of large tree cavities elsewhere, therefore motel occupancy may not be able to detect subtle changes in population density (Bleakley et al., 2006; Trewick \& Morgan-Richards, 2000). It has also been suggested that tree wêtā are most vulnerable to rats when rat density exceeds $4 \mathrm{ha}^{-1}$ and below this it is difficult to detect changes in tree wêtā abundance which may indicate that average, rat densities in this study were typically below this threshold (Norbury et al., 2015; Ruscoe et al., 2013). The increased size of female wētā in response to increased rat tracking strongly suggests a direct or indirect effect of rats on female wētā despite the lack of a clear decline in occupancy.

The impact of rat predation of cave wêtā did not produce changes in the size or occupancy of cave wētā in wētā motels. This differs from the result of pitfall trapped cave wētā which were predicted do decline both in terms of catch and size. Whilst there is a significant body of knowledge relating to the ecology and behaviour of tree wêtā, far less is known about cave wētā (Carpenter et al., 2016; Fitness et al., 2015). Cave wētā can refer to over 50 different species and behaviour differences between species are poorly understood. It is not known whether the species caught in pitfall traps represent the same species as those recorded in wētā motels. The lack of any significant decline in occupancy of cave wētā has been reported elsewhere in response to rat predation (Ruscoe et al., 2013). This seems to differ between pitfall trapped cave wētā where there are examples of reported declines in cave wētā catch associated with mammal predation (Watts et al., 2011; Watts et al., 2020) and may reflect differences in the monitoring methods, species identity or behaviour of cave wētā surveyed with each method.

Overall, increased mouse tracking did not seem to predict the size of cavity dwelling wētā. Male tree wētā and tree wētā overall were predicted to be larger but this did not achieve statistical significance. Tree wētā occupancy rates overall were predicted to decline in response to increased mouse predation. Females were also predicted to decline significantly however males were not. This indicates that female wētā may be more vulnerable to increased mouse abundance. This broadly aligns with the hypothesis proposed by Moller (1985) which suggested that female wētā might be more vulnerable to predations because they must come to the ground to oviposit. 
Size differences in male wêtā exposed to mouse predation have been observed in Hemideina trewicki (Hawkes Bay tree wētā) which also inhabit tree cavities and have similar behavioural and niche requirements to $H$ crassidens (Dent, 2016). The model used in my analysis did predict slight, almost significant, increases in the size of male tree wētā and tree wētā overall suggesting the possibility of increased size associated with mice. Tree wêtā from the similar Hemediena thoracica were the most frequently encountered food source in the gut content of mice caught on Rangitoto island in the Hauraki gulf (Miller \& Miller, 1995) demonstrating that tree wētā can be a significant portion of a mouse's overall diet and that mice are likely a major predator of Hemediena crassidens. The preferred prey size of mice is typically thought to be between 3-12mm (Ruscoe, 2001) which is far below the average size of $H$ crassidens observed in the wētā motels across any age/sex group although mice will also take much larger prey in some cases up to $30 \mathrm{~cm}$ and juvenile tree wêtā can also be <12 mm (Norbury et al., 2014). This seems to suggest that smaller tree wētā are more vulnerable than large tree wêtā and corresponds with the increased average size of male pitfall trapped ground wētā in response to mice.

Relatively few juveniles in a population typically indicates a stable or declining population (Rufaut, 1995). Although fewer juveniles can indicate increased predation pressure, it can also indicate reduced recruitment and fecundity which does not necessitate that juveniles be directly predated upon for their relative abundance to decrease. If fecund adults are most vulnerable this can lead to similar patterns. Adults are likely more vulnerable once they leave the safety of the gallery to lay eggs or feed on the ground, this would likely reduce the number of eggs laid and therefore the number of juveniles in subsequent generations. There was however no corresponding signal in the following season, with the T-1 model showing no significant effects which one might expect to see if mice were reducing recruitment. It is also possible that changes in recruitment may not show up in the models until later such as in the T-2 or T-3 timestep as young wētā mature into adults however this was not analysed in depth. The reduction in female tree wētā occupancy suggests that overall recruitment may be impacted by mice and it is striking to note the large though not significant increases in size of the tree wêtā overall. This suggests that there may be reduced recruitment during periods of high mouse density due to the excess mortality amongst females and therefore fewer small individuals.

Although theoretically possible, it is unlikely that mice would be able to predate on tree wētā inside motels. The size of the largest entrance hole for each wētā hotel was $17 \mathrm{~mm}$ which is small enough to provide protection against mice which typically do not enter motels with an 
entrance diameter $<17 \mathrm{~mm}$ (Bleakley et al., 2006). Mice are able to climb trees and have been observed up to $11 \mathrm{~m}$ off the ground, but may be restricted to ground based foraging in the presence of other rodents such as rats (Innes et al., 2018). Although wētā motels have often been used as estimates of wètā population density it is unlikely that it reflects a perfect one to one relationship with wētā populations and other factors such as availability of other large tree cavities and canopy density are also known to influence wētā occupancy rates (Bowie et al., 2014). It was not quantified in this study, however there is considerable variation in the habitat type and canopy density of the various monitoring lines ranging from old growth beech and podocarp forest to tall manuka/kanuka scrub which likely effects wētā occupancy rates. This is negated by the fact that this was a longitudinal study and habitat is unlikely to have changed significantly during the study period allowing comparisons temporally rather than spatially. Habitat type may also affect the vulnerability of cavity dwelling wētā to mammals by influencing the size and quantity of cavities and therefore the relative preference for artificial motels.

Mouse abundance in this study was thought to be relatively low as the mean mouse index was typically below 0.5 . Although it is difficult to assess how these scores relates to overall mouse density it strongly indicates that mouse tracking was lower than is typical on offshore islands and ecosanctuaries where rats are absent. It is also possible that mouse tracking may be influenced by the presence of rats in tracking tunnels as mice are known to avoid areas frequented by rats and are wary of rat scent although they do display neophilia (Brown et al., 1996). In any case it is difficult to know precisely how wētā are impacted by mice at different densities as the impacts at low mouse densities may be negligible with significant effects only detected at higher densities as they are for rats (Norbury et al., 2015).

Indirect competitive interactions may also occur between mice and Tree Wêtā and both are of may occupy similar ecological niches. The lack of any indigenous rodents in New Zealand has led some to suggest that wētā, in particular those in the genus Deinacrida may be functionally similar to mice, both are of similar size and are able to utilise a range of food sources (Diamond, 1990). Others have suggested this is a relatively loose comparison due to the significantly large discrepancies in rates of reproduction and metabolic rate (Griffin, Trewick, et al., 2011). Most of the knowledge about the diet of tree wêtā come from the $H$. thoracica which is omnivorous but with herbivory thought to make up the majority of its diet (Brown, 2013). H. crassidens is less well studied but is similarly known to be omnivorous with both plant material and invertebrates consumed by $H$ crasidens under laboratory conditions (Griffin, Morgan- 
Richards, et al., 2011). This would suggest significant dietary overlap between mice and tree wētā.

No significant differences in the size or abundance of cavity dwelling wêtā and hedgehog tracking were detected across either the T-0 or the T-1 model. The T- 0 model did predict an increase in the size of tree wêtā overall, estimated to be worth $7.8 \mathrm{~mm}$, which was almost significant. Although hedgehogs are known to consume tree wêtā (Brockie, 1958; Jones et al., 2005; Nottingham et al., 2019) it is not known if they represent a preferred food source for hedgehogs. Hedgehogs are capable of climbing trees however they typically forage on the ground (King \& Forsyth, 2021), a habit which likely reduces the number of encounters they have with tree wētā relative to rats and mice which may occasionally encounter tree wētā on tree trunks/branches. The lack of any significant relationship likely reflects the reduced susceptibility of tree wētā to hedgehog predation relative to ground dwelling invertebrates.

The number of individual wētā (cave and tree) observed and matched to mammal tracking values in wētā motels was lower than the number of wētā caught in pitfall traps. A total of 890 wètā (731 tree wētā, 159 cave wētā) were observed in wētā motels compared with the 1722 (1207 ground wētā, 515 cave wētā). This will have reduced the significance of any observed difference and may explain why no significant values were obtained for cavity dwelling wētā and hedgehogs. Wētā motels are also likely to be a less accurate measure of overall wētā abundance given that there is a limit to the number of wêtā which can fit in a motel and the antagonistic nature of tree wētā which effects occupancy rates. Therefore, relative to pitfall traps wētā motels are likely less likely to show changes wêtā populations with occupancy and size responding in non-linear ways due to other limitations on wētā occupancy.

Hedgehog tracking was significantly lower than for either mice or rats and the results of pitfall trapping suggest that local hedgehog abundance may be driven by invertebrate abundance. As with rats and mice it is difficult to relate hedgehog index to overall density estimates and it may be that hedgehog abundance was not great enough to induce responses in the size or abundance of tree wētā. It seems unlikely that they would represent a preferred food source particularly if there is smaller or more convenient ground dwelling prey such as lepidopteran larvae or beetles available (King \& Forsyth, 2021). Although tree wētā remains have been found in the stomachs of hedgehogs in significant numbers, this may reflect the conspicuousness of wêtā remains in stomachs as much as it does hedgehog prey preference. The remains of ground wētā are typically far more commonly encountered in hedgehog 
stomachs than tree wētā which also corresponds with the results reported here (Brockie, 1958; Hamilton, 1999; Hendra, 1999; Jones et al., 2005; Nottingham et al., 2019).

Overall, there was no evidence of change in hedgehog abundance related to tree wētā occupancy and it seems unlikely that tree wêtā are a major resource for hedgehogs in forest habitats. It is likely that the cavity roosting tendencies of tree wētā and some cave wētā provide some protection against hedgehog predation and direct predation by hedgehogs on tree wētā is likely to be opportunistic rather than targeted.

$\mathrm{R}^{2}$ values recorded across all cavity dwelling wêtā species and sex categories were routinely low for both the size and abundance models $(<0.18)$ suggesting that there is still a significant proportion of the overall variation in wētā size and occupancy unaccounted for by the model. This suggests that although there is likely some impact of rat populations on the size of wētā in wētā motels there are likely to be many other factors such as temperature, humidity, habitat type and altitude which likely have a larger overall impact on cavity dwelling wêtā (Bulgarella et al., 2015; Norbury et al., 2015). Pitfall trapped wētā returned generally higher $\mathrm{R}^{2}$ values suggesting that mammal predation is a stronger predictor of ground dwelling wêtā size and abundance than it is for cavity dwelling wētā.

\subsubsection{Conclusions}

The effect of mammals on ground dwelling wētā was complex, with the tracking rate for each of the three mammals examined showing different associations with wētā catch. In response to increased rat tracking, the models predicted significant declines in catch for both ground and cave wētā however there was no association with mice and there were some strong increases in catch associated with increased hedgehog tracking. These results demonstrate the complexity of mammal invertebrate interactions and the difficulty in understanding the precise ways in which mammal populations impact on invertebrate populations without experimental data.

There were some significant differences in size of some of the wêtā groupings however these were highly variable in their strength, direction and timescale so it is therefore difficult to conclude unequivocally that these results were explicitly the result of mammal predation. The results of this study also differ substantially from other studies which have typically suggested that mice and hedgehogs can have substantial negative impacts on wētā populations (Jones et al., 2005; Watts et al., 2011; Watts et al., 2020). This likely reflects differences in study design 
as other studies have typically been in more experimental conditions where mammals could be completely eradicated (Watts et al., 2020; Watts et al., 2014) as opposed to natural studies such as this one where mammals are at best periodically controlled. It is likely that the response of ground dwelling wêtā to mammal predation in New Zealand is highly complex and context specific depending on the habitat and mammal populations densities at the study site. Further study of mammalian prey choices in different habitats and wētā life histories will be required to further understand these interactions.

There were fewer significant relationships between cavity dwelling wētā sizes and abundance relative to the pitfall trapped invertebrates. This may reflect the difference in monitoring methods which prevents direct comparison or the reduced susceptibility of arboreal invertebrates. Despite this there was a predicted increase in the mean size of female tree dwelling wētā in response to increased rat abundance and a decrease in the occupancy rate tree wêtā in response to increase mouse abundance. Analysis of the literature suggests that the relationship between wētā occupancy rates, size and mammal tracking is complex and the results presented here are likely to represent a combination of direct predation and the effect of differences in behaviour between male and female wētā in response to the presence of mammals (Rufaut, 1995; Rufaut \& Gibbs, 2003; Ruscoe et al., 2013). The responses of cavity dwelling wētā to mammal predation are likely to be far more complex than simple predator prey relationships and further research will be required to understand these relationships fully. 


\section{General discussion}

\subsection{General observations}

In seeking to understand whether introduced mammals reduce the size and abundance of New Zealand forest invertebrates, several interesting, and in some cases surprising results, were found. Increased mammal tracking rates resulted in variable changes in average invertebrate size depending on the invertebrate taxa and mammal predator examined. Whilst in most instances there was no significant difference in the size of invertebrates in response to mammals, there did appear to be a trend for increased size in some ground wêtā in response to mice and an increased vulnerability of female tree wētā to mice. The impact of mammalian predators on invertebrates has typically been thought to impact more strongly on larger taxa (Angel et al., 2009; Gibbs, 1998; Giribet \& Boyer, 2010; Kuschel \& Worthy, 1996; Leschen et al., 2012; Norbury et al., 2015; Watts et al., 2011). Therefore, it would seem logical to expect a decrease in the mean observed size of invertebrate taxa with an increase in the occurrence of mammals. However, this appears to be an oversimplification of mammal invertebrate predatorprey dynamics.

In addition to the impact on size there were some notable changes in pitfall catch and motel occupancy suggesting that mammals also impact on the relative abundance of forest invertebrates. Strong evidence was found for the negative impact of increased rat populations on pitfall trapped beetles and wētā and a positive association between increased hedgehog tracking and ground dwelling invertebrate catch. Mice also appeared to negatively affect the catch (or occupancy) of certain invertebrate groups such as Carabaeidae, Scarabaeidae and tree wētā. These complex responses may reflect a range of environmental factors as well as predation, but demonstrate the complexity of understanding mammal-invertebrate relationships in New Zealand.

The declines in invertebrate abundance reported here are consistent with evidence elsewhere where wêtā and beetle declines have been observed in response to increased rat predation ( $\mathrm{St}$ Clair, 2011; Watts et al., 2011; Watts et al., 2020; Watts et al., 2014). The size, significance and consistency of the effect of rats across all the pitfall trapped invertebrate categories was significant, and not entirely unexpected given the impact of mammal predators on New Zealand endemic vertebrates and other wildlife (Gibbs, 2009; Innes et al., 2010). Nonetheless, in some studies it has been difficult to detect invertebrate population changes in response to 
mammals (Rate, 2009; Rickard, 1996; Vergara, 2018). This likely reflects the difficulty in adequately sampling invertebrate populations, identifying individuals to species or genus level, disentangling the impact of environmental variables on invertebrate populations as well as, presumably, instances where invertebrate populations are resilient to mammal predation.

The relationship between increased hedgehog tracking and pitfall trapped invertebrates was far more striking with a greater catch of carbids, scarabs and ground wêtā associated with an increase in the detection of hedgehogs. This was highly unexpected due to their insectivorous diet and prolific invertebrate consumption, but is consistent with bottom up regulation of hedgehog populations by invertebrate communities and/or behavioural targeting by hedgehogs of places and periods of high invertebrate abundance (Hamilton, 1999; Hendra, 1999; Innes et al., 2010; Jones et al., 2005; Jones \& Norbury, 2011; Jones et al., 2013; Nottingham et al., 2019).

In general, across all taxa, it was rats which were predicted to produce the most consistent responses in pitfall trapped invertebrates. Rats are typically thought to be among the most destructive introduced mammals in New Zealand and have detrimental impacts on the populations of a range of native organisms so their impact on invertebrates is not surprising (Innes et al., 2010). Rats were by far the most frequent mammal taxa recorded, with large fluctuations in tracking rate between years and locations. Result for mammal tracking are therefore the most likely as rat densities and therefore rat predation is highest. Mice have much smaller home ranges, and can achieve much higher densities, up to $45 \mathrm{ha}^{-1}$ under the right conditions (D. J. Wilson et al., 2018), whilst hedgehogs typically persist at lower densities with large territories though to be between 2-50ha (Brockie, 1958; King \& Forsyth, 2021; Moss \& Sanders, 2001).

Although larger invertebrate taxa are likely the most vulnerable to mammal predation, it may be the case as with larger and long-lived vertebrate taxa, that the greatest threat to invertebrates is to juveniles, larvae and eggs rather than to adults (Holdaway, 1989). This would explain why there was sometimes an increase in the average size of some invertebrates, but there was not always a corresponding decline in catch or occupancy rate measured over a timescale of less than one generation. Organism size often corresponds with life history traits such as a greater number of instars, flightlessness and lower fecundity. Therefore, it may be these traits, rather than absolute size per se, that is responsible for the vulnerability of larger invertebrate taxa. 
Increased mouse tracking also corresponded with a reduced catch for pitfall-trapped carabids and scarabs but did not appear to reduce the catch of pitfall-trapped wētā, Staphylinidae or other beetles. It is likely that the impact of mice on invertebrates is suppressed in mainland environments such as the Aorangi and Remutaka ranges where rats regulate mouse populations, although mice are known to significantly impact on invertebrate communities on islands and in fenced ecosanctuaries (Angel et al., 2009; Russell et al., 2020; Watts et al., 2011; Watts et al., 2020). Despite the relatively low mouse index throughout the study there were still highly significant associations with invertebrate size and abundance. Mice are known to feed heavily on invertebrates in accordance with relative invertebrate density particularly in the warm summer months and may be more likely to feed on invertebrates in accordance with their overall abundance (Russell et al., 2020). Carabid and Scarabaeidae catch declined however Staphylinidae catch did not decline significantly in response to increased mouse tracking. This has been reported elsewhere where Staphylinidae have become relatively more abundant than other beetle taxa (non Staphylinidae) in response to increased mouse populations potentially indicating that Staphylinidae are less sensitive to mouse predation (Vergara, 2018; Watts et al., 2020).

It is interesting to observe that there was no corresponding relationship between mice and ground dwelling wētā catch. This was somewhat surprising given that mice have been recorded in other locations consuming the larger tree wētā in significant numbers and would be expected to consume ground wētā also (Miller \& Miller, 1995). It may be the case that the effects of mice on ground wētā predators may indirectly allow ground wētā abundance to increase but it is not obvious which predators these would be. Some species of ground wētā persist in a range of human modified habitats where rodent populations are high so it is likely that they have some level or resilience to predation (Nboyine et al., 2016; Trewick et al., 2020). It is also possible that the nimbler and generally faster moving ground wētā can more easily avoid mouse predation although the results presented here indicate they do appear to be vulnerable to rats. The most likely cause of a lack of a response is that mouse populations were not high enough to significantly impact on wētā populations (Norbury et al., 2015).

Hedgehog tracking was also correlated with increases in catch of pitfall trapped carabids, scarabs and ground wêtā. Whilst indirect mediation of other invertebrate species may account for this phenomenon, the most likely explanation is that invertebrate abundance is a driver of hedgehog density rather than vice versa. Hedgehogs can have large ranges and can wonder large distances in search of food (King \& Forsyth, 2021; Moss \& Sanders, 2001). It is therefore 
likely that tracking tunnels with a 50m spacing, as utilised in this study, may only capture local hedgehog activity, which may increase with invertebrate activity, rather than reflecting population density. There are examples in the literature where large aggregations of hedgehogs have been described when there is an abundance of invertebrate prey (Brockie, 1958; Parkes, 1975). This does not rule out the possibility that hedgehogs may have a significant impact on invertebrate populations, however likely suggests that bottom up regulation of invertebrate communities a larger driver of overall abundance than top down hedgehog predation, at least for the taxa examined here (Jones et al., 2013).

This strength of this association is also likely impacted somewhat by the seasonal abundance of both hedgehogs and invertebrates whose activity is strongly influenced by temperature. This bottom up regulation of hedgehogs is made more likely by the lack of significant predator control efforts explicitly targeting hedgehogs in the Aorangi and Remutaka Ranges. Although 1080 is highly toxic to hedgehogs the application of 1080 in winter likely misses hedgehogs in most instances (Dilks et al., 2020). There is some evidence that hedgehog populations may have been reduced in the 2018 treatment in the Aorangi ranges and by the 2019 application in the Remutakas, as declines in hedgehog tracking appeared to coincide with these applications, but it is difficult to attribute this solely to 1080 as hedgehog tracking was routinely low, see Figure $6.1 \& 6.2$ in the appendix. If hedgehogs were not significantly impacted by 1080 applications, then it indicates that density is more likely to be regulated by environmental variables such as resource availability, compared with rats and mice which experience period populations knockdowns by 1080 . This factor also suggests that the observed effect is related to invertebrate prey availability rather than top down regulation by hedgehogs.

New Zealand's relatively mild climate allows many invertebrate species including carabids to breed all year round (Hutchison, 2007) which may lessen the impact of elevated hedgehog density as hedgehogs are only active for part of the year. It is also likely that in a damp elevated terrain of the Remutaka and Aorangi forest sites $(150-800 \mathrm{~m})$ hedgehog density is further limited relative to other habitat types such as open pasture (Foster et al., 2021; King \& Forsyth, 2021). Olfactory-cued predators of invertebrates were, and in some areas still are, a significant part of the indigenous fauna in New Zealand in the form of kiwi (Castro et al., 2010). It is possible that exposure to these predators may have allowed some native invertebrate species to evolve responses which have left them resilient to the impacts of hedgehogs and other mammals which hunt primarily by smell (Gibbs, 2010). 
There were fewer and less consistent trends for the effect of introduced mammals on the size of cavity dwelling wêtā when compared with pitfall-trapped invertebrates. Part of this is likely due to the reduced vulnerability of arboreal species which are less likely to encounter ground foraging mammal species such as rats and mice (Gibbs, 1998). Mice tracking however did appear negatively associated with overall tree wêtā occupancy. This relationship has been suggested elsewhere and mice have been known to consume large quantities of tree wētā in certain environments (Miller \& Miller, 1995). Interestingly it appears that the demographic grouping most vulnerable to mouse predation was females. This is particularly interesting given that females are generally larger than the preferred prey size of mice but does provide evidence that large invertebrate taxa such as tree wētā may be more vulnerable to mouse predation.

The lack of many significant relationships between tree wētā occupancy rate and rat abundance likely has multiple explanations. To some extent this may reflect the resilience of tree wêtā to rat predation as tree wêtā are found in a range of habitats where they are exposed to rat predation and these populations seem to be mostly sustainable (Dent, 2016; Rufaut, 1995; Rufaut \& Gibbs, 2003; Watts et al., 2017). The arboreal nature of tree wētā and their preference for cavity roosting both likely contribute to reduced vulnerability to mammal predation as rats, mice and hedgehogs are primarily ground foragers although they are also capable of climbing trees (Foster et al., 2011; King \& Forsyth, 2021). Tree wētā are known to be impacted most severely by rat populations $>4 / \mathrm{ha}^{-1}$ and it may be the case that racking recorded here, infrequently reached such levels despite regularly recording tracking rates of one (Norbury et al., 2015). There are also limitations to using wêtā motels to infer wêtā populations, as occupancy can be influenced by factors such as canopy cover which may make them a relatively imprecise measure of overall wētā density (Bleakley et al., 2006; Bowie et al., 2014; Trewick \& Morgan-Richards, 2000).

Whilst the impact of introduced mammals on indigenous invertebrates is often assumed to be negative, it has often been difficult to demonstrate this empirically. Most of the evidence of depletions of invertebrate fauna resulting from mammals have either come from studies on predator free islands, ecosanctuaries or inferred by the absence or extinction of expected species. Studies on the mainland have not always been able to demonstrate evidence of an effect (Dent, 2016; Rate, 2009; Ruscoe et al., 2013; Vergara, 2018; Watts et al., 2011). This possibly reflects the difference between suppression and eradication of introduced mammals as well as the limited duration of most studies of invertebrate response to mammal removal on the mainland, which have been short in duration typically only lasting for a few seasons. Given 
the highly variable nature of invertebrate populations in response to bottom up environmental variables it would likely take longer for general trends to appear, particularly in mainland environments where there is generally a suite of introduced mammalian predators which interact and can lead to cascading complex changes in ecological communities (Tompkins et al., 2013; Tompkins \& Veltman, 2006). The results reported in this study took a long time to appear with prior analyses of invertebrates (2013-2015) failing to produce significant results. Previous research by (Vergara, 2018) using some of the same invertebrate specimens as this study failed to find significant changes in beetle communities but did report a decrease in ground wētā catch in association with rats. Vergara also reported a decline in ground wētā size in association with rats however no such finding was found here. This demonstrates the complexity of mammal invertebrate interactions and the importance of long-term observations in understanding community change.

Some of New Zealand's invertebrates are thought to be particularly long lived and this could also be a potential source of the variation in invertebrate size recorded in this study. Long lived species may be able to persist for longer in the environment despite low or minimal recruitment if adults survive into old age. Tree wētā for instance can live up to 3 years (Bulgarella et al., 2015; Rufaut \& Gibbs, 2003) and New Zealand carabids can live for $>1$ year, but precise estimates of overall lifespans are not available (Cartellieri \& Lövei, 2003; Hutchison, 2007; Leschen et al., 2012). This phenomenon could also present as an increase in the average size of invertebrates as new individuals are not recruited to the population. It may be the case that at the times of year when mammals are most abundant i.e. summer, invertebrates also reach their largest size. Although seasonality was included in the model predictions this is still an important factor to consider.

\subsection{Species observations}

The diversity of pitfall-trapped Coleoptera recorded in this study was substantial, with 134 different taxa assigned tag names. Only 30 of these could be reliably identified to species level of which the best described family were carabids and, predictably, the least well described category was other beetles. There is also the strong possibility of species complexes existing within these taxonomic labels and the species list recorded in the appendix likely reflects only a portion of the overall diversity found within these forest sites.

Studies of invertebrate communities and mammal predation have often been limited by practical considerations relating to the identification of taxa to species level (Bowie, 2008; 
Buckley et al., 2012; Rate, 2009; Ruscoe et al., 2013; Sinclair et al., 2005; Stringer \& Hitchmough, 2012). Limiting identifications to order or family level almost certainly excludes important species-specific responses to different environmental variables such as predation. Although attempts were made to identify beetles as far as possible to species level in this study, exploratory analyses on some of the more common beetle taxa did not produce significant results, likely due to insufficient sample sizes, so further analysis at this level was not pursued. Nevertheless, it is important to consider species identity when considering the impact of introduced mammals on invertebrates as responses are unlikely to be completely uniform across family groups.

Among ground wêtā only two species were identified with Hemiandrus pallitarsis by far the most frequently encountered. The only other species encountered was Hemiandrus bilobatus with two individuals recorded. Previous records from the Orongorongo Valley reported the presence of Hemiandrus maculifrons (Moeed \& Meads, 1985) however none were identified from the specimens collected. Cave wêtā were not identified to species, however likely belong within the genera Isoplectron, Pleioplectron, and Pachyrhamma (synonymised with Gymnoplectron and Turbottoplectron) all of which have been recorded in the Orongorongo Valley previously (Giribet \& Boyer, 2010; Moeed \& Meads, 1985; Taylor-Smith et al., 2016).

Tree wētā were all Hemeidena crassidens and no other species of tree wētā has been recorded in the Remutaka and Aorangi forest park previously. Species within Hemideina all display female defence mating systems where sexual selection has produced increased male head and jaw size and have broadly comparable niches will little range overlap allowing behaviour to be inferred from other Hemeidena species. Cave wētā in wētā motels were not identified to species and it is not known if the species of cave wētā identified in wētā motels are the same as those identified in pitfalls.

Most of New Zealand invertebrate taxa extinct or threatened due introduced mammalian predators are larger species such as Deinacrida mahoenui (Watts \& Thornburrow, 2009). Fossils of some large extinct beetle species such as Tymbopiptus valeas (23mm) disappear from deposits around the same time that introduced mammal predators arrived in New Zealand (Gibbs, 2009), however these types of observations are sparse and anecdotal. It is likely that the species sampled over this study largely represent species which are resilient to mammal predation due to this mainland location and the long history of mammal predation in the area. 


\subsection{Study limitations}

Although strong negative associations between rats and invertebrate abundance and some negative associations were also found for mice, it should not be expected that similar associations will be found in all environments (Watts et al., 2014). The impact of mammals on invertebrate communities is dependent on a range of environmental variables, the state of the original invertebrate community at the beginning of the study and the strengths and weaknesses of the monitoring methodology. The greatest challenge with understanding the impact of mammals on native invertebrates is the difficulty in establishing historical baselines for the composition and identity of the original invertebrate fauna (Gibbs, 2010; Kuschel \& Worthy, 1996; Watts et al., 2019). It is not known to what extent the current invertebrate fauna of New Zealand forests reflects that of its pre-human state or which taxa are likely to be over/underrepresented. Some research has suggested that the current state of carabid beetle communities today represents only collapsed or diminished assemblages relative to their original diversity (Lövei \& Cartellieri, 2000) but this is extremely difficult, if not impossible, to verify.

Whilst so much of New Zealand's invertebrate fauna remains undescribed and fundamental ecology remains unknown it will always be difficult to assess the relationships within invertebrate communities. The responses of some invertebrate communities such as those on islands and ecosanctuaries sometimes show equivocal or ambiguous results, such as declines after the removal of mammals or declines in certain taxa following mammal removal, possibly due to the return of indigenous predators (Vergara, 2018; Watts et al., 2014). Introduced mammals have disproportionately negative impacts on populations of deep endemic forest birds and other large native fauna (Fea et al., 2021; Innes et al., 2010), it is likely that this is at least partly true for populations of invertebrates due to the disappearance of many large invertebrate species from the mainland (Gibbs, 2009; Giribet \& Boyer, 2010; Kuschel \& Worthy, 1996). However, it seems unlikely that as great a proportion of invertebrates are as vulnerable to extinction due to mammals as invertebrates would have coevolved with avian and reptilian predators. Invertebrate communities are characterised by their strong responses to environmental variables such as resource availability, temperature and humidity which impact invertebrates in a far more direct way than mammal predation (Dornelas \& Daskalova, 2020). Nevertheless, without more detailed information of invertebrate ecology and diversity in New Zealand this will continue to be speculative. 
Whilst rats and mice are omnivorous, taking invertebrates opportunistically or in accordance with the availability of other food sources, indigenous invertebrate predators are likely more efficient and specialised for invertebrate predation (Gibbs, 2009, 2010; Innes et al., 2010; Miller \& Miller, 1995; Wilson et al., 2007). Many native insectivores have disappeared from much of their former range and it is likely that the effect of mammal predators on invertebrates is dependent on whether there are native vertebrate insectivores able to recolonise after mammal eradication. Species such as kiwi (Apteryx), New Zealand robin (Petroica), saddleback (Philesturnus), weka (Gallirallus australis), tuatara (Sphenodon punctatus), skinks (Scincidae), geckos (Diplodactylidae), rifleman (Acanthisitta chloris), Mohua and kaka (Nestor meridionalis) have been largely extirpated from their former ranges and are likely to have had significant impacts on invertebrate populations also (Gibbs, 2010). This may explain why results differ somewhat around the country. In Zealandia ecosanctuary for instance, following the eradication of most mammals beetle abundance was observed to decline, suggesting that there may have been some effect of native predators or possibly an increasing mouse population (Watts et al., 2014). It is also possible that some native invertebrate taxa have benefitted from mammal predation due to the removal of their natural predators, however this is impossible to verify at present.

In addition to changes in the predatory landscape experienced by invertebrates the indirect effects of increased mammal populations may also have altered invertebrate communities. Populations of indigenous birds and reptiles would likely have contributed different nutrient sources in forest environments than the current swathe of introduced herbivorous mammals (Wardle et al., 2001). Large mostly herbivorous bird species, such as Moa (Dinornithiformes), would have likely strongly influenced plant communities and nutrient inputs in the form of dung (Wood et al., 2020). Seabirds such as fairy prions (Pachyptila turtur) and grey faced petrels (Pterodroma gouldi) would have been prevalent in New Zealand forest environments prior to human settlement and would likely have introduced significant nutrient inputs into the system which would have impacted strongly on invertebrate communities (Fukami et al., 2006; Hawke et al., 1998). Indeed, it is speculated that the part of the attractive power of squid bait is due to the preference for marine derived carrion in many of New Zealand's native invertebrates reflecting the evolutionary legacy of seabird derived nutrition (Jones et al., 2012; Stavert, Drayton, et al., 2014; Stavert, Gaskett, et al., 2014).

Pitfall trapping and wētā motels are established methods for studying invertebrate diversity, however they are only ever going to be able to capture a fraction of the overall invertebrate 
diversity in an area, so inferences about the general impact of mammals on the full range of invertebrates are limited. It is likely that the responses of flying and arboreal species will differ significantly from those of surface active and cavity dwelling invertebrates (Gibbs, 1998, 2009). Larvae were similarly not examined in this study and are likely to make up a substantial portion of the prey species of rats, mice and hedgehogs and may where the impacts of mammal predation are most strongly felt (Hendra, 1999; Jones et al., 2005; Nottingham et al., 2019; Russell et al., 2020; Sweetapple \& Nugent, 2007). A further limitation of pitfall trapping was the large number of zero values recorded due to empty pitfalls. Alternative models such as zero-inflation models or family negative binomial models could also be used to account for this however these models were not explored in detail.

Although tracking tunnels are a common and relatively reliable method for estimating mammal abundances in New Zealand, there are limitations to this method and other factors such as resource availability and habitat may influence the recorded index (Brown et al., 1996; Wilmshurst \& Carpenter, 2020). The layout of tracking tunnels is designed principally for rat detection with tunnels placed every $50 \mathrm{~m}$ to reflect the typical home range of forest rats. The effectiveness of tracking tunnels for predicting the abundance and population density of mice and hedgehogs is therefore less well known and may be less reliable. This is complicated further by the tendency of mice to avoid areas frequented by rats, meaning mice may be less likely to visit tunnels already visited by rats although mice do display neophilia (Brown et al., 1996).

\subsection{Implications for management}

This study indicates that populations of introduced mammalian insectivores can impact negatively on the abundance of pitfall trapped invertebrates in New Zealand. Although there are limitations in this study, is also suggests some important management implications. One of the main findings was that not all elements of the invertebrate fauna can be expected to respond equally to mammal control and that the relative abundance of mammal predators present is likely a strong determinant of the overall effect. Density impact functions likely have a role to play in determining the deleterious effects of mammals on invertebrates with some invertebrate communities more vulnerable at higher mammal densities (Norbury et al., 2015). Ground trapped wētā for instance appeared to be strongly negatively impacted by rats, but appeared resilient to mice. By contrast tree wētā only showed a significant negative association with 
mice with particularly for females. This indicates a resilience to rat predation amongst tree wētā whilst being relatively more vulnerable to mice.

The impact of the generalist and omnivorous rat and mouse appeared to be more negative than the specialist insectivore the hedgehog suggesting. This indicates that rats and mice are unlikely to exhibit a clear predator prey relationship with invertebrate populations and likely consume other food sources in accordance with their relative availability (Russell, 2012; Russell et al., 2020; Sweetapple \& Nugent, 2007). This suggests that as with other indigenous fauna there is likely a strong seasonal effect of rats and mice on invertebrate abundance and the possibility that fluctuations in resource availability such as seed production may exacerbate the negative impacts of mammals by increasing the intensity of mammal predation (Norbury et al., 2015; D. J. Wilson et al., 2018).

As with predator control operations designed to protect native birds it is likely important to increase control in years of high resource abundance such as masts to protect indigenous invertebrate communities and dampen fluctuations in mammal predator abundance (Tompkins \& Veltman, 2006). This is likely less important when it comes to hedgehogs which do not seem to respond directly to increases in seed production and are likely more limited by factors such as temperature, humidity and prey abundance (Brockie, 1958; King \& Forsyth, 2021).

Apart from other beetles, hedgehogs did not seem to negatively impact invertebrates with a positive correlation instead being observed between hedgehog index and pitfall trapped invertebrates. It was interesting therefore to note the apparently bottom up regulation of hedgehogs by invertebrates suggesting that hedgehogs were a relatively unimportant driver of invertebrate populations. It is possible that with a longer time lag the negative impacts of hedgehogs could become more apparent. This may be environment specific, however, as hedgehogs did not appear to achieve particularly high densities in this study. Studies from elsewhere have indicated a strong impact and threat of hedgehogs on wētā and other invertebrates (Hamilton, 1999; Jones et al., 2013). In warmer drier conditions where hedgehog populations are likely to be higher, the impacts on invertebrates may be more severe. However, in damp, forested environments the risk hedgehogs pose to invertebrate populations may be minimal.

The lack of evidence of a cyclical predator-prey relationship between rodents and invertebrates may mean that rats and mice represent a greater risk to invertebrate populations as they are more likely to exhaust invertebrate populations (Russell et al., 2020). This is likely to be a 
consideration for isolated invertebrate communities where large spikes in predator populations carry a greater risk of overexploitation. It is therefore important to consider habitat size in invertebrate conservation as the amount of refugia available to invertebrates will influence their likelihood of local extinction in response to peaks in mammal populations (Lövei \& Cartellieri, 2000; Norbury et al., 2015; Walker et al., 2019).

Despite the risk of overexploitation, invertebrates typically have short generation times and produce many offspring, traits which allow them to respond rapidly to environmental fluctuations (Dornelas \& Daskalova, 2020), but also likely makes them more resilient to mammal predation. Many of the taxa thought to be most vulnerable to mammal predation, such as large carabid beetles and wētā do appear to be capable of reproducing all year round potentially mitigating against the effects of seasonal peaks in mammal abundance (Cartellieri \& Lövei, 2003; Gwynne, 2004; Hutchison, 2001, 2007; Lövei \& Cartellieri, 2000; Lovei \& Sunderland, 1996; Philip \& Burgess, 2008). Whilst this indicates that invertebrates generally are more robust to overexploitation by introduced mammals than vertebrate taxa, it should be noted that many New Zealand invertebrates do show particularly long generation times and relatively low fecundity.

Conditional $\mathrm{R}^{2}$ values were also relatively low suggesting that a significant proportion of the variation in invertebrate catch and occupancy was likely due to environmental variables not included in the models. This indicates that direct predation may not be the most important factor affecting invertebrate populations. There are many potential pathways by which mammal populations may be able to impact on invertebrate communities through broader ecosystem effects and their impacts on other taxa. The availability of nutrient subsidies such as dung, carrion and seed fall probably more strongly limit invertebrate populations and it likely that mammals influence these nutrient flows (Fukami et al., 2006). This is an important, but often overlooked, aspect of the impact of introduced mammals on invertebrate communities and deserves further study, particularly in mainland habitats (Wardle et al., 2001).

Although this study demonstrates that mammals can have deleterious impacts on beetle and wêtā communities it is not the only factor which effects invertebrate conservation (Leather, 2017; Leschen et al., 2012; Lester et al., 2014; Watts et al., 2019; Watts et al., 2014). Ensuring sufficient habitat space, refugia and habitat connectivity are likely important considerations for invertebrate communities and reduce the risk of invertebrate overexploitation by introduced mammals. This is particularly important given the presumed low dispersal abilities of many of 
New Zealand's flightless invertebrate fauna (Hutchison, 2001; Lövei \& Cartellieri, 2000; Lovei \& Sunderland, 1996). Dampening mammal population eruptions is also an important consideration as invertebrates appear to be more likely to be impacted at higher mammal densities. Ideally, if controlling mammals for the sake of improving overall invertebrate community health, then it is important to define exactly which elements of the invertebrate fauna are indicative of community health or line up with conservation goals. Controlling mammals to preserve specific rare or threatened taxa is likely to require more aggressive mammal control strategies focussed on eradication. More modest mammal control may be sufficient to see a general improvement or increase in invertebrate community abundance particularly across large areas of habitat where there is likely greater refuge for invertebrates and asynchrony in mammal populations (King, 2007).

\subsection{Future research}

The analyses conducted in this study were crude in that they focussed on easily measurable metrics of invertebrate communities such as overall catch/occupancy and mean size, however this is not always a suitable measure of other aspects of ecological community structure or function. Although declines in invertebrate catch are highly indicative of a negative effect of mammals on invertebrate populations, metrics relating to overall species diversity and richness may be more informative measures of invertebrate community responses to mammal predation (Watts et al., 2020).

Future progress in understanding the effect of mammal predation on invertebrate communities is likely to be limited without a greater understanding of the basic life histories and ecology of New Zealand invertebrates more generally. Apart from some species of tree and ground wētā, fundamental information relating to the life histories of New Zealand invertebrates is mostly absent (Lester et al., 2014). Although it does appear that mammal populations significantly affect invertebrate communities, the precise implications this has for conservation and broader ecosystem function are difficult to understand without greater species-specific information. Further research is also needed to establish the historical ranges and abundance of invertebrates to establish more consistent baselines for invertebrate communities and help inform conservation goals (Kuschel \& Worthy, 1996; Watts et al., 2019). This is complicated by the lack of historical observations, difficulty in identifying invertebrates from sub-fossils and the likelihood of cryptic extinctions, but is essential for further progress in understanding invertebrate communities in New Zealand. With so little known about the conservation status 
and prevalence of many species it is extremely difficult to accurately assess the threat posed by introduced mammal predators to indigenous invertebrates (Leschen et al., 2012; Stringer \& Hitchmough, 2012; Trewick et al., 2012). Whilst it is thought that the larger, flightless and long-lived invertebrates are the most vulnerable to mammal predation very little is known about smaller less conspicuous species $<10 \mathrm{~mm}$ which are even less well described (Buckley et al., 2012). It is also important to study the response of invertebrate communities to indigenous invertebrate predators such as birds and reptiles which are likely to impact on invertebrate communities. These considerations are particularly pressing given current plans to make New Zealand free of rats, stoats and possums by 2050 . Without a greater understanding of the impacts of indigenous insectivores and the impacts of mammals not included in predator free 2050 , such as mice and hedgehogs, there is the risk of inadvertent losses caused by these species (Kitchin et al., 2017; Linklater \& Steer, 2018; Watts et al., 2014). 


\section{References}

Alley, J. C., Berben, P. H., Dugdale, J. S., Fitzgerald, B. M., Knightbridge, P. I., Meads, M. J., \& Webster, R. A. (2001). Responses of litter-dwelling arthropods and house mice to beech seeding in the Orongorongo Valley, New Zealand. Journal of the Royal Society of New Zealand, 31(2), 425-452.

Angel, A., Wanless, R. M., \& Cooper, J. (2009). Review of impacts of the introduced house mouse on islands in the Southern Ocean: are mice equivalent to rats? Biological Invasions, 11(7), 17431754.

Berndt, L. A., \& Brockerhoff, E. G. (2019). Effects of land cover type on carabid beetles (Coleoptera: Carabidae) of the Canterbury foothills, New Zealand. New Zealand Journal of Forestry Science, 49.

Berndt, L. A., Brockerhoff, E. G., \& Jactel, H. J. (2008). Relevance of exotic pine plantations as a surrogate habitat for ground beetles (Carabidae) where native forest is rare. In Plantation Forests and Biodiversity: Oxymoron or Opportunity? (pp. 247-261). Springer.

Blackwell, G. L. (2000). An investigation of the factors regulating house mouse (Mus musculus) and ship rat (Rattus rattus) population dynamics in forest ecosystems at Lake Waikaremoana, New Zealand Massey University]. Palmerston North, New Zealand.

Bleakley, C., Stringer, I. A. N., Robertson, A., \& Hedderley, D. (2006). Design and use of artificial refuges for monitoring adult tree weta, Hemideina crassidens and H. thoracica. Science \& Technical Publishing, Department of Conservation.

Bowie, M. H. (2008). Ecological restoration of the invertebrate fauna on Quail Island (Ōtamahua). Conserv-Vision: the Next 50 Years. Proceedings of the Conserv-Vision Conference,

Bowie, M. H., Allen, W. J., McCaw, J., \& van Heugten, R. (2014). Factors influencing occupancy of modified artificial refuges for monitoring the range-restricted Banks Peninsula tree weta Hemideina ricta (Anostostomatidae). New Zealand Journal of Ecology, 132-138. 
Bremner, A. G., Barratt, B. I. P., Butcher, C. F., \& Patterson, G. B. (1989). The effects of mammalian predation on invertebrate behaviour in South West Fiordland. New Zealand Entomologist, 12(1), 72-75.

Bremner, A. G., Butcher, C. F., \& Patterson, G. B. (1984). The density of indigenous invertebrates on three islands in Breaksea Sound, Fiordland, in relation to the distribution of introduced mammals. Journal of the Royal Society of New Zealand, 14(4), 379-386.

Brockie, R. E. (1958). The Ecology of the Hedgehog (Erinaceus europaeus L.) in Wellington, New Zealand Victoria University of Wellington].

Broome, K., Brown, D., Brown, K., Murphy, E., Birmingham, C., Golding, C., Corson, P., Cox, A., \& Griffiths, R. (2019). House mice on islands: management and lessons from New Zealand. Island invasives: scaling up to meet the challenge(62), 100.

Brown, K. P., Moller, H., Innes, J. G., \& Alterio, N. (1996). Calibration of tunnel tracking rates to estimate relative abundance of ship rats (Rattus rattus) and mice (Mus musculus) in a New Zealand forest. New Zealand Journal of Ecology, 271-275.

Brown, M. (2013). The Diet and Nutritional Ecology of the Auckland Tree Wètā Hemideina thoracica University of Waikato].

Buckley, T. R., Palma, R. L., Johns, P. M., Gleeson, D. M., Heath, A. C. G., Hitchmough, R. A., \& Stringer, I. A. N. (2012). The conservation status of small or less well known groups of New Zealand terrestrial invertebrates. New Zealand Entomologist, 35(2), 137-143. https://doi.org/10.1080/00779962.2012.686319

Bulgarella, M., Trewick, S. A., Godfrey, A. J. R., Sinclair, B. J., \& Morgan-Richards, M. (2015). Elevational variation in adult body size and growth rate but not in metabolic rate in the tree weta Hemideina crassidens. Journal of insect physiology, 75, 30-38.

Byrom, A. E., Innes, J. G., \& Binny, R. N. (2016). A review of biodiversity outcomes from possumfocused pest control in New Zealand. Wildlife Research, 43(3), 228-253.

Campbell, D. J., Moller, H., Ramsay, G. W., \& Watt, J. C. (1984). Observations on foods of kiore (Rattus exulans) found in husking stations on northern offshore islands of New Zealand. New Zealand Journal of Ecology, 131-138. 
Cardoso, P., \& Leather, S. R. (2019). Predicting a global insect apocalypse. Insect Conservation and Diversity, 12(4), 263-267.

Carpenter, J. K., Monks, J. M., \& O'Donnell, C. F. J. (2016). Developing indices of relative abundance for monitoring cave and ground wētā (Orthoptera) in southern beech forest, New Zealand. New Zealand Journal of Zoology, 43(2), 149-162. https://doi.org/10.1080/03014223.2015.1117500

Cartellieri, M., \& Lövei, G. L. (2003). Seasonal dynamics and reproductive phenology of ground beetles (Coleoptera, Carabidae) in fragments of native forest in the Manawatu, North Island, New Zealand. New Zealand Journal of Zoology, 30(1), 31-42. https://doi.org/10.1080/03014223.2003.9518322

Cary, P. R. L. (1981). The biology of the weta Zealandosandrus gracilis:(Orthoptera: Stenopelmatidae) from the Cass region.

Castro, I., Cunningham, S. J., Gsell, A. C., Jaffe, K., Cabrera, A., \& Liendo, C. (2010). Olfaction in birds: a closer look at the kiwi (Apterygidae). Journal of Avian Biology, 41(3), 213-218. https://doi.org/10.1111/j.1600-048x.2010.05010.x

Chand, R. C., \& Cridge, B. J. (2020). Upscaling Pest Management From Parks to Countries: A New Zealand Case Study. Journal of Integrated Pest Management, 11(1), 1-12. https://doi.org/10.1093/jipm/pmaa006

Chappell, E. M. (2008). Morphology, phylogeography and drumming behaviour of a New Zealand ground weta, Hemiandrus pallitarsis [Masters, Massey University]. http://hdl.handle.net/10179/828

Chappell, E. M., Trewick, S. A., \& Morgan-Richards, M. (2012). Shape and sound reveal genetic cohesion not speciation in the New Zealand orthopteran, Hemiandrus pallitarsis, despite high mitochondrial DNA divergence. Biological Journal of the Linnean Society, 105(1), 169-186. https://doi.org/10.1111/j.1095-8312.2011.01777.x

Chappell, E. M., Webb, D. S., \& Tonkin, J. D. (2014). Notes on sexual size dimorphism, sex ratio and movements of adult ground weta Hemiandrus maculifrons (Walker)(Orthoptera: Anostostomatidae). New Zealand Entomologist, 37(2), 83-92. 
Craddock, P. (1997). The effect of rodent control on invertebrate communities in coastal forest near Auckland [Doctoral disertation, ResearchSpace@ Auckland].

Dent, E. (2016). The impacts of an introduced mammalian predator (Mus musculus) on tree weta (Hemideina trewicki) and skinks (Oligosoma polychroma, Oligosoma infrapunctatum and Oligosoma lineoocellatum) in Cape Sanctuary, Hawkes Bay.

Diamond, J. M. (1990). New Zealand as an archipelago: an international perspective. Ecological restoration of New Zealand islands, 2, 3-8.

Dilks, P., Sjoberg, T., \& Murphy, E. C. (2020). Effectiveness of aerial 1080 for control of mammal pests in the Blue Mountains, New Zealand. New Zealand Journal of Ecology, 44(2), 1-7.

Dornelas, M., \& Daskalova, G. N. (2020). Nuanced changes in insect abundance. Science, 368(6489), 368-369.

Eason, C. (2002). Sodium monofluoroacetate (1080) risk assessment and risk communication. Toxicology, 181, 523-530.

Efford, M. G., Fitzgerald, B. M., Karl, B. J., \& Berben, P. H. (2006). Population dynamics of the ship rat Rattus rattus L. in the Orongorongo Valley, New Zealand. New Zealand Journal of Zoology, 33(4), 273-297.

Elliott, G., \& Kemp, J. (2016). Large-scale pest control in New Zealand beech forests. Ecological Management \& Restoration, 17(3), 200-209.

Farnworth, B., Innes, J. G., Kelly, C., Littler, R., \& Waas, J. R. (2018). Photons and foraging: artificial light at night generates avoidance behaviour in male, but not female, New Zealand weta. Environmental Pollution, 236, 82-90.

Fea, N., Linklater, W., \& Hartley, S. (2021). Responses of New Zealand forest birds to management of introduced mammals. Conservation Biology, 35(1), 35-49.

Fitness, J. L., Morgan-Richards, M., Ball, O.-P., Godfrey, A. J. R., \& Trewick, S. A. (2015). Improved resolution of cave weta diversity (Orthoptera: Rhaphidophoridae): ecological implications for Te Paki, Far North, New Zealand. New Zealand Journal of Zoology, 42(1), 1-16. https://doi.org/10.1080/03014223.2014.983939 
Fitzgerald, B. M., Efford, M. G., \& Karl, B. J. (2004). Breeding of house mice and the mast seeding of southern beeches in the Orongorongo Valley, New Zealand. New Zealand Journal of Zoology, 31(2), 167-184. https://doi.org/10.1080/03014223.2004.9518370

Foster, N. J., Maloney, R. F., Seddon, P. J., Recio, M. R., Khan, M. S. I., \& Van Heezik, Y. (2021). Altitudinal distribution of the entire invasive small mammal guild in the eastern dryland zone of New Zealand's Southern Alps. Biological Invasions. https://doi.org/10.1007/s10530-02102474-y

Foster, S., King, C., Patty, B., \& Miller, S. (2011). Tree-climbing capabilities of Norway and ship rats. New Zealand Journal of Zoology, 38(4), 285-296.

Fukami, T., Wardle, D. A., Bellingham, P. J., Mulder, C. P. H., Towns, D. R., Yeates, G. W., Bonner, K. I., Durrett, M. S., Grant-Hoffman, M. N., \& Williamson, W. M. (2006). Above- and belowground impacts of introduced predators in seabird-dominated island ecosystems. Ecology Letters, 9(12), 1299-1307. https://doi.org/10.1111/j.1461-0248.2006.00983.x

Gibbs, G. W. (1998). Why are some weta (Orthoptera: Stenopelmatidae) vulnerable yet others are common? Journal of Insect Conservation, 2(3-4), 161-166.

Gibbs, G. W. (2009). The end of an 80-million year experiment: a review of evidence describing the impact of introduced rodents on New Zealand's 'mammal-free' invertebrate fauna. Biological Invasions, 11(7), 1587-1593. https://doi.org/10.1007/s10530-008-9408-x

Gibbs, G. W. (2010). Do New Zealand invertebrates reflect the dominance of birds in their evolutionary history? New Zealand Journal of Ecology, 34(1), 152.

Giribet, G., \& Boyer, S. L. (2010). Moas Ark or Goodbye Gondwana: is the origin of New Zealands terrestrial invertebrate fauna ancient, recent, or both? Invertebrate Systematics, 24(1), 1-8. https://doi.org/https://doi.org/10.1071/IS10009

Glen, A. S., Perry, M., Yockney, I., Cave, S., Gormley, A. M., Leckie, C., Dickson, R., Rakete-Stones, W., Rakete-Stones, P., \& Norbury, G. L. (2019). Predator control on farmland for biodiversity conservation. New Zealand Journal of Ecology, 43(1), 1-7.

Gnanasunderam, C., Young, H., Butcher, C. F., \& Hutchins, R. F. N. (1981). Ethyl decanoate as a major component in the defensive secretion of two new zealand aleocharine (staphylinidae) beetles- 
Tramiathaea cornigera (broun) and Thamiaraea fuscicornis (broun). Journal of chemical ecology, 7(1), 197-202.

Griffin, M. J., Morgan-Richards, M., \& Trewick, S. A. (2011). Is the tree weta Hemideina crassidens an obligate herbivore. New Zealand Natural Sciences, 36, 11-19.

Griffin, M. J., Trewick, S. A., Wehi, P. M., \& Morgan-Richards, M. (2011). Exploring the concept of niche convergence in a land without rodents: the case of weta as small mammals. New Zealand Journal of Ecology, 302-307.

Gwynne, D. T. (2002). A secondary copulatory structure in a female insect: a clasp for a nuptial meal? Naturwissenschaften, 89(3), 125-127.

Gwynne, D. T. (2004). Reproductive behavior of ground weta (Orthoptera: Anostostomatidae): drumming behavior, nuptial feeding, post-copulatory guarding and maternal care. Journal of the Kansas Entomological Society, 77(4), 414-428.

Gwynne, D. T. (2005). The secondary copulatory organ in female ground weta (Hemiandrus pallitarsis, Orthoptera: Anostostomatidae): a sexually selected device in females? Biological Journal of the Linnean Society, 85(4), 463-469. https://doi.org/10.1111/j.1095-8312.2005.00510.x

Hamilton, W. J. (1999). Potential threat of hedgehogs to invertebrates with a restricted range, Otago region. Department of Conservation Dunedin.

Hartley, S., \& Fea, N. (2020). Biodiversity responses to possum-conrol in Aorangi and Haurangi Forests. V. U. o. Wellington.

Hawke, D. J. H., R. N., Causer, J. E., \& Ogden, S. (1998). Soil indicators of pre-European seabird breeding in New Zealand at sites identified by predator deposits. Soil Research, 37(1), 103114. https://doi.org/https://doi.org/10.1071/S98050

Hendra, R. (1999). Seasonal abundance patterns and dietary preferences of hedgehogs at Trounson Kauri Park. Department of Conservation Wellington.

Holdaway, R. N. (1989). New Zealand's pre-human avifauna and its vulnerability. New Zealand Journal of Ecology, 11-25.

Holloway, B. A. (2007). Lucanidae (Insecta: Coleoptera). Fauna of New Zealand, 61. 
Holwell, G. I., \& Andrew, N. R. (2015). Protecting the small majority: insect conservation in Australia and New Zealand. Austral Ark, 278.

Huffaker, C. B. (1958). Experimental studies on predation: dispersion factors and predator-prey oscillations. Hilgardia, 27(14), 343-383.

Hutchison, M. A. S. (2001). Habitat use, seasonality and ecology of carabid beetles (Coleoptera: Carabidae) in native forest remnants, North Island, New Zealand [Masters, Massey University]. http://hdl.handle.net/10179/8622

Hutchison, M. A. S. (2007). Seasonality and life histories of two endemic New Zealand carabid beetles (Coleoptera: Carabidae): Mecodema oconnori Broun and Megadromus capito (White). New Zealand Journal of Zoology, 34(1), 79-89.

Innes, J. G., Fitzgerald, N., Binny, R., Byrom, A., Pech, R., Watts, C., Gillies, C., Maitland, M., Campbell-Hunt, C., \& Burns, B. (2019). New Zealand ecosanctuaries: types, attributes and outcomes. Journal of the Royal Society of New Zealand, 49(3), 370-393. https://doi.org/10.1080/03036758.2019.1620297

Innes, J. G., Kelly, C., Fitzgerald, N., Warnock, M., \& Waas, J. (2018). Detection of wild house mice and other small mammals up trees and on the ground in New Zealand native forest. New Zealand Journal of Zoology, 45(3), 227-237. https://doi.org/10.1080/03014223.2018.1461660

Innes, J. G., Kelly, D., Overton, J. M., \& Gillies, C. (2010). Predation and other factors currently limiting New Zealand forest birds. New Zealand Journal of Ecology, 34(1), 86-114. www.jstor.org/stable/24060715

Jones, A. G., Forgie, S. A., Scott, D. J., \& Beggs, J. R. (2012). Generalist dung attraction response in a New Zealand dung beetle that evolved with an absence of mammalian herbivores. Ecological Entomology, 37(2), 124-133. https://doi.org/10.1111/j.1365-2311.2012.01344.x

Jones, C., Moss, K., \& Sanders, M. (2005). Diet of hedgehogs (Erinaceus europaeus) in the upper Waitaki Basin, New Zealand: implications for conservation. New Zealand Journal of Ecology, 29-35. 
Jones, C., \& Norbury, G. (2011). Feeding selectivity of introduced hedgehogs Erinaceus europaeus in a dryland habitat, South Island, New Zealand. Acta Theriologica, 56(1), 45-51. https://doi.org/10.1007/s13364-010-0009-6

Jones, C., Norbury, G., \& Bell, T. (2013). Impacts of introduced European hedgehogs on endemic skinks and weta in tussock grassland. Wildlife Research, 40(1), 36-44.

Kelly, C. D. (2006). Movement patterns and gallery use by the sexually dimorphic Wellington tree weta. New Zealand Journal of Ecology, 273-278.

King, C. M. (2016). How genetics, history and geography limit potential explanations of invasions by house mice Mus musculus in New Zealand. Biological Invasions, 18(6), 1533-1550.

King, C. M., \& Forsyth, D. (2021). The handbook of New Zealand mammals. CSIRO PUBLISHING.

King, C. M., \& Moody, J. E. (1982). The biology of the stoat (Mustela erminea) in the National Parks of New Zealand II. Food habits. New Zealand Journal of Zoology, 9(1), 57-80.

King, P. A. (2007). The effects of rodents on ground dwelling arthropods in the Waitakere Ranges Auckland University of Technology].

Kitchin, J., Barratt, B. I. P., Jarvie, S., Adolph, S. C., Cree, A., \& Cree, A. (2017). Diet of tuatara (Sphenodon punctatus) translocated to Ōrokonui Ecosanctuary in southern New Zealand. New Zealand Journal of Zoology, 44(3), 256-265. https://doi.org/10.1080/03014223.2017.1305977

Klimaszewski, J., Newton, A. F. J., \& Thayer, M. K. (1996). A review of the New Zealand rove beetles (Coleoptera: Staphylinidae). New Zealand Journal of Zoology, 23(2), 143-160.

Klimaszewski, J., \& Watt, J. C. (1997). Coleoptera: family-group review and keys to identification. Fauna of New Zealand, 37.

Kuschel, G., \& Worthy, T. H. (1996). Past distribution of large weevils (Coleoptera: Curculionidae) in the South Island, New Zealand, based on Holocene fossil remains. New Zealand Entomologist, 19(1), 15-22.

Larochelle, A., \& Larivière, M. C. (2001). Carabidae (Insecta: Coleoptera): catalogue. Fauna of New Zealand, 43.

Larochelle, A., \& Larivière, M. C. (2013). Carabidae (Insecta: Coleoptera): synopsis of species, Cicindelinae to Trechinae (in part). Fauna of New Zealand, 69. 
Larochelle, A., \& Larivière, M. C. (2016). Taxonomic Supplement (2001 to 2015) to the Catalogue of New Zealand Carabidae (Insecta: Coleoptera).

Leather, S. R. (2017). "Ecological Armageddon"-more evidence for the drastic decline in insect numbers. Annals of Applied Biology, 172(1), 1-3.

Leschen, R. A. B., Lawrence, J. F., Kuschel, G., Thorpe, S., \& Wang, Q. (2003). Coleoptera genera of New Zealand. New Zealand Entomologist, 26(1), 15-28.

Leschen, R. A. B., Marris, J. W. M., Emberson, R. M., Nunn, J., Hitchmough, R. A., \& Stringer, I. A. N. (2012). The conservation status of New Zealand Coleoptera. New Zealand Entomologist, 35(2), 91-98.

Lester, P. J., Brown, S. D. J., Edwards, E. D., Holwell, G. I., Pawson, S. M., Ward, D. F., \& Watts, C. H. (2014). Critical issues facing New Zealand entomology. New Zealand Entomologist, 37(1), 1-13. https://doi.org/10.1080/00779962.2014.861789

Linklater, W., \& Steer, J. (2018). Predator Free 2050: A flawed conservation policy displaces higher priorities and better, evidence-based alternatives. Conservation Letters, 11(6), e12593.

Lövei, G. L., \& Cartellieri, M. (2000). Ground beetles (Coleopteram Carabidae) in forest fragments of the Manawatu, New Zealand: Collapsed assemblages? Journal of Insect Conservation, 4(4), 239-244. https://doi.org/10.1023/a:1011370806886

Lovei, G. L., \& Sunderland, K. D. (1996). Ecology and behavior of ground beetles (Coleoptera: Carabidae). Annual review of entomology, 41(1), 231-256.

Marris, J. W. M., \& Johnson, P. J. (2010). A revision of the New Zealand click beetle genus Amychus Pascoe 1876 (Coleoptera: Elateridae: Denticollinae): with a description of a new species from the Three Kings Islands. Zootaxa, 2331(1), 35-56.

McGuinness, C. A. (2007). Carabid beetle (Coleoptera: Carabidae) conservation in New Zealand. Journal of Insect Conservation, 11(1), 31-41. https://doi.org/10.1007/s10841-006-9016-y

Miller, C. J., \& Miller, T. K. (1995). Population dynamics and diet of rodents on Rangitoto Island, New Zealand, including the effect of a 1080 poison operation. New Zealand Journal of Ecology, 1927. 
Miskelly, C. M., Tennyson, A. J. D., \& Bishop, C. R. (2018). New locality records for two species of protected weevils, Anagotus fairburni (Brookes, 1932) and Hadramphus stilbocarpae Kuschel, 1971 (Coleoptera: Curculionidae), from southern Fiordland, New Zealand. Tuhinga: Records of the Museum of New Zealand Te Papa Tongarewa, 20.

Moeed, A., \& Meads, M. J. (1983). INVERTEBRATE FAUNA OF FOUR TREE SPECIES IN ORONGORONGO VALLEY, NEW ZEALAND, AS REVEALED BY TRUNK TRAPS. New Zealand Journal of Ecology, 6, 39-53. www.jstor.org/stable/24052727

Moeed, A., \& Meads, M. J. (1985). Seasonality of pitfall trapped invertebrates in three types of native forest, Orongorongo Valley, New Zealand. New Zealand Journal of Zoology, 12(1), 17-53. https://doi.org/10.1080/03014223.1985.10428264

Moeed, A., \& Meads, M. J. (1987). Seasonality and density of litter and humus invertebrates in broadleaf-podocarp and hard beech forests in Orongorongo Valley, New Zealand. New Zealand Journal of Zoology, 14(1), 51-63.

Moller, H. (1985). Tree wetas (Hemideina crassicruris)(Orthoptera: Stenopelmatidae) of Stephens Island, Cook Strait. New Zealand Journal of Zoology, 12(1), 55-69.

Moss, K., \& Sanders, M. (2001). Advances in New Zealand mammalogy 1990-2000: hedgehog. Journal of the Royal Society of New Zealand, 31(1), 31-42.

Murphy, E. C., Robbins, L., Young, J. B., \& Dowding, J. E. (1999). Secondary poisoning of stoats after an aerial 1080 poison operation in Pureora Forest, New Zealand. New Zealand Journal of Ecology, 175-182.

Nakagawa, S., Johnson, P. C. D., \& Schielzeth, H. (2017). The coefficient of determination R 2 and intra-class correlation coefficient from generalized linear mixed-effects models revisited and expanded. Journal of the Royal Society Interface, 14(134), 20170213.

Nboyine, J. A., Boyer, S., Saville, D., Smith, M. J., \& Wratten, S. D. (2016). Ground wētā in vines of the Awatere Valley, Marlborough: biology, density and distribution. New Zealand Journal of Zoology, 43(4), 336-350. https://doi.org/10.1080/03014223.2016.1193548 
Norbury, G. L., Pech, R. P., Byrom, A. E., \& Innes, J. (2015). Density-impact functions for terrestrial vertebrate pests and indigenous biota: guidelines for conservation managers. Biological Conservation, 191, 409-420.

Norbury, G. L., van den Munckhof, M., Neitzel, S., Hutcheon, A., Reardon, J., \& Ludwig, K. (2014). Impacts of invasive house mice on post-release survival of translocated lizards. New Zealand Journal of Ecology, 322-327.

Nottingham, C. M., Glen, A. S., \& Stanley, M. C. (2019). Snacks in the city: the diet of hedgehogs in Auckland urban forest fragments. New Zea. J. Ecol, 43, 3374.

O'Donnell, C. F. J., \& Hoare, J. M. (2012). Quantifying the benefits of long-term integrated pest control for forest bird populations in a New Zealand temperate rainforest. New Zealand Journal of Ecology, 131-140.

Painting, C. J., \& Holwell, G. I. (2014). Observations on the ecology and behaviour of the New Zealand giraffe weevil (Lasiorhynchus barbicornis). New Zealand Journal of Zoology, 41(2), 147-153.

Parkes, J. P. (1975). Some aspects of the biology of the hedgehog (Erinaceus europaeus L.) in the Manawatu, New Zealand. New Zealand Journal of Zoology, 2(4), 463-472.

Parkes, J. P. (2019). Timing aerial baiting for rodent eradications on cool temperate islands: mice on Marion Island. Island invasives: scaling up to meet the challenge(62), 36.

Pech, R., \& Maitland, M. (2016). Conservation of native fauna in highly invaded systems: managing mammalian predators in New Zealand. Restoration Ecology, 24(6), 816-820.

Philip, B. A., \& Burgess, E. P. J. (2008). Observations on the ecology and behaviour of Ctenognathus novaezelandiae (Fairmaire)(Coleoptera: Carabidae). New Zealand Entomologist, 31(1), 41-46.

Rate, S. R. (2009). Does rat control benefit forest invertebrates at Moehau, Coromandel Peninsula? Pub. Team, Department of Conservation.

Rickard, C. G. (1996). Introduced small mammals and invertebrate conservation in a lowland podocarp forest, South Westland, New Zealand

Rufaut, C. G. (1995). A Comparative study of the Wellington tree weta, hemideina crassidens (blanchard, 1851) in the presence and absence of rodents Victoria University of Wellington]. 
Rufaut, C. G., \& Gibbs, G. W. (2003). Response of a Tree Weta Population (Hemideina crassidens) After Eradication of the Polynesian Rat from a New Zealand Island. Restoration Ecology, 11(1), 13-19. https://doi.org/10.1046/j.1526-100x.2003.00058.x

Ruscoe, W. A. (2001). Advances in New Zealand mammalogy 1990-2000: house mouse. Journal of the Royal Society of New Zealand, 31(1), 127-134.

Ruscoe, W. A., Sweetapple, P. J., Perry, M., \& Duncan, R. P. (2013). Effects of Spatially Extensive Control of Invasive Rats on Abundance of Native Invertebrates in Mainland New Zealand Forests. Conservation Biology, 27(1), 74-82. https://doi.org/10.1111/j.15231739.2012.01932.x

Russell, J. C. (2012). Spatio-temporal patterns of introduced mice and invertebrates on Antipodes Island. Polar Biology, 35(8), 1187-1195. https://doi.org/10.1007/s00300-012-1165-8

Russell, J. C., Innes, J. G., Brown, P. H., \& Byrom, A. E. (2015). Predator-free New Zealand: conservation country. BioScience, 65(5), 520-525.

Russell, J. C., Peace, J. E., Houghton, M. J., Bury, S. J., \& Bodey, T. W. (2020). Systematic prey preference by introduced mice exhausts the ecosystem on Antipodes Island. Biological Invasions, 22(4), 1265-1278. https://doi.org/10.1007/s10530-019-02194-4

Russell, J. C., Robins, J. H., \& Fewster, R. M. (2019). Phylogeography of invasive rats in New Zealand. Frontiers in Ecology and Evolution, 7, 48.

Saunders, M. E., Janes, J. K., \& O’Hanlon, J. C. (2020). Moving on from the insect apocalypse narrative: engaging with evidence-based insect conservation. BioScience, 70(1), 80-89.

Seldon, D. S., \& Beggs, J. R. (2010). The effi cacy of baited and live capture pitfall traps in collecting large-bodied forest carabids. New Zealand Entomologist, 33(1), 30-37.

Seldon, D. S., \& Buckley, T. R. (2019). The genus Mecodema Blanchard 1853 (Coleoptera: Carabidae: Broscini) from the North Island, New Zealand. Zootaxa, 4598(1), zootaxa. 4598.4591. 4591zootaxa. 4598.4591 .4591$.

Sinclair, L., McCartney, J., Godfrey, J., Pledger, S., Wakelin, M., \& Sherley, G. (2005). How did invertebrates respond to eradication of rats from Kapiti Island, New Zealand? New Zealand Journal of Zoology, 32(4), 293-315. https://doi.org/10.1080/03014223.2005.9518421 
St Clair, J. J. H. (2011). The impacts of invasive rodents on island invertebrates. Biological Conservation, 144(1), 68-81. https://doi.org/10.1016/j.biocon.2010.10.006

Starling-Windhof, A., Massaro, M., \& Briskie, J. V. (2011). Differential effects of exotic predatorcontrol on nest success of native and introduced birds in New Zealand. Biological Invasions, 13(4), 1021-1028.

Stavert, J. R., Drayton, B. A., Beggs, J. R., \& Gaskett, A. C. (2014). The volatile organic compounds of introduced and native dung and carrion and their role in dung beetle foraging behaviour. Ecological Entomology, 39(5), 556-565.

Stavert, J. R., Gaskett, A. C., Scott, D. J., \& Beggs, J. R. (2014). Dung beetles in an avian-dominated island ecosystem: feeding and trophic ecology. Oecologia, 176(1), 259-271. https://doi.org/10.1007/s00442-014-3001-z

Stilborn, H. (2019). Survival, predation, and behaviour of the Mahoenui giant wētā ('Deinacrida mahoenui': Anostostomatidae: Orthoptera) Victoria University of Wellington].

Stork, N. E. (2018). How many species of insects and other terrestrial arthropods are there on Earth? Annual review of entomology, 63, 31-45.

Stringer, I. A. N., \& Cary, P. R. L. (2001). Postembryonic development and related changes. The biology of wetas, king crickets and their allies, 399-426.

Stringer, I. A. N., \& Hitchmough, R. A. (2012). Assessing the conservation status of New Zealand's native terrestrial invertebrates. New Zealand Entomologist, 35(2), 77-84. https://doi.org/10.1080/00779962.2012.686309

Stringer, I. A. N., Watts, C., Thornburrow, D., Chappell, R., \& Price, R. (2014). Saved from extinction? Establishment and dispersal of Mercury Islands tusked weta, Motuweta isolata, following translocation onto mammal-free islands. Journal of Insect Conservation, 18(2), 203-214.

Sweetapple, P. J., \& Nugent, G. (2007). Ship rat demography and diet following possum control in a mixed podocarp—-hardwood forest. New Zealand Journal of Ecology, 186-201.

Taylor-Smith, B. 1., Trewick, S. A., \& Morgan-Richards, M. (2016). Three new ground wētā species and a redescription of Hemiandrus maculifrons. New Zealand Journal of Zoology, 43(4), $363-$ 383. https://doi.org/10.1080/03014223.2016.1205109 
Tompkins, D. M., Byrom, A. E., \& Pech, R. P. (2013). Predicted responses of invasive mammal communities to climate-related changes in mast frequency in forest ecosystems. Ecological Applications, 23(5), 1075-1085. https://doi.org/10.1890/12-0915.1

Tompkins, D. M., \& Veltman, C. J. (2006). Unexpected consequences of vertebrate pest control: predictions from a four-species community model. Ecological Applications, 16(3), 1050-1061.

Trewick, S. A. (2021). A new species of large Hemiandrus ground wētā (Orthoptera: Anostostomatidae) from North Island, New Zealand. Zootaxa, 4942(2), 207-218.

Trewick, S. A., \& Morgan-Richards, M. (2000). Artificial weta roosts: A technique for ecological study and population monitoring of Tree Weta (Hemideina) and other invertebrates. New Zealand Journal of Ecology, 201-208.

Trewick, S. A., Morris, S. J., Johns, P. M., Hitchmough, R. A., \& Stringer, I. A. N. (2012). The conservation status of New Zealand Orthoptera. New Zealand Entomologist, 35(2), 131-136. https://doi.org/10.1080/00779962.2012.686318

Trewick, S. A., Taylor-Smith, B., \& Morgan-Richards, M. (2020). Ecology and systematics of the wine wētā and allied species, with description of four new Hemiandrus species. New Zealand Journal of Zoology, 1-34.

Van Aarde, R. J., Ferreira, S. M., \& Wassenaar, T. D. (2004). Do feral house mice have an impact on invertebrate communities on sub-Antarctic Marion Island? Austral Ecology, 29(2), 215-224. https://doi.org/10.1111/j.1442-9993.2004.01341.x

Van Wyngaarden, F. (1995). The ecology of the Tekapo ground wētà (Hemiandrus new sp., Orthoptera: Anostostomatidae) and recommendations for the conservation of a threatened close relative.

Vergara, O. E. (2018). Macroinvertebrate community responses to mammal control - Evidence for topdown trophic effects Victoria University of Wellington].

Vergara, O. E., Nelson, N., \& Hartley, S. (2020). The effects of squid-baiting pitfall traps for sampling wētā (Orthoptera) and other ground-dwelling forest invertebrates. New Zealand Entomologist, $1-9$.

Walker, K. J. (2003). Recovery plans for Powelliphanta land snails. Threatened Species Recovery Plan, 49, 208. 
Walker, S., Kemp, J. R., Elliott, G. P., Mosen, C. C., \& Innes, J. G. (2019). Spatial patterns and drivers of invasive rodent dynamics in New Zealand forests. Biological Invasions, 21(5), 1627-1642. https://doi.org/10.1007/s10530-019-01922-0

Warburton, B., \& Livingstone, P. (2015). Managing and eradicating wildlife tuberculosis in New Zealand. New Zealand Veterinary Journal, 63(sup1), 77-88.

Ward, D., \& Larivière, M. C. (2004). Terrestrial invertebrate surveys and rapid biodiversity assessment in New Zealand: lessons from Australia. New Zealand Journal of Ecology, 28(1), 151-159. www.jstor.org/stable/24058222

Wardle, D. A., Barker, G. M., Yeates, G. W., Bonner, K. I., \& Ghani, A. (2001). Introduced browsing mammals in New Zealand natural forests: aboveground and belowground consequences. Ecological Monographs, 71(4), 587-614.

Watt, J. C. (1984). A review of some New Zealand Scarabaeidae (Coleoptera). New Zealand Entomologist, 8(1), 4-24.

Watt, J. C. (1992). Tenebrionidae (Insecta: Coleoptera): catalogue of types and keys to taxa. Fauna of New Zealand, 26.

Watts, C. H., Armstrong, D. P., Innes, J. G., \& Thornburrow, D. (2011). Dramatic increases in weta (Orthoptera) following mammal eradication on Maungatautari-evidence from pitfalls and tracking tunnels. New Zealand Journal of Ecology, 261-272.

Watts, C. H., Innes, J. G., Cave, V., Thornburrow, D., \& Thorpe, S. (2020). Beetle and wētā community responses to mammal eradication on Maungatautari, Waikato, New Zealand. New Zealand Journal of Zoology, 1-19. https://doi.org/10.1080/03014223.2020.1760898

Watts, C. H., Marra, M. J., Green, C. J., Hunt, L. A., \& Thornburrow, D. (2019). Comparing fossil and extant beetles in central North Island forests, New Zealand. Journal of the Royal Society of New Zealand, 49(4), 474-493. https://doi.org/10.1080/03036758.2019.1597380

Watts, C. H., Stringer, I. A. N., Innes, J. G., \& Monks, J. M. (2017). Evaluating tree wētā (Orthoptera: Anostostomatidae: Hemideina species) as bioindicators for New Zealand national biodiversity monitoring. Journal of Insect Conservation, 21(4), 583-598. https://doi.org/10.1007/s10841017-9997-8 
Watts, C. H., \& Thornburrow, D. (2009). Where have all the weta gone? Results after two decades of transferring a threatened New Zealand giant weta, Deinacrida mahoenui. Journal of Insect Conservation, 13(3), 287-295. https://doi.org/10.1007/s10841-008-9170-5

Watts, C. H., Thornburrow, D., Cave, V., \& Innes, J. G. (2014). Beetle community changes following pest mammal control at two biodiversity sanctuaries in Wellington, New Zealand. Journal of the Royal Society of New Zealand, 44(2-3), 61-87. https://doi.org/10.1080/03036758.2013.875478

Wehi, P. M., Jorgensen, M., \& Morgan-Richards, M. (2013). Sex-and season-dependent behaviour in a flightless insect, the Auckland tree weta (Hemideina thoracica). New Zealand Journal of Ecology, 75-83.

Wilmshurst, J. M., \& Carpenter, J. K. (2020). Rodent detection and monitoring for conservation on islands. New Zealand Journal of Ecology, 44(1), 1-9.

Wilson, A. D. M., \& Kelly, C. D. (2019). Do alternative reproductive strategies in the Wellington tree weta represent different behavioural types? Ethology, 125(6), 380-391.

Wilson, D., Innes, J., Fitzgerald, N., Bartlam, S., Watts, C., \& Smale, M. (2018). Population dynamics of house mice without mammalian predators and competitors. New Zealand Journal of Ecology, 42(2), 192-203. www.jstor.org/stable/26538110

Wilson, D. J., Innes, J. G., Fitzgerald, N. B., Bartlam, S., Watts, C. H., \& Smale, M. C. (2018). Population dynamics of house mice without mammalian predators and competitors. New Zealand Journal of Ecology, 42(2), 192-203. www.jstor.org/stable/26538110

Wilson, D. J., Wright, E. F. C., C. D., \& Ruscoe, W. A. (2007). Neighbourhood analyses of tree seed predation by introduced rodents in a New Zealand temperate rainforest. Ecography, 30(1), 105119.

Winks, C. J., Fowler, S. V., \& Ramsay, G. W. (1998). Captive rearing of the Middle Island tusked weta. Landcare Research Contract Report, to Department of Conservation, Wellington (unpub.).

Wood, J. R., Richardson, S. J., McGlone, M. S., \& Wilmshurst, J. M. (2020). The diets of moa (Aves: Dinornithiformes). New Zealand Journal of Ecology, 44(1), 1-21. 
6 Appendix 
Table 6.1 Total pitfall trapped wētā catch in the Aorangi and Remutaka forests including specimens not used for statistical analyses, Nov 2012 - Nov 2019.

\begin{tabular}{|c|c|c|c|}
\hline & Aorangi & Remutaka & Total \\
\hline $\begin{array}{l}\text { Cave wèta } \\
\text { Rhaphidophoridae) }\end{array} \quad$ (Family: & 242 & 322 & 564 \\
\hline Ground wètā (Hemiandrus spp) & 1162 & 178 & 1240 \\
\hline
\end{tabular}

Table 6.2 Coleoptera species list in the Aorangi and Remutaka forests including specimens no used for statistical analyses, Nov 2012 - Nov 2019.

\begin{tabular}{|c|c|c|c|}
\hline Taxonomic grouping & Aorangi & Remutaka & Total \\
\hline Carabidae (Ground beetles) & 749 & 921 & 1664 \\
\hline Ctenognathus adamsi & 216 & 204 & 420 \\
\hline Ctenognathus bidens & 164 & 548 & 712 \\
\hline Demetrida nastula & 17 & 4 & 21 \\
\hline Holcaspis hispida & 27 & 4 & 31 \\
\hline Holcaspis oedicnema & 32 & 18 & 50 \\
\hline Mecodema longicolle & 3 & 14 & 17 \\
\hline Mecodema simplex & 16 & 36 & 52 \\
\hline Mecodema sp3 & 8 & 0 & 8 \\
\hline Megadromus capito & 101 & 2 & 103 \\
\hline Megadromus vigil & 12 & 58 & 70 \\
\hline Plocamostethus planiusculus & 6 & 14 & 20 \\
\hline Psegmatopterus spl & 2 & 0 & 2 \\
\hline $\operatorname{sp} 9$ & 1 & 0 & 1 \\
\hline sp16 & 142 & 19 & 161 \\
\hline$S p A I$ & 2 & 0 & 2 \\
\hline Chrysomelidae (Leaf Beetles) & 2 & $\mathbf{0}$ & 2 \\
\hline Eucolaspis spl & 2 & 0 & 2 \\
\hline Curculionidae (Weevils) & 38 & 27 & 65 \\
\hline Bradypatae spl & 3 & 1 & 4 \\
\hline Cossoninae spl & 5 & 0 & 5 \\
\hline Cryptorhynchinae spl & 6 & 2 & 8 \\
\hline Curculionidae spC & 2 & 3 & 5 \\
\hline Curculionidae spF & 1 & 0 & 1 \\
\hline Eugnomini spl & 4 & 0 & 4 \\
\hline Epitimetes spl & 1 & 1 & 2 \\
\hline Epitimetes sp2 & 2 & 0 & 2 \\
\hline Geochus spl & 2 & 1 & 3 \\
\hline Lasiorhynchus barbicornis & 0 & 1 & 1 \\
\hline Microcryptorhynchus spl & 0 & 7 & 7 \\
\hline Nestrius spl & 1 & 0 & 1 \\
\hline Phrynixini spl & 9 & 10 & 19 \\
\hline Psepholax spl & 2 & 0 & 2 \\
\hline Scolopterus aеquиs & 0 & 1 & 1 \\
\hline Elateridae (Click beetles) & 53 & 30 & 83 \\
\hline Elateridae sp2 & 15 & 0 & 15 \\
\hline Elateridae sp3 & 21 & 19 & 40 \\
\hline Elateridae sp4 & 10 & 3 & 13 \\
\hline Elateridae sp5 & 3 & 7 & 10 \\
\hline Elateridae sp6 & 4 & 1 & 5 \\
\hline
\end{tabular}


Lucanidae (Stag beetles)

Geodorchus novaezelandia

Paralissotes reticulus

Pselaphinae (Ant like rove beetles)

Eupines sp1

Eupines sp2

Pselaphinae sp4

Pselaphinae sp5

Scarabaeidae (Dung beetles)

Saphobius spp

Sericospilus sp1

Odontia sp1

Odontia sp3

Odontia sp4

\section{Staphylinidae (Rove beetles)}

Creophilus sp1

Scaphidiinae sp1

Scydmaeninae spl

Staphylinidae spl

Staphylinidae sp2

Staphylinidae sp3

Staphylinidae sp4

Staphylinidae sp7

Tachyporidae spl

Tenebrionidae (Darkling beetles)

Brouniphylax spl

Mimopeus sp

Mitua tuberculicostata

Kaszabadelium aucklandicum

\section{Other}

Alticini spl

Anthicidae sp1

Anthicidae sp5

Anthicini sp2

Anthicini sp5

Anthribidae spl

Byrrhidae sp 1

Chelagyrtodes crowsoni

Cholevinae spl

Cicinidelidae $s p$

Ciidae spl

Coccinellidae spl

Corticariinae sp1

Corticariinae sp2

Cotes sp1

Cotes sp2

Cryptodacne sp1

Cryptophagidae spl

Cyloma sp1

Derodontidae spl

Enicmus spl

Epistranus spl

Eucnemidae spl

Hexatricha pulverulenta

\begin{tabular}{|c|c|c|}
\hline 6 & 0 & 6 \\
\hline 5 & 0 & 5 \\
\hline 1 & 0 & 1 \\
\hline 21 & 4 & 25 \\
\hline 0 & 1 & 1 \\
\hline 2 & 0 & 2 \\
\hline 18 & 1 & 19 \\
\hline 1 & 2 & 3 \\
\hline 1305 & 1050 & 2355 \\
\hline 1301 & 1048 & 2349 \\
\hline 1 & 1 & 2 \\
\hline 2 & 0 & 2 \\
\hline 0 & 1 & 1 \\
\hline 1 & 0 & 1 \\
\hline 292 & 50 & 342 \\
\hline 6 & 0 & 6 \\
\hline 3 & 2 & 5 \\
\hline 3 & 1 & 4 \\
\hline 162 & 13 & 175 \\
\hline 89 & 13 & 102 \\
\hline 24 & 8 & 32 \\
\hline 0 & 1 & 1 \\
\hline 5 & 0 & 5 \\
\hline 0 & 12 & 12 \\
\hline 14 & 1 & 15 \\
\hline 3 & 0 & 3 \\
\hline 5 & 0 & 5 \\
\hline 4 & 0 & 4 \\
\hline 2 & 1 & 3 \\
\hline 581 & 116 & 697 \\
\hline 3 & 0 & 3 \\
\hline 1 & 0 & 1 \\
\hline 3 & 0 & 3 \\
\hline 1 & 0 & 1 \\
\hline 3 & 1 & 4 \\
\hline 1 & 0 & 1 \\
\hline 0 & 2 & 2 \\
\hline 4 & 0 & 4 \\
\hline 12 & 20 & 32 \\
\hline 0 & 1 & 1 \\
\hline 1 & 1 & 2 \\
\hline 0 & 1 & 1 \\
\hline 4 & 2 & 6 \\
\hline 3 & 0 & 3 \\
\hline 2 & 0 & 2 \\
\hline 1 & 0 & 1 \\
\hline 1 & 1 & 2 \\
\hline 2 & 4 & 6 \\
\hline 23 & 17 & 40 \\
\hline 5 & 3 & 8 \\
\hline 5 & 1 & 6 \\
\hline 1 & 0 & 1 \\
\hline 7 & 0 & 7 \\
\hline 1 & 0 & 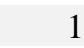 \\
\hline
\end{tabular}


Hisparonia hystrix

Histeridae spl

Histeridae sp3

Holopsis spl

Hydropilidae spl

Hylobia spl

Isocolon spl

Lamiinae spl

Leiodinae spl

Lithostygnus spl

Lyperocharis sp1

Mordellidae spl

Nitidulidae sp1

Nosodendron spl

Notocoxelus spl

Notoptenidium lawsoni

Nototriphyllus sp1

Oedemeridae spl

Parnida agrestis

Picrotus thoracicus

Prionoplus reticularis

Pristoderus bakewelli

Pristoderus sp2

Pristoderus sp3

Ptilodactylidae sp1

Ptininae spl

Pycnomerus spl

Rentoniidae spl

Sapintus spl

Scirtidae sp1

Scirtidae sp2

Scirtidae sp3

Scolytocis novaezelandiae

Sericoderus spl

Sp $A A A$

Sp $A A B$

Sp $A A C$

Sp AJ

$S p A L$

Sp AM

Sp $A N$

$S p C$

$S p G$

SpI

Other spl

Syrphetodes marginatus

Thalycrodes australis

Typhaea spl

Zeanecrophilus thayerae

\begin{tabular}{|c|c|c|}
\hline 2 & 0 & 2 \\
\hline 6 & 3 & 9 \\
\hline 1 & 0 & 1 \\
\hline 3 & 0 & 3 \\
\hline 0 & 4 & 4 \\
\hline 5 & 1 & 6 \\
\hline 1 & 1 & 2 \\
\hline 2 & 0 & 2 \\
\hline 2 & 0 & 2 \\
\hline 6 & 0 & 6 \\
\hline 2 & 1 & 3 \\
\hline 1 & 0 & 1 \\
\hline 1 & 0 & 1 \\
\hline 1 & 0 & 1 \\
\hline 3 & 0 & 3 \\
\hline 5 & 0 & 5 \\
\hline 67 & 4 & 71 \\
\hline 1 & 0 & 1 \\
\hline 1 & 3 & 4 \\
\hline 0 & 1 & 1 \\
\hline 1 & 0 & 1 \\
\hline 10 & 7 & 17 \\
\hline 5 & 2 & 7 \\
\hline 2 & 4 & 6 \\
\hline 0 & 2 & 2 \\
\hline 3 & 0 & 3 \\
\hline 2 & 0 & 2 \\
\hline 3 & 3 & 6 \\
\hline 1 & 0 & 1 \\
\hline 11 & 6 & 17 \\
\hline 5 & 1 & 6 \\
\hline 2 & 0 & 2 \\
\hline 1 & 1 & 2 \\
\hline 17 & 1 & 18 \\
\hline 1 & 4 & 5 \\
\hline 0 & 5 & 5 \\
\hline 1 & 2 & 3 \\
\hline 1 & 0 & 1 \\
\hline 3 & 0 & 3 \\
\hline 12 & 0 & 12 \\
\hline 2 & 0 & 2 \\
\hline 1 & 0 & 1 \\
\hline 3 & 0 & 3 \\
\hline 1 & 0 & 1 \\
\hline 0 & 1 & 1 \\
\hline 3 & 2 & 5 \\
\hline 291 & 0 & 291 \\
\hline 3 & 0 & 3 \\
\hline 2 & 3 & 5 \\
\hline
\end{tabular}


Table 6.3 LMER model and ANOVA type 3 estimates ( $\operatorname{Pr}(>$ Chisq)) for the effect on beetle size for all families of an increase in mammal tracking from 0 to 1 within the current and previous (T1) seasons, while controlling for Season and squid bait (effects not shown). Random effects were site nested within forest. Each row is a model with a different beetle family as the response variable and the mammal index of each species as additive predictor variables. $* \mathrm{P}<0.05, * *=\mathrm{P}<0.001, * * *=\mathrm{P}<0.001$. Arrows indicate the direction of results deemed statistically significant at the $\mathrm{P}<0.01$ level.

\begin{tabular}{|c|c|c|c|c|c|c|c|c|c|c|c|c|c|c|c|}
\hline \multirow[t]{2}{*}{ Size } & \multicolumn{4}{|l|}{ Rats } & \multicolumn{4}{|l|}{ Mice } & \multicolumn{7}{|c|}{ Hedgehog } \\
\hline & $\beta(\mathbf{m m})$ & SE & t-value & $\operatorname{Pr}(>$ Chisq $)$ & $\beta(\mathbf{m m})$ & SE & t-value & $\operatorname{Pr}(>$ Chisq) & $\beta(\mathbf{m m})$ & SE & t-value & $\operatorname{Pr}(>$ Chisq $)$ & Marginal $\mathbf{R}^{2}$ & Conditional $\mathbf{R}^{2}$ & Sample size \\
\hline Carabidae & 0.2 & 0.5 & 0.5 & 0.648 & -0.5 & 1.1 & -0.4 & 0.658 & $\uparrow 3.9$ & 0.9 & 4.1 & $<0.001 * * *$ & 0.04 & 0.13 & 1310 \\
\hline Chysomelidae & NA & NA & NA & NA & NA & NA & NA & NA & NA & NA & NA & NA & NA & NA & 0 \\
\hline Curculionidae & -4.9 & 4.4 & -1.1 & 0.256 & -5.7 & 12.3 & -0.4 & 0.644 & -0.7 & 8.0 & -0.1 & 0.931 & 0.09 & 017 & 50 \\
\hline Elateridae & -0.5 & 1.6 & -0.3 & 0.775 & -1.2 & 2.0 & -0.6 & 0.538 & -1.2 & 3.6 & -0.3 & 0.733 & 0.00 & 0.74 & 66 \\
\hline Lucanidae & NA & NA & NA & NA & NA & NA & NA & NA & NA & NA & NA & NA & NA & NA & 3 \\
\hline Pselaphinae & 1.4 & 0.8 & 1.7 & 0.089 & -3.5 & 8.5 & -0.4 & 0.682 & $\downarrow-7.9$ & 1.9 & -1.1 & $<0.001 * * *$ & 0.33 & 0.96 & 23 \\
\hline Scarabaeidae & 0.1 & 0.1 & 2.0 & $0.045^{*}$ & -0.1 & 0.1 & -0.6 & 0.520 & -0.1 & 0.1 & -1.0 & 0.341 & 0.01 & 0.04 & 1811 \\
\hline Staphylinidae & 2.1 & 1.1 & 1.9 & 0.056 & 0.1 & 1.2 & 0.1 & 0.950 & 1.3 & 2.9 & 0.4 & 0.665 & 0.13 & 0.29 & 271 \\
\hline Tenbrionidae & 14.1 & 5.9 & 2.4 & $0.016^{*}$ & -14.3 & 10.6 & -1.3 & 0.178 & 12.8 & 19.7 & 0.7 & 0.515 & 0.25 & 0.90 & 13 \\
\hline Other beetles & $\uparrow 1.5$ & 0.6 & 2.6 & $0.009 * *$ & -0.2 & 0.7 & -0.2 & 0.830 & -0.1 & 1.3 & -0.0 & 0.967 & 0.06 & 0.17 & 416 \\
\hline \multirow[t]{2}{*}{ Size T-1 } & \multicolumn{4}{|l|}{ Rats } & \multicolumn{4}{|l|}{ Mice } & \multicolumn{7}{|c|}{ Hedgehogs } \\
\hline & $\beta(\mathbf{m m})$ & SE & t-value & $\operatorname{Pr}(>$ Chisq) & $\beta(\mathbf{m m})$ & SE & t-value & $\operatorname{Pr}(>$ Chisq $)$ & $\beta(\mathbf{m m})$ & SE & t-value & $\operatorname{Pr}(>$ Chisq) & Marginal $\mathbf{R}^{2}$ & Conditional $\mathbf{R}^{2}$ & Sample size \\
\hline Carabidae & -1.4 & 0.6 & -2.3 & $0.023^{*}$ & -1.5 & 1.1 & -1.5 & 0.313 & -1.8 & 1.5 & -1.2 & 0.241 & 0.04 & 0.11 & 1158 \\
\hline Chysomelidae & NA & NA & NA & NA & NA & NA & NA & NA & NA & NA & NA & NA & NA & NA & 0 \\
\hline Curculionidae & -5.4 & 4.0 & -1.4 & 0.164 & 5.4 & 22.0 & 0.2 & 0.806 & 6.9 & 14.5 & 0.5 & 0.634 & 0.10 & 0.20 & 47 \\
\hline Elateridae & -3.0 & 1.5 & -2.1 & $0.039^{*}$ & -0.8 & 1.4 & -0.6 & 0.555 & 0.3 & 1.7 & 0.1 & 0.882 & 0.00 & 0.74 & 58 \\
\hline Lucanidae & NA & NA & NA & NA & NA & NA & NA & NA & NA & NA & NA & NA & NA & NA & 3 \\
\hline Pselaphinae & -0.3 & 0.8 & -0.4 & 0.684 & 23.6 & 4.7 & 5.0 & $<0.001 * * *$ & -1.2 & 3.1 & -0.4 & 0.712 & 0.73 & 0.78 & 23 \\
\hline Scarabaeidae & -0.1 & 0.1 & -1.5 & 0.145 & $\uparrow-0.3$ & 0.1 & -3.2 & $0.002 * *$ & $\downarrow-0.7$ & 0.1 & -4.7 & $<0.001 * * *$ & 0.02 & 0.05 & 1794 \\
\hline Staphylinidae & -0.9 & 1.2 & -0.7 & 0.465 & 0.4 & 1.2 & 0.3 & 0.769 & -1.4 & 2.8 & -0.5 & 0.622 & 0.12 & 0.27 & 254 \\
\hline Tenebrionidae & NA & NA & NA & NA & NA & NA & NA & NA & NA & NA & NA & NA & NA & NA & 0 \\
\hline Other beetles & 1.4 & 0.7 & 2.1 & $0.037 *$ & 1.5 & 1.2 & 1.3 & 0.204 & 3.5 & 1.8 & 1.9 & 0.054 & 0.06 & 0.20 & 382 \\
\hline
\end{tabular}


Table 6.4 GLMM model estimates for the effect on beetle catch of an increase in mammal index from 0 to 1 in the current and previous (T-1) season, while controlling for season and squid bait. Random effects were site nested within forest. Sample size was 1936 pitfalls in the T-0 model and 1704 in the T-1 model. Number of individuals caught is the same as for corresponding LMER models shown in table 6.3. Each row is a model with a different beetle family as the response variable and the mammal index of each species as additive predictor variables. $* \mathrm{P}<0.05, * *=\mathrm{P}<0.001$, $* * *=\mathrm{P}<0.001$. Arrows indicate the direction of results deemed statistically significant at the $\mathrm{P}<0.01$ level.

\begin{tabular}{|c|c|c|c|c|c|c|c|c|c|c|c|c|c|c|c|c|c|}
\hline \multirow[t]{2}{*}{ Abundance } & \multicolumn{5}{|l|}{ Rats } & \multicolumn{5}{|l|}{ Mice } & \multicolumn{7}{|c|}{ Hedgehog } \\
\hline & $\boldsymbol{\beta}$ & $\begin{array}{l}\text { Estimate } \\
(\%)\end{array}$ & SE & Z-value & $\operatorname{Pr}(>$ Chisq) & $\boldsymbol{\beta}$ & $\begin{array}{l}\text { Estimate } \\
(\%)\end{array}$ & SE & Z-value & $\operatorname{Pr}(>$ Chisq $)$ & $\boldsymbol{\beta}$ & $\begin{array}{l}\text { Estimate } \\
(\%)\end{array}$ & SE & Z-value & $\operatorname{Pr}(>$ Chisq $)$ & $\begin{array}{l}\text { Marginal } \\
\mathbf{R}^{2} \\
\end{array}$ & $\begin{array}{l}\text { Conditional } \\
\mathbf{R}^{2} \\
\end{array}$ \\
\hline Carabidae & $\downarrow-1.00$ & -63.1 & 0.36 & $\begin{array}{l}-9.04 \\
\end{array}$ & $<0.001 * * *$ & $\begin{array}{l}-0.89 \\
\end{array}$ & -58.8 & 0.22 & -4.05 & $<0.001 * * *$ & $\begin{array}{c}1.22 \\
\end{array}$ & 236.0 & 0.19 & 6.41 & $<0.001 * * *$ & 0.07 & 0.26 \\
\hline Chysomelidae & -3.65 & -97.4 & 4.72 & -0.77 & 0.440 & 4.48 & 8750.0 & 2.66 & 1.68 & 0.092 & 4.44 & 8352.1 & 6.68 & 0.66 & 0.507 & 0.00 & 0.00 \\
\hline Curculionidae & -0.65 & -47.6 & 0.65 & -1.00 & 0.318 & -2.35 & -90.4 & 1.53 & -1.53 & 0.126 & -2.10 & -87.3 & 1.26 & -1.64 & 0.101 & 0.00 & 0.00 \\
\hline Elateridae & 0.04 & 4.49 & 0.49 & 0.09 & 0.928 & -0.90 & -59.2 & 0.96 & -0.93 & 0.351 & -1.74 & -82.4 & 1.24 & -1.40 & 0.161 & 0.00 & 0.00 \\
\hline Lucanidae & -5.66 & -99.7 & 5.04 & -1.12 & 0.261 & 7.00 & 110444.1 & 7.73 & 0.91 & 0.365 & 14.50 & $\begin{array}{c}19827582 \\
6\end{array}$ & 17.09 & 0.85 & 0.396 & 0.99 & 1.00 \\
\hline Pselaphinae & -1.36 & -74.5 & 1.00 & -1.36 & 0.173 & $\downarrow-15.64$ & -100 & 5.66 & -2 & $-0.006 * *$ & $\downarrow-0.65$ & -47.7 & 2.00 & -0.33 & $0.006 * *$ & 0.00 & 0.00 \\
\hline Scarabaeidae & $\downarrow-0.59$ & -44.4 & 0.08 & -7.28 & $<0.001 * * *$ & $\downarrow-0.52$ & -40.6 & 0.13 & -4.03 & $<0.001 * * *$ & $\uparrow 0.97$ & 164.1 & 0.13 & -4.03 & $<0.001 * * *$ & 0.23 & 0.98 \\
\hline Staphylinidae & $\downarrow-1.52$ & -78.0 & 0.27 & -5.68 & $<0.001 * * *$ & 0.12 & 13.3 & 0.34 & 0.37 & 0.714 & -1.15 & -68.3 & 0.59 & -1.96 & $0.050^{*}$ & 0.01 & 0.02 \\
\hline Tenebrionidae & -1.47 & -77.1 & 1.15 & -1.28 & 0.201 & 1.15 & 214.8 & 1.28 & 0.89 & 0.372 & 1.15 & 215.1 & 2.05 & 0.56 & 0.576 & 0.00 & 0.00 \\
\hline Other beetles & $\downarrow-1.47$ & -77.0 & 0.22 & -6.53 & $<0.001 * * *$ & -0.90 & 59.5 & 0.36 & -2.54 & $0.011 *$ & $\downarrow-3.21$ & -96.0 & 0.49 & -6.49 & $<0.001 * * *$ & 0.03 & 0.04 \\
\hline \multirow[t]{2}{*}{ Abundance T-1 } & \multicolumn{5}{|l|}{ Rats } & Mice & & & & & \multicolumn{7}{|c|}{ Hedgehog } \\
\hline & $\boldsymbol{\beta}$ & $\begin{array}{l}\text { Estimate } \\
(\%)\end{array}$ & SE & $Z$-value & $\operatorname{Pr}(>$ Chisq $)$ & $\boldsymbol{\beta}$ & $\begin{array}{l}\text { Estimate } \\
(\%)\end{array}$ & SE & Z-value & $\operatorname{Pr}(>$ Chisq $)$ & $\boldsymbol{\beta}$ & $\begin{array}{l}\text { Estimate } \\
(\%)\end{array}$ & SE & $Z$-value & $\operatorname{Pr}(>$ Chisq $)$ & $\begin{array}{l}\text { Marginal } \\
\mathbf{R}^{2}\end{array}$ & $\begin{array}{l}\text { Conditional } \\
\mathbf{R}^{2}\end{array}$ \\
\hline Curculionidae & 0.04 & 3.7 & 0.57 & 0.06 & 0.950 & -4.40 & 8046.7 & 2.41 & -1.83 & 0.068 & -0.59 & -44.6 & 1.57 & -0.38 & 0.707 & 0.00 & 0.00 \\
\hline Elateridae & -0.24 & -21.6 & 0.52 & -0.47 & 0.639 & $\uparrow 2.04$ & 669.5 & 0.79 & 2.59 & $0.009 * *$ & $\downarrow 4.45$ & 8501.3 & 1.00 & 4.46 & $<0.001 * * *$ & 0.00 & 0.01 \\
\hline Lucanidae & -22.28 & -100 & 12.00 & -1.86 & 0.063 & 4.21 & 6662.7 & 6.95 & 0.61 & 0.544 & -921.7 & $\infty$ & $1.33 \times 10^{7}$ & 0.00 & 1.00 & 1 & 1 \\
\hline Pselaphinae & -0.37 & -30.9 & 0.93 & -0.40 & 0.691 & -8.85 & -100 & 3.92 & -2.26 & $0.024 *$ & -2.96 & -94.8 & 2.82 & -1.05 & 0.293 & 0.00 & 0.00 \\
\hline Scarabaeidae & $\downarrow-1.38$ & -74.8 & 0.10 & -14.39 & $<0.001 * * *$ & -0.22 & -20.1 & 0.14 & -1.64 & 0.102 & -0.55 & -42.4 & 0.24 & -2.32 & $0.021^{*}$ & 0.22 & 0.98 \\
\hline Staphylinidae & -0.69 & -49.9 & 0.29 & -2.42 & $0.016^{*}$ & -0.00 & 0.3 & 0.37 & -0.01 & 0.993 & -0.91 & -59.7 & 0.89 & -1.02 & 0.306 & 0.03 & 0.07 \\
\hline Tenebrionidae & -3.51 & -97.0 & 1.65 & -2.12 & $0.034 *$ & 2.45 & 3234.5 & 1.51 & 1.62 & 0.106 & 3.14 & 2207.2 & 2.67 & 1.18 & 0.239 & 0.00 & 0.00 \\
\hline Other beetles & $\downarrow-1.72$ & -82.1 & 0.24 & -7.10 & $<0.001 * * *$ & -1.07 & -65.6 & 0.45 & -2.35 & $0.019^{*}$ & -1.20 & -70.0 & 0.64 & -1.89 & 0.059 & 0.03 & 0.03 \\
\hline
\end{tabular}


Table 6.5 Correlation matrix for mammal tracking index calculated for site and season $(n=108)$.

\section{Rat index Mouse index Hedgehog index}

\begin{tabular}{lccc}
\hline Rat index & - & 0.137 & 0.022 \\
Mouse index & 0.137 & - & -0.140 \\
Hedgehog index & 0.022 & -0.140 & - \\
\hline
\end{tabular}




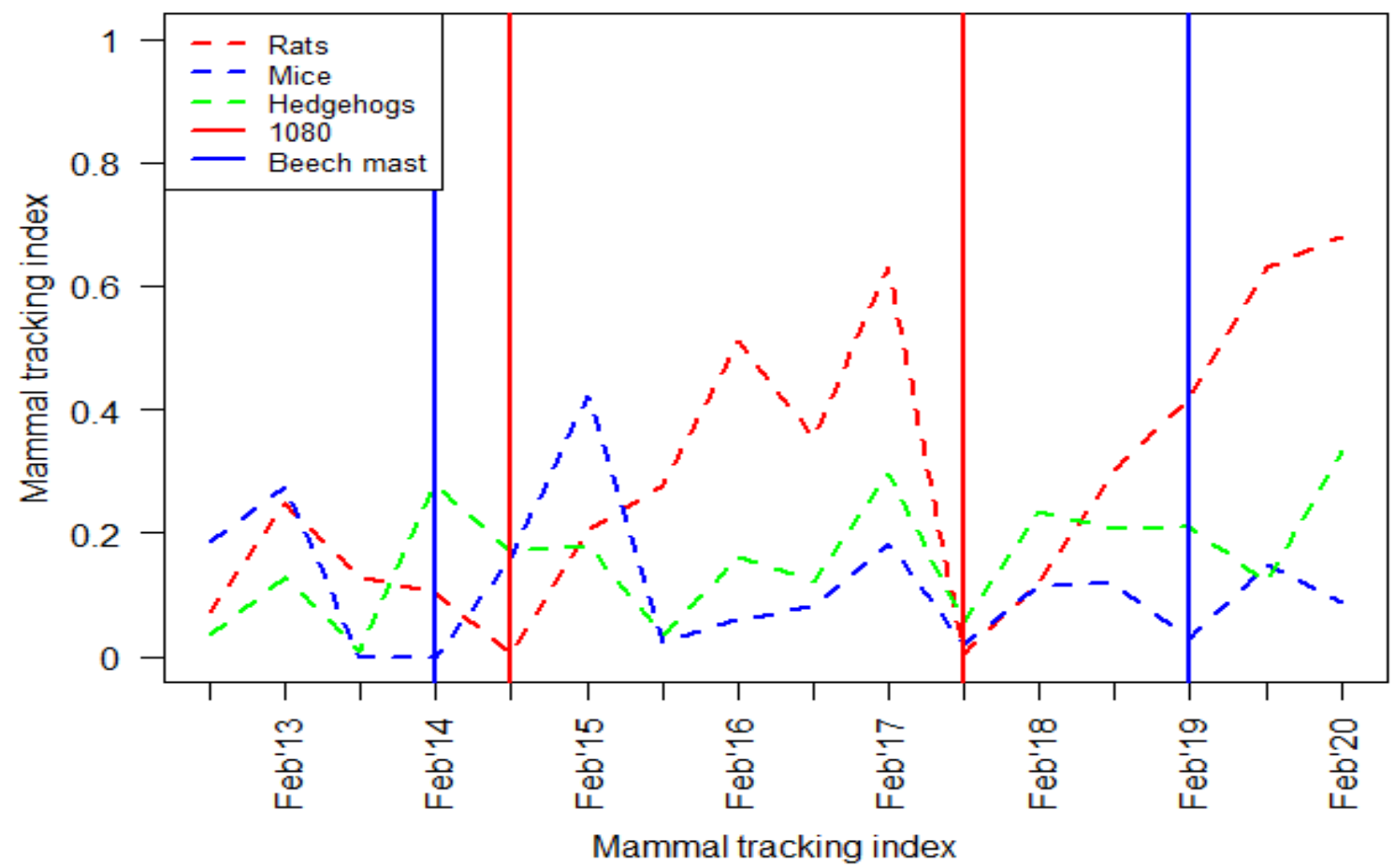

Figure 6.1 Mammal index in the Aorangi forest park including the timing of 1080 pest control operations and beech masting events.

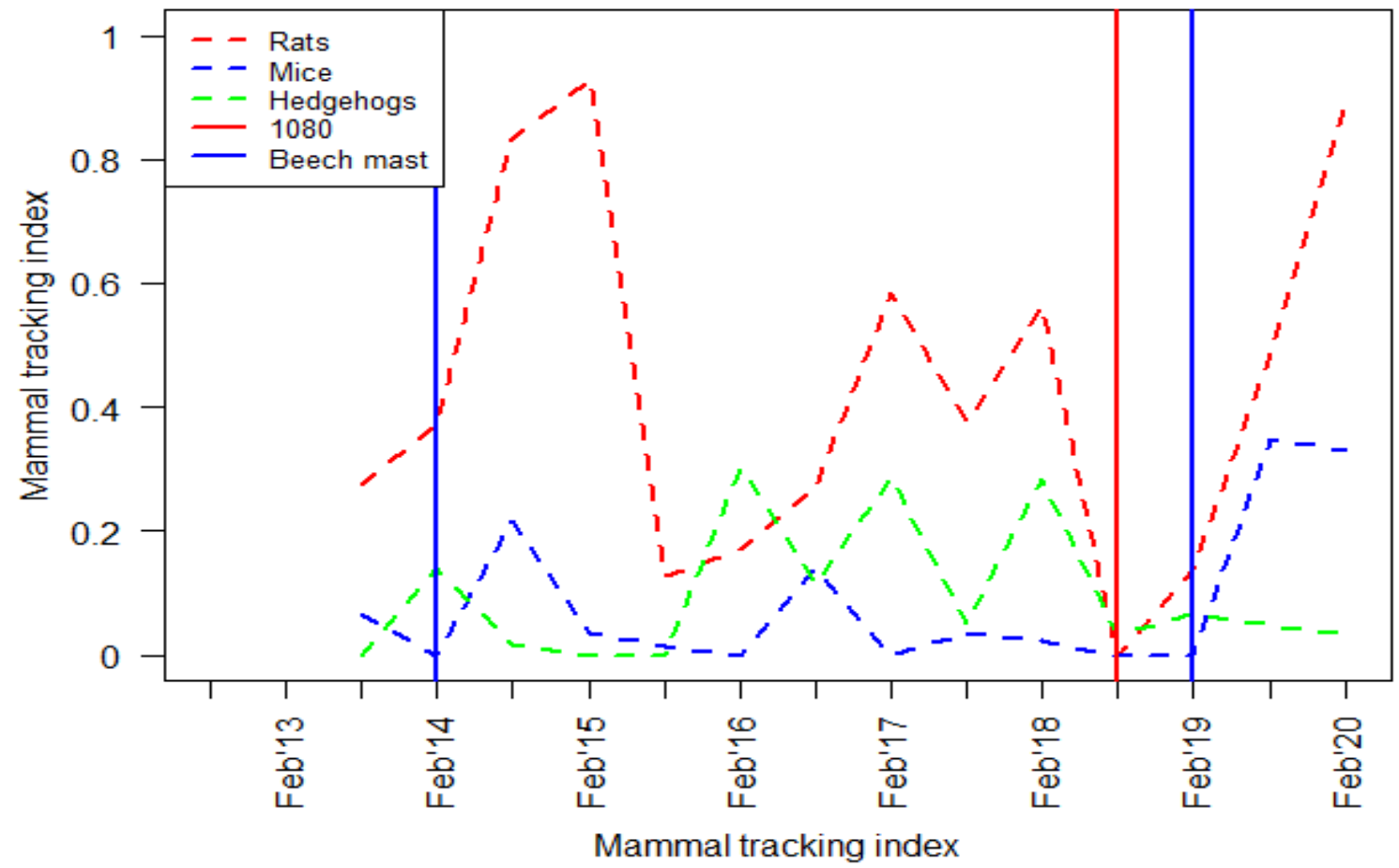

Figure 6.2 Mammal index in the Remutaka forest by season including the timing of 1080 aerial pest control and timing of beech masts. 

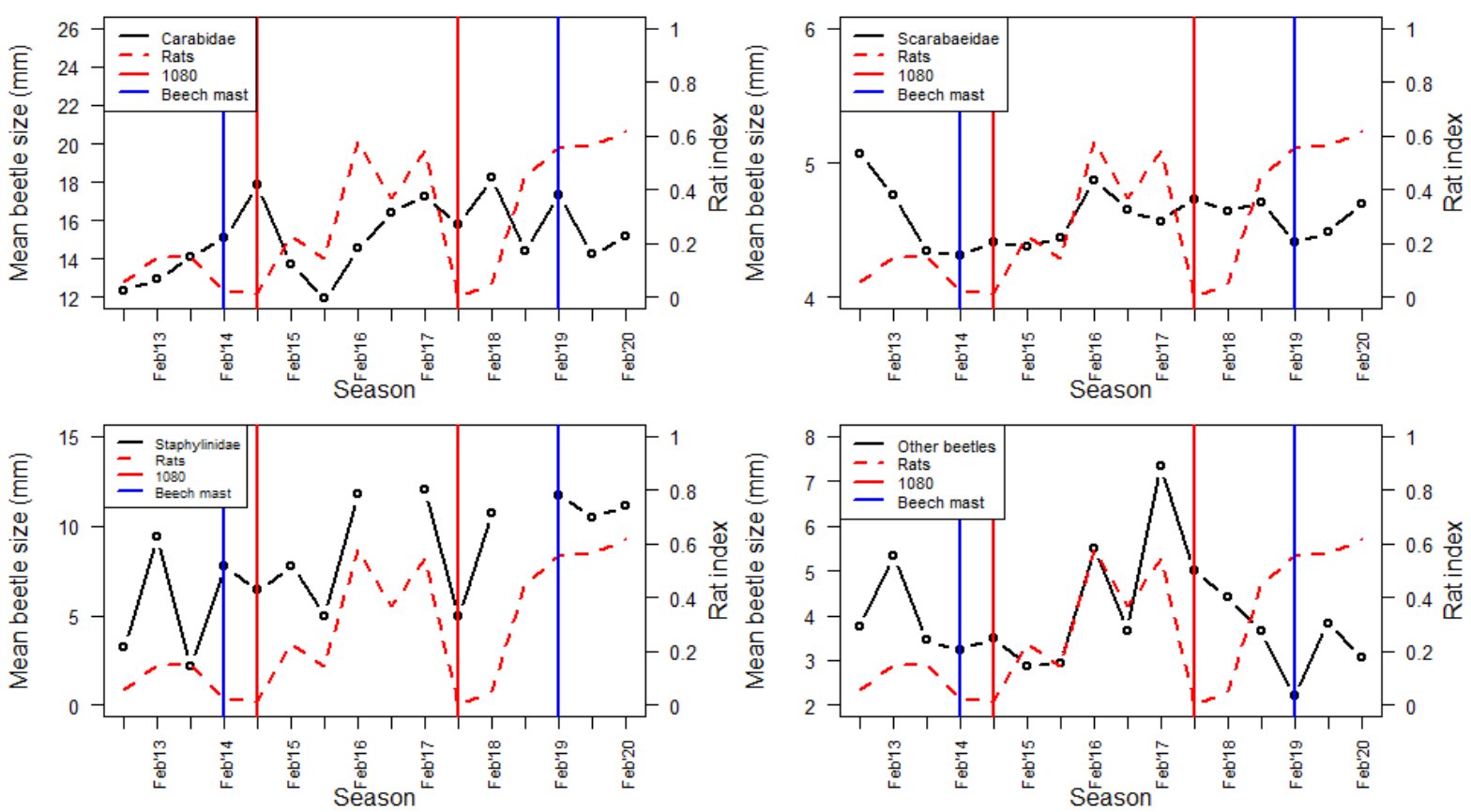

Figure 6.3 Mean beetle size (mm) and rat index in the Aorangi forest park by season including timing of 1080 predator control and beech masts plotted for the subsequent sampling period. No invertebrate sampling occurred in winter (Jun) mammal winter sampling period omitted for ease of plotting. Gaps indicate seasons where no individuals were caught.
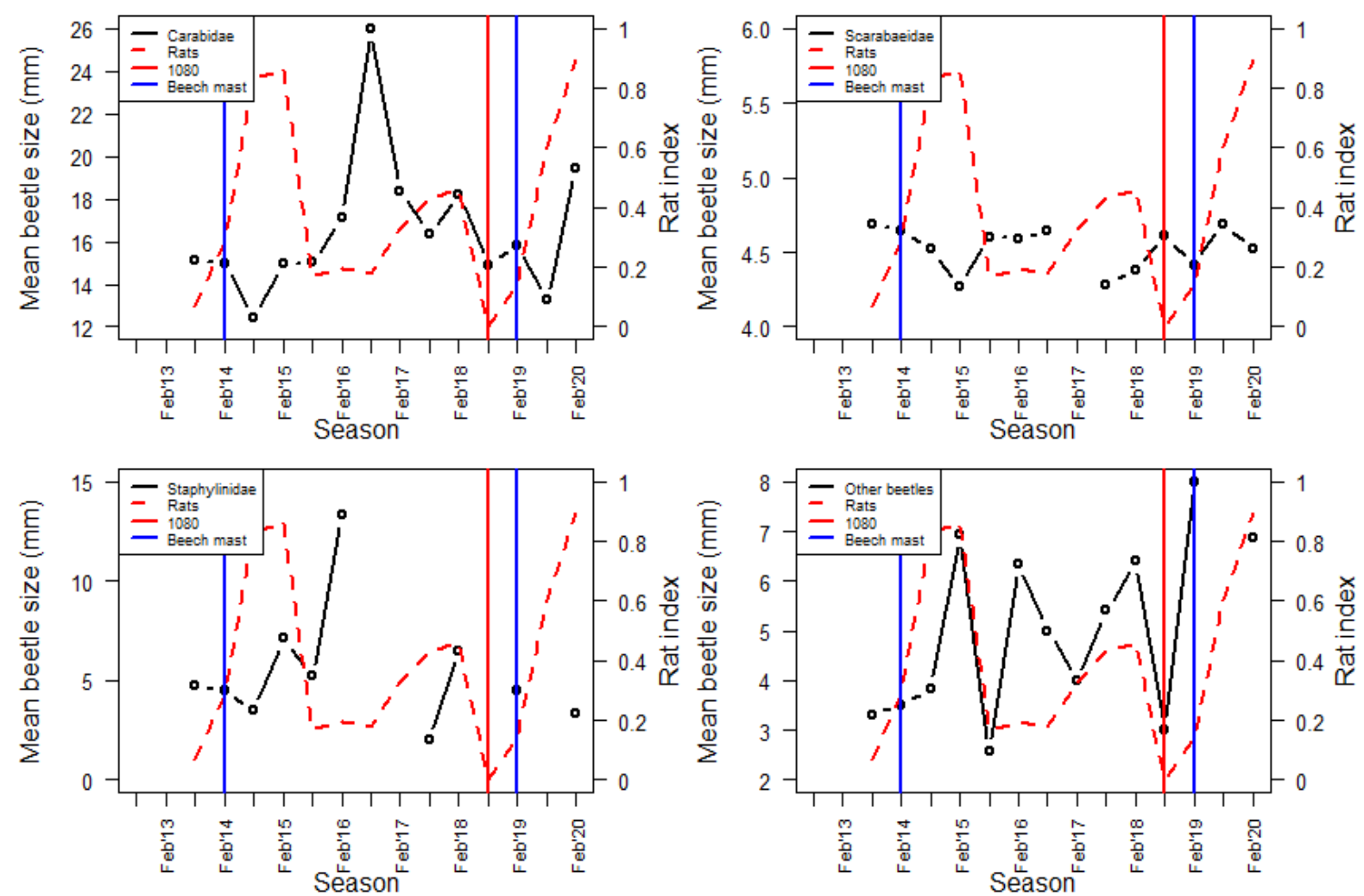

Figure 6.4 Mean beetle size $(\mathrm{mm})$ and rat tracking index in the Remutaka forest park by season including timing of 1080 predator control and beech masts plotted for the subsequent sampling period. No invertebrate sampling occurred in winter (Jun) mammal winter sampling period omitted for ease of plotting. Gaps indicate seasons where no individuals were caught. 

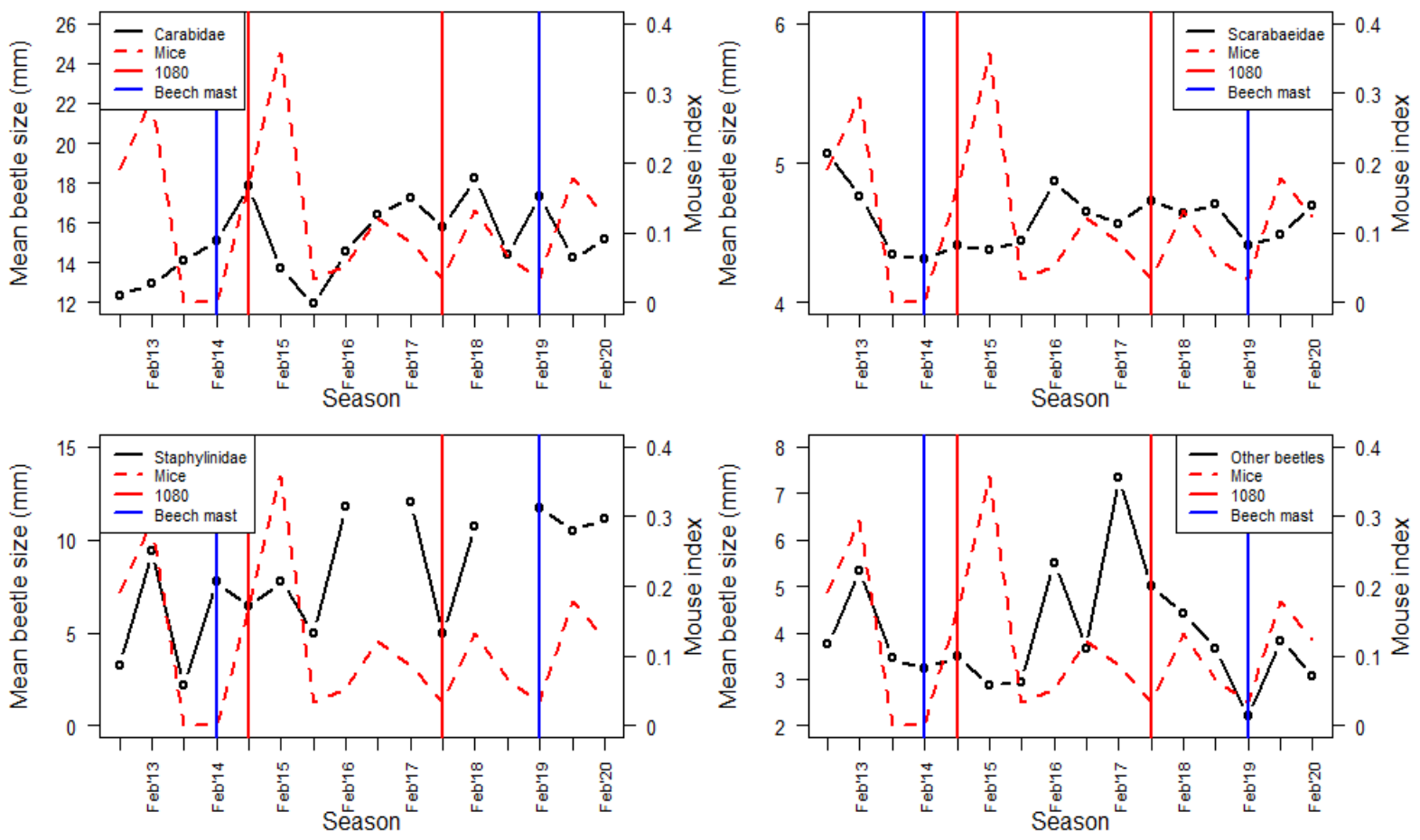

Figure 6.5 Mean beetle size ( $\mathrm{mm}$ ) and mouse index in the Aorangi forest park by season including timing of 1080 predator control and beech masts plotted for the subsequent sampling period. No invertebrate sampling occurred in winter (Jun) mammal winter sampling period omitted for ease of plotting. Gaps indicate seasons where no individuals were caught.
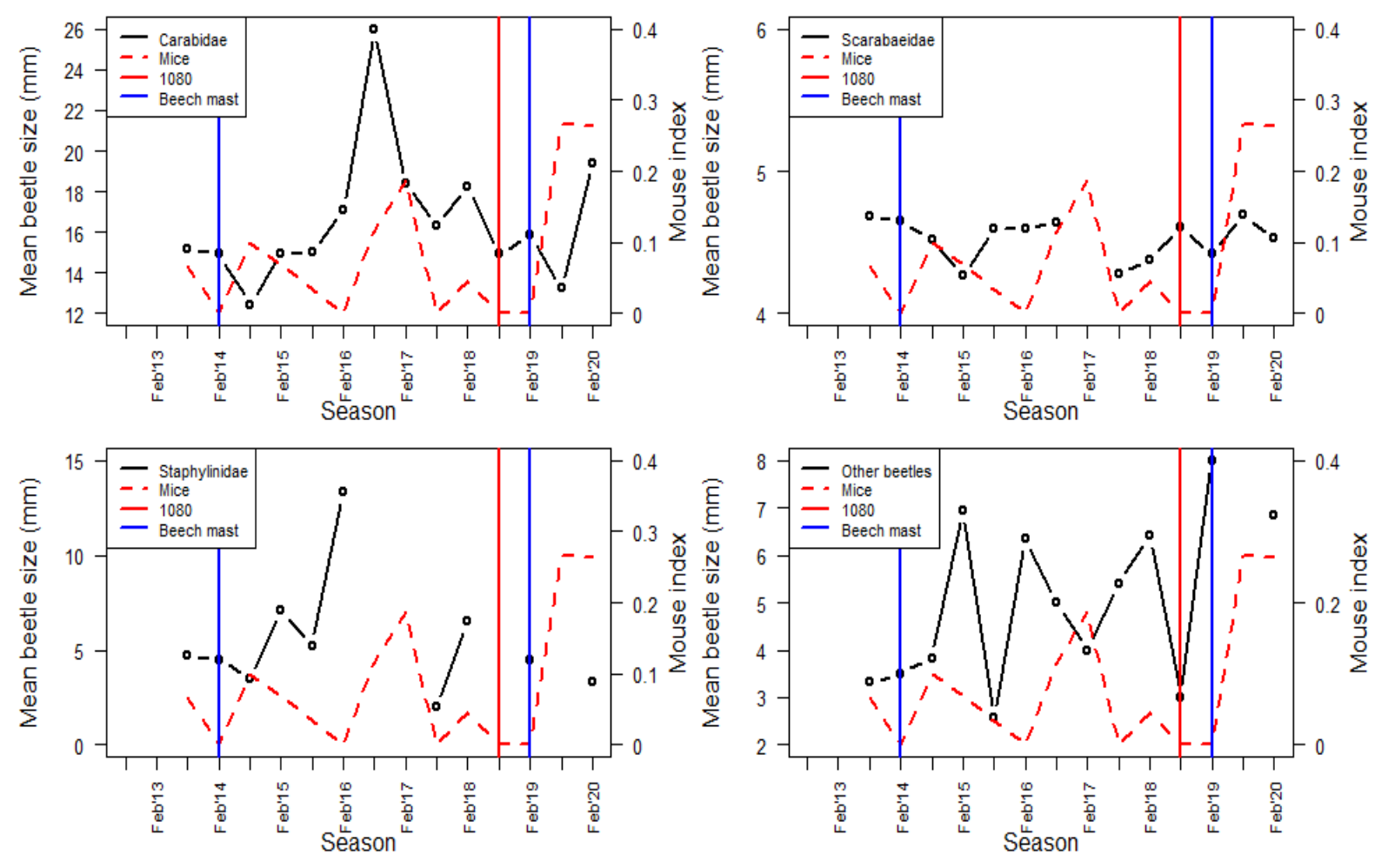

Figure 6.6 Mean beetle size $(\mathrm{mm})$ and mouse index in the Remutaka forest park by season including timing of 1080 predator control and beech masts plotted for the subsequent sampling period. No invertebrate sampling occurred in winter (Jun) mammal winter sampling period omitted for ease of plotting. Gaps indicate seasons where no individuals were caught. 

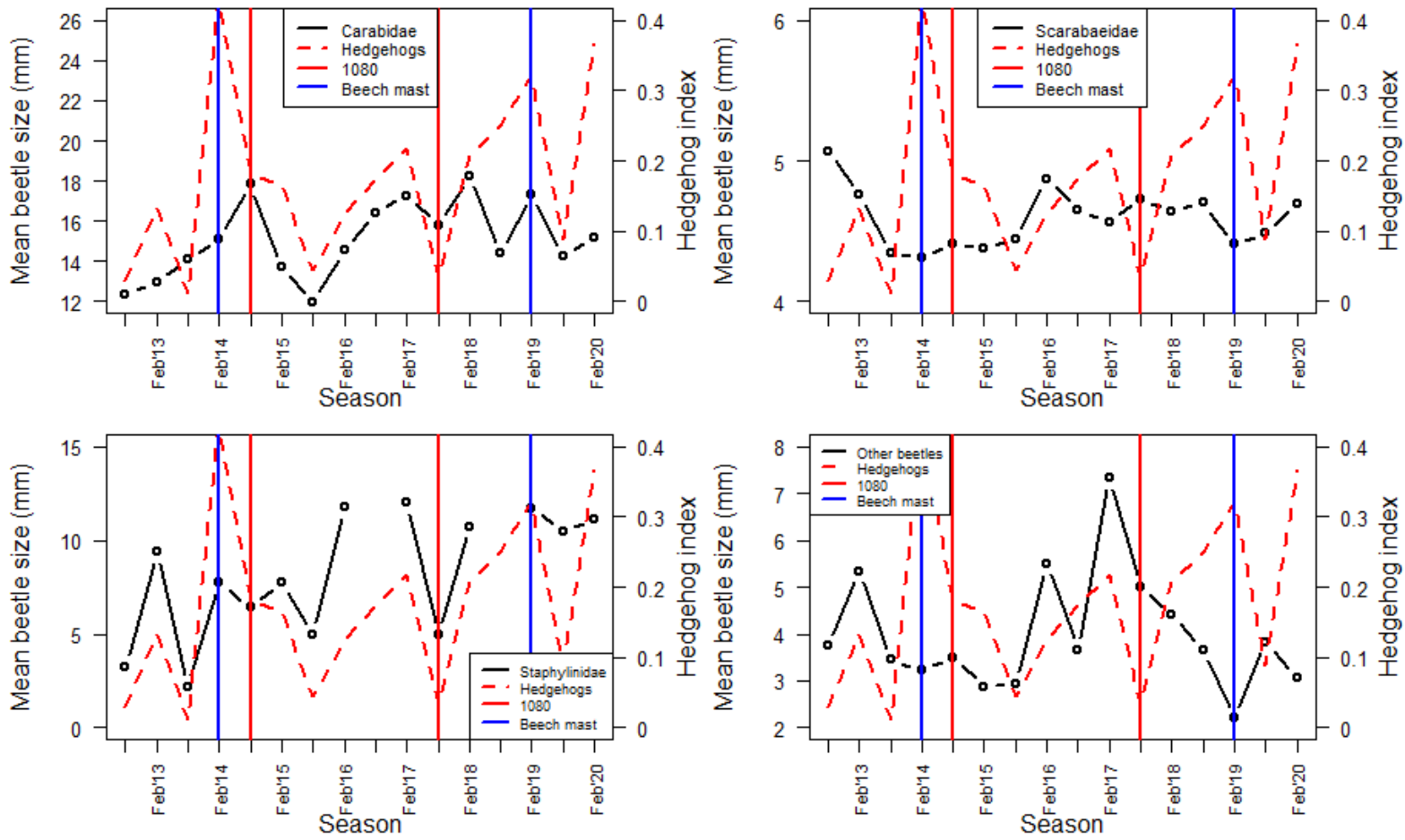

Figure 6.7 Mean beetle size (mm) and hedgehog index by season in the Aorangi forest park by season including timing of 1080 predator control and beech masts plotted for the subsequent sampling period. No invertebrate sampling occurred in winter (Jun) mammal winter sampling period omitted for ease of plotting. Gaps indicate seasons where no individuals were caught.
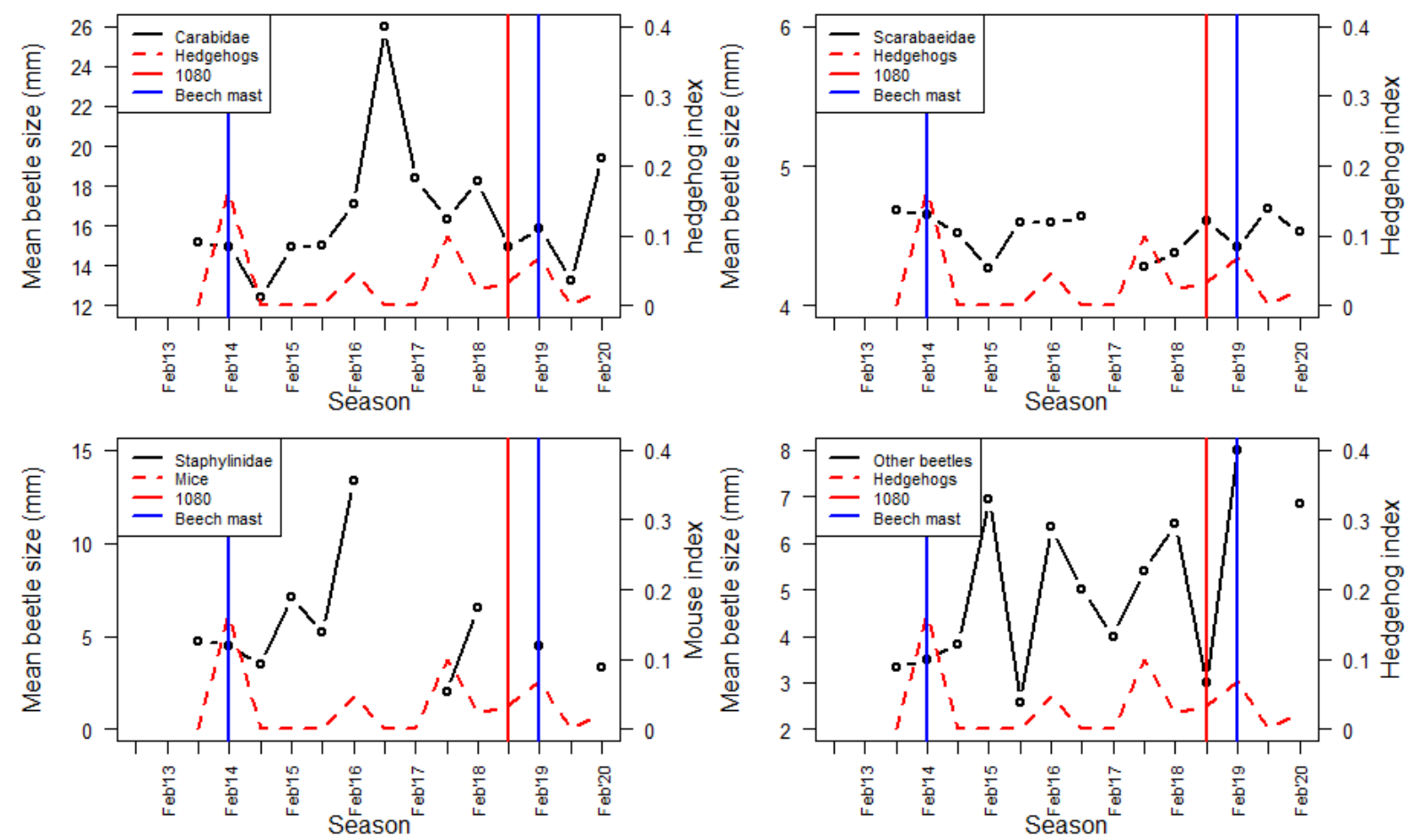

Figure 6.8 Mean beetle size $(\mathrm{mm})$ and hedgehog index by season in the Remutaka forest park, including timing of 1080 predator control and beech masts plotted for the subsequent sampling period. No invertebrate sampling occurred in winter (Jun) mammal winter sampling period omitted for ease of plotting. Gaps indicate seasons where no individuals were caught. 

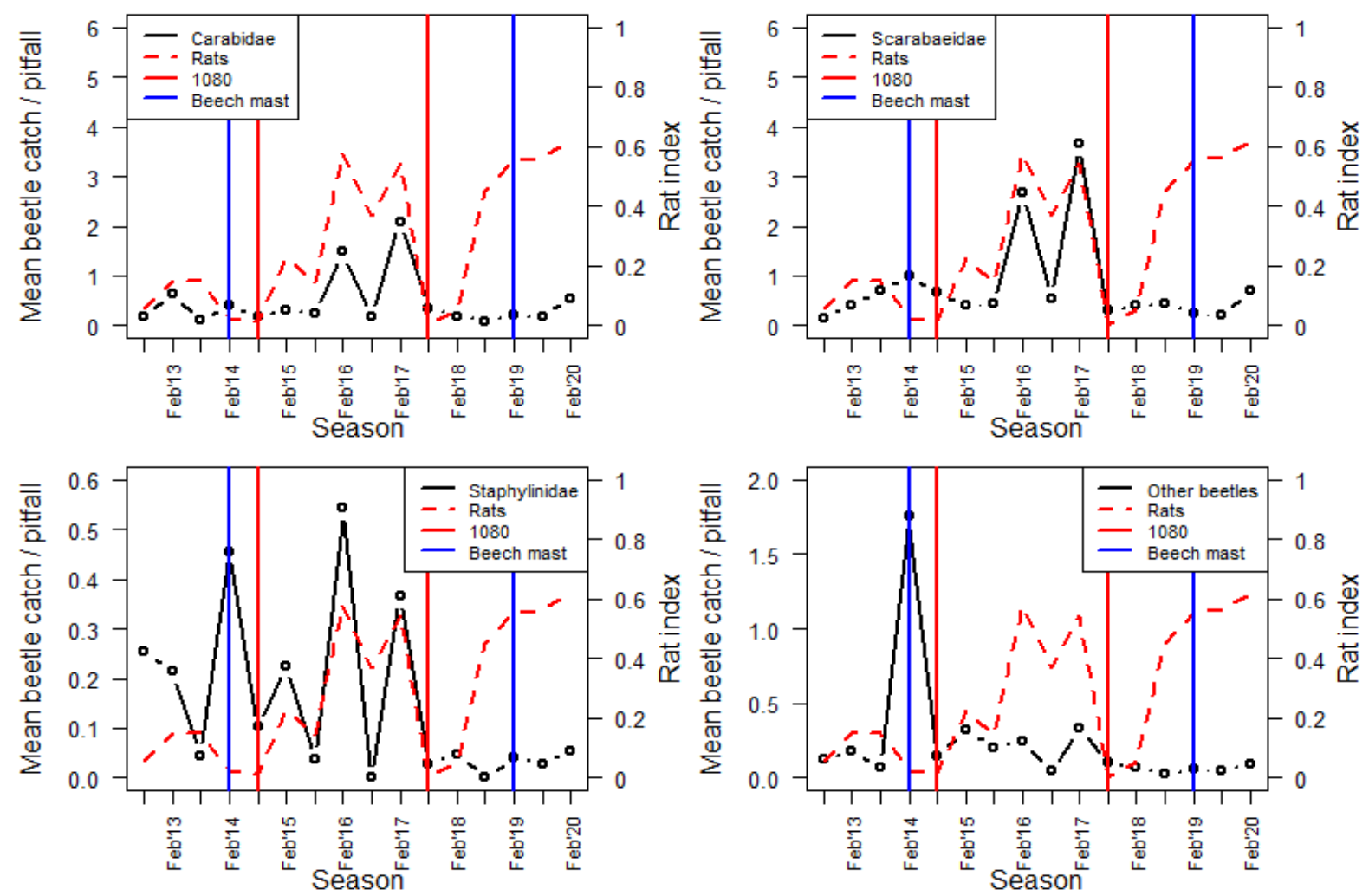

Figure 6.9 Mean beetle catch and rat tracking index in the Aorangi forest park by season.
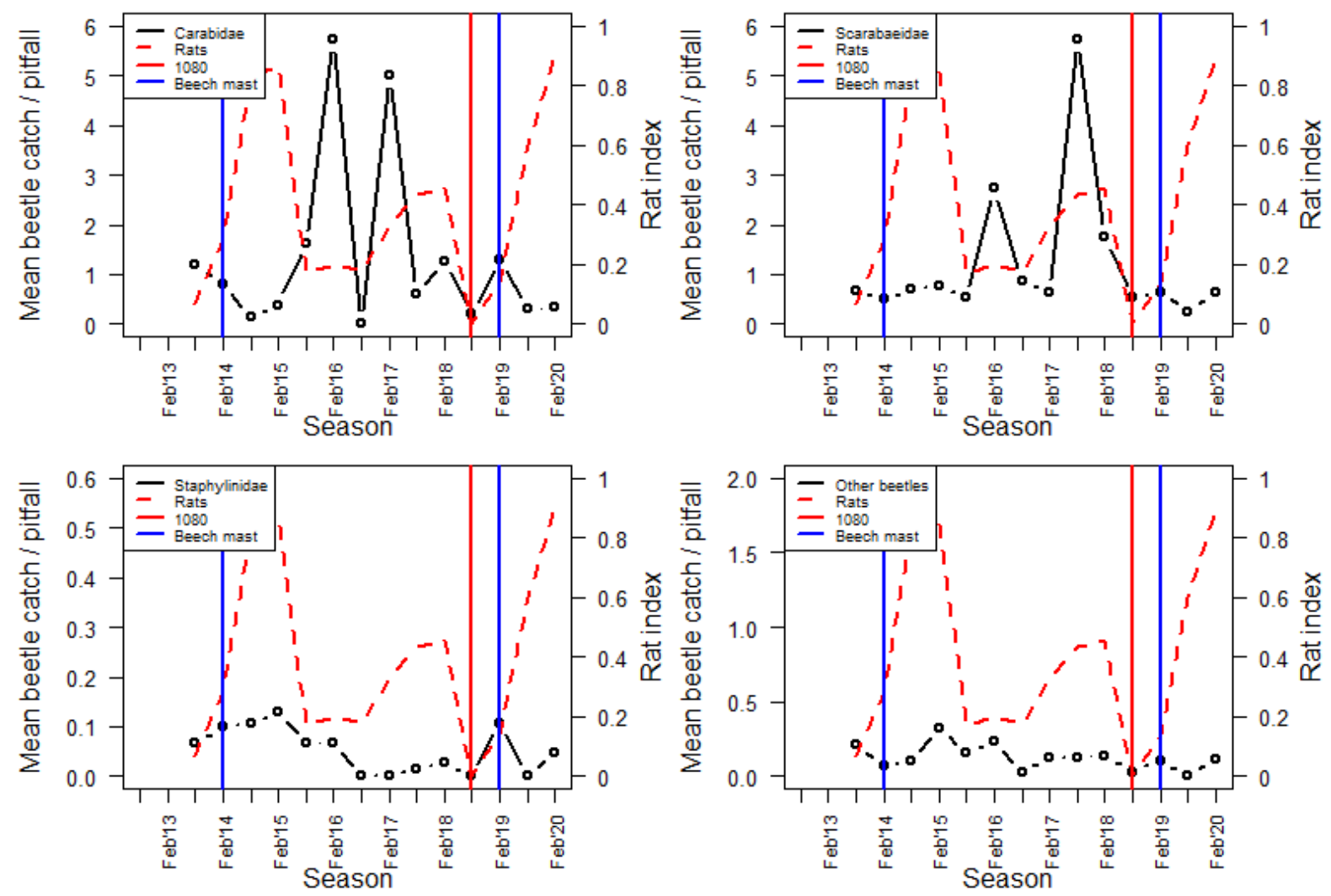

Figure 6.10 Mean beetle catch and rat tracking index in the Remutaka forest park by season. 

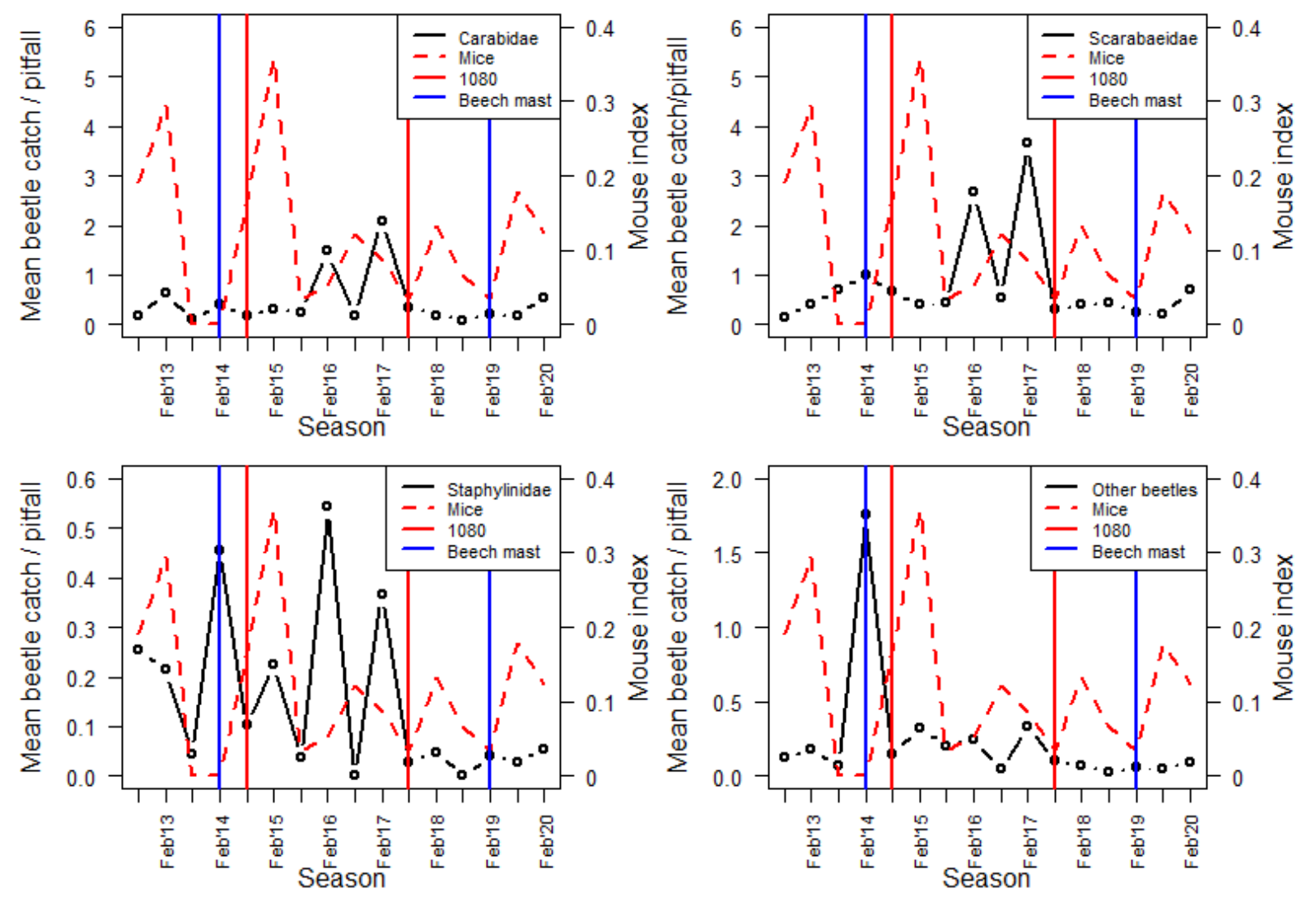

Figure 6.11 Mean beetle catch and mouse index in the Aorangi forest park by season.
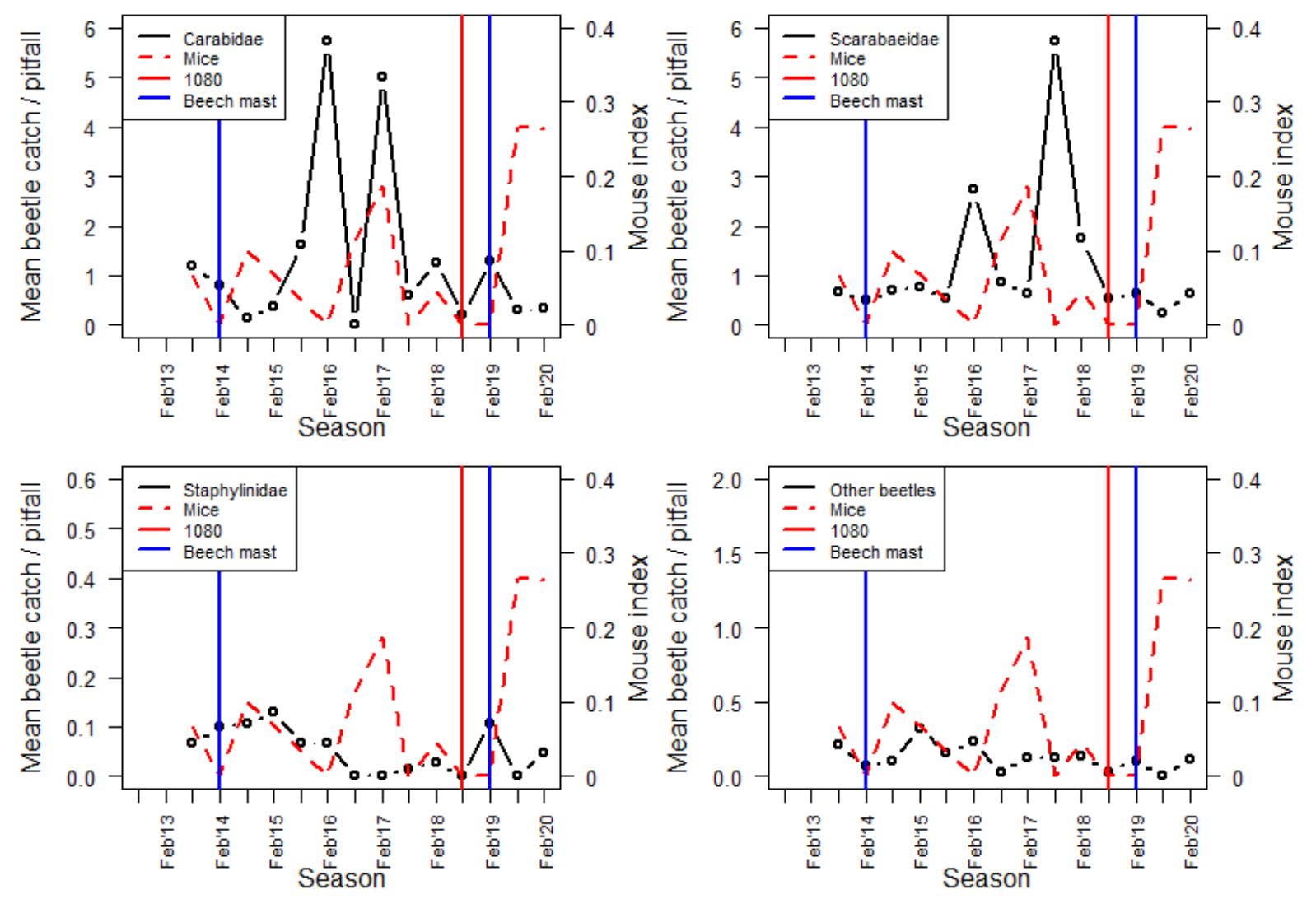

Figure 6.12 Mean beetle catch and mouse index in the Remutaka forest park by season. 

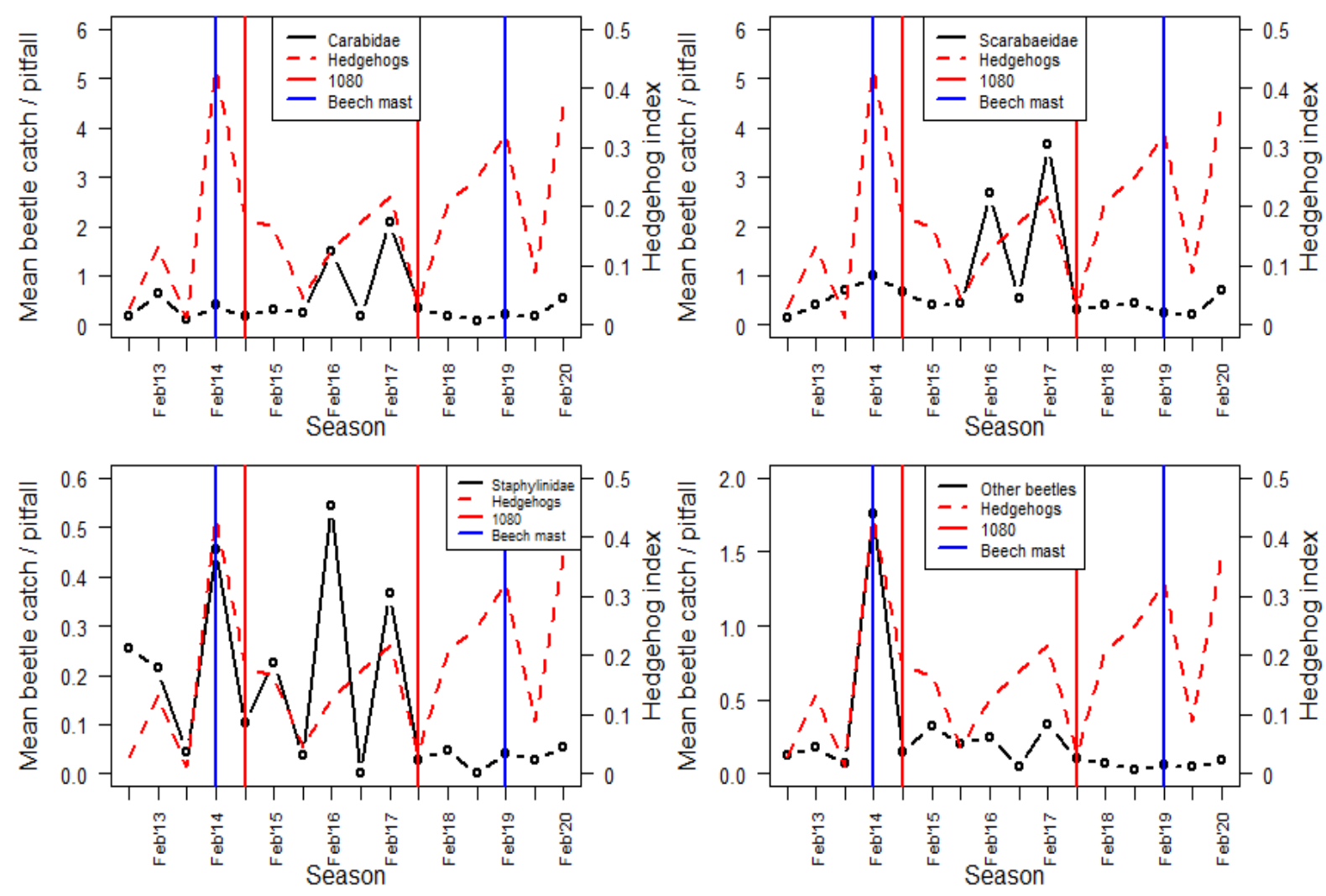

Figure 6.13 Mean beetle catch and hedgehog index by season in the Aorangi forest park.
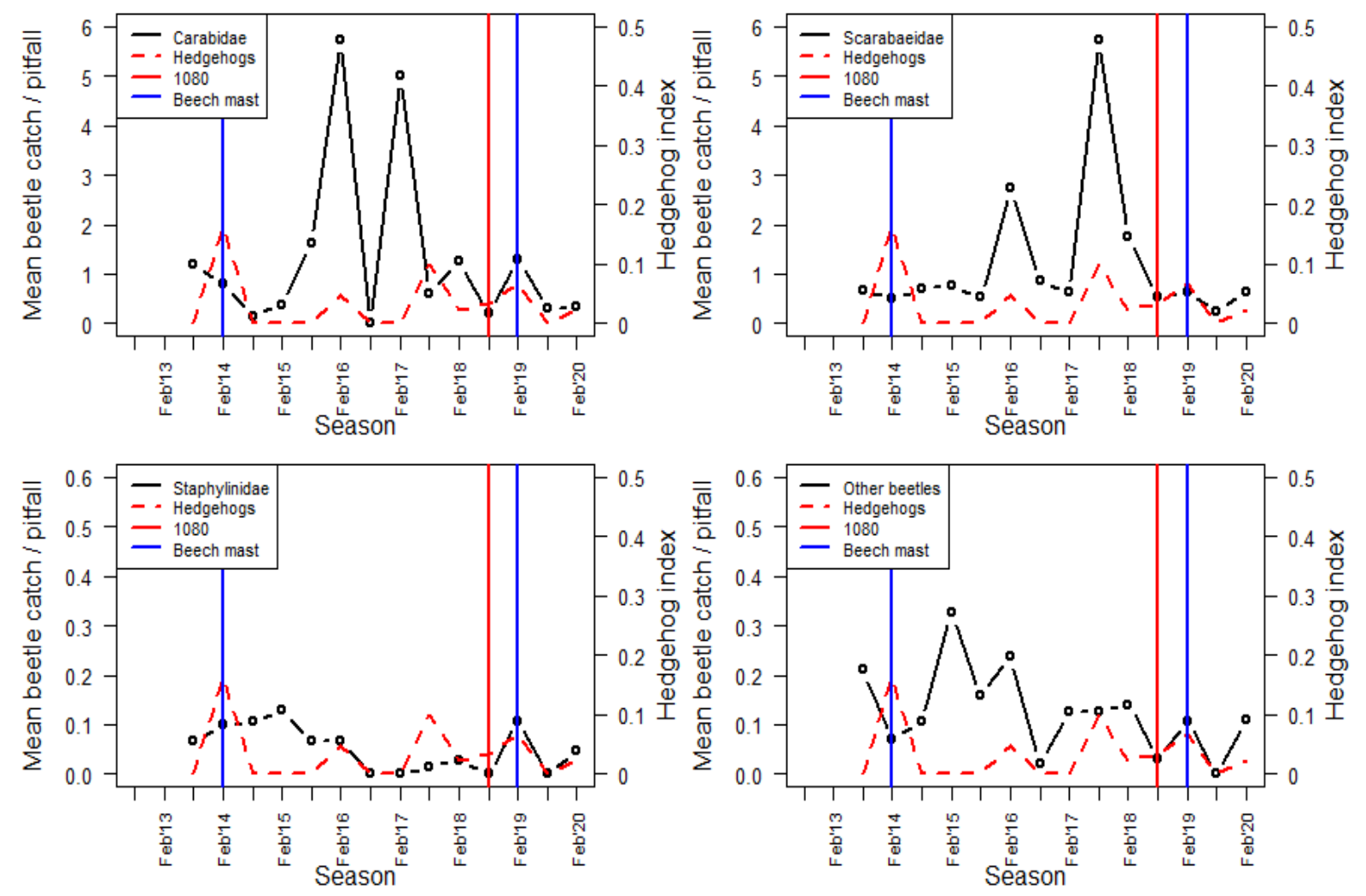

Figure 6.14 Mean beetle catch and hedgehog index by season for the Remutaka forest park. 

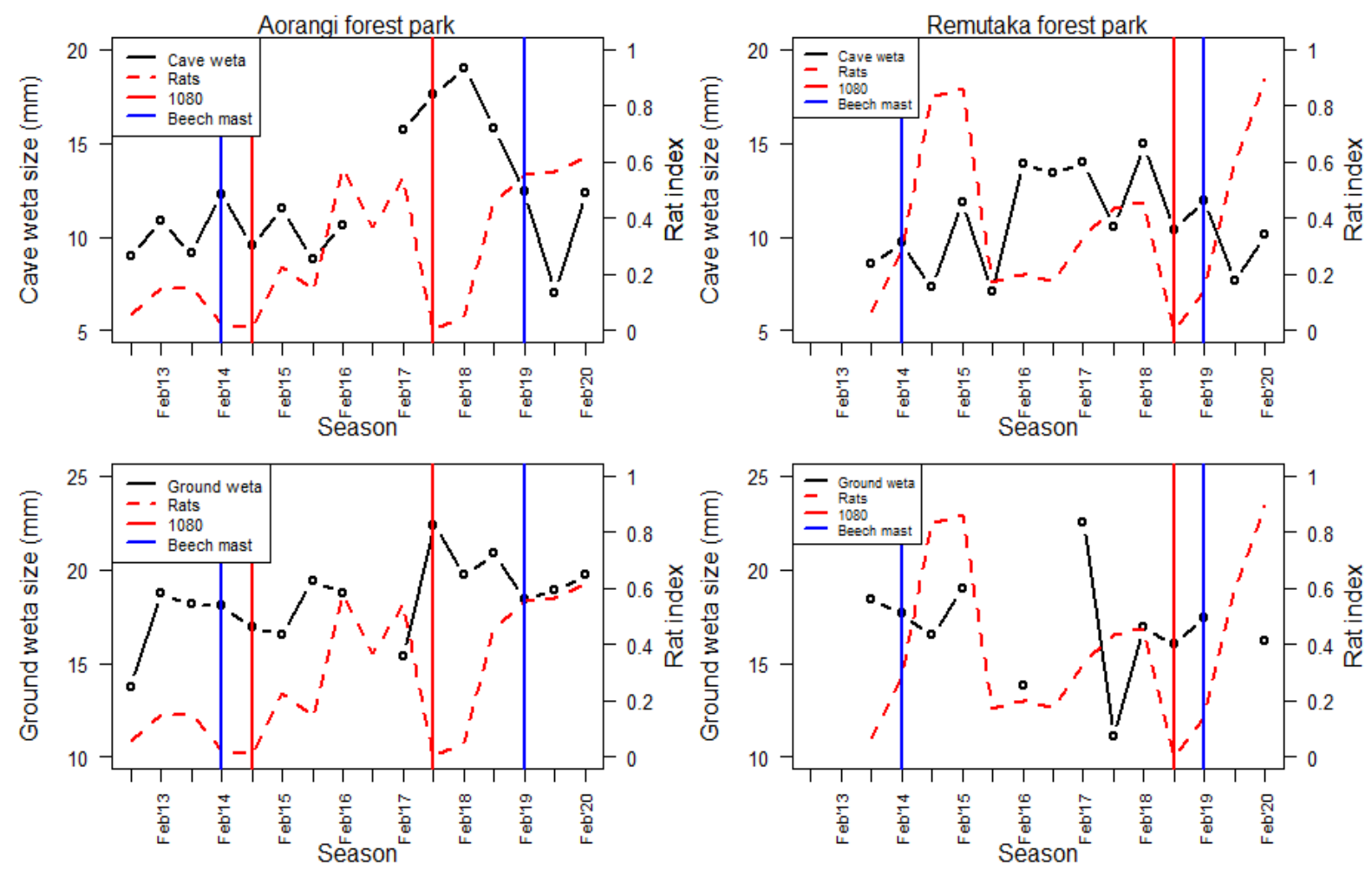

Figure 6.15 Cave and ground wētā size and rat index in the Aorangi (left) and Remutaka (right) forest parks by season.
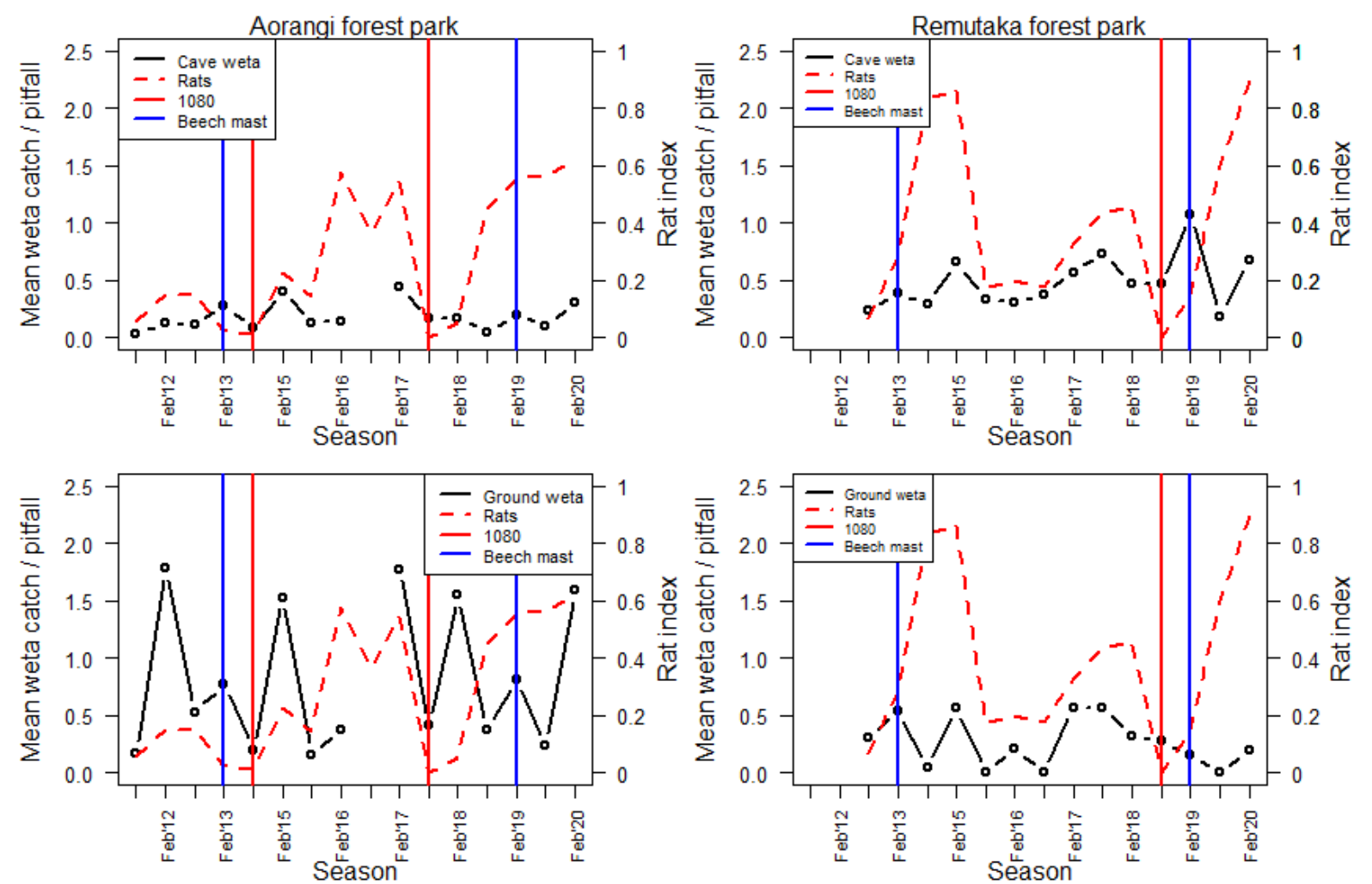

Figure 6.16 Wētā catch rates and rat index for cave (top row) and ground wētā (bottom row) in the Aorangi (left column) and Remutaka (right column) forest parks by season. 

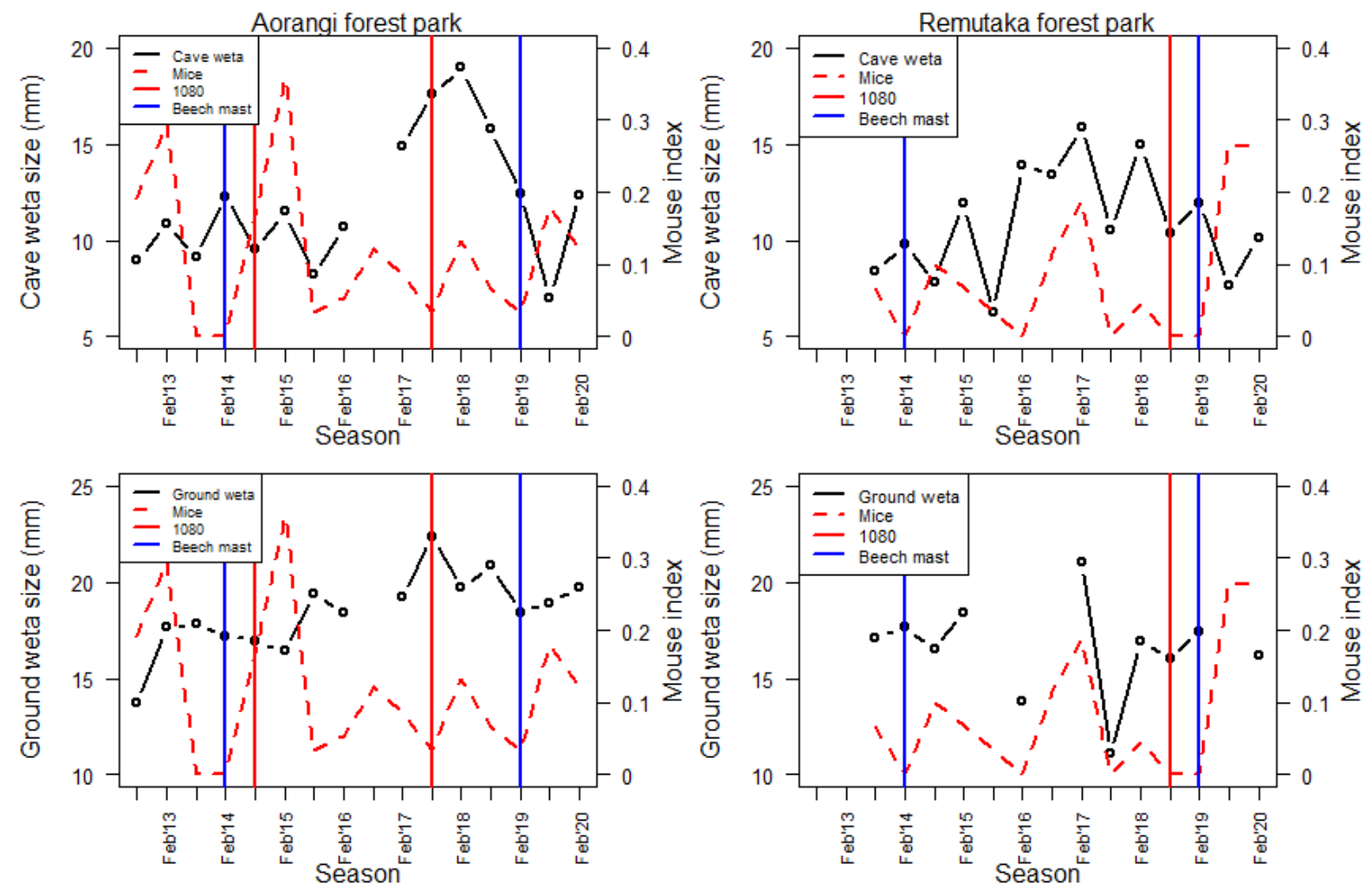

Figure 6.17 Cave (top row) and ground (bottom row) wētā size and mouse index in the Aorangi (left) and Remutaka (right) forest parks by season.
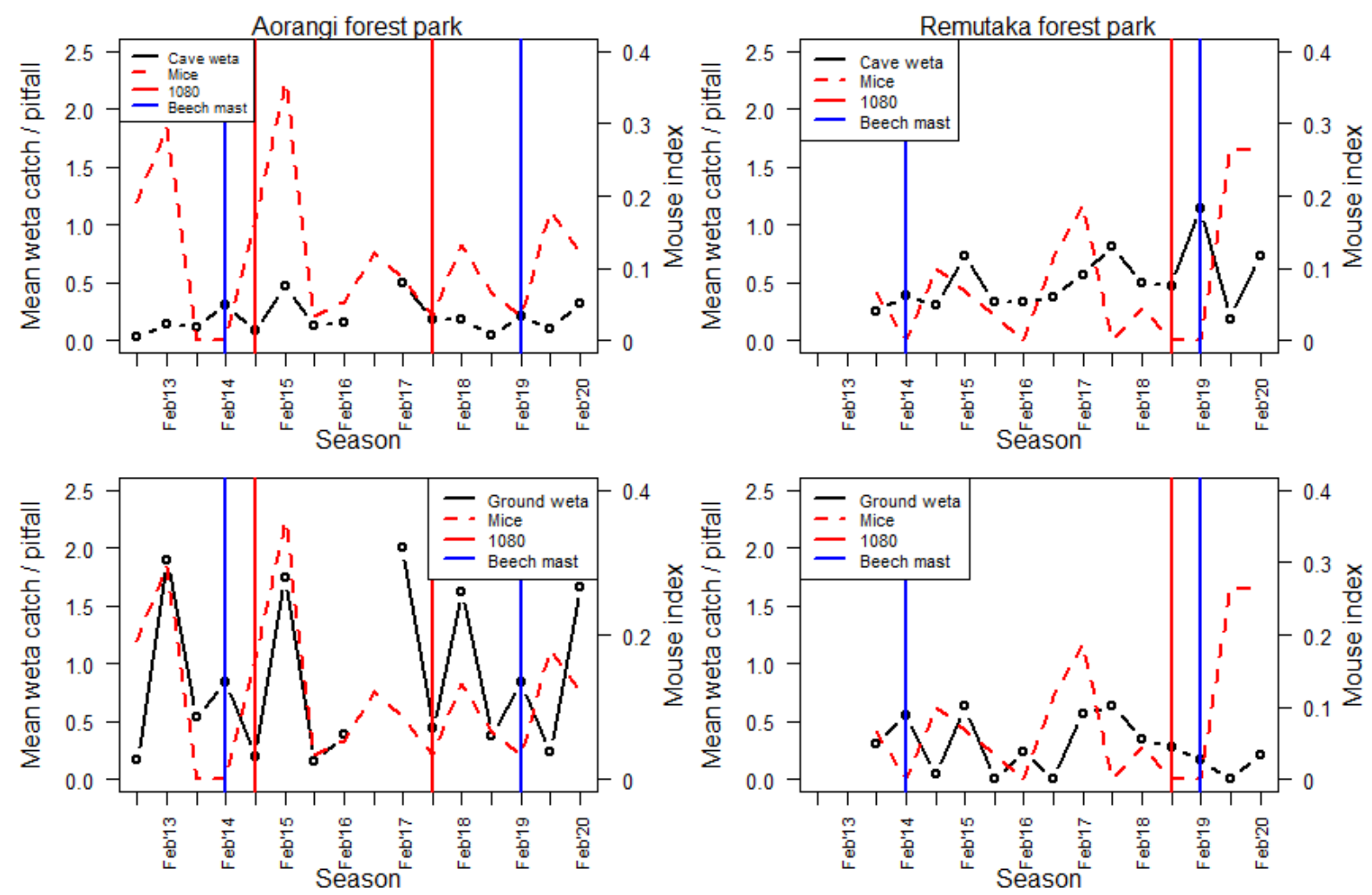

Figure 6.18 Wètā catch and mouse index for cave (top row) and ground wētā (bottom row) in the Aorangi (left column) and Remutaka (right column) forest parks by season. 

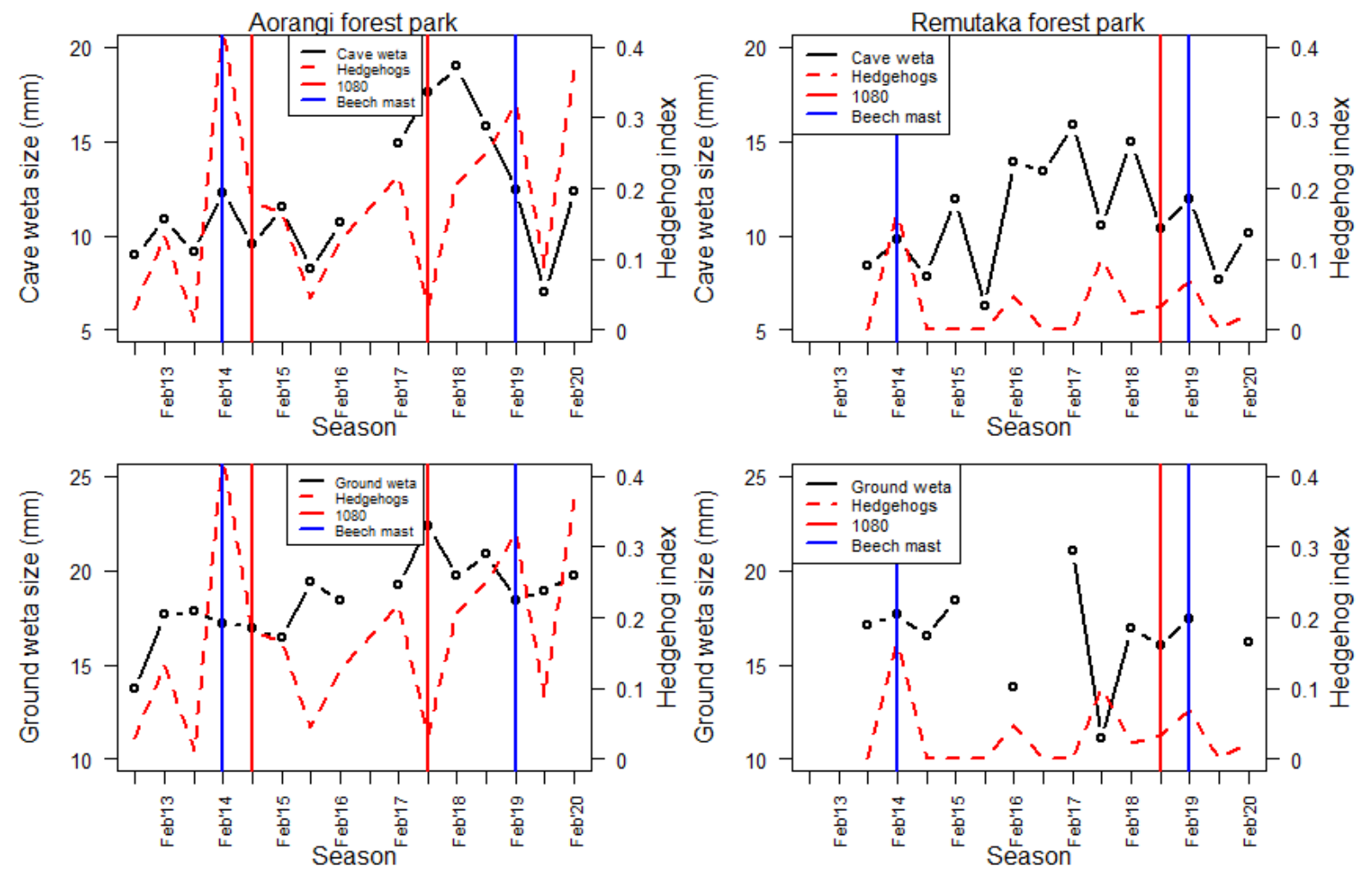

Figure 6.19 Wētā size (mm) and hedgehog index for cave (top row) and ground wētā (bottom row) in the Aorangi (left column) and Remutaka (right column) forest parks by season.
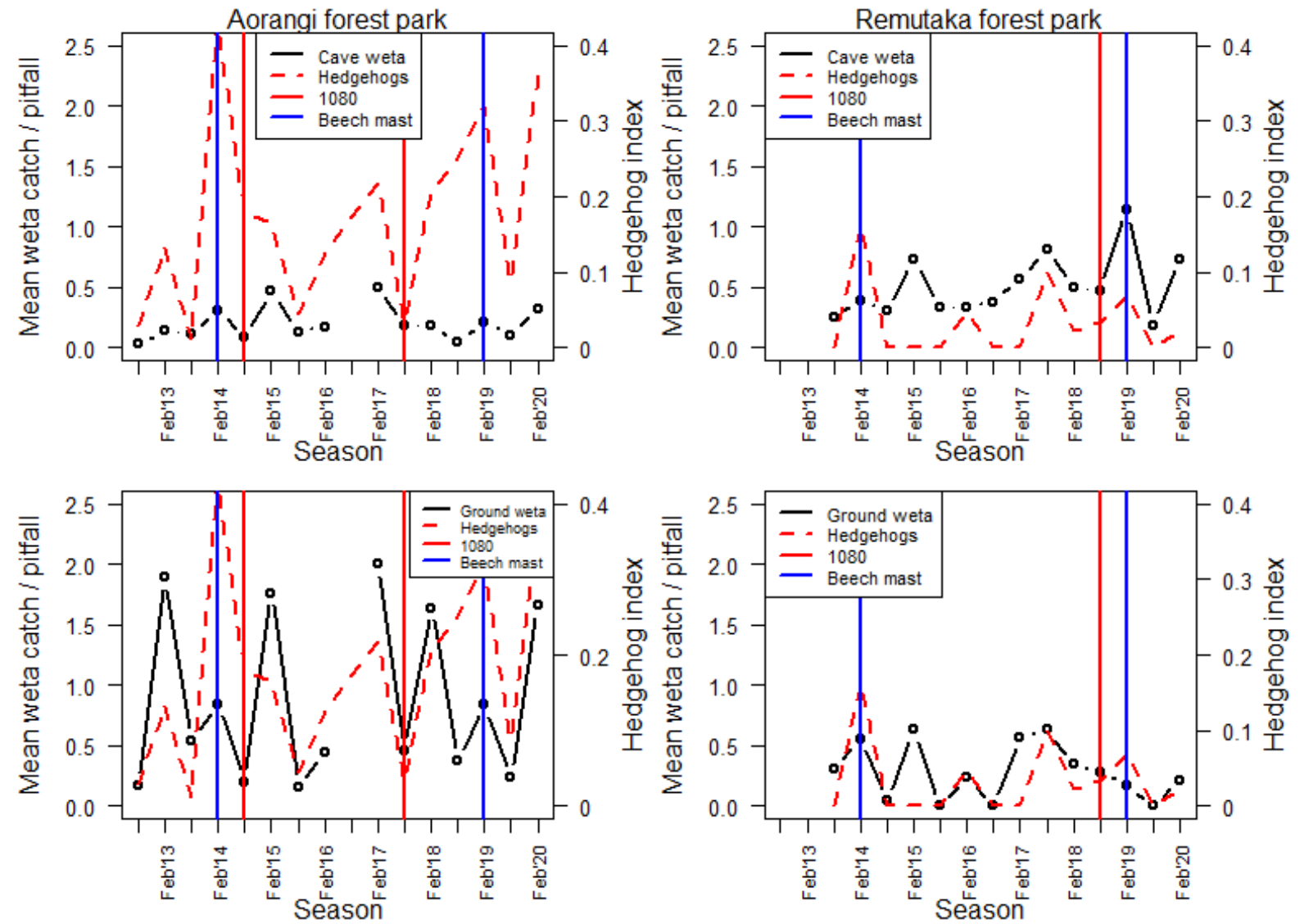

Figure 6.20 Wētā catch and hedgehog index for cave (top row) and ground wētā (bottom row) in the Aorangi (left column) and Remutaka (right column) forest parks by season. 

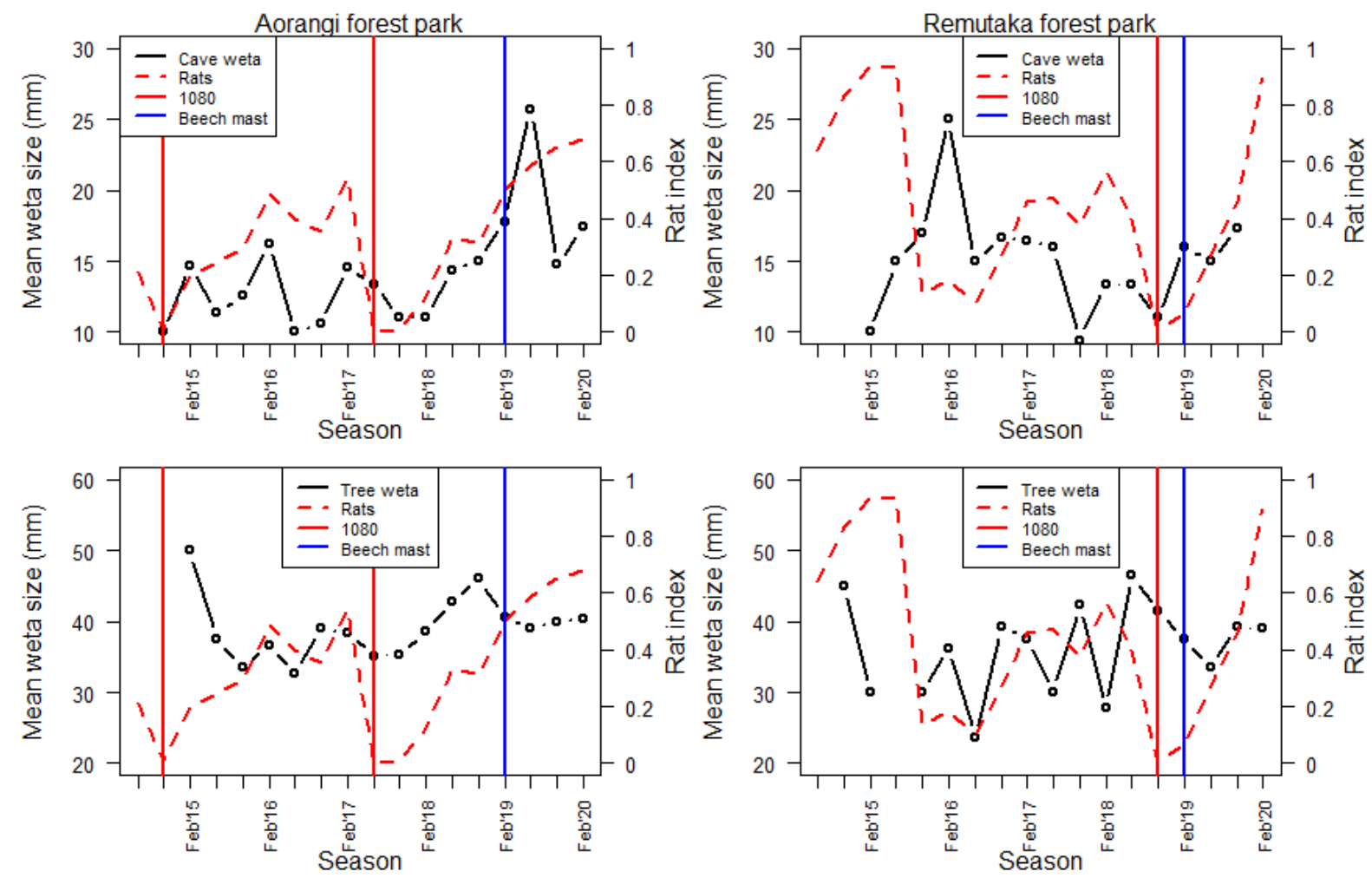

Figure 6.21 Cave (top row) and tree (bottom row) wètā size and rat index in the Aorangi (left coumn) and Remutaka (right column) forest parks by season.
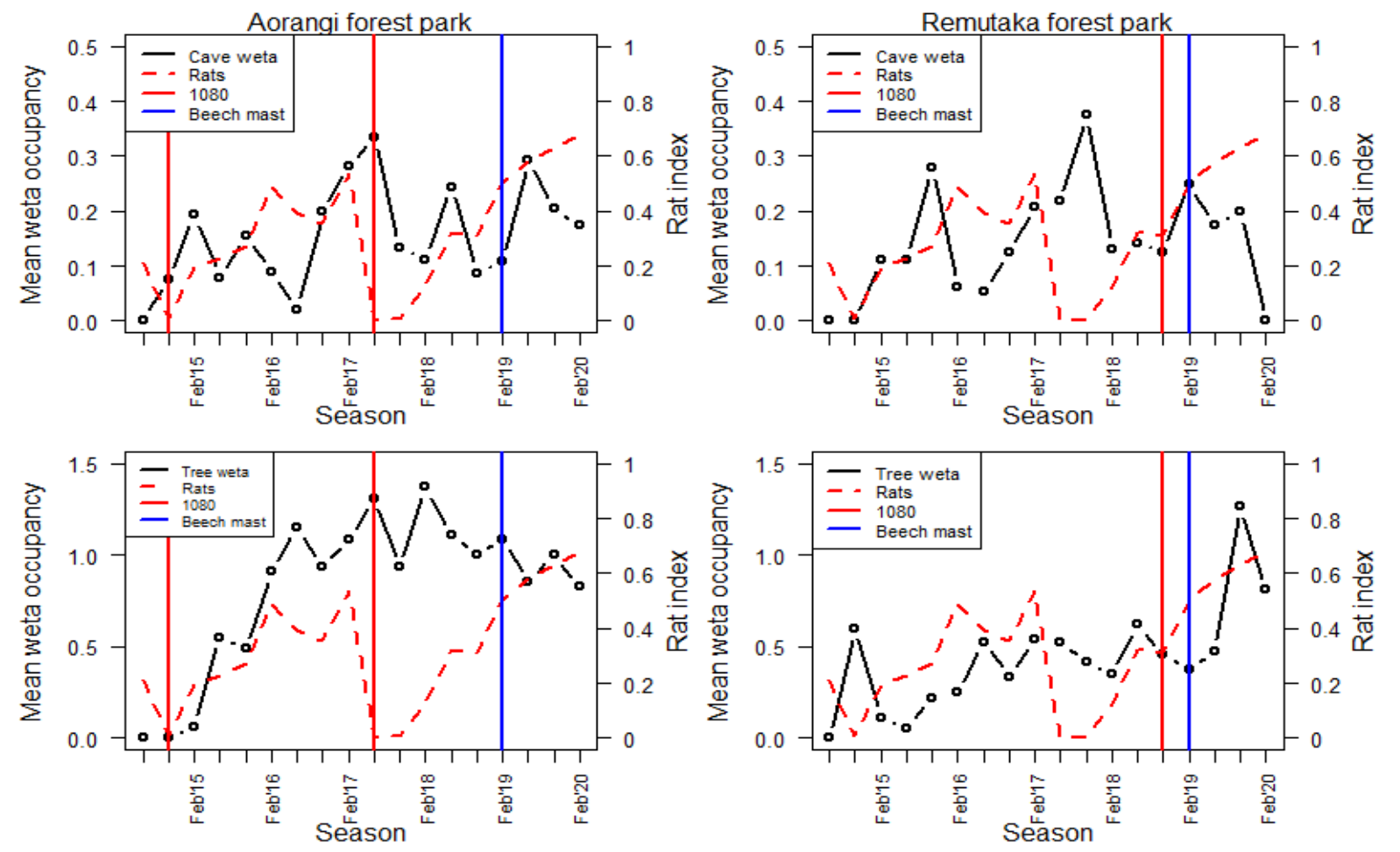

Figure 6.22 Cave (top row) and tree (bottom row) wētā occupancy rate and rat index in the Aorangi (left column) and Remutaka (right colum) forest parks. 

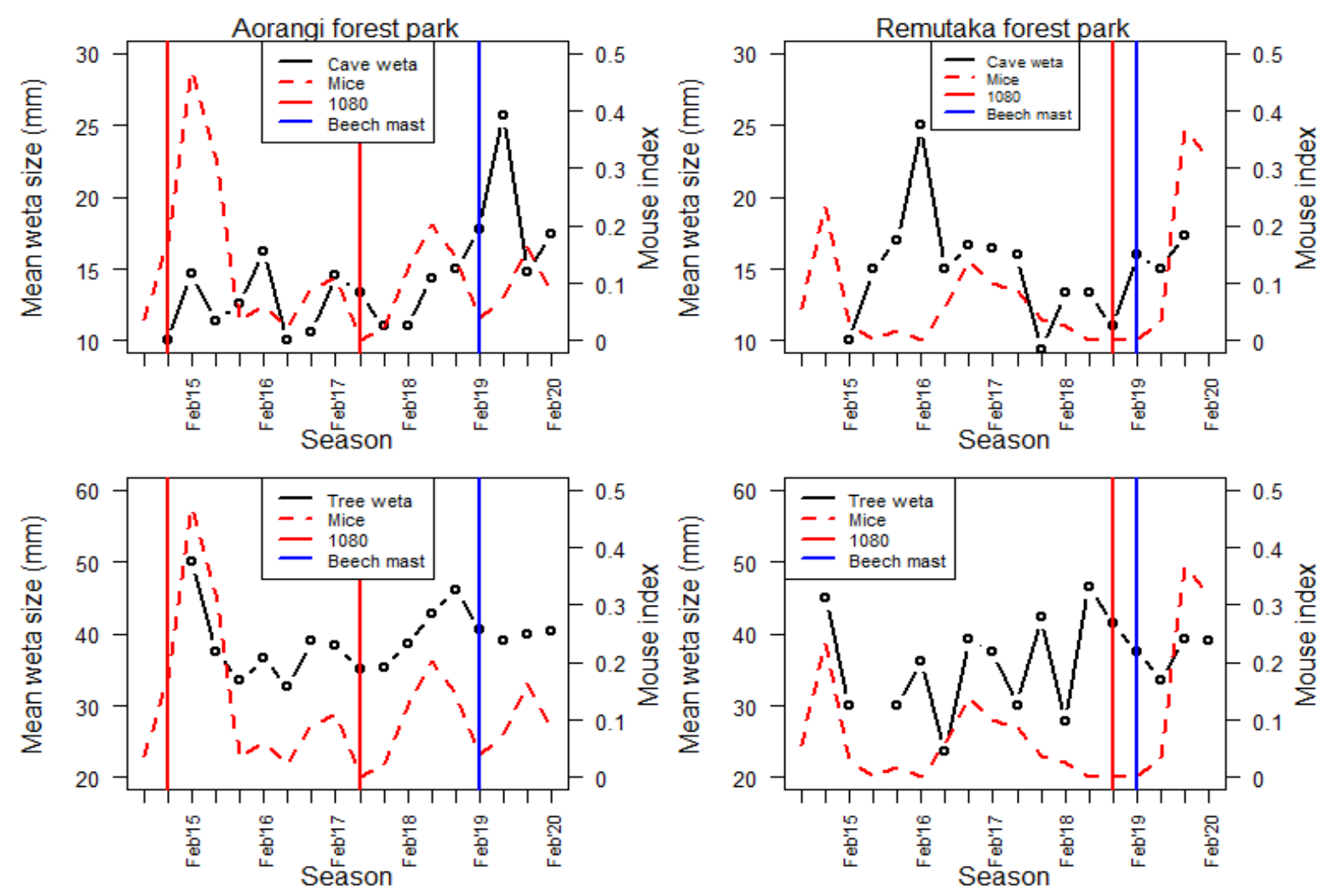

Figure 6.23 Mean cave (top row) and tree (bottom row) wētā size and mouse index in the Aorangi (left) and Remutaka (right) forest park.
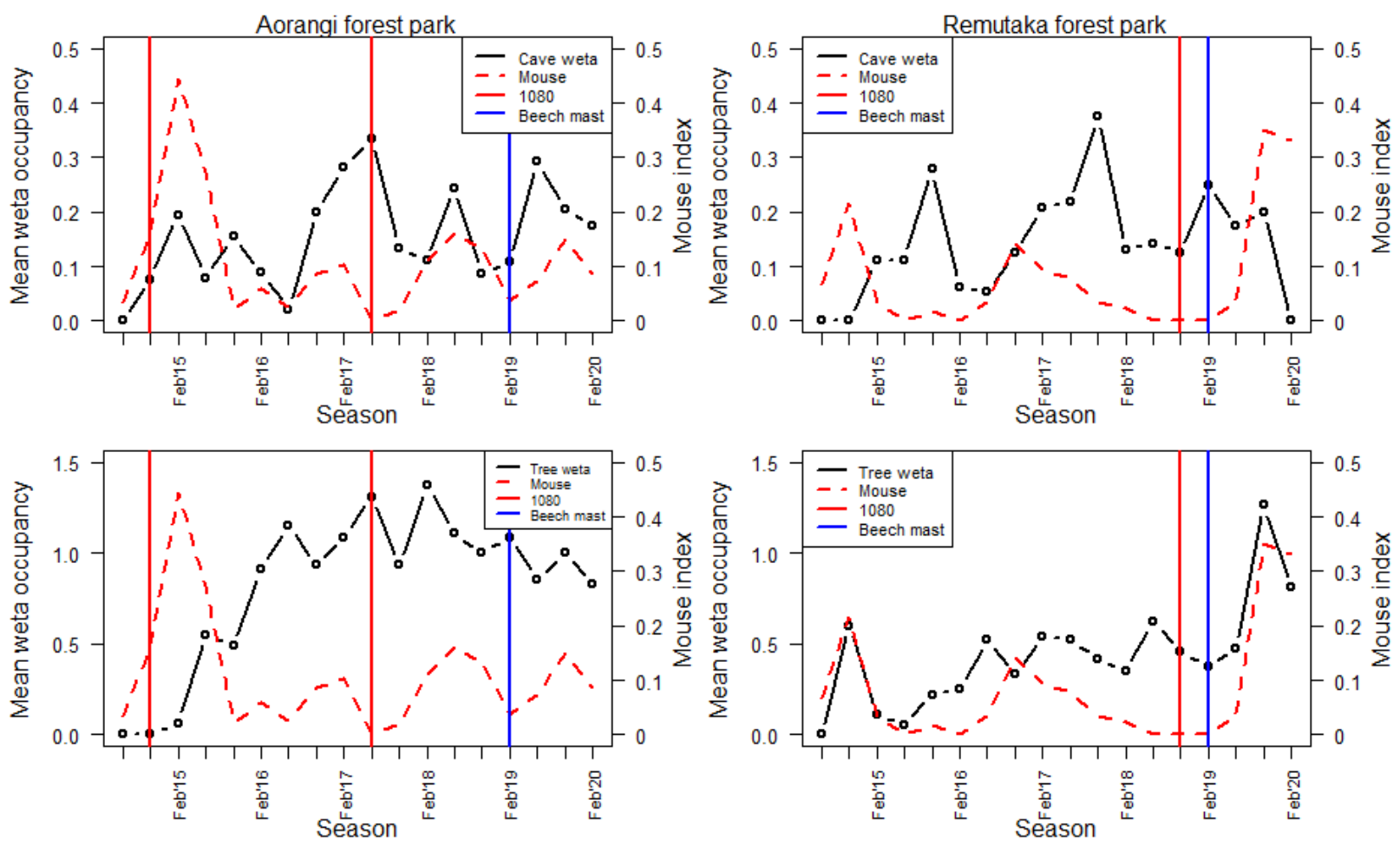

Figure 6.24 Mean cave (top row) and tree (bottom row) wētā occupancy rate and mouse index in the Aorangi (left column) and Remutaka (right column) forest parks. 

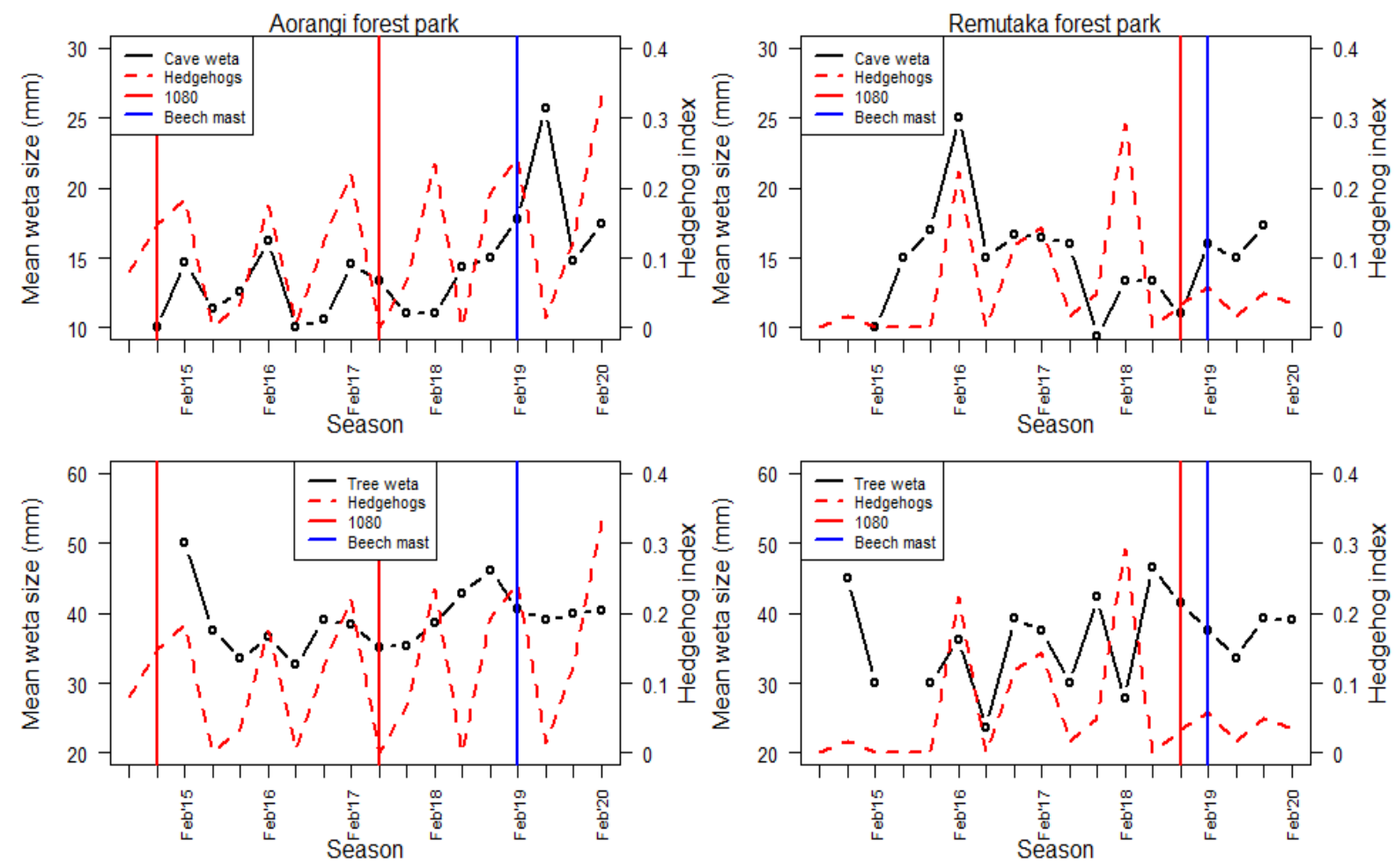

Figure 6.25 Mean cave (top row) and tree (bottom row) wētā size and hedgehog index in the Aorangi (left column) and Remutaka (right column) forest parks.
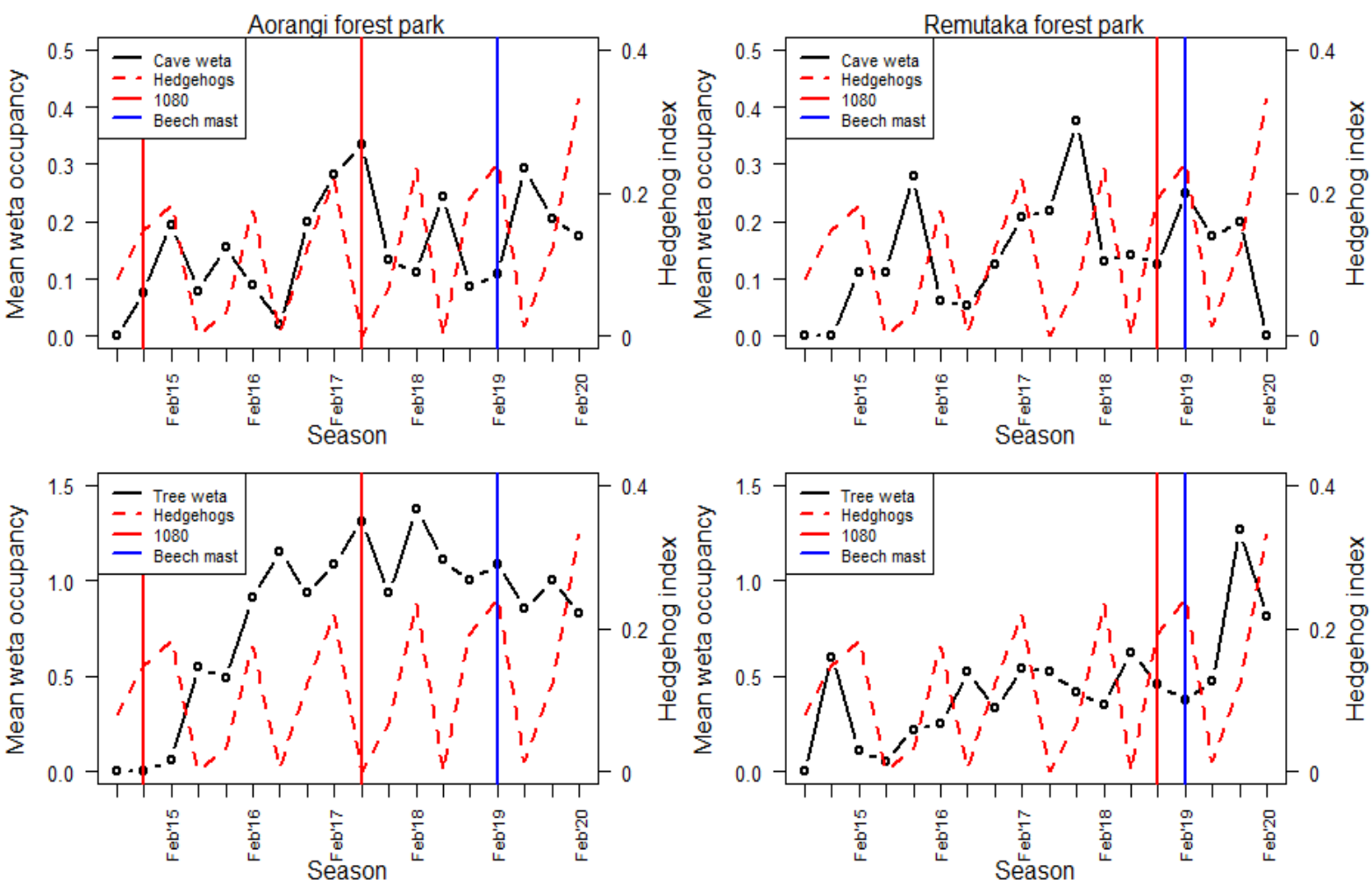

Figure 6.26 Mean cave (top row) and tree (bottom row) wētā occupancy in the Aorangi (left column) and Remutaka (right column) forest parks. 